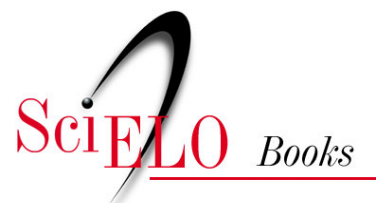

\title{
Saúde e doença
}

um olhar antropológico

\section{Paulo Cesar Alves}

Maria Cecília de Souza Minayo

(orgs.)

ALVES, PC., and MINAYO, MCS., orgs. Saúde e doença: um olhar antropológico [online]. Rio de Janeiro: Editora FIOCRUZ, 1994. 174 p. ISBN 85-85676-07-8. Available from SciELO Books $\langle$ http://books.scielo.org $>$.

\section{(1)(9)(2)}

All the contents of this work, except where otherwise noted, is licensed under a Creative Commons Attribution-Non Commercial-ShareAlike 3.0 Unported.

Todo o conteúdo deste trabalho, exceto quando houver ressalva, é publicado sob a licença Creative Commons Atribuição Uso Não Comercial - Partilha nos Mesmos Termos 3.0 Não adaptada.

Todo el contenido de esta obra, excepto donde se indique lo contrario, está bajo licencia de la licencia Creative Commons Reconocimento-NoComercial-CompartirIgual 3.0 Unported. 


\section{SAÚDEe DOENÇA \\ UM OLHAR ANTROPOLÓGICO}

Organizadores

Paulo César Alves Maria Cecília de Souza Minayo

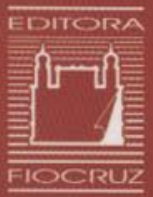




\title{
SAÚDE : DOENÇA
}

\author{
UM OLHAR \\ ANTROPOLÓGICO
}




\section{FUNDAÇÃO OSWALDO CRUZ}

Presidente

Paulo Marchiori Buss

Vice-Presidente de Ensino, Informação e Comunicação Maria do Carmo Leal

\section{EDITORA FIOCRUZ}

Diretora

Maria do Carmo Leal

Editor Executivo

João Carlos Canossa Pereira Mendes

Editores Científicos

Nisia Trindade Lima e Ricardo Ventura Santos

Conselho Editorial

Carlos E. A. Coimbra Jr.

Gerson Oliveira Penna

Gilberto Hochman

Ligia Vieira da Silva

Maria Cecillia de Souza Minayo

Maria Elizabeth Lopes Moreira

Pedro Lagerblad de Oliveira

Ricardo Lourenço de Oliveira 


\title{
SAÚDE : DOENÇA
}

\author{
UM OLHAR \\ ANTROPOLÓGICO
}

Quarta reimpressão

Organizadores

Paulo César Alves

Maria Cecília de Souza Minayo

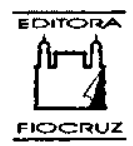


Copyright $^{\circ} 1994$ dos autores

Todos os direitos desta edição reservados à

Fundação OsWALdo CRUZ/ EDITORA

ISBN: 85-85676-07-8

$1^{2}$ edição: 1994

1ª reimpressão: 1998

$2^{\mathrm{a}}$ reimpressão: 2000

$3^{\text {a }}$ reimpressão: 2004

$4^{2}$ reimpressão: 2008

Projeto gráfico e ilustração da capa: Paulo Márcio Moreira

Editoração eletrônica: Heloisa Diniz

Revisão: Marcionilio Cavalcanti de Paiva

Supervisão: Walter Duarte

Revisão (1 $1^{\mathrm{a}}$ reimpressão): Mauro José Rocha do Nascimento

Catalogação na fonte

Centro de Informação Científica e Tecnológica

Biblioteca Lincoln de Freitas Filho

A474s Alves, Paulo Cesar (org.)

Saúde e doença: um olçhar antroplógico/organizadores Paulo Cesar Alves; Maria Cecília de Souza Minayo. - Rio de Janeiro : Editora FIOCRUZ, 1994. $174 \mathrm{p}$.

1.Antropologia. 2.Medicina alternativa. 3.Condutas terapêuticas. I.Minayo, Maria Cecília de Souza, org. II. Título.

CDD - 20.ed. -301

2008

EDITORA FIOCRUZ

Av. Brasil, 4036 - 1 andar - sala 112 - Manguinhos

21040-361 - Rio de Janeiro - RJ

Tels: (21) 3882-9039 e 3882-9041

Telefax: (21) 3882-9006

e-mail: editora@fiocruz.br

http://www.fiocruz.br

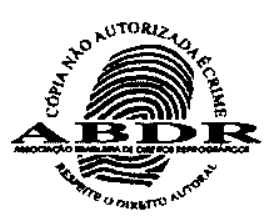




\section{Colaboradores}

\section{Cap. 1}

\section{Ana Maria Canesqui}

Professora da disciplina de Ciências Sociais aplicada à Medicina, Departamento de Medicina Preventiva e Social da Faculdade de Ciências Médicas, UNICAMP

\section{Cap.2}

Sérgio Carrara

Professor Assistente do Instituto de Medicina Social da UERJ; Graduado em Ciências Sociais pela UNICAMP; Mestre em Antropologia Social pelo Museu Nacional

\section{Cap. 3}

Miriam Cristina M. Rabelo

Professora (Ph.D) do Departamento de Sociologia e Mestrado em Sociologia e Antropologia da Universidade Federal da Bahia

Cap. 4

Maria Cecília de Souza Minayo

Antropóloga sanitarista, professora adjunta do Departamento de Ciências Sociais da ENSP/FIOCRUZ

\section{Cap. 5}

Raymundo Heraldo Maués

Departamento de Antropologia da Universidade Federal do Pará, Professor Adjunto IV; Doutor em Ciências (Antropologia Social) pelo Programa de Pós-Graduação em Antropologia Social do Museu Nacional/Universidade Federal do Rio de Janeiro

Cap. 6

Luiz Fernando Dias Duarte

Professor Adjunto (e atual Coordenador) - Programa de Pós-Graduação em Antropologia Social (PPGAS), Museu Nacional, Universidade Federal do Rio de Janeiro; Doutor em Ciências Humanas, UFRJ, 1985; Pesquisador do CNPq 


\section{Cap. 7}

\section{Paulo César Alves}

Professor (Ph.D) dos Programas de Pós-Graduação em Saúde Coletiva e Sociologia da Universidade Federal da Bahia

\section{Cap.8}

\section{Jaqueline Ferreira}

Médica com Especialização em Medicina Geral e Comunitária; Mestranda em

Antropologia Social-UFRGS; Doutoranda em Antropologia Social-UFRGS

\section{Cap. 9}

\section{Maria Angelica Motta-Maués}

Departamento de Antropologia da Universidade Federal do Pará, Professora Adjunta IV; Mestranda em Antropologia Social pelo Programa de Pós-Graduação em Antropologia Social da Universidade de Brasília

\section{Cap. 10}

Ondina Fachel Leal

Antropóloga; Professora Titular junto ao Programa de Pós-Graduação em Antropologia Social, Universidade Federal do Rio Grande do Sul

Cap. 11

Rubem C. F. Adorno

Professor Doutor do Departamento de Prática de Saúde Pública, FSP/USP

Ana Lúcia de Castro

Mestranda em Antropologia pela Pontifícia Universidade Católica, PUC/SP

Mara Melo Faria

Mestranda em Saúde Pública pela Faculdade de Saúde Pública, USP

Fabiola Zioni

Professora do Departamento de Prática de Saúde Pública, FSP/USP

Cap. 12

Marcos S. Queiroz

Ph.D. pela Universidade de Manchester; Pesquisador do NEPP-UNICAMP

\section{Cap. 13}

Jane A. Russo

Professora Adjunta do Instituto de Psiquiatria da Universidade Federal do Rio de Janeiro; Doutora em Antropologia Social pelo Programa de Pos-Graduação em Antropologia Social do Museu Nacional - UFRJ 


\section{Sumário}

$\begin{array}{ll}\text { Introdução } & 9\end{array}$

Capítulo 1

Notas sobre a produção acadêmica de antropologia e saúde na década de 80 Ana Maria Canesqui

Capítulo 2

Entre cientistas e bruxos - ensaios sobre dilemas e perspectivas da análise antropológica da doença

Sérgio Carrara

Capítulo 3

Religião, ritual e cura

Miriam Cristina M. Rabello

Capítulo 4

Representações da cura no catolicismo popular

Maria Cecília de Souza Minayo

Capítulo 5

Medicinas populares e "pajelança cabocla" na Amazônia

Raymundo Heraldo Maués

Capítulo 6

A outra saúde: mental, psicossocial, físico-moral?

Luiz Fernando Dias Duarte

Capítulo 7

O discurso sobre a enfermidade mental

Paulo César Alves

Capítulo 8

O corpo sígnico

Jaqueline Ferreira 
Capítulo 9

"Lugar de mulher": representações sobre os sexos e práticas médicas na Amazônia (Itapuá/Pará)

Maria Angelica Motta-Maués

Capítulo 10

Sangue, fertilidade e práticas contraceptivas

Ondina Fachel Leal

Capítulo 11

"Mulher, muler: saúde, trabalho, cotidiano"

Rubem C. F. Adorno; Ana Lúcia de Castro; Mara Melo Faria; Fabiola Zioni

Capítulo 12

Farmacêuticos e médicos: um enfoque antropológico sobre o campo de prestação de serviços de saúde em Paulínea

Marcos S. Queiroz

Capítulo 13

Terapeutas corporais no Rio de Janeiro: relaçōes entre trajetória social e ideário terapêutico

Jane A. Russo 


\section{INTRODUÇÃo}

O desenvolvimento da Antropologia da Saúde ou Médica é relativamente recente no mundo acadêmico. No entanto, essa disciplina tem apresentado nas últimas décadas um alto índice de crescimento. Tem não apenas despertado interesse por parte dos diversos tipos de profissionais da saúde como também sido reconhecida em diferentes instituições de ensino e pesquisa. Esse fato pode ser evidenciado pela vasta produção de livros e revistas publicados principalmente nos Estados Unidos, Inglaterra, Canadá e França.

No Brasil, os estudos direcionados para as crenças, valores e práticas terapêuticas, embora escassos, já indicam a existência de pesquisadores e núcleos emergentes de investigação que procuram, ainda que isoladamente, contribuir para o desenvolvimento de importantes aspectos teóricos e metodológicos dentro dessa área especificada da Antropologia. Tais estudos sāo resultantes de trabalhos elaborados por profissionais que, com raras exceções, obtiveram nesses últimos dez anos doutoramento ou especializações em instituições estrangeiras. Recentemente, alguns centros de ensino e pesquisas começaram a desenvolver programas de pós-graduação que procuram atender a um crescente número de alunos interessados pela Antropologia da Saúde. Como é de se esperar, o estudante dessa disciplina enfrenta algumas dificuldades, entre elas a disponibilidade de uma literatura especializada que, sendo basicamente circunscrita à língua inglesa ou francesa, pouco revela sobre a realidade brasileira.

Assim, tendo em vista essa situação e acreditando na contribuição que os estudos antropológicos têm a oferecer à Saúde Pública e à Medicina, é que apresentamos essa coletânea de textos. Em nível nacional, é a primeira tentativa, depois do número especial dedicado a essa temática pelos Cadernos de Saúde Pública, Vol. 9(3), 1993, de se colocar sob forma de livro um conjunto de observações elaboradas por pesquisadores diretamente interessados pela questão socioantropológica da saúde e da doença.

Os textos aqui reunidos representam uma pequena parcela, embora bastante significativa, dos estudos atuais desenvolvidos por profissionais dessa área. Cada artigo trata, de alguma forma, de problemas específicos da Antropologia da Saúde e nāo guardam necessariamente entre si identidades teórico-metodológicas ou doutrinárias estritas. Podese observar que, mais que um conjunto acabado sobre um saber determinado, a presente coletânea cumpre apenas o papel de apresentar um momento da discussão atual sobre 
questões socioantropológicas da saúde e medicina no Brasil. Assim, ao organizar esse livro não tivemos por objetivo resumir as diversas tendências téricas e metodológicas contemporâneas existentes no quadro atual da Antropologia da Saúde no Brasil. O leitor, portanto, não deixará de notar lacunas temáticas.

O conjunto de textos poderia, numa primeira leitura, ser classificado em quatro categorias. Uma primeira seria de abordagens que articulam o tema da saúde, doença e cura com a religiosidade popular. Há três estudos que abrangem essas dimensões e apontam para o caráter holístico da compreensão da vida e da morte; para o papel organizador da religião em relação aos estados confusos e desordenados dos processos de enfermidade; e ao contexto social amplo e totalizante a que se referem tanto a saúde, a doença, como a religião. Nesses trabalhos, o papel dos agentes de cura e dos rituais são ressaltados, trazendo contribuições e possibilidades de diálogo promissores para a prática médica oficial.

O segundo grupo de temas que compõe esta coletânea são as análises sobre o universo da "saúde mental", "nervoso", e problemas psicossociais. Trata-se de um recorte privilegiado para se compreender a cosmologia na qual se situam tanto "pacientes", "médicos", como a própria linguagem que faz a mediação desses sintomas de sofrimento trazidos por sujeitos que se movem dos serviços públicos de saúde às tendas espíritas, aos terreiros de macumba, aos chás dos curandeiros, numa combinação particular de suas expectativas com os serviços ofertados. Esses textos reafirmam premissas antropológicas de que os processos de saúde-doença tais como narrados pelos sujeitos são reais porque vivenciados por eles como frutos de interações e comunicações a partir das condições sociais de produção da vida e do conhecimento.

Um terceiro grupo de textos se refere às relaçōes dialéticas entre sujeito-objeto (que é sujeito) na configuração do campo das terapêuticas e da própria produçāo da enfermidade. Três desses estudos trabalham com recorte de gêneros e sua especificidade nas mudanças operadas no campo da subjetividade $e$ das intervenções médicas a partir da hegemonização das tecnologias modernas no terreno dos diagnósticos e dos tratamentos das doenças. Estes estudos apontam para problemas de gênero, de transformação do processo produtivo e da atenção à saúde. A categoria trabalho, nos três textos, se apresenta ora como produtora de cura, ora como construtora de subjetividade, ora como produtora de enfermidade.

Um quarto grupo coloca uma amostra das questōes hoje presentes no campo profissional de produção de agentes e de práticas terapêtuticas. Sobretudo o artigo "Médicos e Farmacêuticos" é um início de reflexão muito séria sobre os dilemas das mudanças propostas pela "reforma sanitária" e a distância estrutural entre a ideologia médica a a visão de necessidades da população.

O conjunto de trabalhos $e$ precedido por uma revisão da literatura que aproxima a antropologia do campo da saúde. Nesse texto a autora, Ana Maria Canesqui, retorna à trajetória da antropologia no Brasil e seu significado no campo intelectual, percorre os esforços internacionais e nacionais de aproximação com a área saúde e analisa a contribuição metodológica para os estudos interdisciplinares biomédicos e etnomédicos. Termina saudando a promissora aproximação dos dois campos, que floresceu sobretudo na última década. O texto de Sérgio Carrara executa uma leitura crítica do estado da arte enquanto acontecimento no interior do próprio I Encontro de Antropologia Médica. 
Todos os textos convergem para questionar o modelo que se fundamenta apenas na técnica, desconhecendo ou menosprezando o conteúdo de totalidade e abrangência que contorna os problemas de saúde.

Os artigos foram elaborados por pesquisadores que participaram do I Encontro Nacional de Antropologia Médica, realizado em Salvador entre os dias três e seis de novembro de 1993. A proposta desse evento partiu justamente da premissa de que já era tempo de reunir pesquisadores, professores e alunos que pudessem discutir as diversas tendências da Antropologia da Saúde no Brasil, maximizando o intercâmbio entre múltiplas perspectivas e tradições intelectuais dentro desse campo do saber.

O I Encontro Nacional em Antropologia Médica foi inicialmente idealizado durante a realização da II Conferência Brasileira de Epidemiologia, em Belo Horizonte (1992), promovida pela Abrasco. O número de pessoas atraídas pelo curso "Métodos Qualitativos em Pesquisas Epidemiológicas", ministrado pelos Professores Carlos Coimbra Jr. (EnspFiocruz) e Paulo César Alves (UFBA), evidenciou a necessidade da criação de um espaço que viabilizasse a comunicação e troca de idéias entre os interessados pela Antropologia da Saúde. A proposta se concretizou em reuniāo realizada na Escola Nacional de Saúde Pública no segundo semestre de 1992, com a participaçāo de Maria Cecília de Souza Minayo, Carlos Coimbra Jr., Marcos de Souza Queiroz e Paulo César Alves. Na época, pensávamos em um evento, nos moldes de um workshop, com o objetivo de debater apenas um pequeno conjunto de problemas. Foi criada uma comissão que seria responsável pela escolha de oito tópicos para discussão. Sob a coordenação do Prof. Paulo César Alves, a comissão reunia os Professores Maria Cecília de Souza Minayo, Carlos Coimbra Jr., Marcos de Souza Queiroz, Ana Maria Canesqui, Madel Luz, Miriam Cristina Rabelo e Naomar Almeida Filho. Tendo em vista o caráter do encontro, praticamente não houve grande divulgação. Em fins de junho de 1993, contudo, aproximadamente cinquienta propostas de comunicações já tinham sido enviadas. Em setembro, esse número chegou a cerca de noventa. Tal fato fez com que às vésperas do evento tivéssemos que ampliar os nossos objetivos iniciais e, apesar dos escassos recursos financeiros de que dispúnhamos, procuramos atender a uma grande parte das solicitações remetidas ao Programa de PósGraduação em Saúde Coletiva da UFBA, principal instituição responsável pelo encontro. Dessa forma poderíamos ter a oportunidade de conhecer o panorama geral do que estava sendo feito na área da Antropologia Médica brasileira. O evento se constituiria em um fórum de discussão no qual os participantes que apresentassem trabalhos, reclusos em local bastante informal, poderiam obter maior interação social entre si. Durante o encontro, foram apresentadas 82 comunicaçōes e proferidas cinco palestras, estas por convidados de instituições estrangeiras.

A comissão científica do encontro não estabeleceu a priori um critério rígido para definir o que seria o campo epistemológico da Antropologia da Saúde. Para um primeiro encontro seria um tanto problemático esse procedimento. Levou-se fundamentalmente em consideração o caráter processual da Antropologia da Saúde na construção do seu objeto de investigação. Cabe observar que essa disciplina, mesmo guardando especificidades enquanto estudo eminentemente disciplinar, situa-se na interface entre múltiplos saberes como a psicologia, a psicanálise, a filosofia, a história e a sociologia e intermedia a compreensão e o significado de outros como a educaçăo, a medicina, o direito e a 
administração. Além do mais, apesar de desconhecermos no Brasil dados concretos sobre o conjunto de pesquisadores atuantes nessa área, sabemos que grande parte deles estão alocados em hospitais, institutos de medicina social, escolas de saúde pública e departamentos de medicina preventiva. Esses fatores, dentre outros, podem ser responsáveis por levar a Antropologia da Saúde a horizontes ampliados, suscitando novas problemáticas e orientações metodológicas que ultrapassam os limites epistemológicos tradicionais. Assim, durante o I Encontro Nacional em Antropologia Médica, algumas das comunicações apresentadas não poderiam ser classificadas como pertencentes a um campo estrito da Antropologia. Nesse caso, eram trabalhos que tratavam de assuntos um tanto alheios aos cstudos antropológicos tradicionais mas que se utilizavam em grande medida de alguns recursos metodológicos dessa disciplina.

A idéia de publicar os resumos das comunicações foi a primeira que nos ocorreu. A concepção dos anais foi logo em seguida abandonada, tendo em vista que essa forma de publicação atende muito pouco aos interesses editoriais e dos leitores. Optou-se, portanto, pela escolha de alguns textos de caráter mais estritamente antropológico que scriam reproduzidos integralmente tal como foram apresentados durante o encontro.

Esperamos que este livro possa contribuir não apenas como material para as atividades de investigação e docência nas instituições de ensino e pesquisa como também para abrir caminho a um efetivo fortalecimento do debate entre todos aqueles interessados na melhoria do quadro de saúde da população brasileira.

Registramos o nosso agradecimento ao apoio financeiro prestado pelo CNPq, Capes, Cenepi, Secretaria Municipal de Saúde de Salvador, Universidade Federal da Bahia, Secretaria de Desenvolvimento Educacional da Escola Nacional de Saúde Pública e do Sindicato dos Médicos (seção Bahia) na realização do I Encontro Nacional em Antropologia Médica. Nosso especial agradecimento é também dirigido aos membros da comissão organizadora - Dra. Miriam Cristina Rabelo, Prof . Maria Gabriela Hita, Ana Beatriz D’Anna, Dr. Carlos Alberto Soares e os estudantes Lívia Alessandra, Antônio Marcos, Stella e Eduarda. 


\title{
NOTAS SOBRE A PRODUÇÃO ACADÊMICA DE ANTROPOLOGIA E SAÚDE NA DÉCADA DE 80*
}

\author{
ANA MARIA GANESQUI
}

Há um certo consenso quanto ao maior prestígio alcançado pela Antropologia, dentre as ciências sociais, nas últimas duas décadas. Mas os antropólogos, apesar de lisonjeados, estão sendo cuidadosos na assimilação desse prestígio, motivando-se a mergulhar e refletir mais cuidadosamente sobre a produção científica de sua disciplina. Esta reflexão assume várias direções e abordagens que se mostram de enorme valia à análise do desenvolvimento da antropologia em nosso país, ou da história do pensamento antropológico, sobre os quais alguns pesquisadores estāo debruçados, sem que ainda se disponha de uma verdadeira história das idéias desta área de conhecimento.

As várias revisões bibliográficas, contemplando a produção antropológica recente, em temas específicos (Durham, 1986; Magnani, 1981; Melatti, 1984; Oliven, 1989; Fernandes, 1990), apontam a sua expressiva quantidade, qualidade e diversidade, atestando o próprio sucesso da Antropologia, dentre as ciências sociais, como também alguns autores assinalaram os problemas mais preocupantes, os referidos à heterogeneidade das orientações teórico-metodológicas dos estudos, especialmente a ausência da integração das abordagens e o manejo descompromissado de vários conceitos de suas fontes téricas fundamentais, comprometedor da qualidade dos resultados (Durham, 1986).

A reação a este desconforto térico nāo é o abandono do que a antropologia sempre prezou na formação e no ofício antropológico - o trabalho de campo -, cercado, evidentemente, dos recursos metodologicos a ele inerentes e de todas as questões que o desvendamento e o encontro com o "outro" implicam. Mais do que isto, a reação também foi aprofundar os problemas de ordem conceitual e repensar o trabalho antropologico. Enfim, através de diferentes caminhos os antropblogos se perguntam - o que é a antropologia brasileira ou o que fazem ou fizeram os antropólogos?

Texto apresentado na mesa-redonda "Questões Metodologicas da Antropologia Médica". I Encontro Nacional de Antropologia Médica, Salvador, Bahia, novembro, 1993. Revisto para apresentação na mesa-redonda Antropologia e Saúde: corpo, pessoa e campo teórico. XIX Reunião da ABA. Niterói, 27 a 30 de março, 1994. 
No bojo destas preocupações e com uma perspectiva bem mais restrita e circunscrita, revisito nestas notas a produção acadêmica produzida no tema antropologia e saúde na década de 80, procurando contextualizar algumas condições de produção de pesquisa e os temas investigados, bem como sinalizar sua permanência, continuidades ou rupturas em relação a outros, abordados no passado. Trata-se de uma pesquisa bibliográfica, em andamento, que reuniu uma quantidade razoável de teses, artigos publicados em revistas, comunicações em eventos científicos, sob a forma de resumos ou de papers, livros e capítulos de livros, resultando num conjunto de cerca de 120 títulos, dos quais para estas notas fiz uma leitura selecionada.

Ressalte-se que esta produção acadêmica, que excluiu a bibliografia produzida na área indígena, revela o crescente interesse antropológico na análise do fenômeno saúdedoença, fugindo evidentemente à visão naturalizada, dominante no modelo médico biologicista e mecanicista. Configura-se, ainda, a presença antropológica na análise das distintas práticas de cura, seus aparatos institucionais e especialistas diversos, compondo um mosaico de pensamentos e práticas de cura (oficializados ou não), sempre crescentes em nossa sociedade urbano-industrial, repleta de contradições inerentes à realização desigual e combinada do capitalismo brasileiro. Não abordarei também os estudos nos seus marcos teórico-metodológicos.

Evidentemente, a década de 80 representa apenas um lapso de tempo recortado arbitrariamente para o estudo, inscrevendo-se no período "burocrático" (Oliveira, 1987), iniciado na metade dos anos 60 aos dias atuais, caracterizado pela maior consolidaçāo do campo antropológico. Nesse período inicia-se a reformulação, em novos moldes, dos cursos de pós-graduação, emergindo novas divisões do trabalho disciplinar pela substituição das lideranças carismáticas anteriores, com a racionalização na formação avançada em antropologia, assumindo a pesquisa condiçāo fundamental na capacitação dos antropólogos.

Foi também em função da Reforma Universitária de 1968 que se impuseram novas estruturas departamentais, diluidoras das antigas cátedras, com impactos nas estruturas institucionais concentradoras do poder, refletidas dentre as condições favoráveis à expansão da pesquisa. Do mesmo modo, aquela reforma também propiciou a expansão do ensino superior no país com suas conhecidas distorções, criando um novo mercado de trabalho universitário a ser formado nas diferentes áreas do conhecimento, dentre elas a antropologia, incorporando ainda o ensino superior em expansão, as demandas reprimidas dos estratos médios de nossa população, sedentas por um maior número de vagas e por ascensão social, através da formação universitária. Contudo, não se deve esquecer do desmantelamento de alguns centros formadores de cientistas sociais, provocado por perseguiçồes político-ideológicas do regime militar, às quais a Antropologia permaneceu mais imune, por seu caráter mais conservador em relação às demais ciências sociais (Durham, 1980). Com 0 advento da distensão do regime militar e da própria democracia, questōes daquela natureza deixaram de afetar as instituições acadêmicas.

No decorrer do período também oscilaram as condições de financiamento à pesquisa, conforme as flutuações do ciclo econômico e o direcionamento da política científica e tecnológica em relação às ciências sociais e especificamente à Antropologia e a outras áreas afins que incorporaram o conhecimento antropológico. Se o financiamento, oriundo 
das fontes governamentais nacionais, foi mais generoso a partir da metade da década de 70 , possibilitando a execução em equipe de projetos mais ambiciosos, na década de 80 os fluxos daqueles recursos oscilaram bastante, tendendo à escassez e dificultando o desenvolvimento da pesquisa, a não ser em projetos menos custosos, geralmente realizados individualmente. Selecionando determinados temas, um conjunto de organizações internacionais também mostrou-se interessado em financiar pesquisas multidisciplinares em temas envolvendo abordagens das ciências sociais como a saúde reprodutiva, ambiental e mental, a avaliação de serviços de saúde, dentre outros.

Inexiste ainda institucionalizada no Brasil uma subárea especializada do conhecimento antropológico dedicada ao tema, nos moldes existentes nos Estados Unidos, Inglaterra e de certa forma na França. Nos Estados Unidos, nas décadas de 40 e 50, a Antropologia penetrou os programas internacionais de saúde pública, dentre eles os dirigidos à América Latina e Brasil, sob forte influência da abordagem do funcionalismo-culturalista e dos estudos de George Forster e Redfield.

Estudos de comunidade foram realizados por antropólogos norte-americanos ligados ao setor de Antropologia Social do Instituto Smithsoniano, a partir das influências de Forster e Redfield. Embora esses autores tenham abordado, numa perspectiva integrativa, todos os aspectos da vida social de pequenos centros urbanos, também descreveram as doenças tradicionais, as terapias nativas, os tabus e crenças relacionadas à alimentação, gravidez, parto e puerpério. Apenas nos anos 60 apareceu a Antropologia Médica, assim designada como ramo aplicado da Antropologia Geral, fortemente associada à Epidemiologia e à Clínica, dedicando-se em linhas gerais ao estudo da incidência e distribuição das doenças, aos cuidados em instituiçōes médicas, aos estudos dos problemas de saúde em geral e à etnomedicina (Buchillet, 1991).

Entre as contribuições mais recentes de autores americanos está a discussão teórico -metodológica de disease, illness e sickness, com distinções entre a manifestação patológica ou biológica da doença, a percepção individual ou subjetiva da doença e a ordem cultural (Eisemberg, 1977; Kleinmam, 1978; Frankenberg, 1980; Young, 1982), tendo inspirado inúmeros estudos.

A Antropologia Médica americana conta com densa rede de especialistas, com volume significativo de publicações e de instituições acadêmicas dedicadas àquela formaçāo especializada, envolvendo a colaboraçāo dos departamentos de antropologia e as escolas médicas. Além disto, desde 1975 os especialistas estão organizados em torno da Society for Medical Anthropology.

Três razōes foram apontadas por Young (1982) sobre o desenvolvimento da Antropologia Médica nos Estados Unidos: uma delas está relacionada à emergência de um discurso antropológico sobre a enfermidade; a outra, ligada às novas oportunidades de trabalho, proporcionadas pelos esforços dos clínicos, insatisfeitos com o reducionismo biológico, tendo propiciado a inclusão de antropólogos junto à clínica e nos programas de atenção primária e familiar; e por último o alto estímulo financeiro proporcionado aos cientistas sociais interessados nos temas médicos. Contudo há correntes críticas da associação da antropologia à clínica, por sua subordinação ao modelo médico, propiciando inclusive a sua expansão. 
Na Inglaterra, clássicas etnografias enfocaram as práticas de cura, teorias da doença, especialmente os conceitos de mente e corpo; as acusações de feitiçaria, os cultos de possessão, os rituais de cura, notadamente os estudos de Evans-Pritchard (1937) e Turner (1968) por referência às sociedades africanas. Além disso, foram também considerados os problemas relacionados à saúde mental, aos hábitos dietéticos, especialmente nas sociedades orientais e africanas, nos primórdios da Antropologia Social inglesa. Importantes foram as contribuições dos médicos-antropólogos, dentre eles Rivers e Seligman, na década de 20, enfocando as teorias nativas sobre a causalidade mágica das doenças (Fortes, 1976).

Em 1968, uma avaliação da Antropologia Social inglesa, efetuada pelo Social Anthropology Committee, pertencente ao Social Science Research Council, presidido na ocasião por Raymond Firth, deixava nítida a incipiência daquele campo, ainda aberto à investigação dos problemas de saúde e dietéticos de alguns países africanos e orientais em processo de mudança e urbanização; das relações sexuais; do planejamento familiar e dos fatores afetando a fecundidade feminina, além das práticas médicas tradicionais, seus especialistas e suas relações com a clientela e a comunidade.

Desde o início da década de 70, o tema Antropologia Social e Medicina obteve maior impulso na Inglaterra, especialmente na pesquisa, diante do desenvolvimento do funcionalismo estrutural. Meyer Fortes via na maior popularidade da investigação em etnomedicina um importante campo para a atividade antropológica, por abrir o leque tanto do estruturalismo, pela ênfase na análise das idéias, como do funcionalismo, concernente aos fatos etnográficos do comportamento social. A pessoa total, como unidade de referência, e a saúde e doença, não como entidades clínicas abstratas, mas como experiências vividas pelos indivíduos, famílias e comunidades, eram princípios básicos a serem observados pelos antropólogos sociais (Fortes, 1976).

Esta é apenas uma das abordagens da Antropologia Social inglesa, e muitos estudos, na década de 70, centraram-se na análise dos sistemas médicos não-ocidentais, enfocando cosmologias, teorias das doenças, processos de cura, seus especialistas, e sendo fortemente influenciados pelos estudos de Evans-Pritchard e Victor Turner e pelas abordagens históricas sobre a formulação de teorias e pensamentos sobre as doenças. Estes autores não desenvolveram uma Antropologia Médica, mas a Antropologia da Religião e os modos de pensar a feitiçaria, os rituais, os símbolos e as estruturas. Alguns autores não falam de saúde e doença, mas dos infortúnios e suas prevenções, uma vez que saúde, doença, cura incluem tanto o corpo doente como a esfera mental, os problemas sociais, calamidades, conflitos e disputas pessoais e políticas (Evans-Pritchard, 1937; Wartovsky, 1976).

Mais do que uma estreita associação da antropologia com a clínica, a Antropologia inglesa aproximou-se da Medicina Social e Saúde Pública, com referência ao planejamento dos serviços de saúde. Entretanto, nos seus desdobramentos, como ramo da Antropologia Social, alguns centros formadores universitários capacitavam médicos e antropólogos em cursos de pós-graduação, incluindo disciplinas específicas de Antropologia Médica ou Antropologia Social e Medicina.

Na França, a Antropologia da Saúde ou da Doença, conforme distintos enfoques, é considerada uma disciplina bastante recente. Tanto uma como outra denominação privilegiam o significado ou as representações da doença, sua causalidade, as medicinas tradicionais e a medicina moderna. A escola francesa critica o pragmatismo americano da 
Antropologia Médica, propondo, em contrapartida, uma antropologia da doença afinada à teoria antropológica e capaz de renová-la (Augé, 1986). De toda forma, aquele campo de investigaçāo permanece dividido em diversas abordagens e interpretaçōes, que chegam até a ser competitivas entre si (Thomas, 1986). Diante do pluralismo etiológico e terapêutico, Laplatine propôs uma Antropologia da morbidez e da saúde, capaz de analisar as formas elementares da doença e da cura, numa perspectiva metacultural e comparativa. O esforço deste autor foi o de encontrar os modelos etiológico-terapêuticos na sociedade francesa contemporânea, sem excluir a comparação com outras sociedades (Laplatine, 1986).

A crescente bibliografia francesa envolvendo o tema Antropologia da Saúde ou da Doença, por referência àquela sociedade e outras "além mar", dentre elas o Brasil, evidencia a importância da pesquisa antropológica no tema nas últimas duas décadas, sem que disciplinas antropológicas específicas tenham penetrado o ensino das profissões de saúde.

Embora esteja em expansão no Brasil o interesse na pesquisa de temas relacionados a antropologia e saúde, inexiste ainda o consenso dos antropólogos de constituir esta subárea do conhecimento. Tanto é que nas últimas duas décadas a temática abordada pelos pesquisadores tem assumido diversas denominações: antropologia da saúde, antropologia nutricional, antropologia da ou $e$ saúde $e$ medicina, antropologia médica, o desvio, as aflições, perturbações físico-morais, pessoa, corpo, sob as quais configuram-se distintos enfoques das relações da antropologia com as ciências médicas ou interpretações sobre a doença, ou mesmo influências originárias dos centros formadores internacionais na área, onde alguns especialistas obtiveram capacitação pós-graduada ou com os quais pesquisadores estabelecem intercâmbio, apoiados pelo financiamento de agências governamentais nacionais (CAPES, CNPq). De toda forma, o esforço antropológico tem sido sempre assentado no trabalho de investigação, com avanços e vitalidade no campo de conhe-cimento.

Sob estas diferentes designações reúne-se uma rede ainda restrita de antropólogos ou de profissionais de saúde (esses últimos com formação pós-graduada em antropologia), dedicando-se à pesquisa e ao ensino junto às instituições acadêmicas, formadoras de cientistas sociais ou de profissionais de saúde (médicos, enfermeiras, sanitaristas, odontólogos e nutricionistas) ${ }^{*}$. Esta rede, ainda pouco orgânica do ponto de vista corporativo, à qual se associa um conjunto de alunos de pós-graduação em antropologia social, concentra-se em alguns centros formadores (UNB, UFRJ-Museu Nacional, UNICAMP, USP, UFRGS, UFSC, UFBa, UFPa, PUC-SP, UERJ, dentre outros), responsabilizando-se pela maior parte da produção antropológica no tema, juntamente com os especialistas situados em algumas instituições acadêmicas, pertencentes às áreas de Saúde Pública, Medicina Social e denominaçōes congêneres.

Além disso, essa produção acadêmica vem a público pelos tradicionais veículos de divulgação científica e nos eventos organizados pelas diferentes associaçōes, específicas ou não às áreas de ciências sociais (Associação Brasileira de Antropologia - ABA; Sociedade Brasileira para o Progresso da Ciência - SBPC; Associaçāo Nacional de

Um levantamento recente, ainda incompleto, dos cientistas sociais dedicados à área da saúde (Abrasco, 1993), identificou apenas seis profissionais, entre 110, mencionando a antropologia e saúde como seu campo de interesse. Do catálogo de antropólogos (ABA, 1988), 13 profissionais identificaram suas pesquisas no tema. 
Pós-Graduação em Ciências Sociais - ANPOCS; Associação Brasileira de Saúde Coletiva - Abrasco) e mais eventualmente nas pertencentes a algumas associaçōes do campo psiquiátrico.

Vale destacar a organização, na década de 80 , no Brasil, de vários grupos de trabalho e de mesas-redondas sobre o tema Antropologia e Saúde, por ocasião das reuniões bienais da $\mathrm{ABA}$, propiciando o intercâmbio e a discussão dos pesquisadores sobre os assuntos investigados. Além disto, ocorreu, no início da década, a criação do Centro de Estudos e Pesquisas em Antropologia Médica (1982), sob a iniciativa de antropólogos ligados à Universidade de Brasília e de médicos epidemiólogos interessados, na ocasião, em saúde mental, nutrição e saúde indígena. Apesar da efêmera existência, o Centro chegou a divulgar o Boletim Cepam, contendo informações bibliográficas, notícias sobre eventos e reuniōes científicas do novo campo que se queria estabelecer. Seria mesmo oportuno perguntar se esta idéia năo subjaz à tendência de se criar uma antropologia médica no Brasil.

A crescente produção acadêmica no tema, como de resto na antropologia em geral, revela o próprio amadurecimento e consolidação do campo antropológico no Brasil no plano do conhecimento, moldando-se por condições de natureza político-institucionais, afetando mais de perto o trabalho antropológico, suas distintas formas de organização, o conjunto de seus recursos - inserido esse conjunto de elementos na dinâmica política e econômica da sociedade num tempo histórico -, que não só coloca problemas à reflexão, como limita ou amplia as possibilidades de realização da pesquisa antropológica.

\section{ALGUNS TEMAS PESQUISADOS}

A Antropologia feita no Brasil nas últimas duas décadas, e particularmente na década de 80 , tem produzido conhecimentos sobre os temas alimentação, saúde, doença, que afligem principalmente as classes trabalhadoras ou alguns grupos minoritários. Tem também estudado os distintos saberes e práticas de cura, suas instituiçōes e especialistas em diferentes regiões do país, adentrando os saberes e práticas da medicina oficial e as tentativas de reformulação de modelos assistenciais tradicionais e asilares da loucura (a exemplo da reforma dos manicômios), ou as questôes afeitas à extensão dos cuidados médicos e seu confronto ou complementaridade com outras práticas de cura, especialmente aquelas inscritas no campo religioso (umbanda, pentecostalismo, espiritismo kardecista). Na literatura mais recente também estão presentes temas relacionados às práticas corporais, à emergência de novas e antigas epidemias (aids e esquistossomose), à sexualidade e reproduçāo.

Antes de adentrar os temas pesquisados na década de 80 é preciso mencionar que desde a metade da década de 70 revitalizou-se o interesse antropológico em questões relacionadas à saúde, destacando-se principalmente os estudos dos hábitos e ideologias alimentares e análises eventuais sobre as concepçōes do corpo e as curas religiosas. O tema hábitos $\mathrm{e}$ ideologias alimentares reuniu vários pesquisadores sob um projeto coordenado por Klass Woortmann, da Universidade de Brasília, e Otávio Guilherme Velho, do Museu Nacional (UFRJ-Rio de Janeiro), mediante o apoio da Financiadora de Estudos e Projetos 
(FINEP), além de outros pesquisadores isolados que se dedicaram ao tema (Peirano, 1975; Canesqui, 1976), bem como os estudos de caso valendo-se da análise antropológica realizada no âmbito do Estudo Nacional de Despesas Familiares (FIBGE, 1974/1975), também apoiado pela FINEP.

Além do suporte financeiro e do interesse das políticas governamentais no tema nutrição e saúde, no campo da antropologia, tanto crescia a sensibilidade pela dramaticidade social, como novas abordagens (dentre elas o estruturalismo francês e inglês) eram assimiladas pela academia, refletindo-se nos estudos realizados. Assim foram estudadas as taxonomias populares e dos profissionais de saúde a respeito do corpo humano, conluindo-se que o universo classificatório que informa as concep̧̧ões e os tratamentos relativos à saúde e doença encerram explicações sobre o universo cultural e o modo de inserção dos sujeitos na sociedade (Ibañez-Novión, 1978; Ibañez-Novión e Trindade Serra, 1978).

O projeto hábitos e ideologias alimentares comportou uma diversidade de enfoques e de situações investigadas. Entre as situações camponesas, os hábitos articularam-se aos domínios da produção e comercialização dos alimentos, desvendando-se o ethos e concepçōes de cada grupo (Velho, 1977; Lins e Silva, 1977; Pacheco, 1977; Marcier, 1977; Bastos, 1977), as novas situações de mercado, tanto quanto a prática, a experiência e o significado atribuídos pelos grupos sociais diante dos novos ou antigos hábitos, respondendo aquele conjunto de elementos por suas modificações ou permanências.

Outros estudos no tema enfocaram as classificações alimentares, por analogia ao totemismo de Lévi-Strauss (Peirano, 1976). Estudando a categoria "reima" presente no sistema classificatório dos alimentos, entre pescadores do Ceará, a autora atribuiu à proibição dos alimentos reimosos (certos peixes) a aproximação simbólica dos domínios da natureza e cultura: de um lado, as espécies de peixes, de outro, os seres humanos. Estas proibições também envolvem pessoas em determinadas situações e estados de saúde e doença. A lógica cognitiva e simbólica de categorias alimentares (quente/frio, forte/fraco, reimoso/descarregado), caracterizando um modelo etnocientífico tradicional, presidindo as prescrições, proibições e os hábitos foi também considerada (Woortmann, 1978).

Maués e Maués (1978; 1980) analisaram as proibições alimentares entre pescadores de Itapuá-Pará, não chegando a rejeitar as formulações de Lévi-Strauss, empregadas por Peirano, para entender o modelo classificatório da "reima", considerando-o um sistema paratotêmico, a despeito de se darem conta da insuficiência desta explicação. Agregaram a contribuição de Douglas (1976) sobre a oposição simbólica "puro e impuro". Desta forma, alimentos impuros (reimosos) devem ser afastados de pessoas impuras ou em situações liminares, sob pena de agravarem a sua contaminação social, com sérias conseqüências para a saúde.

Descartando o caráter de um sistema único classificatório presidindo os hábitos alimentares, Velho (1977) admite vários princípios a serem verificados caso a caso. São eles os relativos à relação dos alimentos e o binômio natureza/sociedade nas suas formas concretizadas, dos alimentos e do organismo humano, comportando concepções particulares de saúde e doença e os princípios ligados à prática social de cada grupo. A pesquisa de Brandão, realizada em 1976, entre lavradores de Mossâmedes, Goiás, enfocou as condições de produção dos alimentos e a prática de consumo alimentar. Esta prática obedece a padrões sociais, apresentada sob a forma de hábitos. A ideologia alimentar, por 
sua vez, foi entendida pelo autor como parte do conhecimento social da população, comportando representações das crenças e dos padrōes sociais de uso e das restrições alimentares (Brandão, 1981).

Levando-se em conta os segmentos das classes trabalhadoras urbanas, sejam as situadas nos contextos metropolitanos, como as de cidades interioranas, outros estudos (Canesqui, 1976, Marim, 1977; Souto de Oliveira, 1977; Guimarães, 1979) enfocaram a forma de manutenção cotidiana ou as estratégias de sobrevivência dessas camadas, suas representações e práticas relativas ao consumo alimentar, tendo em vista a organização do consumo familiar, os modos de pensá-lo, tanto quanto a análise de um conjunto de categorias alimentares e de regras de uso dos alimentos, envolvendo relações com o trabalho, organismo humano, estados fisiológicos, situações sociais e distribuição do tempo na sociedade urbano-industrial. Ao incorporarem as dimensões ideológica e cultural, articulando-as a outros domínios da estrutura social, em particular à condição de trabalhadores assalariados, os hábitos e ideologias alimentares daqueles grupos sociais não apareceram nestes estudos como crenças irracionais que podem gerar subnutrição e doença. Mas são como dimensōes mediadoras, presidindo as práticas e a organizaçāo do consumo doméstico, ou mesmo as estratégias de sobrevivência.

Na década de 80, o tema alimentaçāo mereceu menor atenção dos pesquisadores, a não ser através de reflexōes sobre o seu valor cultural, pela ênfase nos aspectos simbólicos envolvidos na "comida", nos modos de preparo, consumo e seleção dos alimentos (Cravo e Daniel, 1989).

Os elos estabelecidos entre o pensamento médico e o antropológico na constituição de práticas científicas e judiciais, cujas origens remontam ao fim do século XIX, adentrando o nosso século, foram temas de alguns estudos. Partindo da inquietação com as práticas que afetam o cotidiano do cidadão (por exemplo, o sistema de identificação, a reclusão e repressão de loucos e criminosos), os estudos associaram a história à antropologia, investigando os discursos e práticas, não só engendrados nas teorias, mas nas suas articulaçōes com determinadas práticas institucionais, jurídicas e com os processos sociais que lhes dão origem.

Alguns destes estudos remeteram à investigação das concepções antropológicas positivistas e biodeterministas, associadas ao pensamento médico na constituição da Medicina Legal, de práticas classificatórias das pessoas, pela hereditariedade e o caráter, formando outras práticas médico-legais e jurídicas (Correa, 1980; 1982). Desvendando as ambigüidades de instituições, onde coabitam prisão e asilo, penitenciária e hospício, Carrara (1987) valeu-se da abordagem histórica (a nova história de Paul Veine, Legof e Foucault) para compreender o significado do surgimento da instituição de tipo manicomial, criada no Rio de Janeiro na passagem do século. Analisa o significado das categorias criminalidade, loucura e degeneração, através das discussōes intelectuais (os discursos eruditos e científicos da psiquiatria e da antropologia criminal) e a prática judicial dos tribunais sobre a qual incidiam aquelas discussōes.

Desta feita, compreende a ambigüidade da estrutura institucional, refletindo tanto o significado controvertido da degeneração, como os embates entre positivistas e liberais em torno daquela estrutura manicomial, entendida como prisão por uns e como tratamento de regeneração por outros. $O$ autor dá mostras da intrincada relação das teorias e a 
constituição das práticas judiciais e de instituições de nossa sociedade que encerram e perseguem criminosos e loucos.

Dos vários estudos de Duarte, contemplados restritamente nestas anotações, podese também extrair contribuiçōes de natureza "histórica" (as aspas sāo do próprio autor), na genealogia das representações do "nervoso" nas classes trabalhadoras (Duarte, 1986). Filiado às preocupações de Dumont, o autor submete a análise das representações do "nervoso" a uma perspectiva mais global, para entender a construção do mundo e de pessoa na sociedade moderna. Assim, por referência à genealogia do campo de significações do "nervoso" e de sua constituição no sistema físico-moral, no Brasil, o autor, a partir dos vários princípios ordenadores da configuração daquela categoria nos diferentes discursos eruditos e letrados, demonstra a diversidade de modelos, tipologias, visões de mundo e estratégias neles contidos.

Atravessando tradições muito antigas, foi particularmente nos séculos XVII e XVIII que se constituiu o sistema letrado do nervoso, entre outros, que se prestam à representação moderna do homem. No século XIX é que o modelo dos saberes médico-psicológicos se comprometeram com o indivíduo, com a ideologia individualista e com a construção de pessoa na sociedade moderna.

Ao estudar a configuração do "nervoso" nas classes trabalhadoras urbanas, cuja cultura é hierárquica e holística, o autor, enfocando as múltiplas configurações do "nervoso", demonstra as especificidades de pensar o mundo e a pessoa, não coadunada com o modo individualista e substantivista da ideologia dominante em nossa sociedade.

Instigado com as características daquela cultura, tanto quanto com a análise antropológica, circunscrita às experiências etnográficas, o autor ofereceu uma análise original e densa, nos parâmetros estruturalistas, das categorias e modelos sobre as perturbações físico-morais. Para ele, as categorias e modelos sobre os mal-estares, as perturbações físico-morais ou as doenças são sempre uma via régia de acesso à representação de pessoa e de mundo vigentes em qualquer cultura (Duarte, 1986, 1988).

Abordando o tema instituiçōes e práticas psiquiátricas, outros estudos mais circunscritos e com distintos graus de refinamento teórico-metodológico se inscreveram nas etnografias que também aproximaram os antropólogos da arena médica, como objeto de pesquisa. Trata-se de estudos empreendidos nos hospitais psiquiátricos (Lougon, 1987), enfocando as relações burocráticas versus as informais, a implementação de novas modalidades psiquiátricas ou as relações sociais (Venâncio, 1990) e a comunicação das equipes terapêuticas com os familiares (Perelberg, 1980).

Sem adentrar o mérito deste estudos, vale observar as tensões e conflitos entre o ser técnico e o membro das equipes, e a opção de pesquisar a propria instituição ou, noutra situação, sendo antropólogo que privilegia o hospital psiquiátrico para efetuar o seu trabalho de campo. No primeiro caso, a confusão advém da permuta da observação participante pela participação observante, como nos lembra Durham (1986), ou na circunscrição do estudo, ao campo formal da instituição, por dificuldades do pesquisador de promover o descentramento das situações que lhe são familiares. No segundo caso, as dificuldades advêm do estranhamento do antropb́logo em relação aos diversos discursos sobre a loucura - que se entrecruzam no espaço institucional -, quando o pesquisador quer analisar os diálogos estabelecidos com o louco no nível das designações, estigma ou 
acusações que permeiam as relações sociais, descartando a produção e os significados sobre a loucura pelos distintos saberes médico-eruditos e não-eruditos. Portanto, em ambas as situações o estranhamento do pesquisador requer maiores cuidados para não comprometer os resultados da pesquisa.

Deve-se ressaltar que o crescente interesse dos antropólogos tanto quanto dos diferentes profissionais de saúde mental no estudo das instituições e práticas psiquiátricas na década de 80 esteve no bojo dos movimentos reformadores das várias instituições de reclusão da loucura (asilos, manicômios judiciários, hospitais psiquiátricos) animados pelo processo democrático e particularmente pela reforma das práticas tradicionais psiquiátricas questionadas pela antipsiquiatria e por outras correntes penetradas no Brasil desde o início da década de 70.

A antropologia não esteve alheia deste debate, não se limitando exclusivamente à análise daquelas reformas, pelo contrário, a indagação sobre a constituição dos distintos saberes e práticas no campo mental, como noutros, constituiu via de acesso importante ao entendimento da nossa cultura, como também não deixou de oferecer referenciais à constituição de novas práticas, mesmo que essas não configurassem no horizonte imediato das investigações.

$\mathrm{Na}$ década de 70 a teoria do comportamento desviante desindividualizou a doença mental para situá-la sob a marca do sociocultural (Velho, 1979), como também mostrou que a lógica da loucura ou perturbação é a da ordem do indivíduo (cultura individualizada) ou das relações entre os indivíduos (Guedes, 1979). Na década de 80, esta discussão minimizou o desvio, enfatizando sob novas abordagens a relação indivíduo e sociedade. Dentre essas destacam-se as contribuições de Duarte (1986), que tem discutido a relaçāo da cultura e a psicanálise, cuja literatura é abundante e não foi contemplada neste trabalho.

O campo psi passou a ser cada vez mais estudado, tanto por antropólogos quanto por psiquiatras, psicólogos e psicanalistas interessados e treinados nos métodos antropológicos. Sem esgotar esta literatura, mesmo por referência ao período investigado, outros autores procuraram as razōes culturais sobre a inoperância terapêutica da psicanálise no atendimento às camadas populares (D'Amorin, 1984), outros ainda investigaram a lógica que ordena as concepçōes e práticas terapêuticas populares sobre a loucura (Alves, 1982), bem como a integração do atendimento psiquiátrico à clínica, num modelo renovado assistencial a partir do encontro médico-paciente (Cardoso, 1986).

Além das representaçōes, dos saberes e práticas referidos à doença mental, várias pesquisas enfocaram as representações de saúde e doença, em geral ou específicas, especialistas e práticas de cura, mediante pesquisas empíricas realizadas entre as classes trabalhadoras urbanas, e mais raramente entre segmentos da classe média, engrossando as inúmeras etnografias que, desde a década de 70 , se preocuparam com as diferentes manifestaçōes culturais, com o modo de vida daqueles segmentos sociais urbanos, procurando ao mesmo tempo incorporar novas abordagens (o estruturalismo, o marxismo gramsciano) que pudessem animar a disciplina.

Se mesmo na década de $70 \mathrm{já}$ se reconheciam politicamente outros espaços que não os da fábrica ou do sindicato onde se faz a classe, na década de 80 , instituições, bairros e favelas tornaram-se também politicamente relevantes à militância, embora nem todos os estudos realizados tenham se restringido a estas intenções. $O$ fato é que a Antropologia 
voltava-se cada vez mais para a cidade, e as classes trabalhadoras urbanas, moradoras da periferia, passaram a ser mais intensamente procuradas pelos pesquisadores, sem que se constituísse uma Antropologia urbana (Durham, 1986). Neste contexto, várias investigações privilegiaram o estudo das distintas manifestações culturais das classes trabalhadoras, ganhando relevância os modos de vida e comportamentos a partir de distintos temas e enfoques sobre a cultura ou a ideologia. Por vezes, alguns estudos circunscreveram-se às falas dos entrevistados, das quais se extraíam as representações (certas imagens significativas) descartando-se qualquer processo analítico. Na pior hipótese o povo sabe e isto basta. E o pesquisador é mero tradutor ou porta-voz dos anseios populares, conclamando por participação.

Esta caricatura aplica-se mais aos desavisados da complexidade da pesquisa antropológica, que crêem na transparência dos discursos ou dos comportamentos, descartandose compromissos com a análise teórica. Isto também foi exceção nos estudos analisados. Mas a diversidade de enfoques teórico-metodológicos está presente nos estudos das representações de saúde e doença, não cabendo reconstruí-las, o que foi feito por Minayo (1992). Apenas aponto alguns conceitos empregados nos vários estudos: idéias, visāo do mundo, formas de pensamento, identidade, significado, crenças, valores, imaginário e percepção, sem que os autores, por vezes, permaneçam fiéis aos marcos teóricos que deram origem àqueles conceitos, dentre eles, a tradição durkheimiana, o marxismo, a psicologia social e a filosofia.

Alguns autores enfocaram as representações populares de saúde e doença como um corpo de idéias permanentemente criadas, recriadas e reelaboradas pelas classes trabalhadoras e nāo apenas legitimadas pelas classes dominantes (Costa, 1980). Neste sentido, as concepções dominantes do corpo, saúde e doença se constroem na prática médica oficial dominante, representando o pólo dominado pela cultura somática, que retraduz, reordena, na sua lógica, os efeitos da difusão da medicina científica. Outros autores, com maior radicalidade, estabeleceram o caráter de oposição das culturas eruditas e populares, identificando na medicina popular praticada por benzedeiras, na cidade de Campinas (Oliveira, 1983a, 1983b), uma alternativa eficaz para resistir aos domínios da medicina erudita, a partir dos pressupostos da criatividade e autonomia da cultura popular, ignorando a interpenetação de ambas.

Loyolla $(1984,1987)$ atenuou o mecanismo da dominação da medicina introduzindo as mediaçōes dos diferentes saberes hierarquizados no campo da oferta de serviços de cura que interferem nas concepçōes do corpo das doenças e da saúde das classes trabalhadoras, nāo descartando a importância da hierarquia social no quantum de capital cultural e econômico detido tanto pelos especialistas de cura como pela clientela por ela estudados em Nova Iguaçu, Rio de Janeiro.

Ao investigar as concepçōes do corpo, origem e classificação das doenças, tentando esboçar um modelo ou representação do funcionamento corporal, endossa a perspectiva de Boltanski (1979), assegurando não um princípio geral causal capaz de estabelecer as representaçōes, mas um raciocínio de tipo analógico, funcionando com pares de oposiçāo binárias simples, onde a realidade é recortada e reconstruída pela inclusão dos elementos em jogo (doença do corpo/doença do espírito; de Deus/dos homens) recobrindo outras categorias simples ou universais referidas ao espaço, tempo, ao atributo ou substancialidade 
das coisas. Essas categorias também se associam às categorias sociais; aplicam-se às doenças materiais, não esgotando, contudo, as concepções e a origem das doenças, desde que essas ainda se classificam de acordo com a intensidade e gravidade do mal, tanto quanto pela tradição e experiência do grupo social. Além disso, a percepção de saúde e doença tem a ver com a idéia de força e o uso social do corpo.

Estabelecendo a comparação da visão de saúde e doença das clientelas da homeopatia e da medicina popular, Loyolla (1987) associa-a, em parte, à posição de classe. Enquanto os primeiros, sujeitos ao intenso uso do corpo (profissional e utilitário) como elemento imprescindível à provisão de sua subsistência, definem saúde e doença a partir das categorias força/fraqueza, a clientela da homeopatia organiza suas representaçōes em torno das categorias equilíbrio/desequilíbrio, reproduzindo no plano simbólico a posição equilibrada e equilibrante entre as camadas privilegiadas e as expropriadas. Saúde, para essa clientela, é sinônimo de equilíbrio/desequilíbrio orgânico e emocional, tendo em comum com os clientes da medicina popular a negação do dualismo corpo/espírito, corpo/alma, objetivismo/subjetivismo e o próprio mecanicismo orgânico da medicina oficial, valorizando as categorias corpo/cabeça. Segundo a autora, a clientela da medicina popular, por sua vez, trabalha com as categorias espírito/matéria, negando a existência da doença mental.

Em outros estudos, as representações (idéias) se constroem no confronto, na luta com a classe dominante, mediada pelo Estado, seus aparatos -dentre eles a medicina e seus agentes -, embora nāo sejam uníssonas as concepçōes médicas sobre o corpo, saúde e doença. Mesmo admitindo que os trabalhadores participam das idéias dominantes, eles criam os seus próprios códigos de acordo com o lugar que ocupam na sociedade, traduzido no seu modo de vida. As representações também remetem às raízes tradicionais (crenças, valores) relativos à morte, vida, ao corpo e às experiências de vida. Esta linha de estudos resgata as representações na perspectiva das relações de poder e nos movimentos sociais e de participação, procurando identificar nas idéias e práticas as resistências à dominação (Minayo, 1988, 1989).

As representações sociais de saúde/doença, para Minayo, abarcam múltiplas dimensões, como expressões social e individual, envolvendo significaçōes culturais e relações sociais, e como manifestações das contradições sociais e da luta política. São, portanto, totalizantes as representaçōes de saúde e doença das classes trabalhadoras, por abranger concepção do homem como corpo, alma, matéria, espírito, e incluir as relações afetivas e as condiçōes de vida e trabalho. E mesmo que elas se subordinem conflitivamente ao processo de medicalização, como também ao capital enquanto força de trabalho, elas sāo contraditoriamente capazes de aceitar como de resistir ao sistema de dominação social.

A questão da resistência à dominaçāo médica também se faz presente nos estudos sobre as curas nos sistemas religiosos (Montero, 1985), a partir das fontes gramscianas. Para a autora, "o discurso da doença elaborado pelas religiões populares se constrói no interior e a partir dos balizamentos colocados pelo discurso oficial; ele exprime as contradições objetivas que encerram sua produção" (Montero, 1985:10). Conseqüentemente, a produçāo iđeológica dos grupos subalternos, na ausência de um jogo próprio, é capaz de minar, subverter e de improvisar no interior de um sistema de forças definidos de antemão. Na reconstrução histórica sobre a conquista da hegemonia da medicina sobre as 
demais formas, saberes e práticas de cura, a autora situa a umbanda, que representa uma resposta recriada, no domínio simbólico, tanto às restriçōes impostas pela medicina oficial às demais práticas de cura, como ao processo de urbanização. A doença como desordem, cujo significado é encontrado pela autora, no discurso religioso, como desorganização da pessoa, da ordem social e da ordem cósmica favorece, nas classes subalternas, a emergência da consciência tanto quanto a referência teórica para a organização do mundo, seus conflitos, e da posição do indivíduo.

A novidade na década de 80 , no que se refere aos estudos da medicina popular ou dos demais sistemas de cura, consolidados ou não nas diferentes religiōes, foi a superação das dicotomias (tradicional/modemo, sagrado/profano, lógico/ilógico) que estiveram presentes nas análises influenciadas pelo funcionalismo culturalista americano do passado, por referência à superioridade da medicina alopática. Tratava-se, agora, de colocá-las em relação de complementaridade e/ou subordinação num campo de relação de poder. Desde fins da década de 70 , em recusa aos pressupostos anteriores da alienação das classes trabalhadoras, como produto da interpretaçāo marxista mais ortodoxa ou dos pressupostos da exclusão ou da precária inserção daquelas classes no sistema produtivo, algumas leituras marxistas passaram a valorizar a questão da cultura e da ideologia.

Entretanto, essa foi apenas uma, entre outras vertentes incorporadas, tanto na análise das representaçōes de saúde e doença das classes trabalhadoras, como na análise das formas do pensamento religioso, cosmologias e de outros sistemas de cura que mereceram a maior atenção dos antropólogos na década de 80.

Uma destas abordagens, oriunda da Antropologia Social inglesa (Gluckman, 1966; Turner, 1974) - incluindo a situaçāo de transiçāo e os valores e a manipulação da realidade pelos atores, a resistência cultural e política -, está presente nos estudos de Queiroz sobre as concep̧̧ões e práticas de cura do caiçara de Iguape (SP), por referência à teoria etnológica da doença, calcada no quente/frio. Esta teoria envolve causas distintas: o desequilíbrio do corpo com o meio exterior ou o desequilíbrio moral em relação ao meio social, sendo compartilhada tanto pelo caiçara como por alguns especialistas de cura (espiritualistas $\mathrm{e}$ curandeiros do mato). Mas à medida que penetrava naquela sociedade, o modo de produçāo capitalista, nāo só a terra, como a cultura, gradualmente se apropriaram.

O autor estuda as tensas relações dos médicos com os demais agentes de cura e a posição intermediária do farmacêutico (curandeiro da cidade) entre o saber popular tradicional calcado na lógica quente/frio e o saber dos médicos, além do seu prestígio e do uso dos medicamentos modernos. Por tudo isso, o farmacêutico é o agente capaz de compartilhar, ainda que parcialmente, do sistema quente/frio, como também agrega novos conhecimentos à cultura tradicional do caiçara, ao contrário dos médicos (Queiroz, 1978, $1980 \mathrm{a} ; 1980 \mathrm{~b})$.

Noutros textos, o autor aprofunda a lógica do quente/frio como uma lógica que se aplica à classificação alimentos e ervas medicinais, conferindo desempenho terapêtico diferencial desses elementos no corpo humano, de forma que doenças quentes devem ser tratadas com ervas medicinais e alimentos frios, ao contrário das doenças frias (Queiroz, 1984). Ao dedicar-se ainda ao modo de percepção social da doença, o autor analisa as crenças de mau-olhado, quebranto, feitiço e susto que se encontram na origem de muitas doenças ou dos infortúnios. 
Seguindo Gluckman (1973), sugere Queiroz que as crenças e práticas são dotadas de sentido pela vida social e política, mesmo diante da implantacão de novo ethos capitalista. Ao contrário da lógica do quente/frio, aquelas crenças não se mostram enfraquecidas diante dos processos de mudança social. Além disso, esse conjunto de crenças não provoca doenças curáveis pela medicina, requerendo a intervençāo especializada de agentes de cura (curandeiros espiritualistas e benzedeiras), capazes de manipular códigos particularistas ou moral e político aplicáveis aos indivíduos e suas idiossincrasias, em oposição ao código universalista ou natural-biológico, que serve às doenças em geral e a todos os indivíduos (Queiroz, 1980c).

Outros autores que estudaram as religióes ou práticas simultaneamente religiosas e terapêuticas descartaram a sua comparação ou oposição em relação às práticas científicas, mesmo que, em termos de representação destas práticas, haja referência à medicina. $O$ enfoque passa a ser as instituições que realizam aquelas práticas num campo de relações sociais que estruturam e criam seus mecanismos de ação (Neves e Seiblitz, 1984), na tentativa de estabelecer uma análise mais totalizante e ao mesmo tempo particularizante em relação às instituições religiosas.

Assim compartilhando esse enfoque, as autoras estudaram a operação fluídica como prática terapêutica e religiosa, inscrevendo-a na concepção de mundo que orienta o kardecismo, onde os sofrimentos humanos são causados pelo grau de evolução dos espíritos reencarnados ou pelas agressões oriundas de espíritos desencarnados, que se expressam como mal-estar físico ou psicológico. A doutrina prevê um conjunto de serviços, o desenvolvimento mediúnico, a operação fluídica, visando a purificar o espírito e minimizar os sofrimentos. Ela opera não tanto com a doença, mas com a consolidação do sistema de crenças, diante do indivíduo que se sente inseguro, se inscrevendo também no campo de relaçöes de força das distintas instituições kardecistas.

Os rituais de cura na Assembléia de Deus, investigados em Nova Iguaçu (Pessanha, 1984) tematizaram a doença num sentido positivo, reafirmando a condição de eleito do cliente, tanto para os crentes como para os agentes eclesiásticos. Além disto, constroem simbolicamente a pessoa do crente, explicando ainda a etiologia da doença. Enfim, os rituais reordenam a ordem idealizada. Outros autores enfocam as relaçōes simbólicas e sociais implicadas na atividade religiosa, que incluem a prática de cura divina pelo exorcismo dos espíritos malignos. Na articulação da experiência social e religiosa estão presente os jogos de poder entre as várias instâncias e, em outro nível, esses elementos remetem à unidade e diversidade, centralização e multiplicidade presentes na sociedade (Rodrigues, 1984).

Da análise da cosmologia subjacente a outros sistemas de cura, como a homeopatia, (Musumeci, 1988) remete a um conjunto mais amplo das representações da doença, cura e saúde, por referência ao aspecto moral e ao paradoxo que inscreve a possiblidade de cura (saúde) no terreno da própria doença, no esforço de apreensāo da individualidade, situando-se a visão unicista da homeopatia nas tradiçōes religiosas e filosóficas modernas da existência humana.

Há ainda um volume significativo de estudos que deixei de considerar nestas notas ainda preliminares, implicando em novos ou antigos temas aos quais os antropólogos se dedicaram na década de 80, dentre eles outros estudos referidos à homeopatia, aos sistemas 
religiosos de cura, às doenças mentais, à Aids, à esquistossomose, ao corpo, à sexualidade e reprodução, às estratégias de cura, à relação da clientela com os serviços de saúde, às representações dos profissionais de saúde, além das novas propostas do recurso da metodologia antropológica na avaliação dos serviços de saúde.

Apesar do caráter preliminar e inacabado deste texto, baseado em pesquisa bibliográfica ainda em andamento, não poderia furtar-me de contribuir para o debate sobre antropologia e saúde, ensejado nesta coletânea.

Para concluir, resta afirmar que, inegavelmente, a antropologia na década de 80 aproximou-se do tema saúde, doença e dos distintos sistemas de cura, o que pode significar que ela vem refletindo sobre questões oferecidas pela sociedade, mesmo quando resiste em recortar objetos específicos, uma vez que os fenômenos saúde, doença e cura ultrapassam a dimensão restrita biologica, como pode ser visto nos vários estudos. Por tradição, a antropologia opôs-se ao modelo médico, mas nessa década, pelo menos no Brasil, assumiu-o como objeto de reflexão, uma vez que o campo dos saberes e práticas ditos "populares" ou "alternativos" sempre mereceram a atençāo dos antropólogos. Talvez, mesmo diante dos novos saberes e práticas de cura que se mesclam, recriam ou se impõem, restem ainda desafios à pesquisa, tanto quanto das multiplicidades - nuances dos distintos saberes e práticas consolidados no sistema médico alopático - e das novas modalidades de cura recriadas em nossa sociedade. 


\section{REFERÊNCLAS BIBLIOGRÁFICAS}

ALVES, S. R. P. (1982). Do outro lado do muro: estudo sobre representaçāo de doença mental em uma populaçāo favelada do Rio de Janeiro. Rio de Janeiro. Dissertaçāo de mestrado, Instituto de Psiquiatria. UFRJ.

AUGE, M. L'Anthropologie de la Maladie. L'Homme, n" spécial Anthropologie. Etat des lieux. Paris: Navarin/Livre de Poche, pp. 77-88.

BOLTANSKI, L. (1979). As classes sociais e o corpo. Rio de Janeiro, Graal.

BRANDÃO, C. R. (1981). Plantar, Colher e Comer. Rio de Janeiro, Graal.

BUCHILLET, D. (1991). A Antropologia da Doença e os Sistemas Oficiais de Saúde. In Buchillet, D. (org.) Medicinas Tradicionais e Medicina Ocidental na Amazônia. Belém. Edições CEJUP: 21-44.

CANESQUI, A. M.(1968). Antropologia e Alimentaçāo. Revista de Saúde Pública 20 (3): $207-16$.

-. (1976). Comida de Rico, Comida de Pobre: um estudo sobre alimentą̧ão num bairro popular. Campinas. 1976. Tese de Doutoramento. FCM-UNICAMP.

CARDOSO, M. D. (1986). Médicos e Clientela: sobre a assistência psiquiátrica à coletividade. Campinas. Tese de Mestrado. IFCH-UNICAMP.

CARRARA, L.S. (1989). Crime e Loucura: o aparecimento do manicômio judiciário na passagem do século. Rio de Janeiro. Tese de Mestrado. Museu Nacional - UFRJ.

CORREA, M. (1982). As llusões da Liberdade. A Escola de Nina Rodrigues e a Antropologia no Brasil. São Paulo. Tese de Doutoramento. FFCL-USP.

- (1982). Antropologia \& Medicina legal - variações em tomo de um mito. In: vários autores, Caminhos cruzados. São Paulo, Ed. Brasiliense.

COSTA, A .M. (1980). Riqueza de Pobre: um estudo em antropologia da saúde. Brasillia. Tese de Mestrado. UnB.

D'AMORIN, S. C. (1984). A seduçāo na umbanda e a inoperância terapêutica da psicanálise. Anais da 36 Reunião da SBPC. São Paulo.

DANIEL, J. M. P; CRAVO, V. Z. (1989). O valor social e cultural da alimentação. Boletim de Antropologia 2(4):70-83.

DOUGLAS, M. (1976). Pureza e perigo. Sāo Paulo, Ed. Perspectiva.

DUARTE, L .F. (1986). Da vida nervosa nas classes trabalhadoras urbanas. Rio de Janeiro. Jorge Zahar Editor/CNPq.

- (1988). A representação do nervoso na cultura literária e sociológica do século XIX e começos do século XX. 16 Reuniāo da Associação Brasileira de Antropologia. Campinas.

DURHAM, E. R. (1986). A Pesquisa Antropológica com População Urbana: problemas e perspectivas. In Cardoso, R. (Org.) A A ventura Antropológica. Teoria e Pesquisa. Rio de Janeiro. Editora Paz e Terra: 17-37. 
EVANS-PRITCHARD, E. E. (1937). Witchcraft, oracles and magic among the Azande. Oxford, Claredon Press.

FERNANDES, R. C. (1990). Religiōes Populares: uma visão parcial da literatura recente. In Boletim Informativo Bibliográfico $n^{\circ} 15$ a 19: 238-273.

FORTES, M. (1976). Foreword. In London, J. B. (Org.). Social Anthropology and Medicine. London, London Academic Press.

FRANKENBERG, R. (1980). Medical Anthropology and Development: a theoretical perspective. Social Science and Medicine. B 14: 197-207.

GLUCKMAN, M. (1973). Custom an Conflict in Africa. Oxford, Basil Blackwell.

GREAT BRITAIN.(1968). Social Science Research Council Review. Research in Social Anthropology: 57-59.

GUEDES, S. L. (1974). Umbanda e Loucura. In Velho, G. (Org.) Desvio e Divergência. Uma Critica da Patologia Social. Rio de Janeiro. Zahar Editores: 82-98.

GUIMARĀES, A. Z.(1979). Relatório Final do Grupo de Pesquisas de Ciências Sociais e Nutriçāo. Rio de Janeiro, FINEP/INAN/IBGE, vol. 4.

IBAÑEZ-NOVIÓN, M. A. \& TRINDADE, S. J. (1978). O mundo composto: o caso do noroeste mineiro. In Anuário Antropológico/77. Rio de Janeiro, Tempo Brasileiro.

KLEINMAN, A. (1978). Concepts and model for the comparison of medical systems as cultural systems. Social Science and Medicine, B 12: 85-93.

LAPLATINE, F. (1986). Antropologia da doença. Såo Paulo, Martins Fontes.

LINS E SILVA, T. (1979). Os curupiras foram embora: um estudo sobre alimentação e reprodução da força de trabalho entre camponeses paranaenses. In Guimarães, A. Z. Relatório Final do Grupo de pesquisas de Ciências Sociais e Nutrição. Rio de Janeiro, FINEP/IBGE. vol. 4.

LOUGON, M. (1987). Os caminhos da mudança. Alienados, alienistas e as desinstitucionalização da Psiquiatria. Rio de Janeiro. Tese de Doutoramento. Museu Nacional. UFRJ.

LOYOLLA, M.A. (1987). Medicina Popular: Rezas e Curas do Corpo e Alma. Ciência Hoje 6 (35): 34-43.

-. (1983). Médicos e Curandeiros. Conflito Social e Saúde. Rio de Janeiro. Difel.

- (1987). Uma medicina de classe média: idéias preliminares sobre a clientela da homeopatia. Cadernos do Instituto de Medicina Social I (1): 45-72.

MAGNANI, J. G. (1980). Doença e Cura na Religiāo Umbandista. Campinas. UNICAMP (mimeo).

- (1980). Doença e Cura na Religião Umbandista: subsídios para uma proposta de estudo comparativo entre práticas médicas alternativas e medicina oficial. São Paulo, mimeo.

-. (1986). Umbanda. São Paulo, Editora Ática. 
MARCIER, M .H. F. C. (1977). Padrões alimentares de um grupo de camponeses numa situação de expropriação no Estado do Maranhāo. In Guimarães, A. Z. Relatório Final do Grupo de Pesquisas em Ciências Sociais e Nutrição. Rio de Janeiro, Museu Nacional.

MARIN, M. C. (1977). Emprego e serviço: estratégia de trabalho e consumo entre operários de Campina Grande. In Relatório do Grupo de Pesquisa do Museu Nacional; projeto Hábitos Alimentares em Camadas de Baixa Renda. Rio de Janeiro, Museu Nacional.

MAUÉS, H. R.; MAUÉS, A. G. (1983). O modelo da "reima": representaçōes alimentares em una comunidade amazônica. Anuário antropológico. Rio de Janeiro, Paz e Terra.

MAUÉS, H. R.; MAUÉS, M. A. (1980). O Folclore da alimentação: tabus alimentares da Amazônia. Belém.

MELATTI, J. C. (1984). A Antropologia no Brasil: um roteiro. Boletim Informativo Bibliográfico de Ciências Sociais, $n^{\circ}$ 17: 1-92.

MINAYO. M. C. S. e SOUZA, H. O. (1985). Na dor do corpo e grito da vida. In COSTA, N. R. et al. (org.) Demandas populares, políicas públicas e saúde. Vol. II. Rio de Janeiro. Petrópolis/Vozes: 75-101.

MINAYO. M. C. S. (1992). O Desafio do Conhecimento. Pesquisa Qualitativa em Saúde. Sāo Paulo. HUCITEC - ABRASCO.

—. (1988). Saúde-Doença: numa concepção popular de etiologia. Cadernos de Saúde Pública 4(4) :363-381.

MONTEIRO, D. T. (1979). Igrejas, Seitas e Agências: aspectos de um ecumenismo popular In Valle, E. c Quciroz, J. J. (Org.) A Cultura do Povo. São Paulo, Cortez e Moraes/Editora da Universidade Católica: 81-117.

MONTERO, P. (1985), Da Doença à Desordem. A Magia na Umbanda. Rio de Janeiro. Graal.

-. (1986). Magia e Pensamento Mágico. São Paulo. Editora Ática.

—. s/d, A Cura Mágica da Umbanda. ANPOCS, Grupo Sociologia da Cultura Brasileira, (mimeo).

-. s/d, Medicina Popular e Relações de Poder. (mimeo).

MOTT, Y. T. (1979). Caridade e Demanda. Dissertação de Mestrado. IFCH, UNICAMP.

NEVES, D.P. (1984). As curas religiosas e a idealização da ordem social. Niterói. UFF.

NEVES, D. P. \& SEIBLITZ, Z. (1984). Saúde e Doença: merecimento e castigo. Revista O Médico Moderno. Agosto ; 57-74.

NUNES, E. D. (1992). As Ciências Sociais em Sauide: reflexöes sobre as origens e a construção de um campo de conhecimento. Saúde e Sociedade 1(1): 59-84.

OLIVEIRA, E. R. (1983). Doença, Cura e Benzedura: um estudo do oficio de benzedeira em Campinas. Campinas. Dissertação de Mestrado. IFCH-UNICAMP. 
-. (1983b). O que é Medicina Popular. Såo Paulo. Brasiliense.

OLIVEIRA, R. C. (1985). O que é isso que chamamos de antropologia brasileira? Rio de Janeiro. Anuário Antropológico: 227-246.

OLIVEN, R. (1985). A Antropologia e a Cultura Brasileira. Boletim Informativo de Ciências Sociais, $n^{2}$ 27:74-88.

PEIRANO, M. G. S. (1977). Proibiçōes alimentares numa comunidade de pescadores. Brasilia. Dissertação de Mestrado. Universidade de Brasília.

PERELBERG, R.J. (1980). As Fronteiras do Silêncio. Um estudo de desvio e ritualização. Rio de Janeiro. Adrianú.

QUEIROZ, M. S. (1980b). Curandeiros do mato, curandeiras da cidade e médicos: um estudo antropológico dos especialistas em tratamento de doenças na regiäo de Iguape. Ciência e Cultura, 32:31-47.

-. (1980a). Feitiço, mau-olhado e susto: seus tratamentos e prevençōes na aldeia de lcapara. Religiăo e Sociedade (5), 131-60.

- (1984). Hot and cold classification in traditional Iguape medicine. Ethnology 23(1): 63-72.

- (1978). Representa̧̧ões de doenças e instituiçōes de cura numa aldeia de pescadores. Campinas 1978. Tese de Mestrado. IFCH, UNICAMP.

QUEIROZ, M. S. e CANESQUI, A. M. (1986). Contribuição da Antropologia à Medicina: uma revisāo de estudos no Brasil. Revista de Saúde Pública. Sāo Paulo. 20(2):141-51.

RODRIGUES, N. C.C. (1984). A Casa da Bênção de Deus: experiência social e prática religiosa em Brasilia. Brasilia. Tese de mestrado. UnB.

SOARES, B. M. (1988). A homeopatia como espelho da vida. Rio de Janeiro, Tese de Mestrado. Museu Nacional. UFRJ.

THOMAS, L. V. (1986). Prefácio. In LAPLATINE, F. Antropologia da doença. São Paulo, Martins Fontes: 5 .

VELHO, G. (1984). Desvio e Divergência: uma crítica da patologia social. Rio de Janeiro. Zahar.

VELHO, O. G. (1979) A Universidade e a Antropologia no Brasil Hoje. Encontros com a Civilização Brasileira. 17:169-179.

-. (1977). INTRODUÇÃO. In Relatório do Grupo de Pesquisa do Museu Nacional; projeto Hábitos Alimentares em Camadas de Baixa Renda. Rio de Janeiro, Museu Nacional.

VENÂNCIO, A. T. (1990). Sobre a nova psiquiatria no Brasil: um estudo de caso do hospital-dia do Instituto de Psiquiatria. Tese de Mestrado. Rio de Janeiro. Museu Nacional. UFRJ.

WARTOVSKY, M. W. (1982). Editorial. Journal of Medical Philosophy 1(3):265-72.1976. Citado por WORSLEY, P. Non-Western Medical Systems. Annual Review of Anthropology. Vol. 11:327. 
WOORTMANN, K. (1978). Hábitos e ideologias alimentares em grupos de baixa renda: relatório final de pesquisa. Brasília, Universidade de Brasflia.

YOUNG, A. (1982). The Anthropologies of Illness and Sickness. Annual Review of Anthropology (11): 257-85. 


\title{
ENTRE CIENTISTAS E BRUXOS \\ Ensaio sobre os Dilemas e Perspectivas da Análise Antropológica da Doença
}

\author{
SÉrgio Carrara
}

"Por felicidade, a arte mágica não gesticulou sempre no vazio, pois tratou materiais, fez experiências reais e até descobertas"

Marcel Mauss (1974[1902-3]:169)

"...o conhecimento pode ser, ao mesmo tempo, objetivo e subjetivo..."

Lévi-Strauss (1976[1962]:60)

\section{INTRODUÇÃO}

Recentemente, no âmbito do I Encontro Nacional de Antropologia Médica, fui convidado a reflctir sobre a questão do método na análise antropológica da doença. $\mathrm{Na}$ verdade, o que me interessava não era discutir as propricdades ou impropriedades, vantagens ou perigos deste ou daquele método particular, utilizado em pesquisa, que poderia ser enquadrado cm uma possivel Antropologia Médica. Muito mais geral, meu interesse sc voltava antes para o modo como têm sido concebidos ou construídos os objetos de reflexão que usualmente são atribuidos a essa especialidade antropológica. Desde logo, devo dizer que, a cla, penso serem ainda mais aplicáveis as críticas que, em 1927, Marcel Mauss fazia às sociologias do Dircito, da Moral, da Religiāo, insatisfatórias mas não-descartáveis naquele momento. Delas, diz Mauss que "correspondem demais às divisões mais atuais, mais efêmeras do que se crê, do trabalho social modemo, das atividades de nossas sociedades". Que trazem "profundamente a marca do nosso tempo, aquela de nossa subjetividade" e que, portanto, "quadram-se mal com a vida daquelas socicdades que dividiram de outra forma seu trabalho ou que um dia os dividirão de mancira diferente da nossa". Por screm, scgundo cle. "dcmasiado empiricas em certos pontos", tais cspecialidades "retalham, dividem, e, dividindo demais, isolam demais; no fundo, abstracm e dão 
da realidade uma imagem partida, tuncada" (Mauss, 1981[1927]:56). Atualmente, parece que nåo nos incomodam tanto as "imagens partidas da realidade", mas talvez seja importante hoje, ainda mais que na epoca de Mauss, reaproximar dominios, costurar retalhos, pensar de modo menos abstrato. Mais que isso, talvez valha a pena recuperar um pouco da crenca na possivel objetividade da ciência. Crença que animava todo o texto de Mauss e que, para muitos, nesses nossos tempos pós-foulcautianos, pode certamente parecer ingênua e obsoleta.

É certo que, empiricamente, os temas abordados pela Antropologia Médica são bastante diversos e poderiam muito bem ser classificados em várias outras subáreas disciplinares. rocortadas a partir de outros critérios: Antropologia do Corpo. da Pessoa. do Mal. do Desvio, Simbólica. Cognitiva. Política. da Ciência. da Docnça. do Dircito ou da Religiảo. Entretanto. a realizaçäo mesma de um encontro brasilciro de Antropologia Módica indica a cxistência de uma comunidade (ou ao menos de uma rede de cspecialistas) que, a cxemplo do que já aconteceu em outros paiscs, começa a se consolidar. revindicando para si (ou accitando de bom grado) uma identidade singular no seio das chamadas ciências humanas e sociais. E, como qualquer comunidadc. esta parcec também reclamar uma gencalogia, uma tradiçăo e um território mais ou menos delimitado para desenvolver suas atividadcs.

Confesso que scria um péssimo informane para um antropólogo que se propusesse a estudar mais detidamente tal comunidade ou rede hoje no Brasil. A meu favor. tenho talvez o seu caráter ainda um tanto disperso, fluido e sua frágil institucionalização. De todo modo, daria a clc o próprio programa desse I Encontro Nacional (ver anexo), que năo deiva de scr, ao mesmo tempo. um interessantc "mapa de aldcia" (com suas relaçð̃es sociais e hicrarquias, suas instiluiçőes mais importantes, suas principais alianças intra e extradisciplinares, etc.) $\mathrm{c}$ um importante "censo das principais atividades produtivas" (embora um tanto vago quanto às "técnicas de produçăo"). Além de informaçöes preciosas sobre a morfologia c fisiologia de uma comunidade cientifica emergente, ele oferece um extenso levantamento dos "dominios" por ela reivindicados. Por isso, posso muito bem utilizá-lo aqui como guia para uma análise preliminar do movimento mais global que. em termos das escolhas temáticas e metodológicas, vemos desenrolar-sc nesse subcampo da Antropologia Social.

\section{MAPEANDO DOMINIOS}

Uma leitura superficial do programa do I Encontro Nacional de Antropologia Médica realizado no Brasil revela que os "dominios" da especialidade comportam alguns "territórios" de "ocupação" mais antiga e outros que eståo apenas em vias de serem "abertos" ou "anexados". Somente uma paciente arqueologia (muito mais sofisticada do que a que posso emprecnder nesse momento) poderia fazer com que tais "territórios", justapostos indistinta e sincronicamente na enumcraçăo serial das diversas sessőes, pudesscm se separar, revelando a historicidade que lhes é própria e as "guerras" ou "conflitos", 
"alianças" ou "acondos" que permitiram sua "integracăo" mais ou menos definitiva à Antropologia Social.

Tomemos tais "domínios" apenas do ponto de vista de sua dimensăo mais empírica, ou seja, a partir dos temas que circunscrevem. Comecando pelos mais antigos, temos o "mundo primitivo", objeto primordial da Antropologia Social, que emerge em duas sessores distintas (Populaçøes Indigenas e Sistemas Médicas e Grupos Étnicos e Práticas Mlédicas). A se crer nos títulos dos trabalhos apresentados, tais sessoes são dedicadas quase exclusivamente à discussäo em torno das "conceppöles"/ representaçes sociais" e do processo de "construção sociocultural" da doença. Estło voltadas, portanto, basicamente para análise de cosmologias.

Ao lado deste tema, por ordem de precedência histórica, vemos o já clássico "mundo das classes populares", em cujo âmbito, contrastivamente, se revela um marcado interesse nos rituais e práticas mágico-religiosas (Sistemas Religiosos e Tratamento, e Sistemas Alternativos e Tratamento, e mais discretamente em Sistemas M(édicos Comparados). Até onde sei, foi em meados do século XX que, através da nocaa de folk-culture e dos "estudos de comunidade", os antropólogos puderam dar esse importante passo na direcão da análise do seu próprio universo sociocultural. Mesmo estando inicialmente voltados para aquilo que. em suas margens (no mundo nural ou nas periferias dos grandes centros urbanos), ele ainda continha de não-moderno. de "primitivo".

Quando se restringiam ao estudo do "mundo primitivo", dentro ou fora de suas próprias socicdades, os antropólogos se debruçavam sobre um conjunto de representaçðes e de práticas sociais aparentemente semelhantes ao que se poderia chamar, do ponto de vista da medicina, de doença, saúde ou ato terapêutico. Porém, ao serem submetidos à análise, logo revelavam-sc que eram dificilmente discerníveis de outras representaçðes e práticas, comumente classificadas ou de mágico-religiosas, ou de jurídico-politicas. Nesse ponto. como aliás se evidencia no clássico trabalho de Evans-Prilchard sobre a bruxaria Zande (Evans-Pritchard:1978), uma Antropologia Médica podia ser tudo. menos antropologicamente bem fundamentada. pois, para grande parte da populaçăo do plancta, aquilo que chamamos de doença ou acidente, partilhava ao mesmo tempo de características daquilo que. para nós, seria um crime ou um ataque sobrenatural. Fatos a um só tempo sociais, naturais e místicos, como abordá-los adequadamente a partir de uma disciplina que parecia estilhaçá-los a priori, fazendo com que uma de suas dimensðes se sobrepujasse às outras, tão ou mais importantes do que ela?

Mas. como se pode ver através do programa do I Encontro Nacional, a Antropologia Médica não reivindicou apenas o estudo de certos fenômenos atinentes ao "mundo primitivo". A partir desse tema básico, outros foram surgindo progressivamente. Mantendo a cronologia dessa superficial arqueologia já na segunda metade do século XX, através dos estudos urbanos, emerge na Antropologia brasileira a reflexão sobre grupos sociais fortemente marginalizados. Dois temas importantes se delincam então: de um lado, a loucura e, de outro, o desvio, especialmente os desvios do comportamento sexual. Momento fundamental da história recente da própria Antropologia Social como um todo, em que ela intensifica sua reflexão sobre objetos antes estudados predominantemente pelas ciências médicas, especialmente por suas vertentes psicológicas. Em larga medida, fenômenos como a loucura ou a sexualidade eram explicados a partir de uma ordem de 
causalidade biológica ou natural, apesar de se adequarem mal à concepço geral dos fenômenos patológicos que se estabelece a partir do século XIX. Talvez tenham sido mais facilmente "antropologizáveis" justamente por terem sempre permanecido nas franjas do saber médico, objetos de intensas disputas entre neurologistas, psiquiatras, psicanalistas, psicólogos, mas também juristas, pedagogos, moralistas e sociólogos. De todo modo. o que importa ressaltar aqui é o fato de a análise antropológica ter se deslocado de realidades que, no contexto das culturas não-ocidentais e nåo-modernas, pareciam homólogas ao que chamamos de Medicina, saúde e doença, para incursionar em vastos territórios antes amplamente monopolizados pelas ciências biomédicas, questionando a própria fundamentaça natural dos fenômenos ai observados.

No I Encontro Nacional de Antropologia Médica, além de uma presença mais discreta na mesa sobre Saúde Urbana, a loucura merece duas mesas: uma delas intitula-se Antropologia e Saúde Mental e a outra Etnopsiquiatria e Etnopsicologia. Já o tcma da sexualidade parece ter sofrido importante inflexão: abandona-se a discussăo do estigma e das identidades sociais desviantes e se enfatiza a discussão sobre gênero e reprodução. Inflexão que parece consolidar as alianças entre antropólogos e demógrafos e instaurar outras novas, com especialistas das árcas de saúde reprodutiva (tcm-se duas mesas sobre a questão: Gènero e Saúde e Representações Sexuais e Práticas Médicas).

Mas a grande novidade no campo da Antropologia Médica parece ser a emergência da análise de fenômenos que até muito recentemente eram encarados (sem grandes conflitos) como matéria cxclusivamente médica, como as endemias (na mesa Antropologia e Doenças Endémicas) e epidemias. muito especialmente a AIDS (em duas mesas: Antropologia e AIDS Ie II). Através desses objetos, parece que hoje se estreitam as relaçōes entre a Antropologia. de um lado. e Saúde Pública e Epidemiologia, de outro. E me pergunto mesmo sc, na ausência dessas novas alianças, teria sido possivel a realização no Brasil de um encontro dessa envergadura.

Eu nåo sabcria dizer exatamente de que caracteristica transcultural, suficientemente abstrata e geral, tais temas comungam para que pudéssemos classificá-los em uma rubrica menos etnocêntrica (ou ao menos mais heuristica) do que a de Antropologia Mćdica ou da Saúde. Alguns têm $\mathrm{cm}$ comum apenas o fato de serem facilmente assimilávcis às nossas próprias representą̧ðes dos fenômenos patológicos ou de se assemelharem às práticas que utilizamos para enfrentar as doenças. Outros, entretanto, partilham apenas o fato dc. antes de terem passado a também nos "pertencerem" legitimamente, terem figurado na seara dos saberes biomédicos e psicológicos.

Apesar dessas dificuldades relativas à definição mesma do objelo precipuo da Antropologia Médica, podemos facilmente perceber a trajetória global que, em nível de escolhas temáticas, se descnhou quanto ao referente sociológico. Caminhou-se da "periferia" ao "centro", das sociedades näo-ocidentais à nossa própria sociedade. E de "baixo" para "cima", ou seja, das representaç̋̄es e práticas chamadas de mágico-religiosas, mantidas por classes dominadas, subordinadas, etc., para a análise da ciência e das elites intelectualizadas de nossas próprias sociedades. Além disso, quando se toma como objeto a ciência ou a Medicina, a trajetória da refiexão parte do que é socialmente considerado mais "espiritual", "psicológico", ou "moral" (a loucura, a homossexualidade, etc.) para o mais "orgânico", "físico" e "material" (doenças como AIDS, malária, etc.). 
Como é visivel, tal translação em nível dos objetos empíricos implicou uma enorme expansão dos dominios da Antropologia Social nas últimas dćcadas. Em partc. tal expansão foi possibilitada por um movimento corrclativo no nivel das posturas teórico-mctodológicas que importa agora considerar. A história dessa cxpansão ć, cm certo sentido, a própria história da disscminação de uma abordagem que tem sido chamada de "construcionismo", e que, com freqüència cada vez maior. vem sendo aplicada à análisc da produção científica em geral, especialmente a da árca biomédica que, diga-se de passagem. tcmos conscguido transformar com bastante sucesso em "objcto" da nossa própria "ciência".

\section{RETRAÇANDO CAMINHOS}

De antemão. reconheço que a discussão que se scgue talvez interesse sobretudo àqueles de nós que, como cu. vêm refletindo sobre uma docnça particular ou sobre a Medicina cientifica $\mathrm{cm}$ geral. c que. por estarem institucionalmente alocados $\mathrm{cm}$ cspaços híbridos (do ponto de vista da tradicional partiça das disciplinas científicas) c de ocupação recente - instututos. departamentos ou escolas de Medicina Social. Medicina Preventiva, Saúdc Pública. cıc.-, tèm de manter um diálogo nem scmpre fácil com profissionais oriundos de áreas de reflexão comumente designadas como "ciências duras". Profissionais que, diga-se de passagem, ora são nossos concorrentes, ora nossos aliados, ora nossos objctos, ora nossos intcrlocutores.

A chamada abordagem "construcionista" tem já uma história que podemos seguir suscintamente através de dois trabalhos mais ou menos recentes. Refiro-me à extensa revisão de Kevin Whitc publicada há dois anos na Current Sociologv, intitulado "Sociology of health and illness" (White. 1991). E a um texto um pouco mais antigo. de Claudine Herslich, intitulado "Medicina modema e busca de sentido: a doença como significante social", publicado cm una coletânea que a autora organizou juntamente com o antropólogo Marc Augé (Herzlich, 1984). Ambos os trabalhos sc situam na perspectiva "construcionista". cmbora com diferentes graus de adesão aos seus principios básicos. Herzlich mantém uma posição mais critica e aparentemente mais conservadora, enquanto que o trabalho de White pode ser lido como uma espécic de manifesto "construcionista".

Whitc faz. uma história das idćias bastante tradicional, apresentando sem qualquer contcxtualização socio-histórica três grandes paradigmas para a abordagem das questões rclativas à saúde e a docnça. Inicia com Parsons, passa pela abordagem marxista. com sua variantc feminista, e acaba no "constnucionismo". Para ele, na passagem de um modelo a outro, progressivamente e com uma grau de "sucesso" cada vez maior. os cientistas sociais puderam questionar a própria objetividade do pensamento médico, destruindo suas pretensores positivistas. Conforme diz: "Parsons, to locate the power of the medical profession to prevent opportunistic failure to fill social roles on the part of actors, grounds the status of medicine in its knowledge of biology. The materialist basis of Marxist epistemology (and Marxist feninism) means that Marist analysis leaves a large residual category of human activitics which it sees as naturally defined. It is only the constructionist perspective, 
developing out of Fleck and then Foucault's work that attempts to explain all catcgories of understanding health and illness in a sociological framework" (White, 1991:2).

Processo semelhante de "desnaturalização" progressiva das categorias nosológicas foi também detectado por Herdich. Ao se referir à sociologia americana da década de cinqueenta, a autora diz que, inicialmente, "tomando como objeto a doença, os sociólogos assumiam e accitavam plenamente as concepcōes médicas do fato patológico". Para eles, - saber médico era uma "decodificaça do orgânico que o desenvolvimento cientifico tomava mais precisa e segura a cada dia". Aceitando a definição médica da doença, enquanto processo bioquimico que afeta o corpo individual, apontavam complementarmente para sua dimensăo social: o contexto organizacional e de relação da doença. Nesse momento, como diz Herzlich, ao sociólogo cabe a tarefa de definir o que se passa antes, depois e em tomo de uma realidade medicamente definida: "trabalha sobre a doença enquanto conduta social. o status social e o papel do docnte na nossa sociedade, as variáveis que determinam scu comportamento e as normas que lhe dão forma e suas relą̧ðes com a instituiçăo médica" (White,).

Passando ao largo da abordagem marxista e sua "crítica político-econômica" à medicina (Ehrenreich. 1978), Herzlich identifica uma corrente mais recente. no seio da qual, conforme diz, a própria "realidade do fenômeno patológico. a verdade do saber médico, e a eficácia da sua prática são igualmente postos entre parêntescs" (Herzlich, 1984:11). A medicina não realiza mais a pura decodificação do orgânico ou da doença mas sua construção a partir das categorias cognitivas socialmente dadas que manipula. Assim, como diz Herzlich. procura-se "mostrar de que mancira a medicina se origina do social e produz o social". Ainda segundo ela. tal abordagem teria se restringindo inicialmente "às áreas mais fáccis. dentro de sua perspectiva. mas também menos fecundas, da doença mental ou dos fenômenos da medicalização" (Herzlich, 1984:12).

White sistematiza mais claramente as bases do "construcionismo" que ele defende, colocando-o um tanto normativamente como condição sine qua non para uma abordagem sociologicamente válida dos fenômenos patológicos. Para ele, três premissas são fundamentais:

1. that medicine is not a natural science, but rather acts to transform what are statments of values into apparent statements of fact:

2. that professions are the outcome of social and political struggles, rather than being shaped by natural objects of which we can have scientific knowledge;

3. and medical belief systems are specific to the society which produces them (White, 1991:2).

Assim, onde antes tinhamos natureza, temos agora relaçðes de poder, de um lado, e sistemas de crenças, de outro. Podemos reduzir a ciência ou a Medicina à cultura ou ao poder, mas é interditado ceder às suas pretensőes, reduzindo-a à natureza. Efetivamente, para Whitc, os sociólogos que trabalham com as questores referentes à doença, à Medicina ou ao conhecimento cientifico em geral devem romper "with the idea that facts do exists in a determinate way, and move to a perspective which views them - as Lukacs argued as the product of their own socio-historical epoch" (White, ). Subjacente a tal perspectiva, como reconhece o próprio White, a idćia de que a ciência é antes de mais nada uma 
linguagem. E, segundo diz, como a linguagem é social, 'tudo o que é convencionado pela linguagem deve (must) ser social em sua origem. Assim, a partir dessa perspectiva, o trabalho das ciências naturais reduz-se a um eterno e, reconheca-se, falscador processo de naturalizaç̃o através da linguagem do que é social (experiências e idcologias), ou como diz White, a "transformation of conjectural statements which are linguistically qualified into statements of "fact" formulated without linguistic qualification" (White, 1991:81). Por seu lado, o papel da Sociologia e da Antropologia parece ser restituir aos fenómenos biológicos sua verdadeira natureza social. Cobrar o que lhes pertence de direito e, libertando as coisas de sua pesada materialidade, destruir a indevida naturalizaça empreendida pela ciência.

Para White, os pais fundadores dessa perspectiva. como vimos, seriam Ludwik Fleck e Michel Foucault e os "ancestrais míticos", Durkheim e Mauss. Scgundo diz "the classical statement of the argument for the social production of the categories of nature is of course to be located within Emilc Durkheim's sociology of knowledge, as developed in The Elementary Forms of the Religious Life and (with Marcel Mauss) in Primitive Classification (Whitc. 1991:9).

Como pode se inferir facilmente, com o "construcionismo", as relą̧ð̋es entre os cientistas sociais e os médicos alteraram-se profundamente. Foi a própria lcgitimidade do saber médico, ao menos como os médicos a concebiam, que foi colocada cm questăo. Foi - monopólio que mantinham sobre inúmeros fenomenos que parece ter sido definitivamente rompido. pois o que estava (e ainda está) em jogo no campo académico cra a afirmação da preeminência do social. do politico e do cultural sobre o orgánico ou natural. Uma das conseqüências mais evidentes desse emprecndimento crítico foi, sem dúvida, a enorme expansão disciplinar e institucional que as chamadas ciências sociais (especialmente a Antropologia Social) experimentaram nas últimas décadas. penctrando em espaços antes restritos aos profissionais da árca de saúde.

Apesar de não cxplorar os dados que apresenta, como o farei aqui, Herzlich, no artigo citado, nos of crece algumas pistas interessantes para compreendermos sociologicamente o sucesso desse emprecndimento, dessa mudança na abordagem das ciências sociais no sentido de uma "desmaterialização" ou "desnaturalizaçăo" da doença. A partir de uma pesquisa realizada na França na década de sessenta, Herzlich mostra como, naquele momento, no seio das classes médias, a doença era vista preferencialmente como fruto de uma modernidade agressiva c opressora (poluiçæo, al imentaçăo alıcrada c química, banulho, etc.). E, conforme diz Herzlich. a Medicina científica 'passou a ser "uma das expressð̃es privilegiadas" dessa modernidade exageradamente cientificista e tecnicista. colocando, a cada progresso realizado, mais perigos à saúde dos individuos do que os conseguia exorcizar. Sem explicitar as necessárias conexóes com a própria mudança no paradigma sociológico que desvela inicialmente em seu texto, Herelich demonstra com precisão ter sido a partir da década de 60 que "a doença e a medicina sc inscrevem numa sćrie de dilemas em que se cxpressa nossa relação ambígua com a evolução científica e social". Ressalta que se "o desenvolvimento dos conhecimentos e o crescimento das intervençöes médicas reforçaram nosso dominio dos fenômenos do corpo", "paralclamentc, aumentaram nossa insatisfação diante desses limites, nossa intolcrância para com a incenteza, para com o acaso que continua a nos rondar" (Herdich, 1984:31). 
Anos antes. Ehrenreich ressaltava o modo pelo qual, no contexto americano, a "critica cultural" da Medicina, que se avolumou a partir dos anos sessenta, se ligava diretamente aos emergentes movimentos pelos direitos civis de mulheres e de negros. Tais movimentos teriam inspirado uma enome produçă acadêmica para qual, em resumo, "sociais" que expressame reforçam as hierarquias de classe, raca, sexo e idade, estimulando o isolamento individual e a passividade frente à ordem social (Ehrenreich. 1978:15). Como sabemos, a Antropologia Social teve papel ativo nesse contexto. Ao lado dos "doentes", discutiu a patologizacão, $\mathrm{e}$ ao lado dos marginalizados, a marginalizacão. Através de sua reflex 3̂o instrumentalizou a aça de diferentes grupos sociais que lutavam por uma sociedade mais tolcrante e plural.

É como parte desse contexto mais global que a disseminaçáo do chamado "construcionismo" deveria ser analisado. A crise da medicina durante os anos 60 e 70 foi apenas um dos aspecto da desconfiança gencralizada que recaiu sobre o pensamento científico em geral. ao menos, sobre as prerrogativas de objetividade e universalidade que se outorgava e que lhe haviam sido socialmente reconhecidas ao longo do século XIX e primeira metade do século XX. Com o recuo da autoridade médica e científica. novos espaços foram abertos e os antropólogos soubcram ocupá-los. Na vaga da contracultura, a Antropologia Social aparecia entăo como a guardiă de um tesouro de saberes desprezados ou destruídos por uma modernidade arrogante que se julgava detentora da Verdade. Além disso, em sua prática com os povos primitivos, já havia demonstrado que. senão falavam da natureza em si (o que era evidente quando se tratava de "sclvagens"), as representaçöes sobre o mundo natural cram terrivelmente loquazes em relação à cultura e à organizaçăo social que as produzia. Além de logicamente cocrentes (faziam parte de sistemas bem articulados), eram socialmente funcionais.

Atualmente. no bojo da crise que atinge a Antropologia Social a partir da critica aos limites da abordagem relativista que a tem caracterizado. o próprio "construcionismo" comesa a gerar apreensões e angústias. Apesar de aconselhar a cxtensão da abordagem "construcionista" para doenças "mais nitidamente ongânicas e graves" ou "aos casos mais sérios de doença mais somática", Herdich já fazia uma importante ressalva quanto ao fato de cssa abordagem "limitar-se a tratar a medicina sem referência à positividade de seu saber ou à cficácia de sua prática, como simples resposta simbólica ou como pura idcologia", o que, segundo dizia, mesmo esclarecendo certas funçð̋es sociais da medicina, não pode elucidar o scu funcionamento (Heralich. 1984:12-13). Recentemente. esta mesma insatisfaçăo foi ainda mais intensamente cxplicitada pelo historiador Charles Rozemberg. Para ele, estamos cntrando $\mathrm{cm}$ um periodo pós-relativista em larga medida. devido ao impacto da AIDS, cuja importância para a Antropologia pode bem ser avaliada pelo espaço que ocupa nesse I Encontro Nacional de Antropologia Mćdica. Para Rosemberg. "gay leaders who had for decades urged the demedicalization of homosexuality now find their community anxiously attuned to the findings of virologists and immunologists. This is not to say that the social perceptions of AIDS and the definition of policy choices are not shaped by pre-existing social attitudes; the deviant are still stigmatised. victims still blamed. But the biomedical aspects of AIDS can hardly be ignored: it is difficult to ignore a discase with a fatality rates approaching 100 pereent. AIDS has, in fact, helped create a new consensus in regard to disease, one that finds a place for both biological and social factors and 
emphasises their interaction" (Rosemberg, 1988:14). Se, conforme diz Rosemberg, a AIDS tem mostrado a inadequaçăo de uma abordagem que busca compreender e controlar a doença nos limites do laboratório, tem mostrado ao mesmo tempo a inadequação de uma abordagem que tende a desprezar a dimensäo especificamente biológica do mal (Rosemberg, 1988:29).

Seguramente, a AIDS é apenas um dos elementos de uma nova conjuntura que está nos forçando a assumir outras posiçðes teórico-metodológicas. As (ultimamentc) um tanto belicosas relaçőes entre ciências sociais e biológicas começam também a assumir novas feiçoes. Chamo novamente a atenção para o programa do I Encontro. Nele, é bastante significativo o uso da conjunção e. Apcnas a sessão que trata de construçáo social diz "da doença". Năo temos uma Antropologia da AIDS. nem das doenças endêmicas, nem da saúde urbana ou da saúde mental. temos sempre Antropologia e ...

\section{VELHAS E NOVAS PISTAS}

Næo poderei aqui avançar muitas idćias no sentido das vias que se oferecem para a superaçăo de um dilema que é tão crucial quanto complexo, quasc um sinal distintivo desse final de milênio. Obviamente. como me parece estar sendo cada vez mais freqüente na prática, podemos retomar a paradigmas anteriores; voltar a considerar apenas, como dizia Heralich, o que acontece antes, em torno e depois de um fato medicamente definido. Podemos retomar a questão da multifatorialidade ou da complementariedade necessária das abordagens sociológica, psicológica, e fisiopatológica, como parce ser a saída proposta tanto por Rosemberg quanto por Herzlich.

Entretanto, parece ser mais instigante repensar o próprio "construcionismo" à luz da tradiça antropológica e sociológica da qual ele faz uma apropriaçăo bastante singular. Talvez ño se trate de devolver aos cienlistas e médicos o monopólio do discurso objetivo, mas compreender com mais justeza a sua atividade e a nossa. Tendo a concordar com Herzlich quando diz que o "construcionismo", na medida em que trata a medicina "como simples resposta simbólica ou como pura ideologia", nos impede de elucidar o seu funcionamento e a eficácia de sua prática. E aqui se apresentam dois problemas inter-relacionados que eu gostaria de levantar rápida e limitadamente, à guisa de conclusăo deste ensaio.

O primeiro deles se evidencia no próprio uso um tanto frouxo que Herzlich faz das expressōes "resposta simbólica" e "ideologia", no texto citado, e que me faz. pensar no modo pelo qual. um tanto insensivelmentc, os conceitos de signo e simbolo vêm sc tornando quase sinônimos, perdendo qualquer especificidade analítica. Uma das consequêencias dessa indistinção parece ser a confusão entre a análise de atividades eminentemente simbólicas, como a ciência ou a magia, e a análise lingüistica ou do discurso, no sentido vulgar do termo (lembremos que White trata a ciência exclusivamente como linguagem). Efetivamente, a relação entre o significante e o significado parece ser completamente arbitrária e convencional no signo. Nesse sentido, a teoria do signo poderia ser mesmo aproximada às idéias mais clássicas sobre as idcologias, as quais, do ponto de vista do conhecimento, 
manteriam com a realidade a que se referem uma relaçă negativa ou de inversăo. Entre a matcrialidade do significantc e seu significado não há qualquer relação necessária. A mesma emissão sonora pode adquirir sentidos completamente diferentes segundo os diferentes contextos lingüisticos em que ocorre.

Lembremos que, para Sausurre, năo scria essa entretanto a relação que uniria o simbolo à coisa ou à idéia que ele designa. Conforme diz, diferentemente do signo lingüístico, "o simbolo se caracteriza por nunca ser completamente arbitrário; næo está vazio, há um rudimento de vínculo natural entre o significante e o significado. $O$ simbolo da justiça a balança, não poderia ser substituido por outro objeto qualquer. um carro, por exemplo (Saussurc. 1967:131). Assim. a caracteristica distintiva do simbolo reside justamente no fato de estar a meio caminho entre as palavras e as coisas. E. nesse sentido, se voltarmos a Durkhcim (que Whitc coloca na base de seu "construcionismo") veremos que as represcntaçōcs colctivas ou as catcgorias de pensamento (dc cunho cientifico ou năo) só são uma realidade eninentemente simbólica justamente por nunca sercm completamente arbitrárias. Nas Formas elementares da vida religiosa, publicada em 1912. Durkhcim cnfatizava mais de uma vez o valor objelivo das idćias colctivas. São. como diz. "simbolos bem fundados" $\mathrm{c}$ "sc. enquanto conccitos construidos. neles entra o artificio, é um artificio que segue bem de perto a naturcza" (Durkheim. 1990[1912]:26). Para cle, a representação colctiva "ne saurait donc ćıre complèıement inadequatc à son object. Elle peut exprimer. sans doute. à aide de symboles imparfaits; mais les symbole scientifiques eux-même ne sont jamais qu'approchés" (Durkheim. 1990|1912]:625)

Para Durkhcim, as catcgorias colctivas são como "obras de arte" por "imitarem" "a natureza com uma perf́cição passivel de crescer sem limites". E são ainda parentes próximas dos "utensílios" (Durkhcim. 1990|1912] notas 2 e 3). É certo que, concebendo a socicdade como "natureza segunda". Durkhcim vê uma analogia fundamental entre o modo pclo qual homens e coisas se organizam. Dai a possibilidade de categorias engendradas socialmente serem ao mesmo tempo compativcis com o mundo natural. Mas o que eu gostaria de enfatizar aqui ć o fato de as comparações constantes que faz cntre as categorias e as obras de arte. os artefatos e utensilios, Icvar a crer que elc apontava justamente para este carátcr ambiguo, compósito e hibrido do simbolo. Não sc trata de concepçõcs construidas sobre as coisas. mas com as coisas. Não poderiam. como no caso do signo, serem completamente diferentes do que são. Fenômenos. ncm totalmente sociais. ncm totalmente naturais. Quase-idćias. ou tomando emiprestado do vocabulário de Bruno Latour. "quase-coisas" (Latour. 1991). cuja análise só parece scr possivel se nos desvencilharmos da idéia de que natureza/cultura são dimensões diferenciáveis $\mathrm{e}$ opostas da realidade.

$O$ "construcionismo" de Whitc diz que a ciência atua no sentido de transformar "statments of values into apparent statements of fact". Uma atividade que parece se passar integralmente no rcino da linguagem. pois são sempre "statments of". E é ncsse nivel que a oposição natureza/cultura pode ser mais facilmente supcrada através da eliminação de um de seus pólos. É certo que a atividade discursiva é uma parte importante da alividade cientifica, mas uma outra nåo menos considerável consiste $\mathrm{cm}$ transformar coisas em idéias e valores (e vice-versa), misturá-las. Misturas que os cientistas mobilizam nas suas lutas interminávcis. Se, como diz Foucault, o saber ć fcito para cortar e não para compreender (Foucault, 1979:28), acho bastante plausivel que o fio dessa lâmina dependa em grande 
medida do modo e da dimensåo em que, a partir da compreensto das coisas, ele as mobiliza de mancira eficiente. $\mathbf{O}$ que os cicntistas fazem em seus laboratórios (o que nós mesmo fazemos) nìo é certamente, como quer o cientismo vulgar, descobrir fenômenos que desde sempre estavam lá à sua espera. Eles constroem símbolos a partir de certos materiais. E a relação entre os simbolos e a realidade que buscam exprimir năo é nem totalmente aleatória, nem totalmente arbitrária. A queståo certamente ño é saber se o "vinus" existe lá antes de qualquer olhar curioso, mas se, a partir do momento em que ele se tranforma em símbolo da doença com a qual cle foi construído, ele tem poder explicativo e é eficiente para orientar uma intervençăo eficaz. Ele é um artefato biológico, foi feito pelos cientistas como todos os outros artefatos humanos, da roda ao computador.

E aqui tocamos no segundo problema: o fato de o simbolo ter sido despido de sua incômoda materialidade parcce ter feito com que a dimensăo propriamente técnica da atividade cientílica tivesse sido um tanto desprezada por nossa disciplina. E tal desdobramento de modo algum poderia ser previsto do ponto de vista da formulaçőes iniciais da Escola Sociológica Francesa. Um aspecto importante do clássico ensaio que Hubert e Mauss escreveram sobre a magia no comcço deste sćculo, cstá justamente na valorização da dimensão técnica e cognitiva da atividade mágica, compreendida como "arte prática", uma "arte de fazer", situada a meio caminho da ciência c da religiæo. Conforme dizem: "ela nāo é apenas uma arte prática: é tambćm um tesouro de idéias. Dá cxtrema importância ao conhecimento e este é uma de suas molas principais; vimos de fato, e por diversas vezes, que. para a magia. saber ć poder. Mas. enquanto a religião. por seus elementos intelectuais, tende à metafísica, a magia, que nós pintamos mais interessada no concreto. dedica-se a conhecer a natureza" (Mauss \& Hubert. 1974:171).

Bem mais tarde. já em 1927, ao tratar da organização das diferentes especialidades socioantropológicas. Mauss voltaria a ressaltar que, de scu ponto de vista, "o complexo ciência-técnica é um bloco." E apontava para a "natureza" sui generis da técnica, através da qual a axiomática divisão entre natureza e cultura é abolida. Scgundo cle, "as técnicas são, portanto, como todos os fenômenos sociais, arbitrárias, particulares à comunidade que as gera.. Mas, ao mesmo tempo. mais do que qualquer outro fenômeno social. as técnicas estâo aptas a ultrapassar os limites das sociedades... Em toda a parte säo a coisa social expansiva por excclência... E cis o por quê. A Rcligiăo, o Dircito, a Economia. såo limitados a cada sociedade, um pouco mais ou um pouco menos que a linguagem. mas como ela. Mesmo quando se propagam. ño passam de meios para a comunidade agir sobre si. Ao conurário, as técnicas, por seu tumo, são o mcio, desta vez material, de que uma sociedade dispoe para agir sobre o scu meio. Por clas, o homem torna-se sempre mais scnhor do solo e de scus produtos. Săo, pois, um compromisso entre a natureza e a humanidade" (Mauss, 1981:50-51, grifo meu).

Para Mauss, possuindo uma "posição extraordinária, extra-social", a técnica tem "uma natureza geral e humana". Como alertava aqui também, como no Direito e na Religiäo, o homem é "duplex", porém, continua "no êxtase religioso e no sacrificio moral, o homem e a sociedade permanecem cles mesmos com seus limites e suas taras. Na arte prática, o homem faz recuar estes limites, progride na natureza, a mesmo tempo que acima de sua própria natureza, porque a ajusta à naturcza. Identifica-se com a ordem mecânica, física, química das coisas. Cria e. ao mesno tempo, cria-se a si próprio; cria ao mesmo 
tempo seus meios de viver, coisas puramente humanas, e seu pensamento inscrito nestas coisas" (Mauss. 1981[1927] ).

Ora, colocar portanto Durkheim e Mauss na origem do "construcionismo", conforme apresentado por White, parece assim simplificador e abusivo. Poderiamos dizer que, no âmbito da Escola Sociológica Francesa, cuja tradição nesse sentido scria desenvolvida por Lévi-Strauss, uma compreensão sociológica da ciência não deriva apenas da análise do modo como as categorias de pensamento derivam da sociedade, sendo portanto arbitrárias, mas também da mancira como tais categorias se engajam nas coisas $\mathrm{e}$ as mobilizam atravćs das técnicas. Se as técnicas são ou não universais, um "tesouro da comunidade humana c não mais de tal ou qual socicdade" (Mauss, 1981 [1927]:52). como estabclecia o humanismo maussiano. me parece agora uma questão sccundária. $\mathrm{O}$ mais importante é. antcs de mais nada, reconhecermos sua "natureza" híbrida e compósita. Reconhecermos que Latour parece ter razão quando diz não ser mais possivel tratar a ciência como discurso ou como idcologia. uma vez que os cientistas não vivem num mundo de idćias. cles vivem num universo de coisas, e de coisas muito animadas $\mathrm{em}$ sua aparente e dócil imobilidade. 


\section{REFERÊNCIAS BIBLIOGRÁFICAS}

DURKHEIM, E. (1990) (1912). Les formes elémentaires de la vie religieuse. Paris: P.U.F.

EHRENREICH, J. (1978). "Introduction", in EHRENREICH (Org.). "The cultural crises of modern Medicine. New York: Monthly Review Press.

EVANS-PRITCHARD, E. E. (1978) (1937). Bruxaria, Ord́culas e Magia entre os Azande. Rio de Janeiro: Zahar Ed.

FOUCAULT (1937). Microfisica do poder. Rio de Janeiro, Graal Ed.

HERZLICH, C. (1984). "Médecine moderne a quâte de sens: la maladie significant social", in HERZLICH \& AUGÉ (Org.), Le sens du mal - Anthropologie. Histoire et Sociology de la Maladie. Paris, Ed. des Archives Contemporaines.

LATOUR, B. (1991). Nous n'avons jamais ĺés modernes - essai d'Anthropologie Symétrique. Paris, La Découverte Ed.

LEVI-STRAUSS, C. (1976). O pensamento selvagem. São Paulo, Ed. Comp. Nac.

MAUSS, M. \& HUBERT, H. (1974) (1901-1902). "Esboço de uma teoria geral da magia", in Sociologia e Antropologia, vol. 1. São Paulo. Edusp Ed.

MAUSS, M. (1981) (1927). "Divisões e Proporçōes das divisōes da Sociologia", in Ensaios de Sociologia. São Paulo, Ed. Perspectiva.

ROSEMBERG, C. E. (1988). "Disease and social order in America: perceptions and expectations", in AIDS: The burdens of history. Berkeley. University of Califomia Press.

SAUSSURE, F. (1976) (1945). Curso de Lingutstica general. B. Aires, Ed. Lousada.

WHITE, K. (1991) "The Sociology of health and illness". Current Socciology, vol. 39, n' 2, outono. 



\title{
3
}

\section{$\overline{\text { RELIGIÃO, RITUAL E CURA }}{ }^{*}$}

\author{
Miriam Cristina M. Rabelo
}

\section{INTRODUÇÃO}

A importância dos cultos religiosos na interpretação e tratamento da doença tem sido amplamente reconhecida na literatura antropológica. Mais do que isso, os antropólogos têm frisado peculiaridades e aspectos positivos do tratamento religioso quando comparado aos serviços oferecidos pela medicina oficial. Ao invés das explicações reducionistas da medicina, os sistemas religiosos de cura oferecem uma explicaçāo à doença que a insere no contexto sociocultural mais amplo do sofredor (Comaroff, 1980, 1985). Mais do que atribuir uma causa objetiva a estados confusos e desordenados, a interpretação religiosa organiza tais estados em um todo coerente (Lévi-Strauss, 1967). Enquanto o tratamento médico despersonaliza o doente (Taussig, 1980), o tratamento religioso visa agir sobre o indivíduo como um todo, reinserindo-lhe como sujeito, em um novo contexto de relacionamentos.

Assim, como vários estudiosos têm ressaltado, a passagem da doença à saúde pode vir a corresponder a uma reorientação mais completa do comportamento do doente, na medida em que transforma a perspectiva pela qual este percebe seu mundo e relaciona-se com outros. Fundamental nessa abordagem é identificar os meios pelos quais as terapias religiosas efetuam tal transformação. Neste sentido, nāo é à toa que tantos estudos têm se voltado para uma compreensão do ritual enquanto espaço por excelência, em que os doentes são conduzidos a uma reorganização da sua experiência no mundo.

Os estudos sobre ritual têm contribuído significativamente para uma compreensão da especificidade do tratamento religioso. Neste capítulo, reviso duas destas contribuiçōes mais recentes, procurando mostrar em que medida podem esclarecer importantes aspectos dos serviços religiosos de cura oferecidos no contexto brasileiro. Argumento, entretanto, que ao centrar exclusivamente a análise dos tratamentos religiosos no contexto do culto e, mais especificamente, do ritual, questões significativas relacionadas à utilização desses serviços são deixadas de lado. Concluo o capítulo apontando para algumas linhas complementares de análise.

* Trabalho apresentado no I Encontro Nacional de Antropologia Médica, Salvador (BA), três a seis de novembro, 1993. 


\section{O RITUAL ENQUANTO PRÁTICA TRANSFORMATIVA}

Ao se voltar para um estudo do ritual, vários antropólogos têm enfatizado seu papel transformativo: manipulando símbolos em um contexto extracotidiano, carregado de emoção, o ritual induz seus participantes a perceberem de forma nova o universo circundante e sua posição particular nesse universo (Geertz, 1973; Turner, 1967; Tambiah, 1979; Kapferer, 1979). Geertz (1973) explorou essa idéia ao sugerir que a briga de galos balinesa organiza experiências e sensaçōes do cotidiano dos balineses em um "todo" ordenado, constituindo para estes uma espécie de "educação sentimental". Partindo de um ponto de vista semelhante, Turner $(1967,1969,1974,1975)$ escreveu extensamente sobre como os rituais operam de modo a conduzir os indivíduos a determinados estados e atitudes frente ao mundo: o isolamento de objetos e imagens de seu contexto ordinário e sua recombinação em novos contextos, a focalização em determinadas unidades simbólicas, a combinação de fortes estímulos sensoriais e intelectuais.

De fundamental importância nessa perspectiva de análise do ritual é identificar e compreender os processos específicos através dos quais o ritual produz uma transformação da experiência de seus participantes. Em sua discussão sobre o papel das metáforas na cultura, James Fernandez oferece pistas interessantes nesse sentido. Fernandez (1986) define metáfora como uma predicação estratégica sobre um pronome incoato que faz um movimento e conduz à performance. As metáforas estendem a experiência informe do sujeito a domínios mais concretos e reconhecíveis. Através da atribuição de predicações metafóricas sobre si mesmos e os outros, os indivíduos procuram se situar mais favoravelmente em um determinado contexto relacional.

Segundo Fernandez $(1977,1986)$, os rituais pōem em açāo determinadas predicações metafóricas sobre sujeitos que necessitam de movimento. Estabelecendo um elo entre diferentes domínios, as metáforas provêem imagens em relação às quais pode se dar uma reorganização do comportamento. A encenação de metáforas em um contexto ritual, através do discurso, do canto e/ou da dança, constrói uma forte analogia entre o domínio encenado e o domínio da experiência cotidiana dos participantes, de modo que a ordem das coisas neste último passa a ser percebida como semelhante à ordem das coisas no primeiro. Como resultado, os indivíduos são irresistivelmente conduzidos a organizar seu mundo - e sua prática - de acordo com os novos cenários assim construídos.

Fernandez parte de analogia entre cultura e texto, teorizando sobre as estratégias textuais através das quais o ritual é capaz de (re)orientar a atitude dos seus participantes. Buscando compreender como tal efeito "transformativo" de fato se produz nos indivíduos, Kapferer (1979a) argumenta que analisar ritual é antes de mais nada examinar como significados, símbolos e metáforas são manipulados em um contexto de ação, i. e., por pessoas situadas diferencialmente em um espaço físico concreto e fazendo uso (ou sendo expostas) a diferentes meios de comunicação. "O ritual deriva sua eficácia e poder de sua performance e é na performance que o trabalho de transformação se realiza" (1979a:6).

Para Kapferer (1979), dois elementos chaves da performance devem ser levados em conta no estudo dos rituais. O primeiro diz respeito ao arranjo do espaço e organização dos participantes e audiência no local da performance. Durante a performance de um ritual os indivíduos podem passar de uma situação de meros espectadores a participantes diretos 
do drama encenado, respondendo diferencialmente aos vários estímulos visuais, auditivos e olfativos que lhes são lançados. "O movimento daqueles reunidos em uma ocasião ritual, através dos papéis de participante e audiência, é importante para um entendimento de como o ritual promove experiência e potencial para os indivíduos refletirem sobre essa experiência" (1979a:8). Totalmente envolvidos na ação, enquanto participantes, os indivíduos podem objetificar sua experiência para si e para os outros. À medida que a performance os distancia do quadro da ação, tornando-os audiência para ação, permite sua reflexão sobre essa mesma experiência.

Outro elemento importante na análise do ritual enquanto performance diz respeito ao uso dos meios - canto, dança, discurso formal, comédia, etc - através dos quais a ação é desenvolvida. A utilização de determinados meios durante a performance facilita a construção de certos cenários, contribuindo para persuadir os indivíduos a reorientarem sua ação em função dos novos contextos construídos.

Voltemos à questão da cura no contexto religioso e, mais especificamente, no contexto ritual. Kapferer (1979b) argumenta que o ritual produz cura na medida em que permite uma mudança na perspectiva subjetiva pela qual o paciente e comunidade percebem o contexto da aflição. Segundo Csordas (1983), a cura religiosa pode ser entendida como dinâmica de persuasão que envolve a construção de um novo mundo fenomenológico para o doente. No ritual de cura o doente é persuadido a redirecionar sua atençāo a novos aspectos de sua experiência ou a perceber esta experiência segundo nova ótica. A cura consistiria, assim, não no retorno ao estado inicial, anterior à doença, mas na inserção do doente em um novo contexto de experiência. Fernandez e Kapferer sem dúvida contribuem significativamente para o entendimento das estratégias rituais mediante as quais tal inserção é lograda.

\section{RITUAL E CURA NO CONTEXTO BRASILEIRO}

No Brasil há uma pluralidade de cultos religiosos que oferecem serviços de cura. Cada qual conta com um rico repertório de imagens e símbolos que expressam distintas visões de mundo e oferecem aos seus participantes posições e/ou papéis específicos neste mundo. Cada qual visa, através de seus rituais, reconstituir a experiência dos indivíduos de modo a conformá-la a estes papéis. A cura que prometem a seus clientes e seguidores $\epsilon$, via de regra, parte deste projeto mais abrangente. Aqui proponho analisar os projetos de cura e práticas rituais de alguns destes cultos à luz das contribuições discutidas acima.

Começo pelo jarê, uma variante de candomblé de caboclo, encontrada na Chapada Diamantina, região setentrional da Bahia. Nas zonas de agricultura da Chapada Diamantina o jarê constitui um culto de pequenos lavradores voltado, em grande medida, para a interpretação e tratamento da aflição (Rabelo, 1990). No jarê, tais atividades são realizadas pelos caboclos, entidades que os participantes do culto associam genericamente aos índios e que vêem como espíritos selvagens, poderosos e matreiros.

É possuído por um dos seus caboclos que o curador procede à revista, encontro com o cliente no qual deve reconstituir a cadeia de eventos que levaram este último à aflição. 
$\mathrm{Na}$ revista, o curador procura organizar fatos e sentimentos em uma narrativa coerente e ordenada que evidencie causas e aponte na direçāo do tratamento e da cura. Neste sentido, o trabalho (ritual de cura) representa a resoluçāo pública de uma história construída no contexto privado da revista.

O trabalho constitui, de fato, uma etapa bem delimitada do ritual do jarê. É apenas depois de celebrada a descida de toda uma série de caboclos - que vêm de Aruanda para vadiar no terreiro, apossando-se temporariamente do curador e dos seus filhos de santo que se iniciam as atividades de cura propriamente ditas. Não raro, o curador tem que fazer um esforço para interromper a brincadeira dos caboclos e conduzir o ritual em direção ao trabalho.

Durante o trabalho se produz uma reordenação do espaço e ação ritual: se por um lado todos permanecem em círculo, já não há mais dança ou possessão entre os participantes; apenas o curador permanece incorporado por seu caboclo, assumindo controle sobre a ação que se desenrola. Também ele já não dança; conduz cantos e rezas que formula mais ou menos livremente. Os demais presentes assumem uma posiçāo de observadores, chamados a contribuir com os cânticos introduzidos pelo curador; não raro decresce seu envolvimento no ritual. Os doentes e, por vezes, alguns de seus familiares, são colocados no interior de um círculo de pólvora traçado pelo curador, só então tornando-se o foco da atenção. Vestidos de branco, já foram banhados nos fundos da casa em banhos de ervas.

O trabalho se inicia com cantos a Exu, para que conceda sua licença à atividade de cura e comprometa-se a guardar as encruzilhadas, porteiras e cancelas que conduzem ao terreiro. Mais tarde, oferendas são feitas a Exu e depositadas em sua casa nos fundos do terreiro. $O$ tema da expulsão de agentes causadores da doença ganha expressão durante a performance que se segue: o curador introduz uma série de cânticos em que nomeia distintos poderes responsáveis pela doença (exus, sombras de morto), chamando-os a deixar o corpo do doente. Mudanças no comportamento do doente durante este processo atraem grandemente a atenção da audiência na medida em que confirmam a realidade construída pelo curador. Um novelo de lã é desfeito, simbolizando o desfazer do feitiço. Três panos de cor preta, vermelha e branca são esfregados, em seqüência, no corpo do doente, representando graus crescentes de purificação. Ao final do trabalho, o círculo de pólvora é queimado e os restos são varridos para fora da casa. Delimita, durante o ritual, um campo onde forças perigosas circulam antes de serem definitivamente expulsas do corpo, constituindo uma arena de mediação que deve ser dissolvida na conclusão do trabalho.

Entretanto, o curador não cura simplesmente forçando o mal para fora. Busca reconstituir o corpo, fortalecendo suas extremidades e fronteiras enfraquecidas e encerrando-o gradualmente em um círculo de proteção. Durante o trabalho, o curador permanece no interior do círculo, junto ao doente, concentrando a açāo sobre seu corpo. Envolve-o em cantos, admoestações e perfume, balançando uma lata de incenso em sua volta. Executa operação semelhante com a corda de São Francisco, que movimenta para cima e para baixo, na frente e nas costas do doente, desenhando com ela a silhueta do corpo e tocando-a nos braços estendidos, mãos, pés e cabeça. Tais gestos se repetem durante longo tempo, em meio a rezas e cantos, construindo uma imagem de gradual restauração da integridade do corpo, ameaçada pela doença. 
Ao final do trabalho, quando o círculo de pólvora é desfeito e os restos varridos porta afora, soltam-se fogos e reinicia-se a festa dos caboclos, que se prolonga até o amanhecer. Os doentes são conduzidos à camarinha, onde permanecerão por um período de mais ou menos sete dias sob os cuidados do curador. É o início do resguardo, durante o qual devem ser evitados alimentos e práticas que têm o efeito de "abrir o corpo" e, portanto, de desfazer o trabalho do curador. Embora a maioria das restrições seja suspensa com o tempo, algumas devem ser seguidas para sempre.

As metáforas corpo aberto versus corpo fechado, de fato, ordenam as concepções de saúde, doença e cura no jarê. Na visão do jarê o indivíduo está continuamente interagindo com pessoas, espíritos e coisas que não pode controlar e dos quais sabe muito pouco. $\mathrm{O}$ mundo é uma realidade fragmentada em relações cambiantes que invariavelmente produzem aflição; falta-lhe uma ordem abrangente. Fruto de relacionamentos, a doença se produz em uma situação de vulnerabilidade (corpo aberto) do indivíduo frente ao meio. A cura busca redefinir o contexto relacional gerador da doença, agindo sobre um dos participantes da relação. Consiste fundamentalmente em uma tentativa de fortalecer o indivíduo, fechando seu corpo, de modo que ele esteja emi uma posição mais vantajosa ou menos vulnerável para relacionar-se com outros e, assim, realizar seus objetivos no mundo.

Essa idéia ganha força através da performance e da forma específica pela qual esta constrói determinados cenários, movendo os indivíduos no espaço ritual e segundo distintos papéis. Primeiro é preciso observar que é de sua inserção no quadro mais abrangente da festa dos caboclos que o trabalho deriva sua força e realismo para clientes e audiência: a cura se efetiva em um campo de poder previamente construído pelo drama da entrada dos espíritos nos corpos dos participantes. Tal cenário, entretanto, longe de obedecer a uma ordem a priori, revela-se plural e repleto de incertezas: os caboclos tanto podem curar a doença como causá-la.

Inserida em tal contexto a cura só se efetiva se o curador souber lidar com os caboclos e desta maneira suceder em drenar seu poder ambíguo para a realização dos fins privados do seu cliente. A substituição da dança pelo canto e discurso enquanto modos de comunicação marca um movimento em direção ao controle da ação pelo curador. A transformação definitiva dos participantes em audiência durante o trabalho produz uma redefinição do contexto que também aponta nessa direção. Parece, além disso, expressar a idéia de que enquanto a festa dos caboclos é atividade coletiva, desprovida de fim aparente (que não o próprio desejo de vadiar dos caboclos), o trabalho é atividade explicitamente voltada para a realização de fins privados. Assim é que ao envolvimento marcado dos participantes na celebração dos caboclos sucede-se um certo alheamento durante o trabalho.

Ao redefinir o foco da ação para a atividade de cura, o curador busca dar uma direção unificada a um drama que até então se desenrolara enquanto desfile de múltiplas personagens e vontades no espaço ritual. Entretanto, se para curar deve controlar o fluxo de poder no campo ritual, tal controle exige necessariamente negociação. É preciso primeiro deixar que os caboclos se satisfaçam dançando no terreiro. É preciso também pedir licença a Exu, garantindo através de oferendas sua cooperação na guarda dos limites e entradas do terreiro. A performance do trabalho permite ao doente redefinir a perspectiva subjetiva sob a qual avalia sua posição em determinado contexto relacional: de um estado de fragilidade para 
um de força e proteção renovadas. Com ela o doente aprende a necessidade de contínuas alianças pessoais para garantir uma posição menos vulnerável no mundo.

Bastante distintas são as concep̧̧ões de doença e cura encenadas no rito pentecostal. É a elas que agora remeto. Nas igrejas que praticam a cura divina. como a Igreja Universal do Reino de Deus, a sessão de cura constitui momento central do ritual, para o qual convergem todas as atençōes e expectativas. Muitas vezes, ao chegarem ao templo, as pessoas já encontram atividades de cura em andamento, sob a assistência das obreiras. Podem ser chamadas a colocar suas mãos sob uma mesa untada em óleo, para em meio a tantas outras mãos e aflições pessoais, se beneficiarem do poder purificador do óleo. Podem ser rezadas individualmente pelas obreiras, em cujos olhos atentos dificilmente escapa alguém sem ser atendido. É, entretanto, com a entrada do pastor que se inicia o culto e a cura divina propriamente dita.

No culto pentecostal a cura é encenada como uma batalha na qual o pastor, suas obreiras e os demais fiéis oram juntos para expulsar as entidades do mal que estão alojadas no corpo do doente. Muitas vezes o pastor chama doentes e aflitos à frente para que possa proceder à oração de cura, pedindo-lhes que coloquem a mão sob a parte enferma do corpo. Reza em tom de comando enquanto emissário do poder de Jesus Cristo sobre o mal. Colocando suas mãos sobre o local indicado pelo doente, ordena para que Satanás e seus comparsas manifestem-se e curvem-se perante o poder de Cristo. A mesma oração é proferida várias vezes, substituindo-se apenas o nome da entidade maléfica; na Igreja Universal, estas sāo vários exus (da feitiçaria, do vício, etc), quando nāo os próprios orixás. A voz ríspida e desafiadora do pastor gradativamente se mistura às vozes das obreiras, que repetem operaçōes semelhantes em outros doentes, $\mathrm{c}$ dos demais participantes, cada qual enunciando sua própria oraçāo. A atmosfera é tensa e parece caminhar para um clímax final. Em meio à profusão de vozes e orações pode-se distinguir, em intervalos variáveis, gritos de "Sai, sai, sai", que marcam o final de cada oração, quando o pastor e/ou obreiras retiram bruscamente a mão que vinham comprimindo sobre o doente. Tal movimento, marcando o cessar repentino de uma pressão sobre o corpo, reforça a imagem da cura enquanto expulsão de algo que comprime e pesa sobre o mesmo.

Mudanças no comportamento do doente durante o ritual - choro, tremor, perda de consciência, ataques - são esperadas enquanto sinais de que a entidade nomeada na oração finalmente se manifestou. Algumas vezes o pastor se envolve em diálogo direto com tais entidades manifestadas no doente procurando firmar sua autoridade e poder frente a elas. A presença das mãos sobre o doente transtornado caracteriza sua intervenção durante o processo.

A metáfora da luta permeia todo ritual: a cura marca a vitória do bem sobre o mal. Assim, ao invés de constituir-se exclusivamente em assunto privado - busca de melhoria pessoal neste mundo - faz parte do projeto coletivo do culto - construção de um subuniverso de ordem em meio ao caos circundante. Esse projeto está refletido na própria posição dos participantes durante o ritual: longe de desviar sua atenção do processo de cura, demonstram envolvimento acentuado na batalha que se trava contra Satanás, orando fervorosamente pela expulsão final das entidades maléficas do corpo do doente. A performance, de fato, constrói para seus participantes o papel de guerreiros auxiliares, co-responsáveis pelo desfecho da luta encenada ao redor do corpo do doente. A concen- 
tração da performance no discurso (oração) e o ritmo crescente em que este é proferido conduzem a representação de um conflito que caminha para uma pronta resolução. A mistura de vozes descompassadas cria um clima de tensão cujo caráter extraordinário aponta para a construção de uma arena especial onde o poder sagrado circula. Neste contexto o doente $\boldsymbol{\epsilon}$ totalmente envolvido na batalha que se trava ao redor do seu corpo, enquanto alvo imediato das palavras e gestos proferidos, não raro objetificando através de mudanças de comportamento o próprio desenrolar do drama.

A visão de mundo pentecostal se assenta em uma oposição rígida entre o bem e o mal; trata-se, em última instância, de planos descontínuos e irreconciliáveis (Brandão, 1980; Fernandes, 1982). A doença, enquanto sinal de desordem, é categoria pertencente ao segundo plano; interpretá-la é forçar a entidade causadora a se manifestar durante o ritual e, portanto, conformar a afliçāo pessoal ao modelo dicotômico do culto. Neste sentido, a dimensão interpretativa não constitui processo elaborado e nem tampouco requer um encontro privado entre doente e o pastor. Encenando uma batalha contra o mal, o ritual de cura divina visa conduzir o doente a perceber que foi efetivamente movido de um universo de caos e doença para um mundo ordenado, o único que pode garantir-lhe vitoria contínua contra a enfermidade. Ensina ao doente a necessidade de reorientar seu comportamento segundo as exigências morais deste novo mundo, firmando com ele um compromisso militante.

No quadro do ritual espírita há pouco espaço para metáforas guerreiras e para a encenação pública de batalhas contra o mal. No espiritismo, boa parte das enfermidades é fruto da ação de espíritos obsessores, entidades menos desenvolvidas que provocam a doença porque de fato ignoram a maneira correta de agir (Greenfield, 1992; Droogers, 1989; Warren, 1984). No ritual espírita, as entidades causadoras da doença são tratadas com gentileza, como se fossem crianças que precisam ser ensinadas a se comportar de maneira apropriada e motivadas a substituir a ação destrutiva, causadora da doença, por uma açāo construtiva e benéfica. Assim, ao curar o doente, os terapeutas espíritas estão também contribuindo para o progresso moral das entidades responsáveis pela doença. A metáfora da batalha que orienta a cura no culto pentecostal e que justifica a atitude agressiva do pastor frente aos espíritos é substituída pela imagem do ensinamento dedicado: a cura é essencialmente tarefa pedagógica pela qual espíritos menos desenvolvidos são conduzidos a estágios superiores de existência.

O ensinamento no espiritismo se dá em dois níveis principais. No primeiro, doentes e familiares se reúnem para ouvir as pregações do presidente do centro: livretos contendo os principais ensinamentos do culto são também distribuídos. No segundo nível, a ação é dirigida aos espíritos responsáveis pela doença. Em tais ocasiōes, o doente e seus acompanhantes são conduzidos a um encontro mais privado com médiuns do centro.

A sessão se inicia quando um dos médiuns é manifestado do espírito que se aloja no corpo do doente; então, passa a desenrolar-se um diálogo entre especialistas religiosos e o espírito, cujo conteúdo é claramente pedag 6 gico: o espírito deve ser persuadido a mudar de conduta, de modo a permitir que o doente em cujo corpo se aloja possa recuperar seu bem-estar. Neste sentido, diferentemente do pentecostalismo, onde o paciente é conduzido a vivenciar de maneira crítica a manifestação do outro em seu corpo, no espiritismo ele 
torna-se um espectador passivo de um diálogo entre seu duplo e o terapeuta. A performance distancia o doente da ação, potencializando sua capacidade de refletir sobre a ação.

A conversa informal constitui-se no modo de comunicação privilegiado para a construção do cenário da cura. A mudança gradual na atitude do espírito durante as sessões (que podem ser várias), de recusa aberta ao diálogo a uma crescente sensibilização às palavras do terapeuta, redefine o contexto da doença. Embora as exortaçōes dos médiuns sejam dirigidas ao espírito que visam instruir, o ritual busca através desse processo instruir o doente e membros do seu círculo de apoio a reorientarem seu comportamento de acordo com as mudanças que observam se verificar no cenário que constrói (i. e., na atitude dos espíritos em função da qual é definido tal cenário).

\section{CONSIDERAÇÕES FINAIS}

Os centros espíritas, as igrejas pentecostais e os terreiros de jarê constroem, na performance ritual, distintos projetos de cura. Estudar estes rituais -e os meios específicos pelos quais desmontam determinados cenários e criam outros - $\hat{e}$, em grande medida, poder compreender como diferentes modelos religiosos de cura são transformados em imagens e práticas que possibilitam uma ressignificaçāo da experiência do doente. Limitar a análise do tratamento e cura ao contexto do ritual, entretanto, traz alguns problemas para o entendimento do papel da religião na solução das doenças e aflições cotidianas de seus clientes.

Em grande medida isso se deve a limitações nos mesmos modelos utilizados para analisar o ritual. Em linhas gerais, estes se assentam sob duas suposições problemáticas. A primeira refere-se à idéia de que a cura consiste em um processo pelo qual o terapeuta confere ordem à experiência caótica do doente (i. e., transforma uma experiência que é insuportável para o doente, pois desprovida de sentido em uma experiência que the é aceitável e com a qual pode finalmente lidar porque reconstruída enquanto totalidade significativa). A segunda suposição, bastante ligada a esta primeira, diz respeito a uma visão do ritual enquanto campo homogêneo, i. e., onde os indivíduos compartilham e aceitam de forma não-diferenciada os significados apresentados pelo especialista de cura. Sob esta perspectiva, o culto e mais especificamente o ritual passam a ser tomados como campos fechados, que absorvem do meio social mais amplo indivíduos com experiências informes e incomunicáveis e que após organizar estas experiências, devolvem-nos, curados, ao meio.

Esta abordagem tem sido duramente criticada por Taussig (1992), para quem a experiência da desordem pode vir a ser o produto final da sucessão de imagens e gestos no ritual. A questão que gostaria de levantar aqui, entretanto, diz respeito menos aos cenários que o ritual apresenta aos seus participantes do que aquilo que estes trazem, expressam e negociam no contexto do ritual. A interpretaçăo que confere ao ritual função ordenadora por excelência pressupōe que os indivíduos ali ingressam desprovidos de modelos para comunicar e lidar com a aflição, sujeitando-se aos significados construídos através da performance. Entretanto, quão caótica é de fato a experiência do doente antes de entrar no 
culto e ser submetido ao ritual ? Até que ponto as metáforas utilizadas na interpretação do ritual não apresentam uma imagem por demais objetificada e passiva dos indivíduos "movidos" segundo dinâmica que parece ser inerente à própria performance?

Falar de cura como realidade construída social e culturalmente significa, em larga medida, explorar a perspectiva dos atores na análise do processo terapêutico, i. e., dar conta de práticas que envolvem planos, intenções e orientações mútuas. No que toca o estudo dos rituais de cura recuperar a perspectiva dos atores, não é apenas repensar o modelo de análise do ritual, mas de fato ampliar o foco do estudo para além do campo específico da performance e buscar a sua articulação com contextos mais abrangentes de relaçōes sociais. Sem que esta articulaçāo seja efetivamente explorada - i. e., enquanto a análise permanecer restrita aos símbolos e práticas rituais - dificilmente se poderá compreender o que garante o sucesso da ordenação imposta pelo ritual. Isso, porque o sucesso de um projeto de cura depende em larga medida da existência de redes de relações sociais que o sustentem enquanto discurso dotado de autoridade.

O tema da produção de significados - que orienta grande parte dos estudos sobre ritual - aparece, assim, indissoluvelmente ligado à questão da manutenção de significados, i. e., de discursos legitimados no curso de determinadas interações sociais, tanto ao interior do domínio do ritual como também fora dele. Esta questão é especialmente relevante no contexto popular urbano, onde uma ampla gama de serviços religiosos de cura é disponível e efetivamente utilizada pelos indivíduos durante um mesmo episódio de doença. Aí, longe de ser resultado direto de medidas rituais, a cura aparece como realidade, por vezes bastante frágil, que precisa ser continuamente confirmada no cotidiano do doente e membros do seu círculo de apoio.

Inquirir sobre os tratamentos religiosos é, assim, não apenas compreender a dinâmica interna do ritual, como também explorar o contexto mais amplo sobre o qual se desenvolve a experiência da doença e da cura. Por um lado, isso implica investigar os processos de interação (redes sociais) que sustentam determinadas interpretações, conferindo-lhes legitimidade. Por outro, implica analisar a relaçāo entre os símbolos e práticas rituais e o próprio curso da doença, visto aqui como realidade cultural e biológica. 


\section{REFERÊNCIAS BIBLIOGRÁFICAS}

BRANDÃO, C. R. (1980). Os Deuses do Povo. São Paulo, Brasiliense.

COMAROFF, J. (1980). "Healing and the Cultural Order: the case of the Barolong boo Ratshidi" American Ethnologist, 7(4): 637-57.

- . (1985). Body of Power, Spirit of Resistance. Chicago, Chicago University Press.

CSORDAS, T. (1983). "The Rhetoric of Transformation in Ritual Healing" Culture, Medicine and Psychiatry, 7: 333-375.

DROOGERS, A. (1989). "The Enigma of the Metaphor that Heals: Signification in an Urban Spiritist Healing Group" (mimeo). Annual Meeting of the American Anthropological Association, Washington D.C.

FERNANDES, R. C. (1982). Os Cavaleiros do Bom Jesus. São Paulo, Brasiliense.

FERNANDEZ, J. (1977). "The Performance of ritual Metaphors" in J. SAPIR \& J. CROCKER (Eds), The Social Use of Metaphor. Pennsylvania, The University of Pennsylvania Press.

- . (1986). Persuasions and Performances: the play of tropes in culture. Bloomington, Indiana University Press.

GEERTZ, C. (1978). A Interpretação das Culturas. Rio de Janeiro, Zahar.

GREENFIELD, S. M. (1992)."Spirits and Spiritist Therapy in Southern Brazil: A Case Study of an Innovative, Syncretic, Healing Group" Culture, Medicine and Psychiatry, 16(1): 23-52.

KAPFERER, B. (1979a). "Introduction: Ritual Process and the Transformation of Context", Social Analysis, 1:3-19.

— . (1979b). "Entertaining Demons" Social Analysis, 1: 108-152.

LÉVI-STRAUSS, C. (1967). Antropologia Estrutural. Rio de Janeiro, Tempo Brasileiro.

RABELO, M. (1990). Play and Struggle: Dimensions of the Religious Experience of Peasants in Nova Redençao, Bahia. Ph.D. Thesis, University of Liverpool.

TAMBIAH, S. (1979). "A Performative Approach to Ritual", Proceedings of the British Academy, LXV: 113-169.

TAUSSIG, M. (1980). "Reification and the Consciousness of the Patient", Social Science and Medicine, 14B: 3-13.

- . (1992). Xamanismo, Colonialismo e o Homem Selvagem. Paz e Terra.

TURNER, V. (1967). The Forest of Symbols. Ithaca, Cornell University Press.

- . (1969). The Ritual Process. Chicago, Aldine.

- . (1974). Dramas, Fields and Metaphors. Ithaca, Cornell University Press.

- . (1975). Revelation and Divination in Ndembu Ritual. Ithaca, Cornell University Press.

WARREN, D. (1984). "A Terapia Espírita no Rio de Janeiro por volta de 1900", Religiâo e Sociedade, 11(3). 


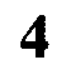

\title{
REPRESENTAÇÕES DA CURA NO CATOLICISMO POPULAR
}

\author{
maria Cecílla de SOUza Minayo
}

\section{INTRODUÇÃO}

Este artigo trata da representação social da cura no catolicismo popular. Resume o esforço de uma investigação realizada num centro de peregrinação denominado Porto das Caixas, no Estado do Rio de Janeiro, município de Itaboraí. A partir de autores clássicos da sociologia e antropologia religiosas, e da pesquisa empírica, o texto chega a algumas conclusões importantes para a área da Antropologia da Saúde. Porém, mais do que confrontar a definição oficial de cura com a que se gera no seio do catolicismo popular, pretende-se mostrar como, numa situação concreta, os fiéis se definem, definem sua relação com o sagrado e assim definem também sua cosmovisão presente nas práticas religiosas em relação à saúde $\mathrm{e}$ à doença.

\section{MATERIAL E MÉTODO}

Esta pesquisa se realiza em Porto das Caixas, no santuário de Nossa Senhora da Conceição, onde existe a imagem de Cristo Crucificado que, segundo versōes dos fiéis e da população local, teria vertido sangue e seria milagrosa.

A escolha de um centro de peregrinações para estudar a concepção de cura deve-se à importância indubitável de entrevistar as pessoas "em situação". Ou seja, quem busca a cura num santuário não se imagina frente a pequenos problemas que são resolvidos cotidianamente na luta da vida, com esforço pessoal ou pela colaboração de amigos, familiares ou companheiros. Quando uma pessoa em nossa sociedade move-se pela cura está frente a situações que considera situaçōes-limite, concretizadas em doenças graves, insegurança material e espiritual e desordens morais. A procura de saída de circunstâncias aflitivas soa então como recorrência a uma "tábua de salvação". 
Em seu livro, El Dosel Sagrado, Berger assinala que toda ordem sagrada é uma reafirmação contra o caos. Em sua ótica, o ser humano, através da religião, é levado a aceitar o sofrimento e até a morte. na medida em que isso possa ter um significado convincente para os momentos cruciais de sua vida. (Berger, 1966:44-71)

O fenômeno religioso cumpre assim o papel de facilitar às pessoas em situação-limite a compreensão do inexplicável e a aceitação do antes impensável. Essas reflexões estão presentes também em autores como Zaluar (1973:173-194; 1980:161-189); Wolf (1970:131-146); e Lévi-Strauss (1970:216).

Embora o núcleo de informantes tenha constado de 20 peregrinos presentes e em visita ao santuário, a pesquisa se iniciou na cidade do Rio de Janeiro. Começou com a abordagem de um casal que há mais de 15 anos organiza, mensalmente, romaria a Porto das Caixas, possuindo informaçōes preciosas sobre a história do acontecimento e um arquivo privilegiado sobre milagres, bênçãos e graças ocorridas no santuário. Esse arquivo constitui-se num documentário escrito, fundamental quando confrontado com os depoimentos dos devotos. Em seguida, também no Rio de Janeiro, foi entrevistada uma peregrina que há muito tempo freqüenta o santuário tomando o Cristo Crucificado de Porto das Caixas como parceiro e repositório das dificuldades, problemas e necessidades de sua família.

Em Porto das Caixas foram realizadas entrevistas abertas, distribuindo-se assim por estratos sociais: a) cinco pessoas de alto poder aquisitivo; b) seis pessoas de classe média e c) nove pessoas das camadas populares. Ao todo foram abordados 20 devotos, três no Rio de Janeiro e alguns moradores do local dos milagres, sobretudo comerciantes que trabalham nas imediações do santuário com venda de material religioso.

Dentre os devotos entrevistados, destaca-se a existência de uma profissional do jornal $O$ Dia, pessoa de alto padrão de vida, que, se sentindo miraculada pelo Cristo de Porto das Caixas de uma enfermidade considerada incurável pelos médicos, passou a dedicar seus serviços profissionais à divulgação da devoção. Há mais de 15 anos trabalha no local fazendo não só a cobertura jornalística mas atuando como verdadeira militante religiosa na propagação da crença ali praticada.

Das pessoas da localidade, sobretudo dos comerciantes de objetos religiosos, as informações foram escassas. Preferem silenciar sobre o que ouvem a respeito do recinto sagrado. Alguns, porém, confirmam que "às vezes as pessoas coxas saem andando, cegas saem vendo, e que tudo se dá pelo poder da fé".

Não foi possível conversar com nenhum padre que serve à igreja porque geralmente também se esquivam de falar sobre o tema. Na observaçăo feita no santuário, nos pátios $\mathrm{e}$ na visita minuciosa realizada à casa dos milagres, deduz-se que esses agentes religiosos vão a reboque de um movimento cujo ator principal é o povo, o povo nas suas agruras nãosuperadas no cotidiano rotineiro das práticas sociais. 


\section{O CENÁRIO E O MITO}

\section{"Eu sei que ali não está o santo, né? Quem é santo está lá em cima. Mas ali é um lugar de luz." (uma devota)}

Situado na região de Itaboraí, Estado do Rio, Porto das Caixas remonta ao século XVI (sesmaria doada aos jesuítas por Miguel de Moura, em 1571). A sua população vive da pequena agricultura, do trabalho assalariado do campo e de indústrias de cerâmica bruta. O lugarejo geograficamente se desenha como um semicírculo em torno da igreja de N.Sa. da Conceição, erigida pelos jesuítas em 1595. É no centro dessa capela, já remodelada várias vezes e que mantém ainda parte da arquitetura primitiva, que está a imagem de Cristo Crucificado, considerada milagrosa e capaz de congregar a seus pés milhares de peregrinos.

Segundo versão dos devotos, consignada também num folheto de divulgação chamado "Porto das Caixas-ano 10", exatamente no dia 26 de janeiro de 1968 essa imagem teria vertido sangue por suas chagas, ininterruptamente, por duas horas e meia. $O$ fenômeno, presenciado primeiro por um garoto pobre da localidade, filho do zelador da igreja, foi testemunhado a seguir pelo vigário e por vários fiéis. Conforme depoimentos, exames laboratoriais confirmaram que o sangue saído da imagem é humano, e o auto do fato se acha lavrado e registrado em cartório.

À ocorrência do fenômeno seguiram-se os milagres. Segundo os devotos, pessoas com doenças incuráveis e com toda uma gama de problemas recorrem ao Cristo de Porto das Caixas e recebem "cura ou alívio para suas afliçōes".

Evidentemente, o povoado pequeno e desconhecido, a partir dos acontecimentos que se deram em janeiro de 1968, tornou-se o cenário privilegiado de expressōes do catolicismo popular como Lourdes, Fátima ou Aparecida. A partir daí, milhares de devotos passaram a buscar, no local, os favores de Cristo Crucificado. Segundo informaçōes, a cidadezinha mal comporta a caravana dos peregrinos. Mesmo durante a semana a igreja e o lugarejo estāo repletos de fiéis.

Neste sentido, Porto das Caixas, a não ser pela extrema pobreza do povoado e pela precariedade de infra-estrutura para acolher a quantidade de pessoas que para lá acorre, não se diferencia dos lugares tradicionais de peregrinação: a igreja, a imagem milagrosa, a sala dos milagres, as lojas de objetos religiosos, o ambulatório para emergências, o precário refeitório para os fiéis. Fora do perímetro considerado sagrado, está um número incontrolável de barracas, onde se vendem desde a água para ser benzida, velas, imagens, postais, fitas, até quadros de outros santos de devoção popular e brinquedos de crianças.

Da multidão de peregrinos se destacam os devotos das camadas populares, muito embora se possa constatar a presença de pessoas de alto nível econômico $\mathrm{e}$ possuidoras de estudos de nível superior.

A narrativa popular do fato revela imediatamente dois aspectos importantes da religiosidade. $\mathrm{O}$ primeiro diz respeito ao conceito de lugar sagrado. $\mathrm{O}$ segundo refere-se à própria estrutura do acontecimento.

"Deus está em toda parte", afirma uma devota, "mas aqui o Cristo sangrou". O fenômeno ocorrido numa imagem visível, material, mostra a presença e a atuação de uma força sobrenatural. Para os devotos o lugar se torna então "lugar privilegiado da ação da graça de Deus", conforme um fiel, "ação maravilhosa dos poderes divinos", segundo outro; 
conseqüentemente, o lugar passa a ser identificado como espaço miraculoso. Se aconteceu, necessariamente pode acontecer outras vezes, parafraseando Mauss (1979), a crença num caso de milagre implica a crença de todos os casos possíveis. Ao contrário, uma negação pode fazer ruir todo o edifício.

A demanda de milagres acompanha, pois, a aparição do fenômeno. As pessoas começam a visitar o lugar e a considerá-lo "sagrado". Legitimado o fenômeno pela fé popular, não só a imagem, mas a igreja e a localidade são agora espaços santos e miraculosos. Os objetos benzidos na igreja ou que tocam a redoma da imagem milagrosa, assim como os ritos religiosos realizados no local, passam a ter privilégio frente aos mesmos objetos, ritos e coisas benzidos em outras igrejas: "eu poderia rezar em qualquer lugar, porque Deus está em toda parte, mas é aqui que eu recebi a graça, e por isso, aqui é que tenho de cumprir a promessa" (uma devota). O tema do sagrado é uma questão central da análise sociológica de Durkheim, que assim a resume:
"O que define o sagrado é o fato de ser acrescentado ao real"
(...) Neste espaço "as energias vitais estäo superexcitadas, as paixões mais vivas, as sensações mais fortes; existem mesmo algumas que só se produzem senão neste momento. O homem não se reconhece: sente-se como que transformado e por conseguinte, transforma o meio que o rodeia. Para explicar- se as impressões muito particulares que experimenta, ele atribui às coisas com as quais está em relação, poderes excepcionais, virtudes que não possuem os objetos da expe- riência vulgar" (Durkheim, 1978:226).

O segundo aspecto é que a explicação do fenômeno obedece à estrutura de eventos totalmente semelhantes, tais como as apariçōes de Lourdes, Fátima, Garabandal, Aparecida e Salete.

a) Em primeiro lugar aparece como a necessidade de reordenação da ordem social considerada cabtica:
"Pensou-se na área do fenômeno, que o Rio de Janeiro é um lugar de perdição, então o Cristo deveria para corrigir esse mal que existe na nossa sociedade, essa falta de equilíbrio social, de correção." (um devoto).

b) Em segundo lugar, a manifestaçāo da divindade se faz num lugar pobre, desconhecido: "M. S.: o Rio de Janeiro é uma cidade de riqueza e luxo. Então Cristo procurou um lugar pobre, como ele sempre fez durante sua vida. Porto das Caixas é um lugar paupérrimo. Aquele local serviria de ambiente para o milagre" (um devoto).

c) Por fim, o fenômeno é presenciado por uma criança muito pobre, inocente, isenta das maldades do mundo:

"Quem viu o Cristo sangrar primeiro foi uma criança, ofilho do zelador da igreja. Ele chamou o padre e outras pessoas foram juntando e todos viram." 
Cria-se assim um "mito", uma narrativa de origem. O mito em todas as culturas 6 cosmogônico, tendo o homem como ponto de interseção entre o estado primordial da realidade e sua transformação. Ele não se opōe à realidade, expressa-a através do ritual que constitui verdadeira repetição do evento primordial que se incorpora nos costumes, instituições e técnicas tradicionais da coletividade. Segundo Lévi-Strauss, o mito resolve os conflitos de uma dada sociedade em nível da ideologia (Lévi-Strauss, 1970:183-254). É de se notar que os dois informantes dos detalhes sobre a aparição de Cristo são de classe abastada e vivem privilegiadamente no Rio de Janeiro, enquanto o lugar e o "herói"do fato são pobres, desconhecidos, do interior. A negação da ordem social vigente e a anunciação em termos de promessa de mudança retomam o passado "como Cristo fez durante sua vida" e buscam um ambiente de "milagre, onde a partir de então o mal se transforma em bem, onde o sofrimento se transforma em paz e em felicidade" (depoimento de um informante).

\section{OS DEVOTOS CATÓLICOS}

\section{"Eu alcancei. Foi minha fé. Deus que me ajudou."}

Tal afirmação formulada por uma peregrina é bastante típica das pessoas que aqui se denominam "devotos". Essa expressão se refere aos que atribuem poderes sobrenaturais, capazes de alterar a ordem natural das coisas, a lugares, objetos, pessoas, símbolos e ritos considerados sagrados e, portanto, realizam práticas devocionais capazes de atrair esses poderes para si e para seu grupo social.

O termo "católico" tal qual se usa neste trabalho diz respeito mais a uma condição sociocultural-religiosa pelo qual o sujeito é introduzido nos ritos sacramentais da igreja católica, basicamente o batismo, e tem uma série de práticas de devoção ligadas aos santos da mesma instituição, entre as quais, uma prática esporádica de participação na liturgia oficial. Incluem-se excepcionalmente as pessoas que assiduamente freqüentam os ritos litúrgicos oficiais.

No que se refere a Porto das Caixas, houve oportunidade e foi proposital a realização de entrevistas com pessoas de diferentes estratos sociais. Esse fato leva a constatar que não se trata de um fenômeno monopólico das classes populares. Em situaçōes-limite de desespero frente ao sofrimento, à dor, à morte, em nossa sociedade se recorre a poderes sobrenaturais, em vista da precariedade dos elementos naturais disponíveis, e nessa situação as classes se confundem (Berger, 1967). No entanto, aproveitando a expressão de Bourdieu sobre os "efeitos da compreensão dupla", diferentes são as posições de classe frente ao fenômeno. A pretensa e aparente unidade de que se reveste a religião na interpretação da ordem social apenas esconde as divisões e lutas que existem numa ordem social onde há distinções de classes, de status e de poder (Bourdieu, 1974:531).

Observa-se, neste caso, que o discurso dos devotos de alto poder aquisitivo vem marcado pela tentativa de encontrar explicaçōes, significados e teorizar sobre suas situações: "A gente não deve pedir um milagre, porque Deus é quem sabe o que é melhor"; "A gente vem antes de tudo para pedir um conforto espiritual"; "A gente vem pedir para 
mudar a nossa maneira de ver as coisas, a aceitação da vontade de Deus"; "Como $40 \%$ dos males são psíquicos, temos que buscar a cura desses males"; "encontrar a força da fé"; "pega na mão de Deus e vai"; "temos que pedir paciência" (Vários devotos de maior poder aquisitivo).

Há essa procupação espiritual explícita dos devotos das camadas populares, porém, seu discurso aponta de forma veemente uma angústia em relação a problemas prementes: "eu venho aqui porque meu marido está botando muito sangue pelo nariz, o médico está dando muita vitamina, mas ele está quase morrendo". "O médico disse que ele tinha de fazer uma operação no olho, mas eu não tinha condição. Eu vim, pedi a Cristo Crucificado e ele está curado" (devotos de classes populares).

$O$ fato de as classes populares explicitarem por fatos os seus problemas parece confirmar a tese de Bourdieu, segundo a qual:

"Para alguns, a resignação é a primeira liçäo da existência, enquanto para outros, ela deve ser conquistada laboriosamente, vencendo-se a revolta diante das formas universais do inevitável."(1974:54).

O posicionamento dos fiéis católicos frente ao fenômeno de Porto das Caixas, acima de tudo, revela uma concepção de vida e de mundo que reproduz, sob forma "transfigurada e portanto irreconhecível", as estruturas das relações socioeconômicas vigentes na sociedade.

Trata-se de uma visão cosmológica, onde o mundo aparece regido por um ser supremo que domina o bem e o mal e que controla individualmente as pessoas, premiando o bem e castigando o mal. O que se passa na Terra é sua vontade, cabendo aos seres humanos descobri-la, pois ela rege o destino de cada um. Há expressões reveladoras com referência ao problema das doenças e dos sofrimentos em geral: "vontade de Deus"; "provação de Deus", "destino de cada um", "a sociedade é que se volta contra o que é de Deus, pelas facilidades que dá aos homens"; "as doenças são provações de Deus para a gente se voltar para ele".

Nesse sentido, as doenças e os males em geral passam inclusive a ser interpretados com "bençãos-meios", reordenadores do universo pessoal ou social em situação caótica. $\mathrm{Na}$ mesma linha de pensamento, a busca de milagres se pode considerar uma tentativa de mudar a vontade divina, o que aliás, ideologicamente, se expressa de forma ambígua. Pois, ao mesmo tempo que Deus é o dono e governa o mundo, o indivíduo recebe o sofrimento por culpa sua, porque se esquece da divindade. Para mudar a vontade divina, ele deve assumir seu mal, sua culpa e regenerar seu comportamento individual.

Essa cosmovisão reforça e reafirma a ordem estabelecida, como já analisado por clássicos como Marx, 1972; Weber, 1971; Durkheim, 1978. Segundo o pensamento de Durkheim, a visão religiosa é a própria substancialização da organização social, sendo o culto a Deus não mais do que um culto disfarçado às sociedades de que o indivíduo depende (Durkheim, 1978)

Partindo de uma concepção verticalista e hierárquica, essa concepção leva as pessoas a buscarem saídas individuais para situações que fogem ao controle do indivíduo. Em termos "profanos", o ser humano viveria à mercê de sorte e azar. Em linguagem 
religiosa, a situação se traduziria em "graças", "provação" ou "castigo" de Deus. A busca de soluçōes para situações anômicas, como explica Berger, conduz à tentativa de manipulação do sobrenatural para se conseguir dons e favores, como se usa fazer com os poderosos do mundo (Berger, 1969:68). Tentando classificar as situações descritas pelos devotos, diríamos que buscam milagres frente a doenças consideradas incuráveis, situaçōes sociais de humilhação e desonra, busca de integração e prestígio na hierarquia social.

Por outro lado, a procura de milagres como fonte ordenadora das situações de insegurança e desespero reproduzem-se da mesma forma que na sociedade onde se dão as atitudes de clientelismo, em termos de conseguir privilégios que a aproximação aos ricos ou aos politicamente poderosos dá. Assim, Deus teria seus privilegiados. "Eu tenho uma amiga que ela está sempre lá, tudo o que ela pede alcança". "Tem qualquer probleminha na minha casa, eu me mando prá Porto das Caixas".

As falas dos devotos são, portanto, ordenadoras, porque, conforme lembra Durkheim "é sobre a vida moral que a prática e a fé religiosas têm a função de agir" (1978:224). $\mathrm{E}$ esse autor acrescenta que os atos rituais "não visam exercer um tipo de coação física sobre forças cegas e aliás, imaginárias, mas de atingir consciências, tonificá-las, discipliná-las" (1978:224). Para isso, a solução encontrada ultrapassa o mundo material.

"Nossos problemas estão se acumulando dia-a-dia, entāo as pessoas vêm aqui para fazer seus pedidos, para procurar através de Cristo uma paz particular, pessoal, né? Só Cristo mesmo pode resolver os problemas do mundo inteiro através de nossa fé."

Essa é a forma como outra devota, demonstrando seu entusiasmo por Porto das Caixas, apresenta a solução, para o que classifica a "fuga do caminho da verdade":

"Eu acho que as pessoas estāo com fome de Deus. E que bom seria se elas se voltassem para Deus. Acho que essa vida moderna, a facilidade que nós encontramos de tudo o que queremos nos perturbam e nos afastam do verdadeiro sentido da vida que é você casar, ter filhos, familia, você trabalhar. E Cristo nos faz voltar a isso."

Levando-se em conta que o primeiro depoimento é de um motorista e o segundo é de uma senhora de classe média alta, mais uma vez se intui aqui o duplo sentido da religião para os grupos sociais opostos, assim como a teorização religiosa dos devotos, revelando basicamente sua concepção de vida, sua posição social, seus problemas concretos, muito embora ambos os discursos sejam portadores de uma mensagem ordenadora. $O$ primeiro revela uma necessidade de mudança (embora a solução apresentada seja o Cristo), enquanto o segundo pede que se ordene o que parece dado eterno e imutável, porém está, no momento, incompreensível e caótico.

Além de aspectos da cosmovisão no catolicismo popular, o contato com Porto das Caixas levanta o problema da relação igreja oficial-devoção popular. Segundo Durkheim, "as superstições populares estão misturadas aos dogmas mais refinados." (Durkheim, 1973: 509). Também Bourdieu (1974:67), analisando a política das grandes religiões com as 
manifestações religiosas populares, nāo-eruditas, diz que a religião dominante acaba ritualizando as práticas religiosas e canonizando as crenças populares.

Pela observação e depoimento dos fiéis, percebe-se que a igreja exatamente não canoniza essas tais práticas, ela as acolhe mantendo-se em atitude de respeito, de prudência, de receio, fazendo tentativas de capitalizar o fenômeno para "evangelizá-lo". Cria-se, portanto, com respeito a isso, certa ambigüidade na relação igreja-devoto, como se pode constatar a seguir.

Antes de 1968 existia uma capela no lugarejo, a que a igreja hierárquica dava pouca atenção e presença apenas esporádica. Surge o fenômeno que foge à programação pastoral, que ali se resumia à administraçāo dos sacramentos e conservação das devoçōes locais. A saída imediata foi a tentativa de integrar o fato, de tal forma que ele fortalecesse a ordem religiosa estabelecida, a atuação de uma hierarquia sacerdotal. Depois do "milagre" modificou-se a atuação da igreja oficial. Foram colocados missionários no local. Passou-se a celebrar duas missas por dia durante a semana e quatro aos sábados e domingos. Tentou-se divulgar uma mensagem "evangelizadora", dentro da ideologia religiosa erudita e se desenvolveu uma série de práticas litúrgicas e paralitúrgicas para integrar os devotos dentro dos cânones estabelecidos.

No entanto, a lógica dos fiéis continuou a funcionar de forma diferente. Vão especificamente ao local em busca dos milagres e dos favores do Cristo Crucificado, para pedidos ou agradecimento. Assim, enquanto na visão da igreja oficial a missa é o rito central, para os devotos ela é apenas a introdução ao que verdadeiramente buscam. Enquanto para a igreja o ponto alto da missa é o momento da consagração, para os fiéis o momento chave é aquele em que o padre benze a água, as flores, os terços e quaisquer outros objetos, e dá a benção à família. Qualquer romeiro explica que busca chegar ao santuário antes da missa das 11 para receber as bênçãos.

Na concepção dos devotos, o padre é um dos instrumentos das graças de Cristo milagroso; nas intençōes evangelizadoras dos padres, os devotos são a sua clientela, potenciais consumidores ortodoxos dos bens distribuídos, das idéias veiculadas pelo catolicismo oficial. Enquanto para a hierarquia o culto à imagem é algo lateral e secundário, os fiéis se relacionam na verdade é com a imagem, embora não contestem, não questionem, mas aceitem e usem os ritos oficiais como dados tradicionais da fé. Nada resume melhor essa oposição complementar entre devoto-igreja do que a palavra de uma peregrina:

"Lá tem uns padres muito simpáticos, celebram uma missa muito gostosa, mas o poder mesmo está com Cristo Crucificado."

Na mesma linha de pensamento, os devotos como que criam seus proprios intermediários, estabelecidos não pela hierarquia, mas pela sua prática devocional. Enquanto alguns poucos peregrinos afirmam que apenas têm ido uma vez para pedir, outra para cumprir a promessa, acrescentando que "se houver necessidade a gente volta", a práxis comum é de se estabelecer uma relação perene fiel-santuário. Alguns devotos passam, a partir de determinados fatos, a serem intermediários entre a família e o grupo social e Cristo milagroso. É como se esses fiéis, indo ao local freqüentemente, transmitam dons para os outros. O Cristo de Porto das Caixas assume então um papel doméstico, invocado em 
todas as situaçōes difíceis. Portadores do "sagrado" e emissários do "deus-protetor", esses devotos cumprem uma função e assumem um papel sacerdotal, subvertendo mecanismos tradicionais da igreja oficial. Assim, na produçāo e reprodução da crença, os "devotos", enquanto sujeitos sociais, promovem uma aventura pelas regiōes inacessíveis da mente, $e$ como o mostra Mary Douglas "fazem também uma aventura além dos limites da sociedade. $\mathrm{E}$ ao retornarem dessas regiōes inacessíveis trazem consigo um poder inacessível àqueles que tenham permanecido sob o controle de si mesmos e da sociedade" (1966:118).

\section{CURA E MILAGRE}

"Porque se ele ou ela não crê suficientemente é como colocar gelo na água quente. É pedir em vão."

O siginificado etimológico de cura é "cuidado", de "cuidar". Este termo, derivado de gestos pertinentes às relações cotidianas, entra no vocabulário médico como uma das etapas e o resultado do sistema terapêutico, lembrando procedimentos técnicos. Consultando-se uma série de dicionarios médicos (Polisuk e Goldfeld, 1988; Dorland's Illustrated: 1965 (24 ed.); Blakiston: 1982 (2ªd.); Cécil Wakeley Ed. 1953) todos repetem o mesmo conteúdo para o conceito de cura.

"Retorno de um organismo a seu estado funcional normal".

"Tratamento a que se submete o doente, seja qual for o resultado do mesmo." "Tratamento bem sucedido de uma doença."

Apenas um dos dicionários consultados acrescenta a essas a definição de cura mental como sendo "o uso da sugestão ou da fé para tentar curar as doenças, principalmente as físicas."(Blakiston, 1982:289).

Observa-se nas enunciações acima uma ênfase ora no resultado, ora no processo, e em todos os casos, uma restrição do conceito aos efeitos no corpo, da própria intervenção no corpo.

Um salto qualitativo nesse nível de reflexāo aparece em Goldstein (1952:272). $O$ autor define cura como "reconstituição funcional satisfatória para o doente e para o médico na ordem anatômica", mas acrescenta que esse fenômeno é sempre acompanhado de perdas essenciais para o organismo e ao mesmo tempo, do reaparecimento de uma nova ordem, tanto no campo somático como no campo psíquico. Canguilhem acrescenta a esse pensamento de Goldstein a idéia de que a doença não é uma variação de estado de saúde: ela é uma nova dimensāo da vida, pois "a vida nāo conhece reversibilidade: ela admite rẹparações" (1982:149, 158).

Para os devotos de Porto das Caixas, cura tem um significado mais totalizante do que o da definição médica $e \hat{\epsilon}$ importante reconstituir sua abrangência através das falas.

"Cura é assim: meu filho tem um problema de ouvido. Eu levei ele ao médico, corri em tudo quanto há de lugar e não obti 
cura. Entâo a gente parte para procurar outros recursos, pra procurar o milagre. A gente põe toda a fé, toda a energia ali e consegue. Então a gente parte pra cumprir a promessa."

"Receber uma cura depende de muita coisa. A pessoa vai porque quer ficar livre de algum problema, porque a gente recorre por muitos motivos, de saúde, de mente, da família. Mas depende da fé de quem quer ser curado e daqueles que pedem com ela. Porque se ele ou ela não crê, pede em vão, é como colocar gelo na água quente."

A partir dos devotos, depreende-se que:

A cura aqui se refere ao fenômeno pelo qual as pessoas recuperam a saúde física e mental, mas também serve para denominar a recuperação da segurança, do bem-estar, da honra, do prestígio, de tudo aquilo que seja reordenação do caótico, do imprevisível, do negativo em termos religiosos-ideológicos ou pessoais, em relação a si mesmo, aos outros e ao mundo.

No entanto, existe uma hierarquização classificatória, observada nos depoimentos entre cura, milagre, graça e benção.

A categoria milagre se reserva para significar consecução de um bem (saúde ou bem material ou espiritual) considerado impossível de ser atingido pelas forças naturais ou pelos recursos ao alcance do devoto. Milagres serão, pois, a recuperação da saúde para doentes desenganados da medicina, de aleijados, de cegos. Mas se considera milagre também, para a família sem recursos financeiros para fazer realizar uma intervenção na vista de uma criança, intervenção tida como imprescindível pelos médicos, a recuperação por meios sobrenaturais dessa vista. Milagre também será para o devoto de classe social elevada a recuperação do filho drogado ou a volta ao lar da filha que desaparecera.

O termo graça, "alcancei uma graça", é usado para explicar situações de cura, ou de bom êxito em que, havendo recursos naturais ao alcance do devoto, ele os usa, mas ao mesmo tempo invoca o santo protetor. Porque "o médico tratou, mas quem curou foi o Cristo, que eu gritei por ele sem parar". "Se Deus não quer, as coisas não acontecem".

Outra categoria usual é a benção. Trata-se de um ato de prevenção contra o mal, contra as forças adversas. Muitas pessoas vão ao santuário apenas para pedir a bençāo do Cristo Crucificado para sua família e amigos. Diz uma das entrevistadas:

"Vai, leva as crianças. Até é bom porque entrega elas pra Cristo, pede a bênçâo, benze elas". Muitos dos devotos dizem estar no santuário para fazer a consagração da família ou para pedir graças e bençãos para todos.

Com referência à classificação mencionada, ao mesmo tempo em que é possível detectá-la a partir dos discursos, dá para perceber a ambigüidade desses termos na linguagem corrente entre os devotos: milagres são chamados graças e bênçãos, assim como graças são classificadas hiperbolicamente como milagres. A chamada "sala dos milagres" está cheia de ex-votos comprovando "graças e bênçãos".

$\mathrm{Na}$ verdade, nem todas as pessoas que procuram o santuário conseguem exatamente o que vão em busca, isto é, a cura em termos materiais e visíveis no corpo. 


\begin{abstract}
"Às vezes a pessoa já pecou muito e então Deus não deixa ela recuperar a saúde, mas lhe dá a graça da conversão, da aceitação de sua vontade." (devoto).
\end{abstract}

"Nem todos os que vêm aqui alcancam o que pedem, mas ninguém sai revoltado, ou perde a fé. $O$ Cristo lhe dá a graça de um conforto espiritual." (devoto).

"A gente vem, não só para pedir a cura, mas para pedir a força de aceitar o sofrimento." (devoto).

Em outras palavras, a "conformidade" com a vontade suprema, "conquista" dos devotos através das peregrinações, se considera também cura, ou seja, modificação no modo de conceber o impensável para aceitar o absurdo, o inexplicável. Como bem diz Lévi- Strauss:

"A cura consistiria em tornar pensável uma situação inicialmente impensável em termos afetivos $e$ aceitáveis para o espirito, as dores que o corpo se recusa a aceitar." (L. Strauss, 1970:216).

E aí não importa que o rito não corresponda à realidade objetiva: o devoto acredita e se recoloca num esquema unificado e ordenado.

Indiscutivelmente, o elemento que aparece nos relatos intimamente ligado à cura é a fé: "na hora da necessidade é que a fé da gente aparece"."Na hora do sofrimento a gente tem que pedir com muita fé, com todas as nossas energias". No seu texto sobre "Eficácia Simbólica" Lévi-Strauss (1970) reflete o papel da fé na terapêutica indígena dizendo que ela se fundamenta a) na crença do feiticeiro na efetividade de suas técnicas; b) na crença do doente ou da vítima no poder do feiticeiro; c) na fé e na expectativa do grupo que age como uma espécie de campo gravitacional no interior do qual a relação entre o feiticeiro e a vítima ou doente se definem".

Essas constatações de certa forma resumem o quadro da "crença e da fé" no contexto das relações sociais. Esse último pensamento faz pensar na idéia do mal também como benção, porque o sofrimento é o meio por excelência do devoto se voltar para a divindade e de reaviver a sua fé. É como se a fé viesse concomitantemente ao mal, fato que também foi detectado por Durkheim nas religiōes primitivas (1978:227). De qualquer forma ela expressa um anseio de transformação da situação individual, a tal ponto que o fiel tem certeza da intervenção sobrenatural "de acordo com a vontade de Deus". Como refere Mary Douglas: "o ritual espera poder descobrir poderes e verdades que não podem ser alcançados através do esforço consciente."(1966:117).

A fé reforça o grupo dos crentes, na medida em que sua explicitação socializa as situações problemáticas e as intervençōes miraculosas, como demonstram os depoimentos:

"Depende da fé de quem quer ser curado e daqueles que pedem com ele."

A jornalista miraculada relata o epiś́dio de uma família da Holanda que procurou saber a hora de maior afluência de pessoas ao santuário e depois reuniu a comunidade 
para (lá da Holanda, onde ouviu sobre Porto das Caixas) pedir pela filha que sofria ataques epiléticos e tinha comportamento considerado anormal. A menina ficou curada. A família veio ao Brasil, diretamente ao santuário, para manifestar a gratidão pela recuperação da filha. Remetendo ainda a Mary Douglas, este fato lembra que a energia para comandar poderes especiais de cura vem àqueles que conseguem abandonar o controle racional por algum tempo (1966:118).

A presença coletiva dos devotos no centro de peregrinaçōes e o testemunho das graças recebidas na sala dos milagres reforçam a fé dos crentes e reafirmam suas crenças e práticas. Apesar das situações de sofrimento e desespero serem apresentadas no plano individual, segundo Mauss $(1979,119)$, "o indivíduo não faz mais do que atribuir a seus sentimentos pessoais uma linguagem que nāo criou". No milagre, a fé coletiva precede a experiência pessoal.

De acordo com Durkheim (1978:228), "uma filosofia pode elaborar-se no silêncio da meditação interior, mas não uma fé. Pois uma fé é, antes de tudo, calor, vida, entusiasmo, exaltação de toda a atividade mental, transporte do indivíduo acima de si mesmo. As crenças são ativas apenas quando compartilhadas".

\section{PRÁTICAS RELIGIOSAS}

" $E$ então eu fiz uma promessa de dar o corpozinho dela em cera."

"Meu marido prometeu vir sete semanas seguidas."

"Eu levo a água e tomo, todos tomam pra qualquer dificuldade."

O fenômeno da cura vem habitualmente na concepção dos devotos, como consequiência de um pedido de fé, e vinculado a uma promessa que constituiria o centro das práticas religiosas dos devotos do Cristo de Porto das Caixas. É como se a fé fosse o elemento espiritual da cura e a promessa o seu elemento material. $O$ devoto pode ou não estar pessoalmente na hora dos pedidos, mas, em geral, todos voltam ao santuário para agradecer pelos dons recebidos.

Poder-se-ia deduzir que as promessas são a formalização de uma relação de troca entre o crente e o seu orago, porque "eu dou em virtude de ter recebido", colaborando com essa concepção o termo comumente usado de "pagar a promessa". No entanto, uma análise mais profunda demonstra que é quase uma exceção o comportamento de s6 se ir ao santuário pelo milagre e para cumprir a promessa.

O mais habitual é que, a partir das graças recebidas do Cristo miraculoso, inicia-se uma relação muito particular, contínua de fidelidade, incluindo consagração pessoal da família, assim como visitas freqüentes ao local, reorientando-se a vida religiosa do peregrino para essa devoção particular. Expressões como "em tudo eu recorro a Jesus de Porto das Caixas"; "viemos para consagrar a familia, pedir bençãos" são comuns nos diferentes depoimentos. Há inclusive, entre os devotos entrevistados, um caso extremo da 
devota miraculada que passa a dedicar sua vida profissional de jornalista à divulgação da devoção e dos fatos extraordinários que ocorrem no local.

Ligadas às promessas há uma série de outras práticas exercidas pelos fiéis. Destaca-se a romaria, que consiste em se deslocar para visitar o santuário, mas em espírito de penitência. Os devotos fazem questão de distinguir, "não é uma festa", "não é uma excursão".

Outro rito que chama atenção pela importância que lhe dão os fiéis é a água benzida no local miraculoso. Nenhum devoto sai de Porto das Caixas sem carregar sua garrafa de água que considera "milagrosa", "benta", assim como outros objetos (terços, flores, velas) no fim da missa. Tais objetos passam a ser considerados sagrados e portadores dos mesmos poderes miraculosos (talvez em menor escala) que a imagem de Cristo Crucificado.

Essa reflexão sobre as práticas pode ser remontada ao papel do ritual na cura religiosa. Marcel Mauss (1979) lembra que se deve reconhecer a possibilidade de uma intervenção mágica (religiosa) sempre presente na mente dos crentes e que é humano e natural esperar por benefícios materiais da representação de símbolos cósmicos. $\mathrm{O}$ ritual fornece um enfoque, um método de lembrança e um controle da experiência, ajuda a selecionar experiências para concentração da atençāo, a expressar, a provocar a recriação.

É claro que se espera dos rituais de cura que eles afastem a morte, mas não é apenas a eficácia instrumental que deve ser extraída da ação simbólica. O outro tipo de eficácia é alcançado na ação em si, nas asserções que ela faz e na experiência que leva sua marca. $\mathrm{Ou}$ o milagre é pura ilusão ou não é. E se não é, então os símbolos têm poder de operar mudanças que ocorrem em dois níveis: o da psicologia individual e o da vida social. Os símbolos atuam em nível psicossomático para o doente e interfere nas atividades e relações do grupo de crentes, reordenando-as: esta é a lição que se retira desta pesquisa e é o que tem sido analisado por Mauss (1979) e Mary Douglas (1966).

\section{CONSIDERAÇÕES FINAIS}

O esforço para entender a busca da cura dentro da cosmovisão do catolicismo popular faz o pesquisador encontrar e reviver suas próprias situaçōes-limite e distinguir tal representação de outras formas de solução de conflitos, sobretudo daquelas que revelam a impotência humana ante a dor, o sofrimento, a doença e a morte. $O$ breve estudo aqui traçado ajuda a perceber que:

a) a busca da cura através de meios sobrenaturais não é privilégio de nenhuma classe social no Brasil. Ela permeia todos os estratos de nossa sociedade, embora cada estrato tenha sua forma peculiar de dar significado a suas experiências e práticas;

b) o elemento motivador para a religião dos milagres são situaçōes de extremo sofrimento, desespero frente à doença e/ou à iminência da morte, assim como problemas de ordem moral, pessoal e social que configurem o caos;

c) o fenômeno de cura no catolicismo popular está basicamente referido à fé. Nisso difere, por exemplo, de outras crenças populares brasileiras. Difere-se por exemplo, da representação da cura no candomblé, no espiritismo e no pentecostalismo, como o mostra 
a pesquisadora Mirian C. Rabelo (1992). Segundo esta autora, para os pentecostais a doença É resultante da ação de entidades do mal que invadem o corpo. A cura se processa pela expulsão pública do mal através de um ritual de luta. Para os espíritas, grande parte das doenças resulta da ação de espíritos obsessores e a cura se realiza através da educação desses espíritos menos desenvolvidos num ritual que representa essa atividade pedagógica. No candomblé, a doença é causada pela ação prejudicial dos seres humanos ou de entidades sobrenaturais. A cura se dá num ritual de alianças entre entidades e humanos para recriar uma dinâmica de negociação.

Difere-se também da cura tal como representada no sistema médico oficial, que reduz ao corpo o espaço da intervenção e da mudança. A cura no catolicismo popular tem em comum com todas as terapias religiosas: a crença na eficácia "mágica"; o círculo gravitacional energético do grupo de crentes que partilha as mesmas expectativas; e o sentido de "ordenamento social" a partir da intervenção milagrosa;

d) embora a busca da cura pela religião atribua um caráter utilitário e prático aos atos e comportamentos dos fiéis, esses atores sociais ultrapassam tal mentalidade quando criam relações de fidelidade entre o devoto e o santo, como bem o refere Durkhein: "todas as religiōes são em certo sentido espiritualistas, pois as potências que elas colocam em jogo são antes de tudo espirituais e é sobre a vida moral que elas têm a função de agir." (1978: 224);

e) olhando esse tema a partir do campo da saúde, mais uma vez se reafirma a complexidade que envolve o conceito de saúde e doença, vida e morte, ultrapassando e perpassando a realidade biopsicossocial. Em outras palavras, embora o campo de intervenção médica se circunscreva tecnicamente aos contornos e ao interior do corpo, o médico como cientista, artista ou técnico não pode desconhecer a complexidade que envolve qualquer problema ou situação de saúde e doença. 


\section{REFERÊNCIAS BIBLIOGRÁFICAS:}

BERGER, P. (1967). El Dosel Sagrado. Buenos Aires: Amorrurtu.

BLACKISTON. (1982) (2ªd.). Dicionário Médico, Sāo Paulo. André Ed. Leda.

BOURDIEU, P. (1974). Economia das Trocas Simbólicas. São Paulo: Ed. Perspectiva

CANGUILHEM, G. (1982) (2 Ed.). O Normal e o Patológico. Rio de Janeiro: Ed. Forense Universitária.

DORLAND'S ILLUSTRATED (1965) (24 Ed.). Medical Dictionary. London: W. B. Saunder Co.

DOUGLAS, M. (1970). Pureza e Perigo, São Paulo: Ed. Perspectiva.

DURKHEIM, E. (1978)."As formas elementares de vida religiosa". In: Durkheim (coleção pensadores), pp. 203-245. Săo Paulo: Editora Abril.

GOLDSTEIN, K. 1952. La structure de l'organisme. Paris Gallimard.

LÉVI-STRAUSS, C. (1970). "Magia e Religiāo", In Antropologia Estrutural, I, pp. 183-254, Rio de Janeiro: Ed. Tempo Brasileiro.

MARX, K. \& ENGELS. (1972). "The Early Marx". In: The Marx and Engels Reader (W. W. Norton and Co.) pp. 7-110 New York: Princeton University E.

MAUSS, M. (1974). Sociologia e Antropologia. vol. 1, São Paulo: Epu/Edusp,. 1979. Antropologia. São Paulo: Editora Ática.

POLISUK \& GOLDFELD. (1988). Pequeno Dicionário de Termos Médicos. São Paulo: Livraria Ateneu.

RABELO, M. C. (1992). "Religião e Cura: algumas reflexð̄es sobre a experiência religiosa das classes populares urbanas:" XVI Encontro Anual da ANPOCS 1992 (mimeos).

WAKERLEY, C. (1953). The Faber Dictionary. London: Faber and Faber Ed.

WEBER, M. (1971). "Religião", In: Ensaios de Sociologia, Parte III, pp. 309-408, Rio de Janeiro: Zahar Editores.

WOLF, E. (1970). "OCampesinato a a Ordem Ideológica" In: Sociedades Camponesas, pp. 131-146, Rio de Janeiro: Zahar Editores.

ZALUAR, A. (1980). "Milagre e Castigo Divino" Religiäo e Sociedade 5:161-189. (1973) "Sobre a 16gica do Catolicismo Popular" Dados, 27:173-194. 



\title{
5
}

\section{MEDICINAS POPULARES E "PAJELANÇA CABOCLA" NA AMAZÔNIA}

\author{
RIYMUNDO HEIRALDO MALÉS
}

Entre as várias medicinas populares praticadas no Brasil, estudamos especialmente a chamada "pajelança cabocla", muito popular sobretudo na Amazônia rural, composta por um conjunto de práticas de cura xamanística, com origem em crenças e costumes dos antigos índios Tupinambás, sincretizados pelo contato com o branco e o negro, desde pelo menos a segunda metade do século XVIII".

A pajelança cabocla se fundamenta na crença nos "encantados", seres invisíveis que se apresentam durante os rituais incorporados no "pajé" (isto é, o xamã), que é a figura central da sessão de cura. Começando pela descrição de um ritual de pajelança típico, tal como pude observar numa povoaçāo de pescadores do litoral do Pará, Itapuá ${ }^{*}$, prossigo analisando sua relação com o contexto social, visando também mostrar a importância dessas práticas de cura para as populações nativas da região.

A sessão de pajelança (ou "trabalho", como é chamado pelos participantes) é realizada com a assistência de várias pessoas convidadas. Ocorre sempre à noite, começando por volta das vinte horas e terminando já pela madrugada (perto de uma ou duas horas, normalmente). Quase sempre é patrocinada por um doente ou por seu parente (marido, quando se trata de mulher), que é chamado de "dono do trabalho". Comparecem, além do doente para o qual é feita a sessão, outras pessoas (doentes ou não-doentes), muitas delas a convite do próprio pajé, ou do dono do trabalho, ou de seus parentes.

$\mathrm{O}$ "trabalho" começa com uma oração feita pelo pajé, diante de um santuário ou mesa, onde são colocadas as imagens e estampas de vários santos católicos. Durante essa oração, o pajé "entrega" a Deus o seu espírito, que irá deixá-lo por algumas horas,

- Cf., a respeito, o Livro da Visitaçāo do Santo Ofício ao Pará, que apresenta, nas denúncias e confissões, relatos de sessð̃es que hoje seriam vistas como de pajelança (Lapa, 1978).

* Trata-se de povoação pertencente ao município de Vigia, onde fiz trabalho de campo, nela residindo inicialmente durante quatro meses (dezembro de 1975 a abril de 1976) e, mais tarde, voltando ali inúmeras vezes, num período que vai até o ano de 1985 , quando completei a pesquisa para escrever minha tese de doutorado (Maues, 1987). 
para dar lugar aos "caruanas" (ou "encantados") que nele se incorporam. Após a oração, o pajé senta em um banquinho, cadeira ou rede de dormir. Em sua mão direita está o maracá $^{*} \mathrm{e}$, na esquerda, três penas coloridas. Concentra-se e, de repente, chega o primeiro guia ou cavalheiro. A partir desse momento, não é mais o pajé que está falando ou agindo diante das pessoas, mas sim o "caruana" que se apoderou de seu corpo. Durante todo o trabalho, embora se sucedam os "caruanas", o pajé permanecerá inconsciente, sem ter conhecimento de nada do que acontece, segundo afirmam os informantes.

Recebendo o primeiro guia, a voz do pajé se modifica, adotando o timbre próprio do "caruana" que nele se incorporou; dá boa-noite aos presentes e canta sua "doutrina", agitando o maracá e dançando pelo salão. Trata-se de um cântico inicial para "abrir as correntes" (isto é, dar início à própria sessão de cura), durante o qual o "caruana" pede a bênçāo dos santos a todos os presentes e também se refere ao "encantado" mais importante na região: o "rei Sebastião". Em seguida, conversa com os assistentes, despede-se e dá lugar a outro "caruana", que também dança e canta sua doutrina.

O clima do "trabalho" não é de seriedade absoluta. Todos riem quando um "caruana" canta uma doutrina engraçada. Os próprios "caruanas" brincam com as pessoas, dizendo piadas e, especialmente, fazem gracejos com o ajudante (ou servente) do pajé, que retruca no mesmo tom. A todo momento o servente oferece ao pajé um cigarro "branco" (isto é, comum), além do cigarro tauari (permanentemente aceso), um pouco d'água ou chá de uma erva chamada cidreira. O cigarro tauari, enrolado com a casca de uma planta chamada tauarizeiro, é fumado ao contrário, com a brasa dentro da boca; ao invés de chupar a fumaça, como se faz com o cigarro "branco", o pajé a sopra com força, para fazer defumação do ambiente, dos objetos e dos doentes.

Alguns guias ou "caruanas" que chegam pedem para ver o doente a quem o trabalho é destinado, mandam defumar-lhe o corpo ou passar cachaça em sua pele. Mas somente um guia especial é que faz o tratamento propriamente dito. Trata-se do "mestre curador", que também chega dançando e cantando sua doutrina:

"Eu venho de longe

No meu cavalo marinho.

Eu sô cavalhêro falado

Eu sô mestre Joãozinho".

E, dirigindo-se ao doente, prossegue o canto:

"Eu recebi um recado

da vossa senhoria

Comigo queria falá

Por isso eu vim neste dia (...)".

Em seguida, o doente para quem se realiza o "trabalho" é chamado para sentar-se numa cadeira ou banco no centro do salão e, a partir daí, iniciam-se os procedimentos

* O maracá é um chocalho feito com a cabaça de uma planta chamada "balde". Pode ser fabricado localmente (em Itapuá e outras povoaçð̋es rurais), mas também pode ser comprado em casas de comércio especializadas, na capital do Estado (Belém). As penas são de arara, sendo também vendidas nas mesmas casas comerciais. 
necessários para realizar sua cura. Os outros doentes presentes são chamados e recebem o tratamento feito pelo pajé. Mesmo pessoas que não se sentem doentes aproveitam a oportunidade para tomar passes. Quando não há mais ninguém que queira se "consultar" ou tomar passe, o mestre curador se despede, deixando o corpo do pajé e dando lugar a outro "caruana".

Daí a pouco chega a "linha das princesas". Tratando-se de um pajé do sexo masculino, sua voz passa a imitar uma mulher. Depois de "baixarem" várias princesas, o trabalho se encerra, com a vinda de um príncipe chamado mestre Domingos. Ele fala da "cidade de Maiandeua, onde reside o rei de todos os encantados, o rei Sebastião". Despede-se de todos, cantando e dançando. Faz uma série de recomendações, especialmente ao ajudante do pajé, para que não se descuide no momento em que abandonar o corpo do "aparelho" (pajé), para que este não caia ao chão e se machuque. Em dado momento, cessa o canto abruptamente e o pajé parece estar desacordado, sendo amparado pelo servente. Este reza o Pai-Nosso, a Ave-Maria e, em seguida, bate com a mão direita aberta sobre sua testa, chamando-o pelo nome e mandando que ele acorde. O pajé volta a si, dá boa-noite a todos e passa a se comportar normalmente. Está encerrado o trabalho e todos se retiram para suas casas.

A pajelança cabocla é uma forma de culto mediúnico, constituído por um conjunto de crenças e práticas muito difundidas na Amazônia, que já têm sido estudadas por outros pesquisadores * Tendo provavelmente, segundo Galvāo (1976), origem na pajelança dos grupos tupis, esse culto, que hoje se integra $\mathrm{cm}$ um novo sistema de relações sociais, incorporou crenças e práticas católicas, kardecistas e africanas, recebendo atualmente uma forte influência da umbanda. Seus praticantes, entretanto, não se vêem como adeptos de uma religião diferente, considerando-se "bons católicos", inclusive os pajés ou curadores que presidem as sessões xamanísticas.

Embora se possa estabelecer uma homologia entre santos católicos e "encantados" da pajelança, é necessário, aqui, enfatizar suas diferenças e aprofundar um pouco a caracterização destas últimas entidades. Enquanto os santos se caracterizam por suas numerosas estampas e imagens (ou "semelhanças" deixadas por Deus na terra, segundo os informantes), os "encantados" não são representados de nenhuma forma, sendo também, normalmente, invisíveis a nossos olhos. Não obstante, assim como se acredita que os santos se manifestam às vezes diante das pessoas, em aparições a devotos privilegiados, o mesmo se diz que fazem os "encantados", só que de forma bem mais freqüente e de modo bastante variado. Essa crença, em parte, é responsável pela variedade de denominações que recebem. Distinguem-se, entre eles, os "encantados" "do fundo" e "da mata", conforme o lugar onde habitam: o fundo dos rios ou a floresta.

Os "encantados-do-fundo" são designados como "bichos-do-fundo", "oiaras" ou "caruanas". A denominaçāo "bicho-do-fundo" provém da crença de que os "encantados" podem se manifestar sob a forma de diferentes animais aquáticos, que vivem "no fundo" dos rios, como peixes, cobras, botos, etc. Manifestando-sc, porém, com forma humana, geralmente nas zonas de "mangal" (manguezais), à margem dos rios e igarapés, os

* Entre eles, Galvāo (1976), Figueircdo (1976), Figueiredo \& Vergolino e Silva (1972) e Salles (s.d., 1969). Esses estudos, entretanto, foram realizados em áreas diferentes da Amazônia e com uma perspectiva teórica e objetivos diversos do presente trabalho. 
"encantados" surgem na condição de "oiaras". Já os "caruanas" (também conhecidos como "guias" ou "cavalheiros") são aqueles que se manifestam sem que se possa visualizar sua forma, nas sessōes xamanísticas dos pajés, incorporando-se neles. Nestes casos surgem como entidades benéficas, com a finalidade de curar.

Outra faceta dos "encantados" é a sua "malineza". Concebidos como seres perigosos, podem provocar doenças nos seres humanos, além de outros males. Por isso, é necessário ter cautela com eles, não só pedindo a proteção divina contra os males que podem provocar, como adotando atitudes respeitosas no momento em que se passa pelos locais onde costumam manifestar-se, assim como quando se está assistindo ao trabalho de um pajé.

Os "encantados-do-fundo" podem provocar "doenças", como o "mau-olhado", a "flechada-de-bicho", a "corrente-do-fundo" e, ainda, manifestando-se na forma de um boto que se transforma num belo rapaz, são capazes de possuir sexualmente as mulheres". Além disso, são também perigosos por costumarem atrair as pessoas para suas moradas "no fundo", onde elas também se transformarão em "encantados".

Os "encantados-da-mata" ("anhanga" e "curupira") também provocam o "mau-olhado" e têm o poder de "mundiar" as pessoas, isto é, fazê-las perder-se na floresta. Isto acontece, sobretudo, no caso de caçadores que cometem abusos, matando persistentemente um só tipo de animal ou uma quantidade de caça superior às suas necessidades.

Isto, aliás, é um elemento importante na ideologia regional, desde que esses seres funcionam também como uma espécie de defensores míticos da floresta, dos rios, dos campos e dos lagos. Tudo tem sua "mãe" (um "encantado"): abusos sāo castigados pela "mãe do rio", quando este é poluído, pela "mãe do mato", quando a floresta é devastada,e assim sucessivamente. Parece porém que, em certas áreas, "os curupiras foram embora" desde que a destruição das motosserras foi mais poderosa.

Tudo isso se constitui em elementos relevantes de uma forma de culto que é também uma prática médica local, cuja importância é tanto maior em Itapuá, como em centenas de outras povoaçōes e vilas do interior da Amazônia. São extremamente precários ou inexistentes os serviços de saúde oferecidos por pessoal treinado dentro da tradição da medicina ocidental. Ademais, mesmo que essas pessoas possam utilizar serviços médicos de fora de suas comunidades, isso é feito concomitantemente com a utilização da medicina local, cuja abrangência é muito mais ampla, envolvendo crenças religiosas, conhecimento da natureza (sobretudo plantas e animais), relações sociais (família, vizinhança, povoação, outras localidades), bem como trocas econômicas. cerimoniais, participação em rituais, diversão, etc.

Por outro lado, a pajelança cabocla surge como uma das várias medicinas populares na Amazônia, desde que o pajé não é o único especialista local no tratamento de doenças. Além dele, existem o "experiente", a parteira, o benzedor ou a benzedeira, o "espírita"

O "mau-olhado" é bastante conhecido na literatura antropológica (Cf. Reminick, 1974, Spooner, 1970, entre outros). Quanto à "flechada-de-bicho" e à "corrente-do-fundo", trata-se de conceitos locais que designam "doenças" capazes de provocar, a primeira, dores localizadas em partes do corpo, como se a pessoa tivesse sido atingida por uma flecha; $e$, a segunda, incorporação descontrolada por encantados e espíritos, indicativo de um possível "dorn" xamanístico. As historias sobre a sedução de mulheres pelo boto têm sido muito difundidas e abordadas pela literatura, pelo cinema e por trabalhos de cunho antropológico.

** Este 6 o título de uma dissertação de mestrado em antropologia, que estuda o campesinato na região de Santarem, no Estado do Pará (Cf. Lins e Silva, 1980). 
(alguém que, seguindo o kardecismo, também atende os doentes) e o "farmacêutico" (isto é, o dono de farmácia, que também receita remédios). Mais recentemente, com o desenvolvimento do pentecostalismo, têm penetrado no interior da Amazônia muitas igrejas voltadas para a cura de doenças, através do exorcismo e do poder do Espírito Santo.

É, no entanto, a figura do pajé que ainda desempenha, em áreas tradicionais e de colonização mais antiga, como o litoral paraense e as localidades ao longo dos rios principais, especialmente o Amazonas, o papel do médico popular mais importante. Ademais, o pajé pode também exercer as funções do "experiente" (que conhece um grande número de remédios da flora e da fauna), do benzedor ou da benzedeira (que benze os doentes para propiciar a cura) e, se for mulher, da parteira (sendo, neste caso, muito solicitada, por ser "parteira de dom", isto é, que trabalha com assistência dos "encantados"). Nenhum desses especialistas pode, no entanto, por si só, exercer as funções específicas do pajé, que ć um xamã inspirado.

Não se pode, pois, limitar a função do pajé apenas ao tratamento de doenças. A pajelança cabocla tem implicações de caráter religioso $\mathrm{c}$, por isso, há uma longa história de conflito entre as atividades xamanísticas dos pajés e a posição da Igreja Católica oficial. Hoje, certamente, essa oposição se encontra atenuada. Todo pajé se considera um "bom católico", participando do ritual e das crenças do catolicismo na mesma medida em que os outros homens e mulheres de sua comunidade. Não obstante, os pajés estão conscientes da oposição que os sacerdotes católicos colocam (ou mais acentuadamente colocavam no passado) a suas atividades e lembram, com frequiência, as perseguições, até mesmo de caráter policial, de que foram vítimas em épocas anteriores.

Por outro lado, para o pajé o exercício da função xamanística envolve uma permanente contradição. De um lado esse exercício é visto, pelo próprio pajé, como penoso, pois envolve um grande número de obrigações rituais e de atendimento das pessoas, mas, de outro, ele confere poderes que são estimados pelos seus detentores. Em razão disso, nāo são raros os relatos de tentativas feitas por pajés no sentido de "roubar" ou "tirar" os poderes dos outros. Por outro lado, o abandono da função xamanística é algo que, segundo as concep̧̧ões locais, não pode ficar impune. Antes de se tornar xamã, o pajé sofre de uma doença chamada localmente de "corrente-do-fundo", que é indicativa do próprio dom xamanístico. No tratamento a que é submetido o "doente de corrente-do-fundo" é possível afastar os "caruanas", de tal forma que a cura se processe sem que a pessoa precise se tornar xamã. Em certos casos, porém, isso não é possível, especialmente se se trata de um dom "de nascença" e, nesse caso, a cura nunca é completa. Apenas cessam os sintomas físicos, as dores, os incômodos, as perturbações e as possessōes descontroladas. Mas, segundo as representaçôes locais, o pajé nunca está realmente curado da doença que o acometeu, pois a cura completa implicaria numa perda do dom xamanístico.

Outro aspecto contraditório do exercício da função xamanística está ligado às ambigüidades inerentes à figura do pajé que, freqüentemente, é pensado também como feiticeiro, especialmente se for mulher. Alguns pajés, mesmo que sejam respeitados por seus poderes, são no entanto malvistos pela fama que possuem. É o caso, por exemplo, do conhecido pajé Manezinho ${ }^{*}$, de Itaporanga, que tem também a fama de "mexer" com as

* Todos os nomes de pessoas vivas da área em estudo são fictícios. 
mulheres (procurando aproveitar-se sexualmente delas), sobretudo aquelas em tratamento com ele, $e$ a respeito de quem surgem acusações de feitiçaria. Um dos poucos pajés sobre quem não pesam acusaçōes, de quantos conheci, é o cego Ramiro, a despeito de ser considerado o mais poderoso curador de Itapuá. Mesmo no seu caso, porém, coloca-se uma forma de ambigüidade, pois, segundo ele mesmo admite, sua cegueira foi provocada por seus próprios "caruanas", quando tentou eximir-se, no passado, do exercício da função xamanística.

Um possível caminho para entender essa ambigüidade inerente à figura do pajé radica numa reflexão a respeito da idéia de indivíduo em nossa sociedade. Pelo menos desde a publicação de um famoso trabalho de Mauss (1974), não constitui nenhuma novidade afirmar que as noções de indivíduo e pessoa são construídas socialmente. Estudando a elaboração histórica da noção de pessoa como um "eu" individualizado, desde as concepções da sociedade tribal do ser humano como um personagem que ocupa seu lugar bem demarcado nas dramatizações do ritual, a partir de uma classificação que implica posicionamento hierárquico, esse autor abre caminho para uma série de formulações que vão se refletir na antropologia moderna.

Nessa linha se encontra o posicionamento teórico de Dumont (1972), que analisa o sistema de castas hindu, mostrando o contraste entre os ideais de igualdade, liberdade $e$ individualismo predominantes na sociedade euro-americana e os conceitos de hierarquia e casta, pertinentes ao sistema indiano. São essas também as questões retomadas por Roberto da Matta, na sua tentativa de interpretação da sociedade brasileira, para quem, historicamente, a noção de indivíduo natural ou empiricamente dado recebe dois tipos de elaboração. Num caso,

"(...) tomou-se a sua vertente mais individualizante, dando-se ênfase ao 'eu individual', repositório de sentimentos, emoções, liberdade, espaço interno, capaz portanto de pretender a liberdade e a igualdade, sendo a solidão e o amor dois de seus traços básicos (...), e o poder de optar e escolher um dos seus direitos fundamentais. Nessa construção que corresponde à construçäo ocidental a parte é, de fato, mais importante que o todo. E a noção geral, universalmente aceita, é a de que a sociedade deve estar a serviço do individuo, o contrário sendo uma injustiça que importa corrigir" (Da Matta 1979:172).

Noutro caso, dá-se justamente o oposto, pois nele a elaboração da idéia de indivíduo tende a enfatizar o seu lado social:

"Aqui, a vertente desenvolvida pela ideologia não é mais a da igualdade paralela de todos, mas a da complementariedade de cada um para formar uma totalidade que só pode ser constituida quando se tem todas as partes. Em vez de termos a sociedade contida no indivíduo, temos o oposto: o indivíduo contido e imerso na sociedade. É essa vertente que corresponde à noção de pessoa como a entidade capaz de remeter ao todo, 


\section{e não mais à unidade, e ainda como o elemento básico através do qual se cristalizam relações essenciais e complementares do universo social" (Da Matta 1979:172-173).}

Afirmando que essas duas noçōes básicas são amplamente usadas em todas as sociedades humanas, tendo sido a primeira que põe ênfase no "eu" individualizado e autocontido desenvolvida na tradição ocidental, enquanto a segunda, onde se coloca como dominante a noção de pessoa, cresceu naquelas sociedades de tipo holístico, hierarquizante e tradicional, Da Matta chama a atenção para um ponto fundamental: em todas as sociedades, a despeito da ênfase que coloquem, no todo ou nas partes, ambas as noções estāo sempre presentes, existindo, com efeito, entre elas, uma relaçāo dialética.

Ora, o pajé ou curador característico do meio rural amazônico, em áreas tradicionais, tanto aquela estudada por Galvão (1976), no Baixo Amazonas, como a que venho estudando na microrregião do Salgado, especialmente no interior do município de Vigia, Pará, pode ser considerado como uma personagem do mundo social brasileiro que combinaria em si as duas categorias distintas de indivíduo e pessoa. Daí a dificuldade para entender a categoria pajé e perceber como ela se encaixa num sistema classificatório. No processo de sua formaçāo, desde o momento em que começa a sentir os primeiros sintomas da doença "corrente-do-fundo", até o momento de seu "encruzamento" (quando passa pelo rito de passagem que o transforma em um novo xamã), ele se prepara para colocar seus poderes à disposição da comunidade, construindo o seu caráter de pessoa como membro de um todo social a que deve servir.

Não obstante, esse mesmo pajé também aciona o lado individualizante de seu ethos cultural, pois o processo de assunção ao xamanismo implica, certamente, uma forma de individualização, a partir das crises que o acometem e o fazem fugir do convívio social, buscando os lugares que o aproximam dos "encantados" e da natureza, quando sofre da doença que o leva a se tornar pajé. Ademais, o pajé pode até individualizar-se como feiticeiro, praticando a magia maléfica ("malineza"): receberá sanções negativas, será malvisto, será temido, mas não conheço casos de violência física contra os xamãs, em razão de acusações de feitiçaria.

Mas o que ele não pode fazer é individualizar-se no sentido de dispor de seu dom apenas em benefício próprio, para curar-se dos males físicos e possessōes incontroladas pelos "caruanas", sem usar esse poder em benefício da coletividade. Mesmo que seja um feiticeiro, terá também de ser curador, e nos dois casos estará prestando serviços, para o bem e para o mal. Se, no entanto, tentar fazer como Ramiro e outros que abandonaram ou tentam abandonar o exercício do xamanismo, os próprios "caruanas" se voltam contra ele, aplicando-lhe castigos, o que é uma forma, no contexto das representaçōes locais, de induzi-lo a reassumir seu papel como partícipe do todo social.

Destarte, a ambigüidade da figura do pajé pode ser vista pela sua condição de personagem no qual estariam combinadas, como foi dito, duas categorias distintas $\mathrm{e}$ contraditórias. Num mundo social como o de Itapuá, o mesmo se aplicando a outras comunidades rurais amazônicas, quase nāo há espaço para o indivíduo, no sentido historicamente construído na tradição ocidental. Todos se comportam, ou devem comportar-se, como pessoas, num universo hierarquizado que não se limita apenas a uma comunidade, mas se estende às comunidades vizinhas, às cidades interioranas de maior influência, 
atingindo mesmo a capital do Estado (Belém). A individualização está sujeita a sanções, tanto no plano das relações interpessoais, como no plano do sobrenatural. Um especialista do sagrado, como o pajé, na verdade se individualiza em certos momentos de sua prática social, o que ocorre, de fato, em algumas etapas do processo de assunçāo ao xamanismo, e também durante as sessões de cura, onde ele, ao contrário do que ocorre nos cultos afro-brasileiros, recebe sozinho as entidades de que é instrumento. Mas esta individualização é relativa e passageira, pois só acontece por ser condição necessária para que ele retorne ao mundo social como elo privilegiado da ligação/relação com uma parte do sobrenatural: o mundo "de baixo", o mundo dos "encantados-do-fundo".

Ao contrário do que ocorre no caso da medicina ocidental, forjada dentro da tradição individualizante, a pajelança, como outras medicinas populares da Amazônia e de outras partes do mundo, assume, através dos métodos de tratamento do pajé, um caráter "holístico", totalizante, que também é condizente com a ideologia dos sujeitos populares que a procuram para tratar-se de seus males físicos e tentar resolver seus conflitos psíquicos, assim como seus problemas nas relaçōes interpessoais. 


\section{REFERÊNCIAS BIBLIOGRÁFICAS}

DA MATTA, R. (1979). Carnavais, Malandros e Heróis: para uma sociologia do dilema brasileiro. Rio de Janeiro, Zahar Editores.

DUMONT, L. (1972). Homo Hierarchicus: The caste system and its implications. London Paladin.

FIGUEIREDO, N. (1976). Pajelança e catimb6́ na Região Bragantina. Revista do Instituto Histórico e Geográfico de Alagoas, 32:41-52.

FIGUEIREDO, N. \& A. VERGOLINO E SILVA (1972). Festas de Santos e Encantados. Belém: Academia Paraense de Letras.

GALVÃO, E. (1976). Santos e Visagens: Um estudo da vida religiosa de Itá, Baixo Amazonas. São Paulo, Editora Nacional.

LAPA, J. R. A. (1978). Livro da Visitaçăo do Santo Ofício da Inquisiçāo ao Estado do Grāo-Pará (1763-1769). Texto inédito e apresentação de J. R. Amaral Lapa. Petrópolis, Editora Vozes.

LINS E SILVA, T. (1980). Os Curupiras foram embora: economia, política e ideologia numa comunidade amazônica. Dissertação de mestrado. Rio de Janeiro, Museu Nacional/Universidade Federal do Rio de Janeiro.

MAUÉS, R. H. (1978). A Tensão Constitutiva do Catolicismo: Catolicismo popular e controle eclesiástico. Tese de doutorado. Rio de Janeiro, Museu Nacional/Universidade Federal do Rio de Janeiro.

MAUSS, M. (1974). Uma categoria do espírito humano: A noção de pessoa; a noção do "eu". In: Sociologia e Antropologia, Vol. II. São Paulo, Editora da Universidade de São Paulo.

REMINICK, R. A. (1974). The evil eye belief among the Amhara of Ethiopia. Ethnology 13 (3): 279-291.

SALLES, V. (s.d.). Ritos populares: pajelança e catimbo (mimeo).

—. (1967). Cachaça, pena e maracá. Rio de Janeiro: Brasil açucareiro, 27 (74): 46-55.

SPOONER, B. (1970). The evil eye belief in the Middle East. In: M. DOUGLAS (Ed): Witchcraft

Confessions and Accusations. London: ASA Monographs n 9, p. 311-319. 



\title{
A OUTRA SAÚDE Mental, Psicossocial, Físico Moral?
}

\author{
LLIZ FERNANJO DIAS DUAKTE
}

Da confluência do dualismo entre corpo e mente que caracteriza o desenvolvimento das representações sobre o humano dentro da cultura ocidental moderna, com o fisicalismo hegemônico nos demais saberes científicos, emergiu a noção tão específica de uma doença mental.

A adoção já mais tardia da locução saúde mental representou um momento de insatisfação com alguns pressupostos da primeira noção. Mais recentemente, veio se impondo em alguns meios específicos dos saberes sobre o humano o termo psicossocial, para tentar dar conta e responder a outras ordens de insatisfação com aquela categorização. A antiga tradição médico-filosófica dispunha da expressão físico-moral como qualificação das perturbações que justamente se construíam sobre a articulação entre os dois planos, considerados constitutivos da pessoa.

Ao lidar com representações populares contemporâneas, pareceu-me conveniente reavivar essa referência para dar conta de uma homóloga disposição em lidar com a mediação corpo/alma. Uma querela de categorias é um útil veículo para colocar em questão o estatuto das perturbações e da pessoa na cultura ocidental e rever as possibilidades heurísticas dessa discussão, para a análise da organização do vasto e complexo aparelho institucional armado em torno das terapêuticas psicológicas, psiquiátricas e médico-psiquiátricas.

Ao longo de todo o século XX - mais particularmente após a Segunda Guerra Mundial -, veio se consolidando uma reação ao reducionismo biomédico comprometido com a idéia de 'doença mental', que assumiu as duas formas consieradas 'modernas' de um 'psicologismo' e de um 'sociologismo'.

A primeira forma, instruída a essa altura, sobretudo, pelos desenvolvimentos da Psicanálise, assume a realidade de um patamar específico da realidade humana que não se confunde com a corporalidade estrita e ocupa - por assim dizer - o lugar antigo da alma.

* Trabalho apresentado originalmente como comunicação à Mesa sobre "Antropologia e Saúde Utbana" do I Encontro Nacional de Antropologia Médica, Salvador (BA), três a seis de novembro de 1993. 
Esse pressuposto ontologico impõe uma nova representação da causalidade e dinâmica das perturbações - agora nomeadas 'psíquicas', 'psicológicas', 'inconscientes', etc. A segunda forma, nutrida da crítica social decorrente da crescente consciência das contradições e malignas características do desenvolvimento do industrialismo, do capitalismo ou do que se chama tão freqüentemente de 'modernidade', procura subordinar a compreensão das perturbaçōes à percepção do condicionamento 'social' a que estão sujeitas todas as experiências pessoais humanas. Mais recentemente, concertaram-se essas duas perspectivas na proposição de uma locução de luta contra o reducionismo biomédico: distúrbio ou aflição 'psicossocial' (em inglês, o psychosocial distress).

Compreende-se sob tal rubrica a ação concomitante dos condicionamentos sociais e de uma dinâmica propriamente psicológica. São dois, sobretudo, os eixos sobre o que se articula esse novo modo de representação das perturbaçōes prevalecentes no mundo urbano das sociedades modernas. Chamei-lhes reducionismos 'do poder/dominação' e do 'gênero', ao examinar a literatura da Antropologia Médica norte-americana a respeito de uma manifestação importante de perturbações: os 'nervos'.

Foi justamente a propósito dos 'nervos', enquanto código de expressão privilegiado das perturbaçōes das classes populares brasileiras, que me pareceu necessário reavivar a velha locução fisico-moral aplicada às perturbações. Efetivamente, a qualidade 'físicomoral' evoca a necessária e entranhada imbricação, correlação entre o nível físico, corporal, da experiência humana e tudo aquilo que, de outra parte, se lhe opõe - e se nomeia e concebe de forma tão díspar entre as culturas humanas (como na nossa tradição, o antigo 'espiritual' e o recente 'psíquico'). $O$ retorno a uma categoria tradicional teria neste caso a vantagem heurística fundamental de relativizar, de não endossar a priori as representações modernas - que sustentam nosso senso comum acadêmico. Seria, nesse caso, mais propícia a encaminhar o reconhecimento das condições fundamentalmente simbolicas, culturais, da experiência humana. Os próprios conceitos de 'doença mental' e de 'distúrbio psicossocial' seriam, assim, casos culturalmente específicos do conjunto mais amplo das 'perturbações físico-morais', por expressarem modos de sentido próprios de nossa cultura.

A Antropologia Médica de tipo norte-americano devota uma justificada atenção à maneira como a representação do nervoso desafia o dualismo fundamental das concepções ocidentais modernas sobre a pessoa. Setha Low já afirmava em 1985: "ele sempre apresenta a propriedade especial de ser um sintoma sem a dicotomia entre mente (mind) e corpo" (Low, 1985:189), inaugurando, assim, provavelmente uma longa série de interpretações que postulam a inexistência da dicotomia nas formas etnográficas do fenômeno do nervoso. Como é inevitável em nossa cultura, a categoria inglesa habitual de mind tem uma extensão semântica mais complexa que a de body/corpo (a que correspondem os adjetivos sinônimos físico, somático e organico). A maneira como se referem a mind alguns dos trabalhos estudados revela que lhe estão associados os "sentimentos" e as "emoções" e que o seu adjetivo correlato não é "mental" ou "moral", mas "psíquir,o" ou "psicol6gico": "Ao rejeitar a dualidade mente/corpo da biomedicina, nervios expressa ao mesmo tempo a dor física e psíquica" (Guarnaccia, et al., 1988:1229). Na verdade, a força da psicologização impõe inclusive que uma das referências à dicotomia seja feita sob a forma clássica do "soma"/"psyche", hoje associada tão caracteristicamente ao modelo psicanalítico. 
Minha própria hipotese a respeito privilegiava, pelo contrário, o caráter mediador de todo esse conjunto semântico, de fio de relação entre o físico e o moral (Duarte, 1986a: Cap.V.d) - tão radicalmente separados e estanquizados na tradição cartesiana. Pois, com efeito, os nervos não abolem o dualismo físico-moral, mas constituem antes uma verdadeira teoria das conexões e fluxos possíveis entre as duas dimensões, tal como foram anteriormente no Ocidente o sistema clássico dos humores ou dos temperamentos (Pigeaud, 1981: 125) e o sistema da degenerescência, ele mesmo já articulado a partir da configuração do nervoso (Duarte, 1988). Compreende-se assim que - como testemunham todas as etnografias - seja possível, segundo a lógica do nervoso, que um evento físico possa acarretar reações morais ou uma experiência moral ter implicaçōes físicas; sem que, no entanto, se deixe de distinguir entre os dois planos.

Uma implicação muito importante dessa qualidade eminentemente relacional dos nervos é a de compor uma teoria não-psicologizada do humano. Os nervos são pensados como um meio físico de experiências tanto físicas quanto morais - em perfeita oposição à idéia do psiquismo, concebido para se substituir ao antigo nível moral e estabelecer sobre o físico uma nova hegemonia. Os nervos são uma típica representação relacional da pessoa, enquanto o psiquismo é uma representação individualizada, associável às marcas ideológicas mais amplas da modernidade ocidental. Nãoé surpreendente portanto que a literatura confirme a radical diferença que opõe dentro mesmo dos E.U.A. a representação da pessoa dos segmentos sociais mais afinados com a dimensão moderna da Grande Tradição ocidental (individualizada e psicologizada) e a daqueles outros que, por muitos motivos, continuam a expressar a antiga ordem relacional (Kay et al., 1989:281 e 287; Jenkin, 1988:1237 e 1240; Guarnaccia et al., 1992:194).

É significativo o uso feito pela Antropologia Médica (sobretudo norte-americana) da categoria psicossocial para tentar cobrir o abismo entre o nível do indivíduo (representado como 'psicológico') e o das relaçōes (resumidas, neste caso, na idéia do 'social'). Os nervos e tudo o que lhes diz respeito são porém inconvenientemente descritos enquanto um fenômeno "psicossocial", por expressarem justamente uma visão de mundo não-individualizada e não-psicologizada. Repetir-se-ia aqui o embaraço antes analisado do uso de categorias psicopatológicas para compreender as perturbações nervosas.

$O$ fenômeno dos nervos (enquanto modo cultural de reconhecer perturbações fisico-morais) é privilegiado para compreender as questōes centrais da definição da cultura ocidental moderna e seus limites e descontinuidades. A noção de pessoa específica da configuração ideologica a que se tem chamado de 'individualismo' atravessa todo o horizonte cosmol6gico em que se tem movido essa cultura (e todos os saberes que lhe são associados, como a Medicina ou a Antropologia). Os nervos dificilmente poderiam ser compreendidos a partir de uma estratégia puramente empirista, que fosse apenas superpondo dados etnográficos locais; descomprometidos com uma teoria mais ampla a respeito da mudança e da diferenciação cultural dentro das sociedades afetadas pela modernização individualista.

Parece haver uma certa correlação entre a utilização plena do código do nervoso e um modo cultural associado à relacionalidade, à complementaridade e à hierarquia. O modo que se lhe opõe - mutualista, singularizante e individualizante - expressa-se de modo privilegiado através das representações psicologizadas da pessoa, seja sob as formas 
biomedicalizantes da psiquiatria (associadas nesse caso a uma ênfase mais linear na ideologia da vontade individual), seja sob as formas simbolizantes da psicanálise (mediadas pela representação de um inconsciente individual).

Essa proposta analítica $\boldsymbol{E}$ antropologica por excelência, na medida em que se quer comparativa e relativista. Sua formulaçăo depende de um radical estranhamento em relação aos valores centrais da versão 'moderna' de nossa cultura, retendo de certa forma apenas a disposição universalista (que, embora também culturalmente específica, é a garantia da manutenção da empresa antropológica). Ela exige, porém, redobrados cuidados no trato com os dados concretos. A complexidade das sociedades ocidentais modernas se arma sobre uma multiplicidade de eixos, ora permitindo aparentes convivências de planos simbólicos muito distintos, ora sugerindo a dissociaçāo entre outros tantos essencialmente homólogos.

A dicotomia entre hierarquia (ou holismo, nos termos de Dumont) e individualismo pode fazer sentido entre teorias eruditas ou populares da pessoa (como são o nervoso e o psicologismo), mas pode também fazer sentido entre culturas nacionais, entre culturas de classe, entre experiências de gênero ou entre diferentes momentos da história da cultura ocidental. É do difícil cruzamento de muitas dessas linhas de interpretação que se pode obter eventualmente algum efeito heurístico que escape ao senso comum.

A leitura médico-antropológica do nervoso traz à discussão todo um tesouro de informação etnográfica. As grandes teorias que se propōem organizá-lo são: uma teoria biomédica que vê nesses fenômenos a mera expressão da doença orgânica (mesmo que sob a forma psiquiátrica da doença mental); uma teoria psicologizante que os vê como expressão do funcionamento das emoçōes e do psiquismo individual e que permanece sempre apenas em estado virtual, por não poder esquecer a dimensão social de seus objetos (donde a necessidade da locução "psicossocial"); uma teoria sociologica que os encara como expressão ou reflexo da realidade última do conflito de classe ou de gênero e da dominaçāo daí decorrente (assim como das perversas condições de reproduçāo social que lhe poderiam ser atribuídas) e que não dispöe de recursos, portanto, para lidar com a especificidade desse código (por oposiçāo a tantos outros que falam de sofrimento e perturbação em situações de diferença social). Nenhuma dessas teorias trata da diferenciação cultural em si. Esta se impõe através dos dados etnográficos, que nos aportam ao mesmo tempo uma surpreendente extensão da pertinência do código do nervoso (entre grupos, países e continentes) e uma nāo menos surpreendente e concomitante descontinuidade no seu uso ou legitimidade (dentro de grupos, países ou continentes). $O$ que faz afinal com que haja algo em comum entre o conjunto das classes populares latino-americanas, migrantes porto-riquenhos e gregos nos E.U.A., trabalhadores urbanos baladi no Cairo, pobres habitantes do Kentucky ou de uma aldeia da Terra Nova, as elites européias do Séc. $\mathrm{XIX} \mathrm{e}$ as elites contemporâneas do Sul dos E.U.A. ?

A percepçăo de que o código do nervoso é solidário de uma verdadeira e integrada representação da pessoa (físico-moral) e que esta, por sua vez, só pode existir dentro de uma configuraçāo cultural específica tem que passar em primeiro lugar pela superaçāo da confusão entre sua condição de código cultural e o eventual reconhecimento da existência de nervos no corpo humano. Se esse código năo poderia prescindir da antecedência histórica e lógica do saber fisiológico sobre o sistema nervoso desencadeado entre os Sécs. 
XVII e XVIII, ele quase nada mais the deve em suas formas contemporâneas. Procedimento homólogo seria necessário para evitar a confusão entre a representação do 'psicológico' e o reconhecimento da existência de emoções e sentimentos que se desencadeiam no plano pessoal (se não necessariamente 'individual') e sobre as quais se puderam ancorar neste último século inúmeras teorias.

Trata-se em seguida de admitir que existe realmente uma 'cultura ocidental' e que ela tem a sua história marcada pelo desenvolvimento e crescente hegemonização da ideologia ou configuração ideológica do 'individualismo' (apesar de abarcar uma miríade de segmentações culturais em outros níveis, recortadas segundo diferentes eixos). Essa hipótese permite observar sob nova luz a evolução das teorias sobre a pessoa desde a Antiguidade Clássica e particularmente as representações sobre os nervos, tão facilmente redutíveis a um fio linear de progresso. Os saberes antigos dos nervos nunca constituíram a base de uma teoria da pessoa (Solmsen, 1961; Pigeaud, 1981 e Lain-Entralgo, 1972). Eles contribuiram para as especulações correntes sobre a constituição humana, tais como as teorias sobre a relação entre o coração e o cérebro (e os pneuma), mas mantiveram-se subordinados às teorias da alma e à configuração dos humores e temperamentos até o Séc. XVIII. É só então, no bojo das grandes transformações culturais e sociais que dão nascimento à versão dita 'moderna' da cultura ocidental, que os nervos são reapropriados num sistema mecanicista integrado (justamente o 'sistema nervoso'), servindo de suporte para um novo sujeito representado como imanente, autônomo e universalmente idêntico, capaz de suportar os nascentes ideais da 'liberdade' e da 'igualdade' ( Foucault, 1978: Cap. 8 e 9; Gauchet \& Swain, 1980; Duarte, 1986a: Cap.III.b). Sabe-se, porém, qual foi o destino dessa representação ao longo de todo o Séc. XIX: servir à paulatina reconstituição de uma configuração de diferenças, relacional, hieráqquica, que culminou nos modelos da degenerescência e da neurastenia. São estas formas derivadas do saber fisiológico setecentista e reconvertidas a uma lógica hierárquica que os movimentos médico-higienistas fazem passar a todas as populaçōes afetadas pela cultura ocidental. Pelo final do Séc. XIX, a força das idéias individualizantes impōe o surgimento de uma nova configuração da pessoa, a dos saberes psicologizados (sobretudo a partir da influência da Psicanálise e em oposição ao saber considerado antiquado dos nervos). As classes populares em geral, no Ocidente, e eventualmente os segmentos periféricos ou 'atrasados' das elites continuaram porém - e continuam até hoje - a dispor de um modelo de pessoa condizente ou solidário com suas próprias resistências à individualização (no sentido de conversão à ideologia 'culta' do individualismo).

Não é portanto - por exemplo - por participarem de uma cultura 'latina' (ou hispano-americana) que os "Mexican Americans" ou os migrantes porto-riquenhos ou salvadorenhos nos E.U.A. representam suas perturbações físico-morais através do código do nervoso. Não é tampouco por participarem de uma cultura circum-mediterrânea que os aldeōes gregos ou os trabalhadores cairotas também pensam sofrer através de seus nervos (Clark, 1989; Krieger, 1989). Nem é ainda - como bem criticou Van Schaik (1989) - por participarem de uma 'cultura da pobreza' que os mineiros dos Apalaches falam dos nervos ao expressar seu distress. Eles têm em comum com muitos outros grupos sociais contemporâneos ou oitocentistas sua não-individualização pela psicologização, por oposição aos "Anglo Americans" da análise de Jenkins (1988), às viúvas "Mexican American" 'mais 
aculturadas' da análise de Kay \& Portillo (1989), à institutrice psicanalizada paciente de Lagadec (1985) ou aos membros em geral das classes letradas de Boston, de San José da Costa Rica, do Rio de Janeiro ou de Atenas.

A apropriação do fenômeno do nervoso por essa via analítica também permite compreender que os explorados e famintos habitantes do Nordeste brasileiro descritos por Scheper-Hughes (Scheper-Hughes, 1988; Scheper-Hughes, 1992) possam expressar sua perturbação num código que serviu à manifestação de outras perturbaçōes entre os personagens de Jane Austen (Davis \& Whitten, 1988) ou os de Marcel Proust (Duarte, 1990). A própria oposição entre cultura laica X cultura profissional, tematizada por vários autores, ganha novos contornos desde que se compreenda que o nervoso não é $a$ cultura laica, mas uma das culturas laicas possíveis (como há hoje também uma psicologizada e houve certamente outrora uma outra humoral) que se enfrentam com uma cultura profissional quase completamente afastada do modelo nervoso e comprometida com alguma das versōes do saber psicologizado contemporâneo sobre a pessoa. A compreensāo dos embaraços (e perturbações) decorrentes desse descompasso entre teorias da perturbaçăo no confronto entre terapeuta e paciente (mas também, em alguns casos, entre agentes religiosos e fiéis, demandando respostas à aflição) é sem dúvida uma das frentes de pesquisa mais urgentes e sérias. Alguns dos trabalhos resenhados apresentam referências etnográficas interessantes a esse respeito. sem que possam efetivamente ultrapassar o nível da mera constatação ou registro da descontinuidade cultural.

Esta perspectiva analítica não desqualifica a importância do conhecimento sobre as condições sociais e culturais associáveis à expropriação e fome dos trabalhadores do Nordeste brasileiro, à desvairada violência que cerca os moradores pobres de Belfast (Sluka, 1989) ou às eventuais perversões dos modelos hierárquicos de relação entre os gêneros, entre etnias ou entre classes. Pondera apenas que o modelo do nervoso é algo de mais abrangente e mais complexo do que sua utilização nesses contextos dramáticos e que maiores vantagens críticas decorreriam da dissociação metodológica entre esses objetos de conhecimento do que de sua agregação descontrolada. A literatura médico-antropológica, ao recusar com justiça o determinismo biomédico, opera com a hipótese de uma correlação entre 'condiçōes de vida' (ou sociais, ou socioeconômicas), 'perturbações' (distress, sofrimento, aflição, etc.) e 'nervoso'.

Reitero, nesse sentido, a necessidade de distinguir analiticamente os dois níveis de intersecção entre as três dimensões: num primeiro plano, apresentam-se à pesquisa as relações entre as 'condições de vida' e o eventual desencadeamento de 'perturbações'; num segundo, as relaçōes entre a existência de perturbações e a eventual utilização do código do 'nervoso'. Desse segundo nível as 'condições de vida' não estarão ausentes; mas estarão aí mediadas ou traduzidas pelo código cultural mais amplo que - ao Ihes atribuir um sentido diferenciado, ainda que negativo - fez de sua vida bruta fatos humanos. É na direção dessa compreensão ampliada que a proposta de lidar com esses fenômenos pela via das 'perturbações físico-morais' faz o seu sentido, aqui defendido. 


\section{REFERÊNCIAS BIBLIOGRÁFICAS}

CLARK. M. H. (1989). Nevra in a Greek village: idiom, methaphor, symptom, or disorder ? In D. L. Davis, \& S. M. Low (Ed.), Gender, health and illness. The case of nerves. New York: Hemisphere Publishing Corporation. p. 103-126.

DAVIS, D. L., \& WHITTEN, R. (1988). Medical and popular traditions of nerves. Social Science \& Medicine, 26(12), 1209-1222.

DUARTE, L. F. (1986a), Da Vida Nervosa (nas classes trabalhadoras urbanas). Rio de Janeiro: Jorge Zahar Editor/CNPq.

- (1988). A Psychopathia Sexualis de Krafft-Ebing. ou o progresso moral pela ciência das perversões. Cadernos do Instituto de Medicina Social, 2 (3/agosto-setembro), p. $9-40$.

- (1990). A representaçăo do nervoso na cultura literária e sociológica do século XIX e começo do século XX. Anuário Antropológico 87 (pp. 93-116). Rio de Janeiro: Ed. UnB/Tempo Brasileiro.

FOUCAULT, M. (1978). História da Loucura na Idade Clássica. Săo Paulo: Perspectiva.

GAUCHET, M.. \& SWAIN, G. (1980). La pratique de l'esprit humain (l'institution asilaire et la révolution démocratique). Paris: Gallimard.

GUARNACCIA, P. \& FARIAS. P. (1988). The social meaning of nervios : a case study of a Central American woman. Social Science \& Medicine, 26(12), p 1223-1231.

GUARNACCIA, P. J., PARRA, P., DESCHAMPS, A., MILSTEIN, G., \& ARGILES, N. (1992). Si Dios Quiere: Hispanic families' experiences of caring for a seriously mentally ill family member. Culture, Medicine and Psychiatry, 16, 187-215.

JENKINS, J. (1988). Conceptions of schizophrenia as a problem of nerves : a cross-cultural comparison of Mexican-Americans and Anglo-Americans. Social Science \& Medicine, 26(12), p.1233-1243.

KAY, M., \& PORTILLO, C. (1989). Nervios and dysphoria in Mexican American widows. In D. L. DAVIS, \& S. M. LOW (Ed.), Gender, health and illness. The case of nerves. New York: Hemisphere Publishing Corporation, p. 181-202.

KRIEGER, L. (1989). Nerves and psychosomatic illness: the case of Um Ramadan. In D. L. Davis, \& S. M. Low (Ed.), Gender, health and illness. The case of nerves. New York: Hemisphere Publishing Corporation., p. 89-102.

LAGADEC, G. (1985). Discours des malades. Esquisse d'une théorie des conceptions populaires de la physiopathologie. Bulletin d'Ethnomédecine, 33(1er. trim.), p. 3-26.

LAIN-ENTRALGO, P. (1972). História universal de la medicina , Barcelona: Salvat.

LOW, S. M. (1985). Culturally interpreted symptoms of culture-bound syndromes: a cross-cultural review of nerves. Social Science \& Medicine, 2I(187), p. 187-196.

PIGEAUD. J. (1981), La maladie de l'âme: étude sur la relation de l'âme e du corps dans la tradition médico-philosophique antique. Paris: Société d'Edition les Belles Lettres. 
SCHEPER-HUGHES, N. (1988). The Madness of Hunger: Sickness, Delirium, and Human Needs. Culture , Medicine and Psychiarry, 12(4), p. 429-458.

-. (1992). Death without weeping. The violence of every day life in Brazil. Berkeley: University of California Press.

SLUKA, J. A. (1989). Living on their nerves: nervous debility in Northern Ireland. In D. L. Davis, \& S. M. Low (Ed.), Gender, health and illness. The case of nerves. New York: Hemisphere Publishing Corporation, p. 127-151.

SOLMSEN, F. (1961). Greek philosophy and the discovery of the nerves. Museum Helvelicum, 18(4), p. $150-197$.

VAN SCHAIK, E. (1989). Paradigms underlying the study of nerves as a popular illness term in Eastern Kentucky. Medical Anthropology, //(1), 15-28. 


\title{
O DISCURSO SOBRE A ENFERMIDADE MENTAL ${ }^{*}$
}

\author{
Paljo CÉsar AJ.ves
}

\begin{abstract}
"L'humanisme d'aujourd'hui n'a plus rien de décoratifni de bienséant (...) Il ne parle plus de l'homme et de l'esprit que sobrement, avec pudeur; l'esprit et l'homme ne sont jamais, ils transparaissent dans le mouvement par lequel le corps se fait geste, le langage oeuvre, la coexistence vérité" (MerleauPonty)
\end{abstract}

\section{INTRODUÇÃO}

Nos últimos anos intensificaram-se no Brasil os movimentos em favor da descentralização. No que diz respeito à política de saúde mental, a idéia de descentralização está associada a uma reorganização da rede assistencial em saúde, com a extinção progressiva dos hospitais psiquiátricos (genericamente denominados de manicômios). Um aspecto fundamental subjacente a esse projeto é a concepção de uma nova prática assistencial não mais centralizada no objeto doença mental, mas no objeto existência-sofrimento em sua relação com a reprodução sociocultural das pessoas (Pelbart, 1990). Esta reforma pressupõe uma maior sensibilidade dos programas de saúde mental aos valores e crenças das comunidades-alvo, bem como um constante diálogo entre serviços e comunidade. Faz-se necessário um conhecimento mais específico dos processos pelos quais os diversos grupos sociais atribuem valores e constroem significados e práticas relativas à saúde e à enfermidade. Aqui talvez esteja a contribuição que a antropologia pode dar ao desenvolvimento

\footnotetext{
* Trabalho apresentado no I Encontro Nacional de Antropologia Médica, realizado em Salvador (BA) no
} período de três a seis de novembro de 1993. 
de serviços de saúde mental mais sensiveis às realidades culturais e sociais específicas dos seus usuários e abertos ao envolvimento e participaçāo destes na provisão da saúde.

Uma das principais áreas da Antropologia Médica - a Etnopsiquiatria - procura justamente examinar o papel da cultura na construção da etiologia, expressão, curso e tratamento do problema mental. A idéia de que cultura está relacionada com a desordem mental é parte do legado de Jean-Jacques Rousseau. Contudo, o estudo propriamente antropológico dessa questão é bem mais recente. Foi no início da década de 1960 que pesquisadores como Raymond Price (1960), Jerome Frank (1961), Devereux (1961) e Ari Kiev (1964) determinaram uma das premissas básicas para os estudos etnopsiquiátricos posteriores - a de que é através das descobertas e descrições das construções culturais que podemos compreender os processos cognitivos e sociais que organizam as interpretações e respostas para os eventos de enfermidade.

Tal premissa merece algumas consideraçōes. Uma questāo crucial a ser colocada é a de como pensar a natureza das crenças e valores relacionados ao problema mental, a de como é que elas aparecem dentro de contextos sociais específicos.

De uma maneira geral, o locus de observação da Etnopsiquiatria tem estado dirigido para as estruturas cognitivas subjacentes à construção de significados do problema mental. Essas estruturas são vistas como detendo uma racionalidade intrínseca, que se expressa em uma lógica consistente ou coerente de crenças e ações. Nessa perspectiva, a Etnopsiquiatria, ao assumir o pressuposto de que as pessoas agem a partir de modelos culturais pré-determinados e falam racionalmente sobre suas crenças e valores, tende a reduzir a diversidade da conduta humana a uma questāo de "formas". A retórica da racionalidade é uma preocupação constante da cultura ocidental e está presente tanto nos estudos antropológicos como nas diversas práticas psicoterapêuticas.

A ênfase na questão cognitiva deriva-se, em grande parte, do fato de que muitos dos estudos etnopsiquiátricos foram desenvolvidos com/e em agências terapêuticas. Essas agências constituem tipos de instituiçōes sociais. Conforme define Berger (1973), instituições são tipificações recíprocas de ações habituais desenvolvidas por determinados tipos de atores. Enquanto tipificaçōes, as agências terapêuticas não só implicam um corpo de conhecimento válido, constituído em códigos ou "jogos" de linguagem, sobre os processos de diagnóstico e tratamento, como também controlam os indivíduos ao estabelecer padrões previamente definidos de conduta. Qualquer agência terapêutica, ao definir áreas institucionalizadas de conduta, designa todas as situaçôes que se localizam dentro destas áreas. Logo, é de se esperar que nas instituições de cura as imagens convencionais que os agentes terapêuticos têm do paciente reflitam apenas as experiências de enfermidade que possam se adequar às estruturas cognitivas (estereótipos) pertinentes a estas instituiçōes. Isso significa dizer que qualquer agência terapêutica reduz a diversidade de experiências sociais a um dado conjunto de modelo.

Enquanto presa à retórica da racionalidade, a Etnopsiquiatria tende a menosprezar tanto as bases sociais como aspectos irracionais das crenças e valores médicos. Isso não significa dizer que negue a existência dessas realidades. A irracionalidade é usualmente vista como comportamento desviante ou categoria residual, e as relações sociais são analisadas como reprodutoras de padrōes culturais pré-estabelecidos. Nessa perspectiva, podemos correr o rísco de não perceber que o conhecimento médico do leigo é situacional 
e muitas vezes inconsistente e incoerente em referência a determinadoos modelos culturais (Young, 1982). É importante que levemos em consideração que as crenças são produtos de ações humanas concretas e servem para justificar determinadas atitudes. Esse fato torna-se mais óbvio quando nos movemos da ótica institucional para a análise de indivíduos e grupos sociais contextualizados no mundo da vida cotidiana.

Não será, portanto, pela simples decodificação de modelos cognitivos presentes em uma dada cultura que poderemos adequadamente compreender os processos pelos quais os indivíduos e grupos sociais estabelecem significados para sua conduta. É de se esperar que em episódios aflitivos as pessoas desenvolvam múltiplas interpretaçōes sobre a enfermidade. Reduzir esses discursos a estruturas cognitivas-racionais é deixar de lado aspectos fundamentais da conduta humana. Enquanto preso ao estudo do mundo social através de um quadro objetivo de referência, o observador científico pouco tem a nos dizer sobre o processo de idealização e formalização em si, sobre a gênese do significado que os fenômenos sociais adquirem para os atores.

O presente trabalho objetiva contribuir com a análise dessa questão. Procuramos, através de um estudo de caso, compreender como, e em que contexto, as pessoas formulam determinados discursos relativos ao problema mental. Mais especificamente, examinaremos um conjunto de narrações elaboradas por Neuza, moradora do Nordeste de Amaralina, bairro popular de Salvador, sobre a experiência de enfermidade da sua filha Mazinha. $O$ caso aqui escolhido foi acompanhado por um período de aproximadamente nove meses, com visitas constantes à família.

\section{CONTEXTO DO ESTUDO}

Este trabalho é o resultado parcial de uma pesquisa mais ampla, de base etnográfica, desenvolvida entre abril de 1991 a março de 1993, financiado pelo convênio OPAS-CNPq. O objetivo principal da pesquisa foi investigar as concep̧̧ōes populares de doença mental, os comportamentos e símbolos que as sustentam e, principalmente, as diferentes formas utilizadas para lidar com situações concretas de doença mental. Além de diversos tipos de agentes terapêuticos, foram entrevistados mais de 60 informantes-chave e, dentre eles, 30 foram selecionados para observação sistemática (durante aproximadamente um ano) acompanhada de entrevistas mais aprofundadas. $O$ trabalho de campo foi desenvolvido no Nordeste de Amaralina.

O Nordeste de Amaralina (250 hectares), de acordo com o censo demográfico de 1980, tinha uma população de aproximadamente 80 mil pessoas que habitavam em menos de 14 mil residências. Apenas $11,3 \%$ da população acima de 15 anos possuía educação primária completa e $60 \%$ era de migrantes rurais. Esse bairro tem se destacado na imprensa pelo alto índice de violência. 


\section{O DISCURSO DE NEUZA}

Neuza nasceu em Caldas de Cipó no ano de 1950. Aos treze anos, veio morar em Salvador, arranjando trabalho como empregada doméstica. Casou-se com dezessete anos e teve sete filhos (dois morreram). Reside no Nordeste há vinte e três anos; partilha sua pequena casa (dois quartos, uma sala e cozinha) com a família, composta por oito pessoas. Neuza $\in$ analfabeta e trabalha como lavadeira.

Mazinha, 16 anos, é a segunda filha de Neuza. No dizer da māe, "nunca tinha ocupado médico" até abril de 1991. Conforme relato de Neuza; foi em novembro de 1990 que ela começou a observar que Mazinha estava ficando muito irritada devido à sua reduzida capacidade de preensão com a mão direita: tudo que pegava, derrubava. No início, o caso foi tomado como brincadeira e a mãe acreditava que com algumas surras resolveria o desleixo da filha. Com o passar do tempo, Mazinha piorou. Ela passou a responder quando Neuza reclamava. "Assim, quando eu queria bater nela, ela me xingava e queria enfrentar assim, coisas que meus filhos nunca fizeram". Essa atitude de Mazinha fez com que Neuza começasse a observar que a filha estava com algum problema. Além do mais, ela queixava-se constantemente de fortes dores de cabeça, reagia excessivamente a pequenos aborrecimentos e contratempos, desenvolvendo uma conduta desconfiada perante os outros, agredia constantemente os irmãos e ficava muito agitada durante a noite. "Ela saltava daquela cama para aquela outra, para uma outra, a noite toda. Pegava a roupa dela $e$ descosturava tudinho. Chegava de noite e ficava assim (...) ela pegava a roupa e a presilha e ficava desmanchando as costuras da roupa".

Foi em um domingo de abril de 1991, quando começávamos o trabalho de campo no Nordeste de Amaralina, que Neuza se deu conta da gravidade do problema. Mazinha tinha ameaçado a irmã mais velha com uma faca e se não fosse a intervenção da vizinha a situação teria chegado às vias de fato. Decididamente a filha estava enferma. "Ah, ai eu fui num médico sem ela. Um médico que tinha de cabeça ali. (...) O médico disse: 'Ela tem problema de dor de cabeça ?' Eu disse: 'tem bastante'. O médico disse: 'Ela tem problema de vista'. Aí me deu um papelzinho pra eu levar ela num médico de vista. Eu levei (...) Aí fez um exame e tudo, passou óculo, eu comprei, demorei pra comprar. E ela assim, ela assim... Continuava do mesmo jeito. Do mesmo jeito derramando tudo". Após ter adquirido os 6́culos, Neuza retornou ao médico. "Aí eu disse ao doutor: Será que ela não tem um problema de cabeça? Ele disse: 'Não.' (...) Ai eu não fui mais lá".

Para Neuza, a filha não tinha apenas um problema físico que pudesse ser tratado pelo médico: tinha algo mais e precisava ser benzida. Assim, Neuza procurou uma ex-patroa, rezadeira (provavelmente espírita), que se ofereceu para ficar com Mazinha. A menina passou alguns dias na casa da patroa. "Com oito dias certinho ela veio embora. Mas com o mesmo problema (...) Ela ficava assim, tinha que contar esses cinco dedos não sei quantas vezes (...) Eu já tava com medo dela morrer, que ela näo queria mais nem tomar banho".

Nessa época, a cunhada de Neuza estava se recuperando de alcoolismo por um tratamento indicado por Seu Dedéu, um pai-de-santo. Esta cunhada convenceu Neuza de que o caso de Mazinha era problema para curador. Neuza, então, resolveu procurar ajuda no terreiro de Dedéu. O pai de Mazinha, porteiro de ediff́cio, mesmo relutante em aceitar 
que a filha estivesse enferma - para ele o problema não passava de "nervo fraco" que melhoraria com a idade - terminou por levá-la, acompanhado da esposa e da irmã, à casa do pai-de-santo. Na descriçāo da mãe, a filha "se lascou todinha na casa do homem. Vesti um bermudão nela azul que ela tem. Não tinha quem segurasse. (...) Ela assim, bi, puxando a roupa, querendo sair. $O$ homem falava os negócio la, falava os guia do homem $e$ ela botava a cara lá em cima. Uma confusão. Eu não sei se era ela ou era o pertubado que já tava nela. Sei lá! (...) Aí eu prendi a mão dela e tudo, ai ele veio rezou nela e tudo, foi que ela acalmou". Dedéu confirmou as suspeitas de Neuza: Mazinha tinha problema de "encosto", tinha sido vítima de feitiçaria. Conforme Neuza, "Seu Dedéu disse que botaram um negócio que não foi para ela. Ela estava incomodada e pisou com o pé direito e atingiu o lado direito todo". O caso requeria um "trabalho".

Neuza e sua filha voltaram para casa aparentemente mais calmas. Mas, a partir desse dia, a relação entre mãe e filha, que já vinha se deteriorando nos últimos meses, aguçou-se. Diz Neuza: "Ela só não encarava eu. Parecia que tinha sido eu que tinha botado a doença em cima dela. Ela conversava com o pai, tudo direitinho, mas comigo era uma raiva que ela tinha de mim!' Parece que ela dizia que eu não dava a saúde dela porque eu nāo queria".

O tratamento prescrito por Dedéu consistia no uso de vitaminas e banhos e na realizaçāo de um "trabalho". Neuza forneceria os mantimentos necessários para que Dedéu preparasse um despacho a ser depositado em uma encruzilhada. Feito o despacho, Mazinha deveria voltar ao terreiro. Conforme Neuza, foi para "passar uma parafina no corpo dela. Passou bem no braço todo. Quando saiu um negócio do corpo, Mazinha me deu um tapa (...) Foi o pertubado que tava nela (...) Depois ficou calma. Nāo teve mais nada, pouquinho o negócio da mão. A mão já não fechava toda hora assim". Neuza parecia satisfeita com o tratamento de Dedéu.

Depois dessa segunda visita ao terreiro, Mazinha parou com o tratamento do pai de santo. Ela tinha feito amizade com uma freqüentadora da Igreja Universal. Incentivada pelo pai, Mazinha assistiu a alguns cultos pentecostais. Porém, poucos dias depois, abandonou o culto e as amigas relacionadas à Igreja Universal. Explica Neuza que o pastor pedia a todos os fiéis que fechassem os olhos. "Ela disse que fechava, aí, dai a pouco abria e ela pelejava pra cair e não caía. É sinal que ela não tem nada, porcaria nenhuma. Ela disse que a menina da comadre Hilda caiu e ela nāo caiu. Eu disse: 'Porque não foi o seu dia'. Ela disse: 'Ah, pois eu vou pra vê se eu caio'. Tornou ir uns três dias e não caiu. Aí ela disse: 'Agora eu não vou mais porque eu não tenho nada."

Nesse ínterim, nāo convencendo a filha a retornar com o tratamento de Dedéu, Neuza procura nova ajuda. Através de algumas amigas, Neuza é indicada a uma rezadeira. Uma outra explicação é dada para o caso de Mazinha. Conforme a rezadeira, o problema de Mazinha foi causado pela quebra de uma promessa. Neuza, apos ter perdido uma criança, prometeu oferecer um caruru a São Cosme se tivesse outro filho. Nasceu Mazinha e a obrigação não foi paga. Na consulta com a rezadeira, Neuza lembrou-se de que a filha "nasceu toda cheia de negócio torrenco" e que, estranhamente, falou aos seis meses de idade. Neuza teria agora que pagar a promessa. O caruru foi marcado para os meados de setembro e outra vez não foi realizadó. "Aí passou oito dias que eu não dei o caruru e ela apresentou novamente o problema da mão. Qualquer rebordada aconteceu. Adoeceu todo mundo aqui dentro de casa. Essa menina quase morre com uma febre assim uma dor de cabeça. Aquele 
minininho meu teve ruím que levaram nas carreiras para o Semec". A propria Neuza ficou acamada por quatro dias.

Nas nossas últimas conversas com Neuza, ela acreditava que a filha tinha melhorado um pouco mas o problema da mão continuava. "Eu achei que ela melhorou. Não sei nem o que foi que melhorou ela, se foi a Igreja, se foi a casa de Seu Dedéu, se foi a reza da mulher. Eu não sei nem o que foi". Neuza ainda procurava uma resposta definitiva para o problema da filha. A conselho de uma irmā, ela estava pensando em buscar tratamento com um médico espírita que atendia no bairro.

\section{CONSIDERAÇÕES SOBRE O DISCURSO DE NEUZA}

Procurei desenvolver o relato de Neuza com certos detalhes, pois ele revela, de forma ilustrativa, alguns traços básicos sobre o processo pelo qual os indivíduos constroem uma rede de explicações para a doença. $O$ ponto fundamental que trago à discussão diz respeito à questāo da experiência da enfermidade (Alves, 1993).

Para compreendermos essa "experiência" partiremos da premissa de que a idéia de enfermidade está necessariamente presa a expressões sensíveis produzidas pelo mal-estar físico ou mental. Ao reconstruir o caso de Mazinha. Neuza enfatiza que a filha, além do problema com a mão direita, sentia dores de cabeça, estava irritada e agressiva com os outros. Esses dados constituem expressões diretas do sofrimento. Contudo, cabe notar que se a enfermidade se inicia com a presença de sensaçōes corporais ou mentais, isso não prova que toda ela derive dessa experiência. A "matéria bruta" das expressões sensíveis, tomada isoladamente ou formando uma miríade de sensações coligadas, não oferece por si nenhum significado.

As expressōes diretas do sofrimento precisam ser organizadas em uma totalidade dotada de sentido. A enfermidade existe quando se atribui a uma dada experiência sensível um conjunto de significados. Nesse aspecto, enfermidade não é um fato, mas interpretação e julgamento de um conjunto de informaçōes heterogêneas vindas do corpo humano. Desnecessário é dizer que essa construçāo não é simples criação autônoma de significado por indivíduos isolados, mas resultado de processos de socialização.

Podemos observar pela fala de Neuza que nāo há forma de estabelecer prontamente uma relação biunívoca entre sintomatologia e etiologia. O que os "sintomas" apresentados por Mazinha indicam é apenas uma ruptura do processo comunicativo entre ela e as pessoas do seu círculo familiar e de vizinhança. Mazinha, conforme Neuza, quebra alguns padrões morais de conduta como, por exemplo, respeitar e obedecer a mãe. A percepção de que a filha estava com um problema não foi resultado de uma configuração imediata de estímulos já dotada de uma significação própria. A experiência cognitiva de Neuza se realizou ao longo de sucessivas interaçōes com familiares, vizinhos e terapeutas.

A indeterminação da relação entre sintomatologia e etiologia permite que existam sempre espaços para diversas interpretações da enfermidade. Essas interpretaçōes não esgotam todas as possibilidades de entendimento de um determinado caso, apenas esclarecem aspectos passíveis de uma interação com as circunstâncias e predisposições de quem 
percebe. Conseqüentemente, há sempre uma ampla margem de "possibilidades" interpretativas para a situação em que se encontra o enfermo. Por outro lado, a natureza processual e "aberta" das interpretaçōes conduz a incertezas que o indivíduo usualmente sente sobre a condição enferma. Essa relação entre possibilidades e incertezas é um elemento significativo para explicar a construçāo do discurso sobre a enfermidade.

Analisemos com um pouco mais de detalhes a explicaçāo de Neuza para a enfermidade da filha. Inicialmente ela atribui a Mazinha um "problema mental" que a medicina profissional poderia solucionar. Não satisfeita com o resultado do diagnóstico do médico ("botar óculos"), Neuza procura outras explicaçōes. Termina por acreditar que a filha estava com um "encosto", sofrendo da interferência de um espiríto que se alojara em seu corpo. Foi este o diagnostico que algumas vizinhas e parentes deram para o caso e que Dedéu, o pai-de-santo, e a segunda rezadeira confirmaram. É importante observar que embora "encosto" seja uma categoria explicativa central entre amplos setores da população brasileira, trata-se de uma categoria bastante ampla e passível de diferentes interpretaçōes.

Coube ao pai de santo e à rezadeira, em última instância, estabelecer uma explicação autorizada sobre o complexo de eventos ligados ao problema de Mazinha. $\mathrm{O}$ que ambos enfatizaram não foi a presença em si do "encosto", mas o porquê desse fenômeno (i. e., a cadeia de eventos que o produziu). São justamente esses quadros interpretativos que constituem os modelos cognitivos destas instituições terapêuticas. Tais modelos, por outro lado, ao procurar ordenar a enfermidade em um quadro coerente-explicativo podem reduzir, ou mesmo suprimir, a carga emocional que acompanha o epiśdio da doença.

Nenhum dos modelos cognitivos das agência procuradas por Neuza atendeu satisfatoriamente seus interesses. Não atendeu porque, em primeiro lugar, não solucionou o objetivo básico de Neuza: curar a filha. Além do mais, Neuza nunca ficou plenamente convencida da veracidade das explicações dadas e, conseqüentemente, não houve uma adesão propriamente dita a nenhum dos modelos explicativos oferecidos pelas agências. Até o último contato mantido com Neuza, suas incertezas e inquietaçōes não tinham terminado por completo. Prosseguia agregando novas interpretações após cada escolha de tratamento. Assim, nenhuma das agências representou para ela uma totalização a priori. A narração de Neuza evidencia um campo de possibilidades justamente porque ela não adota uma única linha de desenvolvimento determinável a priori. Nesse aspecto reproduz ambigüidades $\mathrm{e}$ incertezas.

Essas observaçōes nos levam a concluir pela não-existência de modelos cognitivos subjacentes às práticas médicas de Neuza ? A resposta seria não. $O$ que se pode concluir é que Neuza, circulando por diversas agências, de muitas formas e em diferentes momentos, não se deteve em nenhum dos modelos interpretativos oferecidos, de tal forma que possamos avaliar sua prática e seu discurso segundo o conteúdo diferencial de uma determinada agência. As instituições a que recorreu apresentaram a Neuza um conjunto de universos simbólicos que utilizou nas suas interações sociais concretas e opções cotidianas. Assim, temos que levar em consideração que esses universos simbolicos devem ser apreendidos dentro de situações biograficamente determinadas. Estão subrnetidos a um fluxo de vivências, a interesses pessoais e a motivos pragmáticos.

É preciso direcionarmos a nossa atenção para os processos interativos desenvolvidos entre Neuza e o seu círculo de relações. É interessante observar que nas suas escolhas 
e avaliações de tratamento, Neuza sempre se refere à indicação de uma vizinha, parente ou amiga. Essas redes de relações sociais legitimam as explicações e opções tomadas por ela. Isso significa dizer que a estrutura subjetiva de significados do discurso de Neuza tem origem social, ou seja, é resultado de contatos socialmente objetivados. É através de processos dialógicos que ela manteve e mantém não só com os agentes terapêuticos, como também com os "outros significativos" da sua comunidade, que Neuza cria ininterruptamente explicações para o problema da filha. Assim, os modelos interpretativos que ela desenvolve são essencialmente processuais, pois resultantes de constantes contatos e discussões mantidos ao longo da enfermidade.

\section{CONCLUSÃO}

Afetando diretamente o desempenho de rotinas e tarefas cotidianas, epiśdios de doença levam muitas vezes à reflexão e questionamento de posições dos indivíduos no meio social (Taussig, 1980). Durante o curso e desenvolvimento da doença, sinais de desconforto sāo transformados em sintomas de aflição imbuídos de sentido: etiologias relacionam um conjunto complexo de qualidades, fatos, objetos e eventos, implicando asserções mais gerais acerca das relaçōes entre o indivíduo e o meio (Frankenberg, 1980)

A construção de significados atribuídos ao problema da enfermidade mental, contudo, nāo pode ser totalmente reduzida a asserçōes lógicas ou a conjunto de modelos explicativos. É inegável que o điscurso sobre a enfermidade, tomado em si mesmo, seja estruturado em termos lógicos. Mas os processos fundamentais de interpretar a enfermidade não ocorrem simplesmente por asserçōes lógicas ou por juízos teóricos estruturados em modelos cognitivos. É necessário levar em consideração que o senso comum contém inumeráveis interpretaçōes pré-teóricas, admitidas como certas, sobre a realidade cotidiana (Schutz, 1962). O discurso é uma construção a posteriori de situações sociais concretas vivenciadas pelos atores sociais. Necessitamos, portanto, compreender as raízes existenciais e intersubjetivas subjacentes aos discursos da enfermidade.

O discurso da enfermidade é dotado de sentido na medida em que é afirmado como

real para os indivíduos. É real porque justamente é originado e legitimado em primeira instância no mundo do senso comum. É preciso que compreendamos esse discurso como resultante de processos interativos e comunicativos através dos quais os indivíduos constroem uma rede de significados para as suas experiências aflitivas. Na construção de sentidos, fatores intersubjetivos e existenciais mesclam-se com formas culturalmente padronizadas de interpretaçāo. Nesse aspecto, as estruturas cognitivas devem ser criticamente analisadas enquanto resultado de condiçōes sociais da produçāo do conhecimento. Assim, os modelos cognitivos devem ser examinados em sua plasticidade, em sua capacidade de responder aos desafios das circunstâncias, pela elaboração contínua de novos módulos de adaptação e novas justificações da experiência. Parafraseando Young (1982:272), podemos dizer que nenhum conjunto singular de estruturas cognitivas é, a priori, a fonte última de significados subjacentes às experiências subjetivas da enfermidade. 
Acreditamos, portanto, que a compreensão das estruturas cognitivas que organizam as interpretações da enfermidade mental - um dos objetivos centrais da Etnopsiquiatria - deva ser complementada pela análise dos microprocessos sociais subjacentes a essas estruturas. Torna-se necessário, portanto, que possamos perceber, através de uma análise hermenêutica, os processos pelos quais os indivíduos e grupos sociais vivenciam, explicam e procuram ajuda para os problemas concretos da enfermidade. Enquanto não examinar criticamente as estruturas cognitivas como resultado de condições sociais da produção do conhecimento, a Etnopsiquiatria não poderá cumprir satisfatoriamente o seu papel de interdisciplinaridade, ou transdisciplinaridade, entre a Psiquiatria, Antropologia e Sociologia. 


\section{REFERÊNCIAS BIBLIOGRÁFICAS}

ALVES, P. C. (1993). A Experiência da Enfermidade: Considerações Teóricas. Cadernos de Saúde Pública, 9(3): 263-271.

BERGER, P. \& LUCKMANN, T.(1973). A Construção Social da Realidade. Petrópolis, Vozes.

DEVEREUX, G. (1961). Mohave Ethnopsychiatry and Suicide: The Psychiatric Knowledge and the Psychic Disturbances of an Indian Tribe. Bureau of American Ethnology Bulletin, No. 175. Washington, D.C. Smithsonian Institution.

FRANK, J. D. (1961). Persuasion and Healing. Baltimore, The Johns Hopkins Press.

FRANKENBERG, R. (1980). Medical Anthropology and Development: A theoretical Perspective. Social Science and Medicine, 14b: 197-207.

KIEV, A. (Ed) (1964). Magic, Faith, and Healing. New York, Glencoe Free Press.

PELBART, P. P. (1990). Manicômio Mental - A outra face da clausura. Saúde e Loucura, $\Rightarrow$ (dir. Antonio Lancetti). São Paulo, Hucitec.

PRICE, R. (1960). The Use of Rauwolfia for the Treatment of Psychoses by Nigerian Native Doctors. American Journal of Psychiatry 118:147-149.

SCHUTZ, A. (1962). Collected Papers, vol I. The Hague: Nijhoff.

TAUSSIG, M. (1980). Reification and the Consciousness of the Pacient. Social Sciences and Medicine, 14B:3-13.

YOUNG, A. (1982). The Anthropologies of Illness and Sickness. Ann. Rev. Anthropol. 11:257-85. 


\title{
8 \\ o CORPO SÍGNICO
}

\author{
JAQLELINE FERREIRA
}

Este estudo concentra-se na área de Antropologia Médica. Este ramo da Antropologia é definido como um campo de estudo que se preocupa com como as pessoas, em diferentes culturas e grupos sociais, explicam as causas relacionadas a saúde e doença, as crenças sobre tipos de tratamentos e a quem recorrer quando doente. É também o estudo das crenças e práticas relativas ao corpo, tanto nos estados de saúde como no de doença.

Meu objetivo é buscar a representação de corpo doente, mais especificamente a expressão do corpo doente apresentada ao médico pelos pacientes, através dos sintomas. Igualmente busco relacionar estes sintomas a aspectos observados clinicamente na consulta médica. A metodologia, portanto, centra-se na observação participante, em entrevistas e na observaçāo da consulta médica realizada na Lomba do Pinheiro, uma vila de classes populares situada na zona leste de Porto Alegre*.

Inicialmente destaco que o corpo é pensado, representado e passível de leituras diferenciadas de acordo com o contexto social, tornando-se assim um importante objeto de estudo dentro das ciências sociais. O corpoé um reflexo da sociedade, nāo sendo possível conceber processos exclusivamente biológicos, instrumentais ou estéticos no comportamento humano. Ao corpo se aplicam sentimentos, discursos e práticas que estão na base de nossa vida social. Por sua vez, o corpo é emblemático de processos sociais. Neste sentido, o estudo do corpo torna-se imprescindível não só para especialistas das áreas biomédicas como para os cientistas sociais.

Para os especialistas da área da saúde, a importância deste estudo concentra-se no fato de que o corpo é o depositário de processos biológicos indicadores de saúde ou doença para o indivíduo.

Foucault (1980), em O Nascimento da Clínica, nos mostra como o corpo, sendo espaço de doença, torna-se um texto passível de diferentes leituras em busca de significados tanto para o doente, no processo de desencadear sintomas, como para o clínico, quando

Minha inserção no campo deu-se através do consultorio médico, espaço criado com o fim específico de desenvolver esta pesquisa, aliando, desta forma, minha formaçāo em Medicina Geral Comunitária com a Antropologia Médica. 
persegue sinais, indícios, ao examinar o corpo do outro, o doente, e encontra assim as formas visíveis da doença.

As sensações corporais experimentadas pelos indivíduos e as interpretações médicas dadas a estas sensações serão feitas de acordo com códigos específicos a estes dois grupos. A capacidade de pensar. exprimir e identificar estas mensagens corporais está ligada a uma leitura que procura determinada significação. Esta leitura está na dependência direta da representação de corpo e de doença vigente em cada grupo. Neste sentido, o corpo pode ser tomado como um suporte de signos, ou seja, suporte de qualquer fenômeno gerador de significação e sentido. Para tornar isto mais claro tomemos como exemplo um indivíduo que em determinada ocasião sente uma "dor de barriga". Esta dor o incomoda e portanto ele pensa em procurar um médico. Ao consultar o médico terá que relatar a sua dor, e para isto procura palavras que este médico possa compreender, já que sua sensação é individual e experienciada de forma confusa. Assim, este indivíduo tenta definir a sua dor e procura prestar atenção a esta sensação. Será uma dor em "pontada", "uma fisgada" ou "latejante"? Tenta desta forma dar à sua experiência pessoal uma qualidade que seja socialmente reconhecida, de forma que o médico em questão saberá relacioná-la com sua própria experiência. À medida que este indivíduo procura dar um nome a estes estímulos confusos, ele os culturaliza, isto é, torna o que era um fenômeno individual em um fenômeno que pode ser reconhecido por outros indivíduos de seu grupo. $O$ médico, ao ouvir o relato, compreende as palavras, mas quer mais informaçōes: qual a localização exata da dor? quando começou? qual o seu período de duração? são alguns questionamentos que ele se faz. Ele já pode ter hipóteses diagnósticas, mas precisa de mais elementos para confirmá-la. Para isto, parte para o exame clínico: examina a pele, a forma do abdômen palpa a região em alguns locais mais profundamente e demoradamente que em outros para ele certas experiências táteis têm significados que para os outros não têm. Realiza a escuta do abdômen, pois conhece sons dali advindos que podem caracterizar um estado de alteração. Por fim, reúne todos estes elementos, os quais na maioria das vezes são suficientes para formular um diagnóstico. Finalmente, pensa em chegar ao seu paciente e lhe dizer: "o sr. está constipado", mas neste momento the ocorre que o seu paciente pode não conhecer este termo, e assim reformula a sua fala lhe dizendo: "o que o senhor tem é o intestino preso". Desta maneira, pode-se pensar na idéia de corpo como signo se tomarmos aqui o conceito de signo utilizado por Barthes (1971) ${ }^{*}$. Para este autor, a função do signo é comunicar idéias por intermédio de mensagens, ou seja, o signo tem o objetivo de transmitir uma informação, fazendo parte assim de um processo de comunicação. Estas mensagens que o signo visa comunicar têm o objetivo de produzir um conteúdo na consciência, onde a mensagem é o significante e o conteúdo o significado. Aproprio-me desta noção ao referir-me ao corpo como signo, à medida que, através de determinadas mensagens emitidas pelo corpo, os sintomas experienciados pelo indivíduo e os sinais observados no exame clínico do médico levam a um significado, a doença. O signo só tem valor enquanto tal se compartilhado pelo grupo social. Este caráter eminentemente social do signo é percebido pelo fato da necessidade de que a cultura tenha definido elementos

* É muito extensa e especializada a literatura neste tema. Preferi o esquema adotado por Leach (1976), por considerá-lo mais adequado d̀ minha perspectiva. 
reconhecíveis com base em algumas características emergentes, de forma que possam ser compartilhados por todos os seus componentes. Do ponto de vista antropologico, a própria cultura é uma prática plena de significados, capaz de atribuir sentido a todas as significações sociais. É com esta perspectiva que Geertz (1989) toma as lutas de galo-de-rinha balinesas como um evento cultural que diz algo sobre algo, um discurso que pode ser interpretado como se fosse um texto*.

A noção de saúde e doença é também uma construção social, pois o indivíduo é doente segundo a classificação de sua sociedade e de acordo com critérios e modalidades que ela fixa. Isto implica que o saber médico também está intimamente articulado com o social, uma vez que ele constrói um diagnóstico tomando como ponto de partida as sensaçōes desagradáveis descritas pelos pacientes, ao que chamamos de sintomas, e através de aspectos constatados objetivamente pelo médico, o que é chamado de sinais. $O$ estudo dos sintomas e sinais diz respeito à semiologia médica, uma disciplina no campo da medicina destinada ao estudo dos métodos e procedimentos do exame clínico, de modo a buscar o corpo como gerador de signos, da mesma forma que a semiologia geral preocupa-se com a linguagem enquanto geradora de signos. É na procura dos sintomas e sinais que o médico coordena todos os elementos para construir o diagnóstico e deduzir o prognóstico. Mas o que são estes sintomas e sinais? Romeiro (1980) nos dá uma definição:

"Sintoma é a sensação subjetiva referida pelo doente como dor, ansiedade, mal-estar, alucinações, sensação de vertigem, etc. É um fenômeno só por ele sentido e que o médico, ordinariamente, não percebe nem lhe é fácil comprovar, sendo revelado apenas pela anamnese ou interrogatório.

Sinal é a manifestação objetiva da doença, física ou química, diretamente observada pelo médico ou por ele provocada, como tosse, alteraçōes da cor da pele, ruídos anormais do coração, convulsões..." (Romeiro, 1980:3)

O sintoma, portanto, diz respeito única e exclusivamente ao doente, é o caráter invisível da doença, pois nada mais é que sensações que o indivíduo experimenta e só pode expressar por meio de palavras. Já o sinal, como manifestação objetiva, faz parte do aspecto visível da doença, e diz respeito principalmente ao domínio médico, pois se constitui de sua observação e do exame físico.

Em relação ao sinal, a observação do paciente desde o primeiro momento de contato (o trajar e o falar, por exemplo), já são elementos de análise para o médico. Quanto ao exame físico, ele se fundamenta no uso dos sentidos do médico: visão, audição, tato e olfato. Embora haja uma rotina básica geral de realização do exame físico, que visa evitar a omissão de órgãos ou segmentos, é diferente a significação de cada etapa de exame físico de cada órgão. Gostaria de me deter, neste momento, especificamente no aspecto dos sintomas.

Segundo Foucault, o destaque ao sintoma como a única forma de acesso à doença no sentido hipocrático perdura até o século XVIII. Para ele, com o advento da clínica

* Neste sentido, para um conceito semiológico de cultura, ver também Geertz (1989). 
anátomo-patológica há uma reformulação do saber, onde a semiologia médica passa a ser um conjunto de técnicas que permite aliar a leitura dos sintomas com a pesquisa dos sinais onde entram em jogo a escuta e o olfato, além do olhar já existente. Com o advento da patologia, como campo institucionalizado de conhecimento, o acesso à doença tornou-se visível.

Com isto, não é mais uma determinada patologia que se insere no corpo, mas é o próprio corpo que se torna doente. Em consequiência disto, como foi dito, há uma reformulação do saber, onde a semiologia médica passa a ser um conjunto sistematizado de técnicas e, legitimado como uma área específica do conhecimento científico, permite aliar a leitura dos sintomas com a pesquisa dos sinais. Foucault refere que daí decorre que cada órgão dos sentidos do clínico recebe uma função instrumental, onde a visão, o tato e a audição fazem com que um mal inacessível seja trazido à superfície, sendo deixado à mostra. Os sinais visíveis para o médico englobam desde a expressão facial, a marcha, a postura corporal e tudo o que recobre o tecido da pele e membranas. $O$ tato permite demarcar tumores ou massas viscerais, e através do ouvido clínico pode-se perceber sons advindos do tórax ou abdômen. Assim, para Foucault, a medicina é uma ciência do olhar, que se desdobra com o advento da anatomia patológica. Quando o médico observa, com todos os seus sentidos, há uma especificidade do olhar que lhe confere um saber distinto. No entanto, este saber não é absoluto nem universal. A anatomia e a fisiologia do corpo só se tornam significativas a partir das regras e códigos dos grupos. Isto se vincula ao ponto que é central neste trabalho, sobre a dependência direta que os doentes e os clínicos possuem com representaçōes sociais específicas a respeito do corpo, saúde e doença, relativas ao contexto social em que se inserem.

Mas como é que o próprio doente lê estas sensações de doença? Muitos estudos destacam que as representações que os indivíduos possuem a respeito de doença estão diretamente relacionadas com os usos sociais do corpo em seu estado normal. Assim, qualquer alteração na qualidade de vida, como por exemplo, quando o indivíduo não consegue trabalhar, comer, dormir ou realizar qualquer outra atividade que habitualmente está acostumado, implica estar doente. Mas como se traduz a percepção deste estado? Isto foi observado em meu trabalho etnográfico na Lomba do Pinheiro, onde colhi depoimentos com meus informantes sobre o que é o se sentir doente. Os relatos confirmam a noção de que qualquer prejuízo às atividades normais é considerado um estado doentio que é percebido por sensaçōes desagradáveis: cansaço, fraqueza, dor, mal-estar..., ou seja, percebidos como sintomas. Pode-se dizer sem dúvida alguma que a percepção do estado de doença quase sempre se traduz em sintomas. Em todos os relatos um sintoma está sempre presente: a dor. Também no consultório médico esta sensação é a mais freqüentemente relatada pelo paciente como indicaçāo de doença e é inclusive o principal motivo de consulta. Devido a esta recorrência, desenvolverei um pouco mais sobre o que está envolvido na representação de $d o r$. 


\section{DOR, UMA SENSAÇÃO PECULIAR}

O que é a dor? Qualquer um de nós pode se reportar à sua experiência pessoal e dizer que sabe o que é a dor, ainda que a busca de palavras para expressar esta sensaçāo seja difícil. Muitas definições podem ser dadas, mas nunca abarcarão a dimensão do que é esta sensação, isto porque a dor é uma experiência subjetiva, privada e qualquer informação sobre ela há de provir apenas daquele que a sente. Às vezes pode-se deduzir pelo comportamento, postura e expressões faciais que o indivíduo está sentindo dor e por estas indicações até pode-se localizá-la, mas os demais aspectos a seu respeito só aquele que a sente pode informar. Talvez o fato de ser difícil descrevê-la faz com que recorramos constantemente a imagens e metáforas para representá-la, como por exemplo: "facadas", "pontadas" e "agulhadas", o que abordarei mais adiante.

Para Joana, de 45 anos e dona-de-casa, a dor é "sinal de que alguma coisa está errada no organismo, dor é sofrimento". Os depoimentos dos informantes como a literatura médica em sua essência, não diferem. Em ambos os casos, a dor é indicada como sensação desprazerosa e sua condição de sintoma torna implícita a possibilidade de uma patologia. O fato de as palavras dor e doença possuírem uma raiz etimológica comum (no latim, dolor e dolentia) é por si só bastante expressivo da íntima relação que existe entre a experiência de dor e o reconhecimento de um estado mórbido. A dor sempre nos reporta à idéia de sofrimento, como diz Joana, e a simples perspectiva de dor causa um sentimento de aversão, o que a faz surgir na consulta médica como o mais comum e elementar dos sintomas. Assim, dominá-la é um dos grandes desafios da medicina. Do ponto de vista clínico, a dor exerce um papel fundamental ao demonstrar que algo não vai bem no organismo.

Se a maioria dos males corporais são acompanhados de dor, ela é um importante fator diagnóstico para o médico, e o fato de indicar ao indivíduo a ocorrência de alguma alteração em seu corpo a faz ser um mecanismo de proteção do organismo. Nem sempre, no entanto, a dor é indicativa de enfermidade, já que ela pode estar presente em fenômenos biológicos normais, como por exemplo o parto. Por outro lado, sua ausência também não é indicativo de silêncio orgânico, uma vez que certos tumores malignos, por exemplo, podem evoluir por algum tempo sem provocar dor alguma. Paradoxalmente, a dor pode se fazer presente em procedimentos de cura e diagnóstico como as operações cirúrgicas, injeçōes e biópsias.

O fato de a dor ser uma resposta biológica universal e individual a estímulos nocivos advindos de dentro do corpo ou fora dele, não exclui que sua percepção e tolerância variem significativamente conforme o grupo social. A sensação de dor, os comportamentos que a envolvem, quer verbais ou não, até as atitudes que visam a remover ou não a sua fonte, dizem respeito às expectativas do sujeito, suas experiências passadas e principalmente a toda a sua bagagem cultural. Helman (1984) é um dos autores que defende que cada cultura ou grupo tem sua própria linguagem para representar a dor, o que depende, entre outros fatores, dos valores relativos ao grupo em questão. Assim, ele realiza uma comparaçāo entre italianos, mais expansivos, e os irlandeses, mais comedidos, onde os primeiros tendem a dramatizar a sua dor enquanto os segundos tendem a negá-la. Helman nos fornece vários exemplos de como diferentes sociedades podem reagir à dor, segundo o caráter público ou privado. Para ele, a dor é por excelência um dado privado, onde para se saber 
que uma pessoa tem dor é necessário que ela nos assinale, quer verbalmente ou não. Mas em algumas sociedades a dor pode assumir um caráter público. É o caso de algumas culturas onde a exibição da dor faz parte dos rituais de passagem dos meninos à idade adulta, ou em rituais de autotortura que visam angariar prestígio social. Clastres (1978) igualmente nos fornece vários exemplos de sociedades primitivas onde a tortura é a essência do rito de iniciação. Segundo Clastres, essa crueldade imposta ao corpo e que tem como resposta o silêncio, não visa apenas avaliar a capacidade física dos jovens e tornar a sociedade confiante na coragem de seus membros, mas também tem o objetivo de imprimir uma marca no corpo dos jovens através de cicatrizes que trazem determinado significado para o grupo, conforme foi referido anteriormente. Barthes (1985) nos mostra como a dor pública também surge nas sociedades modernas. $O$ exemplo que ele nos oferece é o catch, que corresponde à luta livre no Brasil. Barthes se refere ao catch não como a um esporte, mas como a um espetáculo, o "espetáculo do sofrimento". Aqui, a exposição da dor é a própria finalidade do combate, não que seja um espetáculo sádico, mas apenas inteligível à medida que o público constata não só o sofrimento, mas o porquê deste sofrimento, já que os atos geradores de sofrimento são particularmente espetaculares e fazem com que a dor seja infligida com limpidez e convicção. Para Barthes, o objetivo deste espetáculo é uma série quantitativa de compensações (olho por olho, dente por dente) minando o conceito moral de justiça, já que se justifica violar a regra em prol de um castigo merecido. Através destes exemplos podemos perceber que por trás de toda exposição pública de dor há significados sociais subjacentes.

Salem (1983) coloca que as técnicas que visam abolir a dor do parto já tinham por princípio que a dor não era inerente ao parto, sendo antes a expressão de "constrangimentos socioculturais, estes sim responsáveis pela relação entre feminilidade, passividade e dor". Tendo isto em vista, esta técnica de parto sem dor buscava a reeducação física e psíquica da gestante, por meio de treinamento centrado em técnicas de respiração e informaçōes sobre a fisiologia feminina, a gravidez e o parto. Aqui, a representação de corpo se faz indicativa na percepção da dor, onde o agir sobre estas representações é o que tem a capacidade de alterar a qualidade e intensidade do tipo da dor.

Boltanski (1984) é outro autor que cita que a percepção de dor varia conforme o grupo social. Segundo ele, a percep̧̧ão da dor como doença grave aumenta nas classes superiores em relação às baixas. A observação nos mostra, no entanto, que não é a percepção da dor que varia conforme a classe, mas sim a continuidade das atividades e a busca de alívio para a mesma.

Luis, de 43 anos, por exemplo, é operário e veio à consulta com dor abdominal que persistia há um mês, a despeito de chás caseiros ou analgésicos indicados pelo farmacêutico. Referiu a dificuldade de buscar auxílio médico, uma vez que isto implicaria faltar ao trabalho, o que resultaria na perda do rancho mensal, somente fornecido ao trabalhador assíduo. Este é apenas um exemplo de como é freqüente o fato de que muitos representantes das classes populares persistam no trabalho mesmo com dor, e talvez por este mesmo motivo busquem menos auxílio médico, não significando que não lancem mão de outros recursos, como medicina caseira ou benzedeiras.

Já comentei o fato de a dor ser o sintoma mais comum em virtude do qual o paciente procura o médico. De fato, alguns não se consideram doentes se não a sentirem. Já um 
tumor indolor, que para o médico é um indício de uma possível patologia, pode ser desprezado pelo paciente simplesmente "porque não dói". Mencionei também como é importante observar que tanto a percepção da dor como a procura de recurso médico para o seu alívio está diretamente relacionada com as representações de corpo. Assim, por exemplo, uma dor na perna pode não ser considerada grave, tornando-se mais fácil de tolerar e o indivíduo podendo se contentar em simplesmente tomar uma aspirina em casa ao invés de procurar recurso médico. Por outro lado, uma dor torácica é logo relacionada com a hipótese de uma patologia cardíaca, o que faz com que muitas vezes o indivíduo recorra a vários serviços de saúde e exija uma série de exames subsidiários a fim de se tranquiilizar. Em outros casos a dor é considerada um fenômeno normal, não implicando o sentimento de estar doente. O caso mais típico é a dismenorréia ${ }^{*}$, onde esta sensação diz respeito à representação de corpo feminino, em que este fenômeno é encarado como fazendo parte da vida da mulher.

Do ponto de vista estatístico, as dores mais comuns que aparecem na consulta médica são a dor de cabeça e a dor abdominal. Sabe-se pela literatura médica e pela experiência clínica que as dores mais intensas que podem atingir o ser humano são as provocadas pelo infarto do miocárdio e as cólicas renais. Entre as dores crônicas se destacam as dores reumáticas e o câncer. Nestes casos, a dor como sensação crônica passa a ser uma moléstia em si mesma, uma entidade própria, como diz Emília, minha informante, ao comentar o caso de sua amiga que está com câncer e combatendo a dor à base de sedativos potentes:

\section{"Ela não se queixa de dor por causa dos remédios fortes que} eles dāo, mas a dor tá aí." (Emília, 62 anos, dona-de-casa)

Já me referi antes às dificuldade de descrever a dor. Assim, há várias associações, metáforas e jogos simbólicos que os indivíduos lançam mão para representá-la e melhor explicitá-la, sobretudo na situação da consulta médica. Muitos a descrevem de acordo com suas atividades cotidianas. Eulália, por exemplo, dona-de-casa de 73 anos, me descreve a sua dor como "uma dor na perna que parece que estão cortando e botando sal e vinagre em cima", e o mecânico Jorge, de 51 anos, que tem uma dor de ouvido, descreve "que dá a sensação de pneu esvaziando".

As associações como "facadas", "agulhadas", "socos", são freqüentes, representando a dor como forma de agressāo, como algo socialmente identificado como violento, uma vez que a violência está plenamente inserida neste contexo social. As pessoas vivem ou viverão csta experiência, scja como vítima ou como autor, onde a violência não se restringe somente ao crime, mas também ao desemprego, à falta de moradia, a condiçōes de trabalho insalubres, só para citar algumas. Particularmente, para os moradores da Lomba do Pinheiro a violência faz parte do seu cotidiano. Além das baixas condiçōes socioeconômicas da maioria dos moradores. os crimes são freqüentes, o que faz o bairro ser identificado como violento pela população em geral. Há gangues que se reconhecem pelas siglas: VIP (Violência Integrada do Pinheiro), D.P. (Demônios da Pinheiro), G.F. (Gangue da Firmina), cujos nomes são por si só significativos. São compostas de menores, 
moradores do bairro, e é comum realizarem depredação dos ônibus que fazem a linha no local. Com a violência fazendo parte da vida diária e tendo a dor como representação de agressão é fácil entender o uso deste tipo de metáfora. Descrevo aqui uma série de relatos a fim de demonstrar como a associação de dor e agressão é recorrente:

"Eu tive uma dor em pontada no peito. Até falei: Toni (marido), estäo me esfaqueando. Qualquer dia eu morro do coração por causa desta dor." (Luciana, 23 anos, donade-casa)

"Tenho una dor em pontada no peito como se fosse um espinho...semana passada tive uma dor de barriga como se fosse ganhar um filho." (Zilma, 33 anos, dona-de-casa)

"Tenho uma ferroada que dá de um lado e pro outro e vai pras costas." (Loreci, 29 anos, doméstica)

"Estou com uma dor no estômago, unı dor apertada, parece que estäo torcendo o estômago... a dor de cabeça é em ferroada. parece que está entrando uma agulha." (Miriam, 51 anos, auxiliar de creche)

"Tenho uma dor de cabeça que parece que tem um bicho que come dentro." (Terezinha, 36 anos, dona-de-casa)

"Há dois dias estou com dor de barriga, uma dor torcida nas tripas." (Elza, 54 anos, auxiliar da FEBEM)

Todos estes relatos demonstram a idéia de um ataque de um elemento externo (faca, espinho, ferrão, bicho) que se instala no interior do corpo. Isto implica a representação de dor como uma qualidade de sofrimento e tortura e de algo estranho ao corpo. Outros depoimentos significativos denotando o caráter de sofrimento da dor são o de Osvaldo e Marli:

"A dor no peito é tâo triste que parece que mói os ossos tudo. Se é uma pessoa que sofre do coração não agüenta. Eu me ralo de dor." (Osvaldo, 44 anos, vendedor)

"Acho que é câncer o que eu tenho porque a dor na barriga é una dor desesperada, que tá criando raiz. Estou desesperada de dor." (Marli, 43 anos. doméstica)

Estes relatos demonstram a dor associada à tristeza e ao sofrimento intenso, o que inclusive faz Marli ao associar com uma doença mais grave, o câncer. No senso comum, este vocábulo, "câncer", está intimamente associado à idéia de dor e morte. Sontag (1984) refere-se que sempre se atribui que o câncer é extremamente doloroso e que dele advém uma "morte horrível". Isto Marli demonstra ao ilustrar o sentimento que ambos, a dor e a doença, lhe trazem: o desespero diante da iminência do sofrimento, onde está implícito o medo da morte. Pode-se ir mais longe e dizer que dor e morte são indissociáveis, à medida que dor está para doença assim como a doença está para a morte. Foucault (1980) já dizia 
que "não é porque caiu doente que o homem morte; é fundamentalmente porque pode morrer que o homem adoece." É este medo da morte que faz com que a dor seja muitas vezes valorizada, a despeito do sofrimento que dela pode advir. Este paradoxo entre a valorização da dor e do sofrimento se justifica a fim de se evitar a doença e sua conseqüência última, a morte, que parece ser o sofrimento maior.

É interessante a associação que Marli faz da dor como "criando raiz". A iđéia de criar raiz nos faz pensar que a dor de Marli tanto pode aludir à sensação de dor que cresce e se espalha, como também à dor se sedentarizando e adquirindo um local fixo, uma morada. Isto também nos remete mais uma vez à relação que Marli faz da dor com o câncer, por ser algo definitivo, sem solução, que não partirá mais do corpo em que se alojou. E neste mesmo sentido podemos pensar que o câncer, como diz Sontag (1984), é uma "doença do espaço" à medida que suas principais metáforas se referem à sua topografia: o câncer "se espalha" ou "prolifera" ou "se difunde" ou "é extirpado" cirurgicamente. Pode-se concluir que para Marli, dor e câncer possuem a mesma significação.

Referi-me acima sobre a dor sendo diretamente identificada com o câncer e como ela pode constituir-se em um espaço. Não é somente a categoria espaço que a dor pode transmitir, mas também a categoria de tempo. Isto ficou mais evidente ao presenciar a conversa de minha informante Ione com sua vizinha, quando comentavam sobre o câncer de uma "comadre" de Ione e de como se "admiravam" de ela ainda não estar sentindo dor:

\section{"Ela nunca se queixou de dor? (perguntou Terezinha)}

Não, é que este câncer só dói nos últimos mês de vida." (Ione, 42 anos, dona-de-casa)

Assim, observamos como a dor tem o seu tempo de aparecimento e de término, que neste caso coincide com o fim da vida. Entretanto, esta categoria de tempo da dor não se exprime somente em termos de início e de término, como também em termos de sua duração, uma vez que tanto a dor como qualquer outra sensação desagradável é experienciada como um tempo longo. Um exemplo claro disto é quando tivemos poucas horas de insônia à noite e temos a sensação de que estivemos despertos a noite inteira.

Ainda sobre os relatos acima, podemos concordar com Boltanski (1984), que classifica as características da dor conforme a sua localização. De acordo com este autor, as dores torácicas são referidas como puntiformes $\mathrm{e}$ as dores abdominais como esfenoidais, por exemplo.

Isto condiz com as falas de Luciana e Zilma, que se referem à sua dor no peito como "pontadas", e Miriam e Elza, que sentem dor abdominal como se estivessem "torcendo" seus órgãos internos, o que corresponde ao que o autor chama de "dor esfenoidal". A sensação de "bola na barriga" é muito comum para descrever as dores abdominais e dizem respeito à sensação desagradável de um volume anormal no abdômem e com a idéia implícita de algo não digerido. Algumas vezes são feitas relaçōes diretas com algum objeto específico, como no exemplo acima, "um bicho que come", ou como minha informante, Terezinha, que sentia dor abdominal "como se estivesse cheia de algodão". Do ponto de vista cognitivo, a sensação de dor só consegue ser transmitida através da eleição de um objeto que por suas características passa a ser emblemático da dor. 
A dor também pode representar categorias de quente-frio e de diferentes estados de matéria, pois estas são experiências familiares ao indivíduo. Isto é, o quente e o frio são sensações comuns em nosso cotidiano e só se tornam um estímulo doloroso quando em excesso. Através de nossa própria experiência sabemos como um contato com um objeto extremamente aquecido ou resfriado pode nos causar dor. É esta sensação que tanto Sílvia como Marlene querem transmitir nos seguintes relatos:

"Parece que escorre um liquido quente aqui na nuca." (Sílvia, 43 anos, doméstica)

"Tenho uma dor no umbigo por dentro, parece que corre uma água gelada." (Marlene, 43 anos, dona-de-casa)

Conforme Sílvia e Marli, a dor pode ser "líquida", o que indica um estado de matéria e uma dinâmica da própria sensação dolorosa, onde há a idéia de um fluxo fora de lugar e fora de controle. Este aspecto também é muito recorrente:

"Parece que a minha cabeça está cheia de agua e se eu abaixar parece que vai estourar nos ouvidos." (Rosa, 25 anos, dona-de-casa)

No sentido contrário, a dor também pode dar a sensaçāo de ser "sólida". É o caso dos depoimentos já citados acima, de sentimentos de "bola na barriga", "algodão na barriga" ou "bicho que come".

A dor também é percebida como seguindo uma trajetória própria pelo corpo:

"Tenho uma dor que começa no lado do umbigo, bem no ovário, e que vem morrer na perna." (Dione, 31 anos, donade-casa)

"A dor que eu tenho começa no ouvido esquerdo e caminha para o lado direito e vai até a perna. É uma eletricidade." (Francisca, 61 anos, dona-de-casa)

A possibilidade de um percurso da dor com início em determinado ponto, indo findar em outro, indica a autonomia desta. A própria idéia da dor como eletricidade referida por Francisca nos mostra como a dor pode ser percebida como dotada de energia própria, como um agente poderoso e interruptor do estado de harmonia e da idéia de uma suposta inércia do corpo, do silêncio orgânico significativo de saúde.

Em outras situações, para a dor são atribuídas qualidades de caráter moral, sempre capaz de produzir sensações, como por exemplo:

"Tenho uma dorzinha enjoada, às vezes incha dos lado, às vezes no estômago." (Aristides, 78 anos, aposentado)

Para Aristides, a dor enjoada, além da idéia de persistência, isto é, de sua dimensão temporal, significa o caráter de como esta dor lhe causa irritação e cansaço. De fato, Aristides veio à consulta após ter realizado várias "peregrinaçōes" em diversos ambulatórios e ter feito inúmeros exames laboratoriais sem alívio deste sintoma. 
Não se pode deixar de referir aqui que estas metáforas usadas para descrever a dor física muitas vezes também são usadas no nosso cotidiano para explicitar qualquer lipo de sofrimento moral, onde a dor é tomada como o próprio sofrimento em si mesmo. Assim, expressões que referem como determinado acontecimento foi "muito doloroso" ou que determinado fato "foi como se tivesse levado uma facada" são recorrentes cm nosso dia-adia em termos de senso comum, o que nos mostra que sendo física ou não, a dor é sempre um feixe de emoções desagradáveis. A dor é um tipo especial de sofrimento e assim pode suscitar as questões comuns a qualquer sofrimento ao perccbê-la como uma forma de punição: "Por que eu?", "O que fiz para merecê-la?", "Por que agora?". Segundo Helman (1984), nas sociedades não-ocidentais é mais direta esta ligação entre dor física e sofrimento moral, em comparação com as sociedades ocidentais. Nestes casos, muitas vezes a dor inclui ter uma etiologia como punição divina ou bruxaria, o que demanda tratamentos específicos tais como: orações, penitências ou exorcismo, onde drogas analgésicas mostram-se insatisfatórias, não se conhecendo plenamente os mecanismos psicológicos envolvidos.

Muito mais pode ser dito sobre a dor. Nesta breve exposição tentci demonstrar como a percepção e o relato a respeito da dor são influenciados por vários elementos. São eles a vivência cultural do doente, o seu repertório lingüístico, o seu domínio (ou não) de termos médicos, as suas crenças e representações sobre corpo e doença, as suas experiências individuais em geral, e suas experiências e sua memória específica quanto à sensação de dor. 


\section{REFERÊNCIAS BIBLIOGRÁFICAS}

BOLTANSKI, L. (1984). As Classes Sociais e o Corpo. Rio de Janeiro, Graal.

CLASTRES, P. (1978). Da Tortura nas Sociedades Primitivas. A Sociedade contra o Estado. Rio de Janeiro, Francisco Alves.

FERREIRA, J. (1994). O Corpo Sígnico. Porto Alegre, Tese de mestrado defendida pelo PPGASUFRGS.

FOUCAULT, M. (1980). O Nascimento da Clínica. Rio de Janeiro, Forense-Universitária.

GEERTZ, C. (1989). A Interpretaçāo das Culturas. Rio de Janeiro, Guanabara.

HELMAN, C. (1984). Culture, Health and Illness. London, Wrigtht-PSG.

LEACH, E. (1976). Cultura e Comunicação. Rio de Janeiro, Edições 70.

ROMEIRO, V. (1980). Semiologia Médica. Rio de Janeiro, Guanabara.

SALEM, T. (1983). O ideário do Parto Sem Dor: uma leitura antropológica. Rio de janeiro, In: Boletim do Museu Nacional, $\mathrm{n}^{\circ} 40$.

SONTAG, S. (1984). A Doença como Metáfora. Rio de Janeiro, Graal. 


\title{
"LUGAR DE MULHER": Representações sobre os Sexos e Práticas Médicas na Amazônia (Itapuá/Pará)
}

\author{
MARLA ANCELICA MOTTA-MAliÉs
}

\section{INTRODUÇÃO}

O universo social em Itapuá é marcado por representaçōes dos sexos que opōem homens e mulheres como categorias diferentes e desiguais e elege como parâmetro dessa classificação os processos ligados ao ciclo biológico feminino.

Através das crenças e rituais que informam e acompanham cada menstruação, gravidez, parto e resguardo, a sociedade aqui considerada - mas nāo só ela - inscreve nos corpos, nem sempre dóceis, de suas mulheres, as marcas da ambigüidade que lhes imputa, às quais, dada a extrema recorrência de sua impressão, a eles aderem (e às suas mentes) como se fossem parte de sua própria "natureza".

Assim, os estados fisiologicos femininos são marcados em Itapuá por uma série de desempenhos extremamente ritualizados, que relevam o modo como as pessoas interpretam o mundo e suas três ordens - natural, sobrenatural e social - e da visão diferenciada que dirigem aos dois sexos. Disso resulta um "lugar" para a multher que é sempre de sujeição (em relação ao homem) e um perfil ambíguo como fonte de vida (destaque ao papel de mãe) e de morte (como ativadora de forças destruidoras e dona de um poder perigoso).

Dentro desse contexto, dois elementos sāo de especial importância: os poderes perigosos atribuídos à mulher - veneno e panema - e a reima, sistema de classificaçāo que relaciona pessoas e alimentos.

Itapuá $\in$ uma pequena comunidade de pesca do município de Vigia (Para), onde vivi durante quatro meses, entre 1975/76 (com mais um na cidade de Vigia), fazendo trabalho de campo para o mestrado. Até 1981 desenvolvi projeto de pesquisa no município, tendo passado vários perfodos mais curtos na cidade de Vigia, onde até hoje mantenho contatos, mais ou menos regulares, com esses locais. 
Desse modo, através da descrição detalhada das concepções e práticas dos itapuaenses, relativas ao corpo feminino e aos estados próprios do cicio biologico da mulher, $e$ meu propósito neste trabalho sinalizar um modelo de sociedade que engloba essas concepções e essas práticas no conjunto maior das representaçōes sobre os sexos. Neste, as mulheres estão sempre em "natural" desvantagem, o que se justifica com uma recorrência às suas especificidades biológicas $\mathrm{e}$ às interdições de que são objeto.

\section{SER HOMEM VERSUS SER MULHER: DIFERENÇAS ANATÔMICAS E FISIOLÓGICAS}

As pessoas costumam dizer que os homens e as mulheres são diferentes "por fora" e "por dentro", isto é, na sua aparência física exterior e com relação a seus órgãos internos.

Uma das principais diferenças internas é que o homem é "inteiro" e a mulher não. Isso significa que ela possui na sua "barriga" um lugar vago, ou seja, não-ocupado por nenhum órgāo. Esse local "oco" no ventre da mulher destina-se a abrigar os filhos que ela vier a ter, durante a gestação, conforme explicam os itapuaenses: "A mulhé, o maquinismo da mulhé é deferente do home, porque eu acho que seja, porque por meio dela dá luz uma criança. tivé desintrapalhado tudo ali no ventre dela (...). Porque o home pode tê até os bofe, fígado, bobó, bucho, completamente tudo dentro do intestino dele (...). E que a mulhé só pode tê uma parte prum lado e pra outro por causa de podê construí uma criança, pra criança ali só pode tê aquele lugar reservado".

A outra diferença é que só a mulher possui um órgāo, rotulado em Itapuá como "mãe do corpo", "dona do corpo", ou "madre", localizado no seu "ventre" umbilical. Segundo os informantes, é a "madre" que comanda todo o "maquinismo" da mulher e, por isso, é considerada como o "essencial" do seu corpo.

Os outros brgãos do ventre da mulher, relacionados às funções femininas, são o "útere" (útero), o "orvalho" (ovário) e as "cordas", que, juntamente com a "madre", formam o seu "maquinismo".

Vejamos então, agora, os estados fisiológicos femininos e as idéias e práticas que os acompanham.

\section{MENSTRUAÇÃO: A "VISITA" QUE "APRISIONA"}

A menstruação é designada, em Itapuá, pelos nomes de "visita", "tempos", "incômodo" e "bode", embora não seja desconhecido o termo "menstruação".

A partir da menarca dá-se o afastamento compulsório da mulher dos domínios ditos masculinos (mar, porto, rios) ou ambíguos (mangal), e isto está socialmente ligado ao fato de que daí em diante ela passa a estar sujeita a uma série de perigos ou ameaças que

* Em ltapuá, o termo "ventre" só é empregado para referir-se à mulher. O homem só tem "barriga", mas a mulher, dentro desta, possui o ventre, onde se localizam os órgãos responsáveis pela reprodução. 
interditam, em última análise, a ultrapassagem de domínios que a sociedade reconhece como pertencentes ao homem.

Em Itapuá, a menstruaçāo é percebida como um estado intermediário entre a saúde e a doença, tendendo, entretanto, mais para a segunda, pois qualquer desobediência da mulher às interdições próprias dela produz sérios prejuízos à sua saúde.

$\mathrm{Na}$ verdade, todas as prescrições e proibições, neste contexto, denotam a procura de um ponto ideal, um meio-termo. Todo excesso deve ser evitado: "Muito frio e muito calor faz mar, tem que sê um ponto regular (...). É a chuva, o barro num pode pisá, é muito frio, o calor do forno (de farinha) (...)".

As interdiçōes também estāo ligadas às crenças relativas aos "humores" do corpo humano e à "síndrome quente-frio"".

Não $\varepsilon$ fácil para os itapuaenses definir os humores. Eles os relacionam à "pressăo" (quentura) do sangue, mas o que de fato afirmam é que o bem-estar físico da pessoa depende de ela estar com "bons humor", pois então mais dificilmente poderá ser atingida por uma doença.

Além disso, as proibições alimentares durante a menstrução dizem respeito a um contexto mais vasto, referente à reima dos alimentos. Nesse sistema, os alimentos são classificados como "reimosos" ou "mansos" (não reimosos) e relacionados a determinadas categorias de pessoas que se encontram em certos estados liminares (purga, xamanismo, luto, menstruação, puerpério, etc.). A palavra reima não é usada em Itapuá; fala-se apenas em alimento "reimoso" e "manso".

Os critérios utilizados para classificar os alimentos em reimosos ou mansos levam em conta três momentos: a) o alimento em si, antes de ser preparado para o consumo; b) o estado da pessoa que vai consumi-lo; e c) o modo de preparo do alimento.

De todo modo, porém, após o primeiro e o segundo momentos, o alimento é sempre potencialmente reimoso, pois, mesmo aquele mais manso pode tornar-se reimoso, casocertas regras importantes deixem de ser obedecidas na ocasiāo do seu preparo (ficar enfumacado, por exemplo).

No caso da mulher, a reima é de fundamental importância na classificação dos alimentos prescritos ou proibidos nos diversos estados de seu ciclo, no contexto das proibiçōes alimentares a eles ligadas.

Proibições e doenças de ordem natural. Durante a menstruação, como foi dito, a mulher está sujeita a ameaças de ordem natural e sobrenatural, que determinam proibições que ela deve cumprir. As proibições de ordem natural dizem respeito à ingestão de certos tipos de alimentos (isolados ou combinados entre si) e ao comportamento da mulher em determinadas situações.

Os alimentos considerados proibidos ("reimosos") para a mulher menstruada são, principalmente, os de origem vegetal e, neste grupo, as frutas em particular. Ela não ingere, enquanto dura ofluxo, os seguintes tipos ou "qualidades" de frutas: ácidas (limão, laranja, abacaxi, araçá, cupuaçú, bacuri, etc.), travosas (caju, taperebá, taramino, etc.) e gordurosas (abacate, piquiá, uxi, umari, etc.).

* O tema relativo à síndrome quente-frio já foi analisado por vários antropólogos. Fora do Brasil temos os estudos de Foster (1953), Currier (1966) e Logan (1973), entre outros. No Brasil, devem ser mencionados os estudos de lbañez-Novión (1974). Peirano (1975) e Brandão (1976), que anafisaram a sua ocorrência, respectivamente, em Sobradinho (DF), Icaraí (CE) e S. José de Mossâmedes (GO). Com relação a ltapuá. o tema é tratado mais amplamente em Motta-Maués (1976). 
A proibição das frutas ácidas, travosas e gordurosas relaciona-se também a conseqüências danosas para a mulher, sob a forma de "doenças do ventre", uma categoria de doenças que só atinge as mulheres, tais como a "suspensão", as "flores brancas" e a "mola".

Na suspensão, o sangue menstrual "sobe pra cabeça" e, segundo acreditam, a mulher pode ficar louca ou até mesmo morrer, se o tratamento seguido nesses casos não der certo: "Suspensão, a menstruação sobe, pronto, não desce, pode (...) tem mulhé que pode morrê doida, uma alta dor de cabeça, e haja remédio pra arriá, feliz dela se arriá, se arriá ela tá na boa, e se nāo arriá fica doida".

As frutas "gordurosas" provocam a chamada "flores brancas" ou "purgação": "Purgação é o mesmo escorrimento (corrimento), é a mesma flores branca, dá de extravagância, de não guardá a boca de comê certas coisas gorduroso, é que vem dá essa flor".

A outra proibição, neste contexto, é a que se refere à mistura de alimentos. A mulher menstruada não pode ingerir, numa mesma refeição, carne com peixe e/ou mariscos, a não ser que entre um alimento e outro ela tome uma certa quantidade de água ( 1 copo), "pra fazê a separação". De qualquer forma, é preferível evitar totalmente a mistura, cuja transgressão pode ameaçar uma gravidez futura através da doença rotulada de "mola" pelos itapuaenses.

As proibições não-alimentares da menstruação referem-se ao comportamento que a mulher deve assumir nessa situação, e se relacionam, principalmente, ao contexto da síndrome quente-frio.

Quando está nos "tempos", a mulher nāo pode tomar banho. No final, ela deve tomar um banho "cabeça e tudo", (de corpo inteiro) pois, se ela não molhar também a cabeça, não faz a "arriação", e o sangue retido subirá, causando-lhe uma "suspensão".

Outra interdição nesse contexto é a abstinência sexual, que é talvez a mais rigidamente observada, pois o próprio homem evita a mulher nesse perfodo. As explicaçōes para a proibição são que "€́ porcaria", ou que "faz mal para a mulher", porque ela está "aberta" e isso contribui para abri-la mais: "Eu acho que seja até uma porquidade, né, tem mulhé que diz que faz, eu nunca vi, mas ouço dizê, não tem respeito com nada, mas besteira é delas, né, porque o home faz a obrigação e a mulhé há de se defendê". Presentes aí as idéias universais(?) da poluição feminina e do comando masculino.

A partir do que foi visto até aqui, é bom lembrar que as ameaças de ordem natural a que fica exposta a mulher durante a menstruação constituem um importante fator ideológico do grupo, para justificar o comportamento ritualizado que se impõe nesse estado, contribuindo para restringir a sua atuação no sistema social. O mesmo se pode dizer com relação às ameaças e proibições de ordem sobrenatural, de que tratarei a seguir.

Proibições e doenças de ordem sobrenatural. As entidades que podem causar mal à mulher nos seus "tempos" são os "bichos" ou "encantados-do-fundo", que habitam ou frequientam o mangal, o porto, os rios e igarapés, locais que por isso devem ser evitados pela mulher naquela situação.

Entre os chamados "bichos-do-fundo" ou "encantados" estāo as oiaras e o boto, considerados os mais danosos para a mulher menstruada, sendo que o boto pode prejudić-la mesmo em qualquer ocasiāo* . Na menstruação, porém, ela atrai (sem saber) esses encantados.

* Não se trata de um boto comum e sim de um boto encantado. Maiores detalhes a respeito dos "encantados-do-fundo" em Itapuá se encontram em Maués (1990). 
As "oiaras" podem provocar uma doença chamada "corrente-do-fundo", isto é, ataques perídicos durante os quais a pessoa é "tomada" por elas e perde o controle sobre seus atos, ficando fora de si (em transe). Nesses casos, é necessária a intervenção de um pajé curador, para afastar a entidade, (já que socialmente a mulher não é aceita como xamã).

O boto só ataca mulheres, e mais, só no período que vai da menarca até a ocorrência da menopausa. Apresentando-se como um jovem bonito, sempre vestido de branco, o boto passa a namorar a mulher, até conseguir manter relações sexuais com ela. Quando isso acontece, o boto deve ser morto a bala, (o que sempre ocorre aliás), senão ele suga todo o seu sangue, através do ato sexual, e a mulher acaba morrendo anêmica ${ }^{*}$. Entretanto, a simples aproximação do animal pode provocar dores de cabeça e febre alta, a que exige a benzição de um pajé ou benzedor.

\section{A GRAVIDEZ: SENDO MULHER EM ITAPUÁ}

Para que a gravidez ocorra, segundo os itapuaenses, é necessário que a mulher se "junte" (pelo ato sexual) com um homem, a fim de que ele deposite nela o seu "micobri" ou "pingo" (sêmen): "Pra se gerá a criança, olhe, vai. vai daquele pingo, né, quando o home vai fazê a obrigação dele (copular) cum a mulhé, né, aquele pingo fica, aí vai se gerando (...)".

Embora acreditem que o sangue da mãe também ajuda no desenvolvimento da criança, todos costumam dizer que "a criança vem do pai". Como me dizia uma mulher: "Pra se formá uma criança, se gera do home, um micóbri, que aquilo (sêmen) é um micóbri, ele sai do home pra mulhé recebê, a mulhé recebe mas aquilo é feito do próprio home pra mulhé recebê, só recebe, agora o menino, a menina se gera do próprio sangue da mãe, mas aquele micóbri já foi do pai e junta com o sangue da mãe". Mais uma vez o modelo da hierarquia entre os sexos se faz presente, diminuindo e quase anulando o papel da mulher.

Contrastando com a menstruação e o puerpério, a única proibição que existe na gravidez é à mistura de carne com peixe e/ou mariscos, que mencionei no caso da menstruação, mas aí também o pai da criança fica suj̣cito ao mesmo preceito. Os itapuaenses acreditam que essa mistura pode provocar, durante a gravidez, uma doença que chamam de "mola". Ela ocasiona a formação de "bichos" no ventre da mulher, que podem "comer a criança" que está se formando, sendo mesmo muito difícil que a gestação chegue a bom termo, quando a mulher é atacada desse mal.

Uma das várias mulheres que dizem ter tido essa doença relatou-me assim sua experiência: "Ele nasceu (morto) de noite, depois que ele nasceu passei muito ruim, era de tempo: eu teve ele. aí a morragia (hemorragia) disse: agora é aqui. Chega me dava passamento, e a mina (grande quantidade) de bicho que eu botava, bicho grande, parece esse bicho que dá no mangar; eu pus uma coisa parece um abacate grande, uma senhora

* O tema do boto que se transforma em gente e seduz as multheres, muito disseminado por toda a Amazônia. é tratado com alguns detalhes, na literatura antropológica, por Galvão (1955) e Wagley (1957). Com relação à Itapuá, o assunto é abordado por Maués (1990). 
que era parteira disse que aquilo era o saco dos bicho, foro examiná tava cheio de bicho, de todo tamanho, parece assim uma arraia".

Embora a gravidez não acarrete praticamente perigo algum para a mulher (a não ser a "mola"), ela mesma pode representar uma ameaça para outras pessoas, na medida em que, nesse período, algumas mulheres se tornam "venenosas" ou "panemas", ocorrendo o mesmo, no caso do "veneno" apenas, em relação à menstruação. Na gravidez, porém, o fenômeno é mais acentuado e, portanto, mais perigoso.

O "veneno" da mulher é uma espécie de poder destruidor incontrolável de que ela fica possuída, que se manifesta no sentido de causar dano às plantas e aos animais. "Se ela pegá uma fruta aquela frutera morre; é sim senhora, se ela vai apanhá pimenta, a pimentera fica, chega fica só seca, e se ela enxergá uma cobra ela num morde, pode até pisá em cima, ela pode saí de cima, pode ir embora, que num acontece nada".

Além de venenosa, a mulher grávida pode transmitir "panema" para o pescador ou o caçador, se comer a sua "imbiara", (o peixe ou animal que ele pescou ou caçou). Isto não se dá em toda gravidez, podendo ocorrer em algumas gestações e em outras não.

Panema é uma espécie de estado de incapacidade em relação à atividade produtiva, que diferentemente do chamado azar, com o qual é às vezes comparada, é permanente enquanto dura o estado da pessoa empanemada (algo como estar "embruxado"). Analogicamente, um dos indicadores mais seguros de que uma mulher grávida está "panema" é a sua indisposição para executar suas tarefas diárias (os serviços da casa e da roça): "Dessas mulhé que fica mole, fica num sei como, aquela (...) já pode contá, ih! Uma panema das maió, e tem muitas que não, né, a mulhé fica até esperta, sadia", explicam os itapuaenses.

No que se refere, ainda, a esses poderes perigosos da mulher, justamente quando atualiza processos eminentemente naturais, pode-se dizer que isto reflete a propria percepção com relação a ela como uma categoria ambígua e ambivalente que, ao mesmo tempo em que dá origem a um novo ser (a criança), também ocasiona a morte de outros (plantas e animais). Creditar à mulher um poder destruidor, nesse momento, é como diminuir ou procurar anular, de certa forma, o outro tipo de poder, benéfico, que lhe é próprio - a sua fertilidade.

\section{O PARTO: UM RITUAL DE MULHERES ENTRE MULHERES}

O nascimento é marcado, em Itapuá, por um sofisticado desempenho ritual. Logo que começa o trabalho de parto, prepara-se um local que é designado com o nome de "lugar". Em um aposento reservado da casa. forra-se um canto no chão, com uma esteira de palha e alguns panos, para ali a mulher deitar para ter seu filho. Além da esteira é colocada uma vela de embarcação, (já usada), como uma espécie de forro, no teto do quarto, por cima do local onde ficarão deitadas a mãe e a criança, depois que esta nascer.

Além da "assistente" (parteira), outras três mulheres participam obrigatoriamente do ritual do nascimento, a "leiteira", a "tratadeira" e a "lavadeira", todas contratadas com bastante antecedência pela mulher, e escolhidas entre mulheres da própria localidade. 
A leiteira ("mãe-de-leite") amamenta o recém-nascido nos seus três primeiros dias de vida, pois, segundo os informantes, naquele período o leite da mãe é considerado "venenoso" - sua coloração amarelada indica isso. Há aí uma relação com a reima dos alimentos, pois os peixes que apresentam essa coloração sāo sempre muito reimosos.

A tratadeira, como diz o nome, é a mulher que vai "tratar" da que "descansou": substituí-la nas tarefas domésticas, que ela está impedida de executar, e cuidar, de modo especial, da parida, e juntamente com a leiteira, "se muda" para a casa dela nos primeiros dias.

A lavadeira é a encarregada, especialmente, de vir lavar a roupa da mãe e da criança que nasceu, separada das outras pessoas da casa.

A mulher de parto também se encontra vulnerável, como no caso da menstruação, a ameaças de ordem natural e sobrenatural. Os primeiros dizem respeito, principalmente, a doenças que possam atingi-la e lhe causar até a morte. Entre estas existem duas, consideradas mais graves: a "morragia" (hemorragia) e a possibilidade de o "parto subir" (para a cabeça).

A primeira, que pode ocorrer por ocasiāo do parto ou mais tarde, nos primeiros dias do resguardo, é sempre associada, pelos itapuaenses, com a "mola", a que já me referi antes. A outra doença (o parto subir para a cabeça) também pode acontecer durante o parto, ou nos primeiros dias do resguardo, sendo causada por um simples "susto", ou por um abalo emocional mais forte (morte de um parente, por exemplo).

Os perigos de ordem sobrenatural são desencadeados pelos "encantados", os "invisíveis", que estāo em toda parte, e para evitar que eles possam "malinar" com a mulher ou a criança recém-nascida é preciso prevenir-se; daí as defumações que se fazem nelas e, também, em suas roupas, tanto na hora do parto como durante os oito primeiros dias do resguardo.

Por outro lado, a propria mulher que está de parto representa um perigo dessa natureza, através das exsudações do seu corpo. Em razão disso, as duas pessoas que lidam mais intimamente com ela, seja diretamente (assistente), ou através de suas roupas (lavadeira), tomam precauções (esfregando alho ou cachaça nos braços) para evitar que sejam atingidos por algum mal por terem pegado "naquelas coisas do parto da mulher".

\section{O "RESGUARDO" PÓS-PARTO: PERIGOS, CRENÇAS E RITUAIS}

O período do resguardo pós-parto é considerado, em Itapuá, como extremamente perigoso para a mulher. As pessoas costumam dizer que, até se completarem os quarenta dias posteriores ao parto, a mulher está "com o pé na sepultura". Uma série de prescriçōes e proibições de vários tipos acompanham essa fase, e podem ser vistos como os procedimentos necessários para que ela seja ultrapassada com êxito.

Durante o resguardo existem dois dias que são particularmente perigosos para a mulher, e por isso devem ser mais "guardados" por ela: são o sétimo e o quadragésimo, que exigem reclusão absoluta. 
A explicação que as pessoas dão para esse tipo de comportamento é a seguinte: desde o dia do parto, a "sepultura" da mulher está aberta e, quando se completam os quarenta dias, ela fecha e, então, a mulher está livre. Além disso, é também nesse dia que o corpo da mulher se "fecha", depois de ter estado "aberto" desde a gestação, daí a necessidade de sua quase imobilidade e reclusão. Por tudo isso, qualquer descuido da parte dela, naquela ocasião, pode ser motivo, segundo acreditam, de sérios transtornos e até mesmo a morte.

O resguardo realmente năo termina ao fim dos quarenta dias após o parto, pois, no que concerne às prescrições alimentares e certas atividades, esse período se alarga até um ano ap6s o nascimento da criança.

\section{AS PRESCRIÇÕES PRÓPRIAS DO RESGUARDO: PARA NÃO FICAR "ESTRAGADA"}

As itapuaenses costumam dizer que as mulheres da cidade ficam "estragadas" porque nāo têm resguardo.

Em Itapuá, as prescrições próprias do resguardo dizem respeito aos alimentos e aos comportamentos que devem ser evitados ou seguidos pela mulher durante os cinco períodos que o compõem. O primeiro compreende os sete dias, a contar daquele em que ocorreu o parto; o segundo vai do $8^{2}$ até o $40^{2}$ dia; o terceiro, do $41^{\circ}$ dia até o $3^{\circ}$ mês; o quarto, do $4^{\circ}$ até $06^{\circ}$ mês; e, finalmente, o quinto, vai do $7^{\circ}$ mês até se completar um ano aṕs o parto. Esses períodos podem ser reunidos em dois grupos, de acordo com a maior ou menor rigidez com que se aplicam as proibições alimentares.

Assim, nos três primeiros períodos (até o $3^{\circ}$ mês), são discriminados estritamente os alimentos permitidos à mulher, sendo todos os outros proibidos; nos dois últimos (do $4^{\circ}$ mês a 1 ano), determina-se apenas o que ela não pode comer, sendo permitidos os demais alimentos.

Durante o primeiro período do resguardo, a mulher recebe uma alimentação especial, que contrasta tanto no que se refere ao número de refeições diárias, como à quantidade e aos tipos de alimentos, com o que é consumido habitualmente pela população de Itapuá. Logo cedo, ela toma café com pão, ou bolachas e manteiga; às nove horas, mais ou menos, vem a "merenda" da manhã, que consta de uma sopa de galinha com macarrão ou arroz e pão; no almoço, é galinha cozida, servida com macarrão, arroz e bastante farinha de mandioca; à tarde, outra merenda, constando de café como é servido de manhã cedo; o jantar é igual ao almoço e, antes de dormir, torna a tomar café com pāo ou bolachas. Geralmente a mulher consome uma galinha por dia, nessa primeira semana, sendo a metade em cada parte do dia.

Esses são os únicos alimentos permitidos para o consumo da mulher neste primeiro período, sendo todos os outros proibidos.

Quanto aos comportamentos próprios dessa fase, ela pode amamentar seu filho, embora sem deixar a rede (ou cama) em que fica em uma quase total imobilidade, pois até mesmo as refeições ela faz deitada. Só the é permitido levantar-se para satisfazer suas necessidades fisiologicas, o que é feito sem deixar o aposento em que se encontra reclusa. 
Além dessas atividades, tudo o mais é proibido para a mulher, embora os informantes acentuem, sobretudo, dois tipos de proibição: sair do quarto e manter relações sexuais.

Dos oito até se completarem os quarenta dias após o parto ( $2^{2}$ período do resguardo), a dieta da mulher já inclui alimentos que ela não consumia antes: "peixinho bom" e carne bovina.

A categoria "peixinho bom" inclui o peixe considerado não-reimoso, o que significa, neste contexto, peixe pequeno, não-gordo e não-capturado com redes de náilon ou plástico, passado pelo processo de salga, pois o sal é um dos elementos que "cortam" (diminuem) a reima e em seguida é moqueado, ou seja, assado no calor do braseiro do fogão, sobre talas de madeira. Depois é lavado e cozido em bastante água, para servir de alimento à mulher. Além do peixe, ela também pode comer carne bovina, neste período, tanto o "jabá" (charque), como a carne fresca, submetida à salga como o peixe, e preparada de modo igual.

Quanto aos comportamentos da mulher neste período, quando se completam os sete dias após o parto, ela deixa o quarto e já começa a retomar aos poucos as suas obrigações domésticas, embora ainda não possa sair de casa. Essas obrigaçōes incluem o preparo dos alimentos e os cuidados da casa, do marido e dos filhos. Entretanto, ela não pode ainda fazer serviços considerados "pesados", e carregar qualquer coisa de mais peso, inclusive os filhos pequenos (com exceção do recém-nascido).

Além dessas, uma proibição que deve ser rigorosamente mantida pela mulher é a que se refere às relaçōes sexuais, que devern ser suspensas até que ela tenha "quarentado" (ultrapassado os $\mathbf{4 0}$ dias). A continência sexual nesse período, mesmo que já tenha cessado o fluxo sangüíneo, é justificada pelos itapuaenses como sendo necessária à mulher, que está ainda "aberta" e, por isso, não deve fazer algo que contribua para mantê-la assim; por essa razão, o ato sexual é aconselhado, como já vimos, durante a gravidez. As mulheres costumam relatar casos em que outras saíram do resguardo grávidas (sinal evidente de que não cumpriram a proibição), condenando sempre o homem que não "respeitou" o resguardo de sua mulher".

No terceiro período do resguardo pós-parto (do $4^{\circ}$ dia ao $3^{\circ}$ mês), as proibições alimentares ainda se mantêm bastante rigorosas. A partir dos quarenta dias é permitido à mulher o consumo do peixe fresco, desde que não seja reimoso, e do caranguejo, este com uma restrição: não ser de uma espécie particular chamada "manicujá", considerada "venenosa", por ter as duas "unhas" grandes de um só tamanho ${ }^{* *}$.

Devido ao rigor das proibições alimentares que acompanham estes três primeiros períodos do resguardo pos-parto, chega mesmo a ser comum que as mulheres se alimentem, as vezes, apenas de mingau de farinha de mandioca, quando há falta de alimentos que elas possam consumir.

Entretanto, depois de "quarentar", a partir, portanto, do $3^{\circ}$ período, a mulher pode enfim sair de casa e retomar suas atividades normais, inclusive o trabalho nas roças. Pode, a partir dá, manter relações sexuais. Não obstante, ela deve evitar ainda tarefas que exijam

* A "condenaçăo" atinge apenas o homem, pois a mulher deve sempre se submeter aos desejos do marido, nảo tendo, portanto, "culpa" no caso.

* Devo dizer que, no caranguejo comum, uma das unhas grandes é sempre maior do que a outra. Neste ponto vale lembrar a observação de Mary Douglas (1966), no capítulo de seu livro sobre as "abominações do Levítico": "em geral, o princípio subjacente da pureza dos animais é que eles sejam totalmente conformes à sua classe. São impurezas as espécies que sāo membros imperfeitos de suas classes ou cuja própria classe confunde o esquema geral do mundo" (tradução de Mônica Siqueira Leite de Barros e Zilda Zakia Pinto; Douglas (1976:72). 
um esforço maior, principalmente carregar coisas muito pesadas (cestos de mandioca, por exemplo).

No que diz respeito aos dois últimos períodos, as proibiçōes diminuem sensivelmente, sendo que apenas ainda se mantêm as referentes aos alimentos.

O quarto período, que vai do $4^{\circ}$ ao $6^{\circ}$ mês, inclui como proibiçōes alimentares as frutas ácidas e gordurosas. Além dessas frutas, os demais alimentos proibidos são a carne de porco e dois peixes referidos como muito reimosos, o cação e o pacamon. A partir desse período a mulher já pode assumir todas as suas atividades normais, não havendo mais restrição alguma, no tocante ao comportamento considerado como próprio do seu sexo.

Finalmente, o $5^{\circ}$ e o último período do resguardo (do $7^{\circ}$ mês até 1 ano) conserva, apenas, as proibições alimentares referentes ao consumo da carne de porco e dos peixes cação e pacamon.

Deve ser lembrado, porém, que, como a partir do $3^{\circ}$ período do resguardo, a mulher já pode manter relaçōes sexuais, é muito provável que fique grávida novamente, antes de se completar um ano apos o parto. Se isto acontecer, cessam todas as proibições referentes ao resguardo.

\section{A MENOPAUSA: "VIRANDO HOMEM" EM ITAPUÁ}

De muito menor expressividade no que diz respeito a desempenhos rituais do que a menarca ou a menstruação de modo geral, apesar de representar uma mudança bastante acentuada na mulher (do ponto de vista biológico), a menopausa possui, em Itapuá, uma importância social muito grande.

A ocorrência desse processo não é marcada por nenhum desempenho especial. Nenhuma prescrição ou proibição assinala para a mulher essa fase de sua vida, pelo contrário, a menopausa é ansiosamente aguardada e recebida com muita alegria, pois significa justamente o fim das restrições que lhe foram impostas desde que chegou a sua primeira "visita". Como me dizia uma mulher: "Ah! Mas eu fiquei foi alegre, porque às vez queria ir pegá um caranguejo, ficava presa, nāo podia ir no mangal; e eu tinha uma raiva, tá lavando roupa todos os mês, a gente qué fazê uma viage, uma coisa aperriada, Deus o livre".

As mulheres não referem qualquer sintoma que acompanhe o final de seu período fértil, a não ser a irregularidade do fluxo, até a sua cessação total. A idéia que existe sobre a época da ocorrência da menopausa é de que, quanto mais filhos a mulher teve, mais cedo chegará esse período para ela: "A gente quando tem muitos filho, assim de oito, nove, doze filho, cedo pára, e quando só tem pouco filho sempre custa a terminá". Essa idéia está associada para elas à perda maior de sangue que ocorre com as multíparas em relação às outras que tiveram menos filhos: "Porque, sabe, quando a gente tem filho é uma coisa que, quando vem, vem mesmo (...)" (referindo-se ao sangue expelido durante e após o parto) ${ }^{*}$.

* Devo dizer que, para as mulheres de Itapuá, ter poucos filhos significa uma prole de pelo menos umas cinco crianças, uma vez que a maioria delas costuma ter sempre mais de dez filhos, sendo muito mais comum os casos en que esse número sobe para quinze ou mais. Entretanto, como a mortalidade infantil é muito grande, geralmente esse número fica reduzido à metade. Aliás, era sempre motivo de estranheza para minhas informantes o fato de eu só ter três filhas, principalmente por já estar casada há vários anos. 
O término do período fértil da mulher, em Itapuá, ao marcar justamente a abolição de todas as restrições que a ocorrência do seu início (a menarca) representou para ela, realiza, de alguma forma, o retorno a uma situação anterior, na qual as mesmas restriçōes ainda não existiam. É possível dizer mesmo que o caráter indefinido da sexualidade da menina, de um lado, e a perda da fertilidade da mulher idosa, de outro, promove, num plano simbólico, mas que se reflete também, em termos do comportamento, a aproximaçāo dessas duas categorias de mulheres, na medida em que a ambas é permitida uma intromissão em domínios considerados como masculinos.

$\mathrm{Na}$ verdade, todas as ameaças ou perigos, e as prescrições e proibições que os processos naturais acarretam, são impostos à mulher apenas no período de sua vida que decorre entre a menarca e o climatério, portanto, enquanto ela é definida, sem restrição alguma, como mulher. Antes da ocorrência da menarca, a mulher, como menina ainda, $\epsilon$ por assim dizer "assexuada", no sentido de não ser identificada integralmente a um ou outro sexo.

A própria classificação utilizada pelos itapuaenses mostra que não se estabelecem diferenças entre as crianças de ambos os sexos, ao incluírem todas numa mesma categoria, que $e$ designada pelo termo "canalha". A separação só se realiza quando a menina se torna "moça", e tem de abandonar o grupo heterogêneo de que fazia parte.

Por outro lado, quando a mulher deixa de ser "visitada" (menstruada) diz-se que ela "já é homem", o que é bem traduzido pelas próprias mulheres ao comentarem a sua chegada em alguma delas: "É, nós brinquemo assim. Às vez ali a comadre Lúcia, eu digo assim, tu já é home, não? Ela diz: tu também já é". Embora isso seja sempre dito em tom de brincadeira entre as mulheres, indica, também, através da categoria verbal utilizada, uma redefinição da mulher no sentido de sua atuação social.

\section{UM "LUGAR" PARA A MULHER}

O modelo de sociedade dos itapuaenses configura um mundo em perfeito equilíbrio, o que, por sua vez, depende do equilßßrio, das três ordens que o compōem. Nesse modelo, qualquer excesso, desordem, confusão, não pode ser permitido. Todas as fronteiras são muito bem demarcadas e a sua ultrapassagem só é feita com segurança.

Designar, neste sentido, um lugar à parte para as mulheres, significa interditar-lhes o trânsito em outros espaços (não só sociais, mas físicos) à base de uma série interminável de prescriçōes e proibiçōes que vigoram desde que elas "ficam moças" (com a ocorrência da menarca) e são permanentemente seguidas até quando "viram homem" (com a chegada da menopausa).

Tais interdições, como vimos. estão vinculadas a uma série de concepções e práticas médicas, e rituais que relevam de crenças secularmente partilhadas de uma forma particular de conhecimento acerca do funcionamento do organismo feminino, de um conjunto complexo de hábitos e ideologias alimentares e das representaçōes sobre os papéis de gênero.

Nesse mundo se movem as mulheres - nosso sujeito por excelência neste trabalho -, que partilham com os homens de sua sociedade a adesão ao modelo que as exclui. Terrível 
adesão essa, pois percebidas nele como ambíguas, transitantes, perigosas, ameaçadoras da ordem, portanto, também se percebem assim e, como tal, incorporam e atualizam a imagem negativa e diminuida que o espelho social reflete.

Imagem e exclusão tão exemplarmente retratadas no ritual do parto, através do "lugar" que se prepara para a mulher parir - no chão (embaixo, portanto), num canto do quarto (fechado) forrado com uma esteira e panos, tendo no teto (em cima, portanto) dominando todo o ambiente, uma vela de embarcação, símbolo masculino por excelência, numa sociedade de pesca. No ritual, pedagogicamente, a sociedade sinaliza a cada sexo o papel e o espaço que lhes destina. 


\section{REFERÊNCIAS BIBLIOGRÁFICAS}

BRANDÃO, C. (1976). Mossâmedes: Crenças e Costumes de Comida. In: Sociedades Rurais do Mato Grosso Goiano. Universidade Federal de Goiás.

CURRIER, R. (1966). The Hot-Cold Syndrome and Symbolic Balance in Mexican and SpanishAmerican Folk Medicine. Ethnology 5 (3): 251-263.

DOUGLAS, M. (1966). Purity and Danger: An Analysis of Concepts of Pollution and Taboo. Routledge and Kegan Paul, London.

FOSTER, G. M. (1953). Relationships between Spanish and Spanish-American Folk Medicine. Journal of American Folklore 66: 201-217.

GALVÃO, E. (1955). Santos e Visagens, Brasiliana 184, São Paulo, Editora Nacional.

IBAÑEZ-NOVIÓN. M. A. (1974). El Cuerpo Humano, la Enfermedad y su Representacion. Dissertação inédita de mestrado. Universidade Federal do Rio de Janeiro.

LEACH, E. (1964). Antropological Aspects of Language: Animal Categories and Verbal abuse. In: Vogt and Lessa (Eds.): Reader in Comparative Religion. Harper and Row.

LEAL, O. F. (1993). Sangue, Fertilidade e Práticas Contraceptuais. I Encontro Nacional de Antropologia Médica. Salvador (xerox).

LOGAN. M. N. (1973). Humoral Medicine in Guatemala and Peasant Acceptance of Modern Medicine. Human Organization 32 (4): 385-395.

MAUÉS, R. H. (1990). A Ilha Encantada: Medicina e Xamanismo numa Comunidade de Pescadores. Belém. Editora da Universidade, UFPa. (Coleção Igarapé).

MOTTA-MAUÉS, M. A. (1993). "Trabalhadeiras" e "Camarados": Relaçōes de gênero, ritualizaçāo e simbolismo numa comunidade amazônica. Belém, Editora da Universidade, UFPa (Coleção Igarapé).

MOTTA-MAUÉS, M. A \& MAUÉS, R. H. (1980). O Folclore da Alimentação: Tabus Alimentares da Amazônia. Belém. Ed. Falângola.

PEIRANO, M. G. S. (1975). Proibições Alimentares numa Comunidade de Pescadores. Dissertação inédita de mestrado. Universidade de Brasília.

SAPIR, D. (1970). Kujaama: Symbolic Separation among the Diola-Fogni. American Antrhopologist 56:1330-1348.

VAN GENNEP, A. (1960). The Rites of Passage. The University of Chicago Press, Chicago.

WAGLEY, C. (1957). Uma Comunidade Amazônica. Brasiliana 190. São Paulo, Editora Nacional. 



\title{
SANGUE, FERTILIDADE E PRÁTICAS CONTRACEPTIVAS*
}

\author{
ONDINA FACHEL LEAL.
}

Este trabalho parte da evidência etnográfica recorrente em nossas pesquisas, de que mulheres de classes populares no Sul do Brasil entendem que o seu período fértil se sobrepõe, ou está imediatamente vinculado, ao período menstrual. Em primeiro lugar, comento estes dados e busco entender a lógica que ordena esta representação a respeito do corpo, de seus fluidos e da concepção. Segundo, abordo as consequiências que este entendimento tem na escolha e no uso de métodos contraceptivos. Minha hipótese é de que estas noções a respeito do corpo - que identificam sangue com fertilidade, fazem uma homologia entre sangue e esperma e indicam crenças a respeito do estado do corpo - são bastante generalizadas e não se restringem ao universo do grupo pesquisado.

Os dados em que me baseio advêm de três fontes:

1. Material etnográfico por mim coletado em uma região rural do sul do Rio Grande do Sul, fronteira Brasil-Uruguai** ${ }^{*}$, no trabalho de Victora com mulheres de classe popular na região metropolitana de Porto Alegre ${ }^{* * *}$.

* Trabalho apresentado na Sessão La Antropologia en la Investigacion Sociodemográfica, do XIII Congresso Internacional de Ciências Antropológicas e Etnológicas, Cidade do México, 29 julho a 5 de agosto 1993. $O$ título da primeira versão em inglês deste trabalho era The Magic and the Unmagic of Contraceptive Practices".

** Leal, Ondina Fachel - The Gauchos: Male Culture and Identity in the Pampas. Phd Dissertation in Anthropology. University of California, Berkeley, 1989 (Trabalho a ser publicado pela University of California Press.) Dados especificos a respeito de menstruação e fertilidade, embora não apresentados neste trabalho, foram coletados durante esta pesquisa de campo.

*** Victoria, Ceres - Mulher, Sexualidade e Reproduçäo: Representaçōes do Corpo em uma Vila de Classes Populares em Porto Alegre. Dissertaçāo de mestrado em Antropologia, Programa de Pos-Graduação em Antropologia Social, Universidade Federal do Rio Grande do Sul, 1991. 
2. Do material do folclore do Rio Grande do Sul, no que se refere a crenças e práticas sobre contracepção, procedimentos abortivos e parto, do acervo do Banco de Dados Etnográficos do PPGAS/UFRGS*.

3. Material etnográfico de pesquisa em andamento sobre práticas reprodutivas e contraceptivas, sob suporte da Organizaçāo Mundial de Saúde, em quatro vilas de classes populares atendidas por Serviços Comunitários de Saúde na cidade de Porto Alegre** .

Estou, portanto, lidando com dois tipos de dados no que se refere ao universo pesquisado: pesquisa etnográfica em área rural e dados mais gerais de material do folclore, que se refere sobretudo a populações rurais; e dados etnográficos que se referem a populações urbanas, de baixa-renda, moradoras de favela, mas que têm a peculiaridade de serem atendidas por postos de saúde comunitários, ou seja, uma população que tem acesso fácil e continuado aos serviços médicos orientados, tanto à prevenção quanto à cura.

É importante ressaltar que o foco deste trabalho é o entendimento sobre reprodução de pessoas que vivem em uma área urbana e que embora vivendo em condições socioeconômicas extremamente precárias, têm acesso a serviços médicos efetivos, a programas de planejamento familiar, a diferentes métodos contraceptivos de forma gratuita, e acesso à informação veiculada pelos meios de comunicação em geral. Dados referentes à região rural, crenças e procedimentos a respeito de reproduçāo, contracepção e parto serão tomados aqui apenas de forma a auxiliar o entendimento daquilo que é vigente no meio urbano.

Situa-se aqui a problemática desta pesquisa. Identifica-se a evidência de uma representação a respeito do período fértil feminino que implica determinadas práticas reprodutivas e contraceptivas equivocadas (se pensarmos em termos da efiććcía das estratégias de medicalização). Classificar estas noções como ignorância, falta de informação ou resquícios de uma cultura tradicional (survival) não nos levam a lugar algum. Sobretudo, porque não se trata, de forma alguma, de ignorância, no sentido da falta da informação. As informações a respeito de contracepção, como foi dito, existem, são massivamente veiculadas, vários dos entrevistados inclusive já participaram de orientações sobre "planejamento familiar" ou grupos pré-natal que são constantemente oferecidos pelos postos de saúde locais. Neste sentido, as questões que se colocam no âmbito da antropologia médica são muito mais complexas: não se trata de produzir mais informação ou veiculá-la por outros canais (a legitimidade do médico nāo está em jogo), ou de dar à população acesso efetivo a diferentes métodos contraceptivos, uma vez que, de um modo geral, estes métodos já são disponíveis. O que se faz necessário é buscar a lógica que ordena tais representações a respeito do corpo e da reprodução.

* O Banco de Dados Etnográficos é um acervo informatizado, com uma base de dados específica, com material sobre medicina popular. A fonte deste material é seleção de estudos monográficos do Instituto Gaúcho de Folclore. O material original foi coletado em diversas regiōes do Rio Grande do Sul, entre 1970 e 1980. O Banco de Dados é do Laboratório de Antropologia Social do Programa de Antropologia Social, da Universidade Federal do Rio Grande do Sul.

** Pesquisa por mim coordenada, intitulada Body, Sexuality and Reproduction: A Study of Social Representations. Project 91378 BSDA Brazil. Special Programme of Research, Development and Research Training in Humas Reproduction, World Health Organization. 
Trata-se de percebermos a autonomia das culturas populares no que se refere aos modos de significação. A noção de matrizes culturais, como mediações capazes de ressemantizar e reordenar elementos culturais produzidos por outro grupo, $e$ indispensáve! quando buscamos entender a dissonância entre discurso médico, ou da mídia em geral, no que se refere a práticas contraceptivas e às classes populares. $O$ discurso médico, embora presente e disseminado na população em estudo, não $E$ identificado como uma única possibilidade de explicação de processos como dores, sintomas, e o que é nosso foco aqui, a reprodução humana. Elementos são tomados do discurso médico, mas são tornados coerentes a partir de um referencial englobante, norteador de práticas cotidianas, que envolve uma visão de mundo e todo um sistema de representações sociais a respeito do corpo. Propostas médicas, sobretudo no que se refere à contracepção, permanecem subalternas a este sistema de representações peculiar à cultura popular.

Em uma experiência de pesquisa anterior, o fato de que as mulheres pensavam seu período fértil associado de alguma forma à menstruação por razōes que vinculavam diretamente a noção de fertilidade a sangue, em seus procedimentos mágicos de cura ou de evitaçăo de males, pode ser tomado apenas como um indício da veracidade de algumas concepções, já clássicas na antropologia, no que diz respeito à equivalência simbólica entre sangue e esperma. Não havia dados suficientes para percebermos a evidência disto, enquanto parte de um corpo mais coerente de concep̧̧ões norteadoras de práticas reprodutivas ou contraceptivas. De que forma exatamente se dava a associação entre fertilidade e sangue permaneceu como problema, sobretudo porque nāo se centravam nesta problemática, naquele momento, minhas preocupaç̋̄es de pesquisa.

Já na pesquisa de Victora (1991) é apresentada uma série de dados neste sentido. Para Victora, a noção de que o período fértil coincide com o período menstrual, ou de que a fecundação é possível nos dias imediatamente anteriores e/ou imediatamente posteriores ao período menstrual, aparece como recorrente entre suas informantes. Victora, que está trabalhando com um universo feminino, aborda esta peculiar percep̧̧ão da fertilidade a partir de desenhos do corpo, onde é solicitado que elas desenhem o aparelho reprodutor feminino e falem como se dá a reproduçāo. Seu trabalho indica que as mulheres percebem seus corpos como únicos, singulares, "como um domínio particular de significaçð̄es". Neste sentido, "o período fértil de cada mulher é identificado como um funcionamento particular do seu corpo" e concluí que, nesta situaçāo, o sangue menstrual é emblemático da condiçāo de fecundidade" (Victora, 1991:178-9) ${ }^{*}$.

A partir do trabalho etnográfico de Victora foi possível formular como hipótese a equaçāo de que a fertilidade e o sangue menstrual nas representações populares estão intimamente associados, em termos de possibilidade de concepção. Trabalhando com o mesmo tipo de populaçąo (urbana, baixa-renda, atendida por serviços públicos de saúde), mas ampliando significativamente em número este universo, e não o restrigindo a um

- Para a noção de matrizes culturais ver Martin-Barbero (1987). A este respeito, a discussão apresentada por Boltanski (1984) segue a mesma linha de argumentação. Sobre modalidades da reinterpretaçẵo do discurso médico no que se refere à populaçăo. que é centro de nossa análise, ver Knauth (1991).

** Sobre a representação de corpo como único onde a dor, o prazer $e$ as demais sensaçães experimentadas por aquele corpo seråo balizadoras e determinantes do conhecimento a respeito daquele corpo individual, ver também Boltanski (1979), Loyola (1979), Duarte (1988). 
grupo feminino, pode-se observar exatamente a mesma configuração. Embora a pesquisa esteja ainda em andamento, a redundância dos dados no que se refere ao entendimento de quando é o momento em que "a mulher tem mais risco de pegar filho", surpreende. Nossa hipótese inicial indicava que esta seria uma das concepções a respeito de fertilidade existentes neste universo. No entanto, o que estamos constatando é a massiva homogeneidade no entendimento de que é exatamente o período menstrual o mais propício à concepção".

Quando solicitados a falar sobre o momento mais propício para que a fecundidade ocorra, cerca de $90 \%$ dos entrevistados fazem uma associação direta com o período menstrual, modificando-se apenas a especificidade das datas:

\section{"Acho que o mais arriscado mesmo é três dias depois da menstruação."}

"Três dias antes até três dias depois pơde pegar filho."

"Logo depois de vir as regras, quando o sangue ainda não secou todo."

"Até sete dias depois pode pegar filho."

"Assim que sair tudo, imediatamente depois da menstruação."

No andamento da entrevista (trata-se de entrevistas com vários encontros), quando retomamos a questão e perguntamos para aqueles que indicaram como fértil outro período que não o menstrual, se acreditam que a mulher pode engravidar também durante o período menstrual, a resposta é sim (embora seja este um período de evitação de relação sexual). Temos então praticamente uma unanimidade de respostas, tanto masculinas quanto femininas, quanto à possibilidade de fecundação, ainda que não seja este o período indicado como de "maior risco".

A proximidade com o período menstrual, através de uma representação mais ou menos generalizada, em que o corpo se abre para deixar sair o fluxo e depois volta a se fechar, é sempre indicada como um período fértil, perigoso, propício à procriação. Em concordância com isto, datas e números são sempre apresentados, mas nos parece manipulados, porque os entrevistados se sentem testados e buscam preencher aquilo que supōem como expectativa do entrevistador ("a data da tabela", "a data que o postinho ensina"). Nesta manipulação de números, o número três aparece mais ou menos de forma constante como algo significativo. Sete parece ser também um número chave. Outras datas são apresentadas como informações complementares, a data que the foi ensinada por exemplo no posto de saúde, ou que o informante toma como tendo sido a informação dada, porque de qualquer maneira uma data como "três dias antes e três dias depois do décimo quarto dia, contado a partir do primeiro dia do período menstrual" thes parece suficientemente

Os dados apurados referem-se a um universo de 50 casos: 40 mulheres, 10 homens, em idade reprodutiva. O total da amostra prevista é de 100 casos masculinos e 100 casos femininos. Trata-se de entrevistas e roteiro de observaçōes, de orientação etnográfica. Cada entrevista dura cerca de 10 horas e dá-se em pelo menos três encontros. (Project 91378 BSDA Brazil, World Health Organization). Ver nota 4. 
arbitrária e ilógica. Neste caso, associam-se a este período outras datas, estas sim comprovadamente perigosas:

"O médico disse que a mulher fica fértil no oitavo dia depois da menstruação, mas não é bem assim, depende da mulher, tem mulher que fica grávida quando menstrua."

"No $14^{\circ}$ dia depois da menstruação ou três dias antes ou três dias depois."

O número sete também aperece como um número chave. Razōes simbólicas para a associação com estes números, e não outros, talvez valham a pena ser investigadas, mas não será nosso objetivo aqui, elas podem fazer parte do discurso popular (e até mesmo do discurso médico). Mas neste caso, três e sete, não se trata de números mágicos, mas indicam uma conexão clara com o discurso médico: "três dias antes e três dias depois" mais "o dia perigoso" (perigoso sendo também uma expressão empregada pelos médicos), somam sete dias perigosos. A recomendação é repetida, há uma manipulação de exatamente os mesmos números. O que é tomado como referência é também a data da menstruação, mas há um deslocamento de datas. Além disto, sete é também o número de dias indicado pelos médicos para um "descanso", depois de vinte e um dias para quem toma contraceptivos orais. Neste caso, a data coincide com o período menstrual. Sete é ainda o número identificado com receitas médicas para uso de antibióticos.

A data do período menstrual (do primeiro dia do período menstrual) é também manipulada pelo médico para calcular o período gestacional. Na percepção popular, este fato pode ser tomado como uma indicação, não totalmente equivocada, da relação entre menstruaçāo e fecundação. Em qualquer serviço pré-natal, a data "do primeiro dia do último período menstrual" é uma data constantemente referida pelo médico e tomada como significativa para estimar a data de fecundação e a data provável do nascimento da criança.

Mesmo quando os ensinamentos do posto de saúde são repetidos com exatidão (na maioria das vezes a informação sofre uma reinterpretação peculiar), a informação médica é relativizada e tomam-se outros referenciais como mais significativos e capazes de ordenar a lógica da reprodução, identificando, ao final, fertilidade com menstruação:

"Tem a ereção, sai o esperma que vai se juntar com o óvulo no útero e aí começa a fecundação. Mas só no periodo fértil que é assim: cada mês a mulher está fértil por 24 horas num dia certo, mas depende da mulher. Os livros dizem que o periodo fértil da mulher é sete dias antes e sete dias depois da menstruação, mas eu não acredito. Minha mulher ficou grávida menstruada."

Gravidez é sempre tomada como um risco, um evento que pode vir a ocorrer ou não, e está sempre sujeito a um universo de possibilidades aleatórias. Em relação a esta idéia de risco, não é casual o termo pegar filho, que é a mesma expressão usada para ser contaminado por uma doença ou estar submetido a uma aflição: pegar uma doença. A fecundação é uma forma de contágio onde fluidos se encontram. A substância feminina, por excelência, $́$ o sangue, em analogia direta com a substância fértil masculina, que é o 
sêmen. Um de nossos informantes usava inclusive o termo sêmen da mulher, ao referir-se à "substância produzida nas trompas". A relação sexual é representada como um momento onde a troca de fluidos corporais ocorre. Trata-se essencialmente de uma relação social onde se dá uma troca, fluidos corporais são substâncias transmissoras daquilo que tanto pode ser poluído, quanto pode ser vida, emoções, substâncias morais. A homologia entre sangue menstrual e o sêmen, onde - enquanto fluido corporal - o fluxo menstrual está para a mulher assim como o sêmen está para o homem, enquanto condutores de fertilidade, é um tema bastante difundido na antropologia, como foi referido anteriormente ${ }^{*}$.

Uma série de dados mais gerais, que identifico como um sistema de crenças disseminado e englobante, indica a associação direta entre fluxo menstrual e fertilidade, à medida que ambos os processos são pensados como estados do corpo, estados úmidos e quentes, e como tal, propensos à procriação. Uma prática de resguardo menstrual extremamente difundida entre mulheres de classes populares é a de que a cabeça não deve ser lavada durante a menstrução:

"Senão o sangue pode subir para a cabeça e a mulher fica louca."

"Se tomar banho frio e lavar a cabeça o sangue sobe para a cabeça em vez de descer."

"Se se molhar, a água pode cortar o sangue, corta a menstruaçāo."

Nesta equação simbólica, o sangue é classificado como quente e a água como fria. Como indica Victora (1991:121), estas práticas de resguardo são exatamente as mesmas acionadas durante o sangramento pós-parto e pós-aborto. Em suma, seria difícil pensar este sangue como de outra natureza, como aquela de um fluido vital construtor do próprio feto. Indica uma informante:

"A menstruação que vem depois do parto vem com cheiro forte. E que fica nove meses parada."

Encontramos também representações da placenta e da própria gravidez como uma espécie de coágulo, um sangue adensado, solidificado ${ }^{*}$

"Depois de nove meses o sangue que se transformou em um enorme coágulo se desfaz."

A lógica que rege a elaboração dos chás abortivos ou dos chás para evitar a gravidez (chapueradas) é exatamente da mesma ordem. É interessante notar que, de um modo geral, não há uma distinção entre contracepção e aborto, a própria noção de prevenção não se faz presente no domínio da reprodução: pode-se desfazer apenas aquilo que está feito. O sangue que conforma o feto é o sangue que, não tendo ocorrido fecundação, seria fluido menstrual.

* Neste sentido, ver Lévi-Strauss (1982), Duarte (1981), Victora (1991), entre outros.

* Este dado é de uma pesquisa etnografica em andamento. de Jaqueline Ferreira, sobre Sintomas, Fluidos $e$ Sensações, em uma vila popular da cidade de Porto Alegre. Esta pesquisa é parte de sua dissertação de mestrado junto ao Programa de Pós-Graduação em Antropologia Social, Universidade Federal do Rio Grande do Sul. 
Neste sentido, o sangue menstrual é pensado como um sangue alheio à mulher que o verte, "de outro tipo", "de outra espécie", em suma, outro sangue. Este não é o mesmo sangue que se distribui por todo o corpo. Expressões de nojo e repulsa são manifestadas pela mulher em relação ao seu próprio sangue menstrual, ao mesmo tempo que o sangue de um ferimento seu nāo provoca nenhuma reação especial. Há um estranhamento em relação ao cheiro e ao estado deste sangue, que é identificado como "forte", "nojento", "grosso", "pastoso".

Ainda que certa ambigüidade esteja presente nesta digressão, poderíamos tomar a não-identificação do sangue menstrual como uma substância própria da mulher (mas como uma espécie de alteridade, um fluido que, se fertilizado, se aloja no útero) como mais um indicador desta lógica que equaciona período fértil com período menstrual. Os termos utilizados para referir-se à menstruação, como "estar de boi" e "receber visita", sugerem também o fluxo menstrual como algo dissociado ao próprio corpo.

As chapueradas que se baseiam nos princípios simpáticos de magia, onde o semelhante age sobre o semelhante, reafirmando o sentido de "tirar" (que é o termo empregado para procedimentos abortivos), estão subordinadas a esta lógica que concebe a menstruação como uma substância fértil por excelência. A elaboração e ingestão das chapueradas revelam pares significativos de oposiçāo e associaçōes como parte desta logica ordenadora de uma visão de mundo e de corpo. $O$ uso destas poções não restringe-se ao uso oral, talvez por isto sejam chamadas de chapueradas e não de chá. Neste caso, de uso não tão difundido, são usadas como ducha ou intravaginalmente, associadas com outros procedimentos abortivos.

As chapueradas, que são uma combinaçāo de diversas ervas, erva-de-passarinho, canela, folha de bergamoteira, ou fervura de vinho, caldo-de-feijāo e cachaça- as receitas e os procedimentos variam em diferentes regiões - têm em comum o fato de que são ministrados quentes (fervendo), associados a alimentos fortes e medicamentos também classificados como fortes, comprados em farmácia. Os medicamentos empregados são aspirinas ou similares, ingeridos em grande quantidade, ou uma cartela inteira de contraceptivos orais, ou ainda, Cytotec (medicação para úlcera de verificada eficácia abortiva) ou outras medicações para o coração. Quanto mais restrita for a venda da medicação, e quanto mais difícil de consegui-la, mais identificado como forte ele será, e isto torna-se também uma medida da eficácia do preparado a ser ingerido.

Alimentos fortes, como a gordura de um determinado animal ou óleos e resinas, fervura de pregos (ferros), são variações incorporadas na chapuerada. As fervuras de ervas, quando associados à cor do vinho e à densidade do caldo-de-feijão ou de substâncias gordurosas, têm um aspecto que mantém uma implícita similitude com o sangue. Fundamentalmente, o líquido ingerido, capaz de desfazer o nódulo da procriação, deve ser forte e quente, como forte e quente é também classificado o sangue menstrual ${ }^{*}$.

Há, em alguns casos, a orientação específica de que a chapuerada deva ser repugnante, isto é, deixar primeiro que a mistura entre em estado de decomposiçăo, sinalizando, pode-se dizer, uma variação do forte, no sentido de ter o poder de causar

Sobre a classificação dos alimentos em fortes, em oposição a fracos, e quentes, em oposiçăo a frios, neste mesmo contexto etnografico, ver Knauth (1991). 
naúseas, fazer vomitar, jogar para fora, expelir. Em outro nível, funciona a simpatia pela similitude entre o nojento da beberagem e o nojento que classifica o fluxo menstrual. As chapueradas devem ser ingeridas pela manhã, quando a paciente está em jejum, e esta deverá permanecer em jejum, em resguardo, coberta e extremamente aquecida (com um tijolo quente ou bolsa de água quente nos pés) até que "a menstruação desça".

Associada à elaboração e à ingestão da chapuerada há sempre algum tipo de procedimento mágico: a reza de uma benzedeira, palavras que devem ser pronunciadas em uma seqüência exata, algum elemento único e de difícil acesso - como a unha de um determinado animal -, e a própria minúcia da receita , que é sempre considerada "especial" e de domínio restrito. A magia não compromete nunca a eficácia do procedimento abortivo, ao contrário, ela o garante: uma overdose hormonal, como é o caso da ingestão de grande quantidade de contraceptivo oral ou medicaçōes que são abortivas como o Cytotec, são apenas um elemento num procedimento de desfazer aquilo que é complexo, e neste sentido, um tanto mágico - a concepção*.

Outros tipos de procedimentos abortivos sobre o qual não nos deteremos aqui como as lavagens, duchas e gotas de aplicação vaginal -, também seguem um mesmo princípio, pois são prescrições que não são imediatamente pensadas como abortivas, mas como interferências "para fazer vir a menstruação."

Tanto as práticas de resguardo quanto as práticas abortivas são geridas por um princípio de que o sangue que está dentro tem que sair, fluir. Isto é parte do equilíbrio das coisas, do pressuposto da necessidade de circulação de fluidos concebido como ordenador do corpo. Dentro desta lógica, o sangue menstrual, quando encontra o esperma, é constituidor da procriação:

"Fecundação não sei bem como funciona, a porra vai lá e faz ofeto."

"O mais arriscado mesmo (para engravidar) é o dia mesmo da menstruação, o sangue sai e o sêmen fica lá dentro. Fora isto, quando os dois gozam ao mesmo tempo."

Os dois depoimentos acima são masculinos, e caracterizam de forma exemplar a associação vigente entre sangue e esperma como substâncias geradoras. Outra informante, mulher com cerca de quarenta anos, diz:

"Tenho uma vida muito corrida, mas quando acordo pela manhã e estou menstruada, lembro que sou mulher, e tenho vontade de transar por causa disto."

Neste caso, o sangue menstrual é percebido como sinal corpóreo de feminilidade e a consciência de ser mulher provoca desejo, disponibilidade para a relação sexual. Depoimentos sobre ter vontade, isto é, desejo sexual, durante o período menstrual, também são recorrentes, ainda que, em certa medida, exista ambigüidade com a noção de ter nojo do sangue menstrual. Em relação a isto, a distinção entre os dias iniciais e finais e os dias fortes do fluxo, ou entre o corpo estar úmido e morno, em oposição a molhado e quente, é

* Sobre procedimentos de cura mágica, ver também Leal (1992). 
importante ser mantida. $O$ início e o final da menstruação é que são indicados como momentos prazerosos. De um modo geral, o fluxo menstrual está vinculado à evitação sexual, "porque é nojento", "é sujo", poluidor ":

"Ter relações durante o periodo, além de nojento, pode ficar grávida."

"É relaxamento ter relações durante a menstruação, mas cada mulher tem um jeito de ficar grávida."

Ou ainda, na fala masculina:

"Mulher menstruada não está limpa, ela está bichada."

"O homem que transa com mulher menstruada pode ficar impotente."

A noção de repulsa, de perigo $c$ de cvitação apresentada sobretudo pelos entrevistados homens não elimina a manifestação de desejo sexual por parte das mulheres que, como foi dito, de um modo geral, evitam ter relações nos dias de fluxo intenso, mas indicam que "quando o corpo está se abrindo e quando está se fechando", isto é, no início e no fim do pcríodo menstrual, este é o momento nāo só mais propício para engravidar (e por isto perigoso), como também o momento $\mathrm{cm}$ que "a mulher tem mais vontade" de manter relações sexuais. Mesmo a idéia masculina de evitação do fluxo por medo de impotência, expressa no depoimento acima, pode ser tomada como um sinal de que ela pressupõe o sangue menstrual como simbolicamente potente, poderoso, forte, fértil.

O sangue menstrual, como foi visto, é sempre indicado como algo sujo, algo a ser eliminado, em alguns momentos como um fluido que opera uma limpeza no corpo, às vezes como um filtro, outras como um resto. Neste sentido, este argumento funciona como mais uma representação de que o corpo imediatamente pós-menstrual é o corpo purificado pela menstruação, como um período recomendável para a fecundação.

No jogo de significações dos humores do corpo que envolvem a menstruaçāo e a concepção, a representação do corpo feminino como algo que se abre e se fecha é determinante sobre todas as outras e é também a chave para comprendermos a lógica da reproduçāo. O corpo é sempre pensado como algo pleno de movimentos internos, uma dinâmica de fluidos determinantes do próprio estado de estar vivo, em oposição ao estar morto, quando a circulação de fluidos inexistiria. O corpo da mulher é portador de uma cavidade oca - o útero -, espaço onde se desenvolverá o feto. O sangue menstrual é específico e indicador da condição de fertilidade feminina. A mulher passa a produzi-lo ciclicamente quando se torna mulher, quando está apta à reproduçāo (menarca) e deixa de produzi-lo (menopausa), esgotando a sua fertilidade. Este fluxo sangüíneo é limpo enquanto construtor de vida, é sujo quando resto de tudo que não presta mais no corpo, enquanto um filtro, e neste caso deve ser evacuado, daí as práticas de resguardo: como cle

* A literatura antropólogica apresenta extensivo material a respeito de diferentes culturas onde o sangue menstrual é percebido como impuro, poluído e poluidor. Neste sentido, ver por exemplo, Douglas (1976) e Helman (1984). Para o sangue menstrual como poluidor, mas funcionando como um filtro que limpa o corpo, no mesino sentido de nossos dados, ver Brandes (1980). 
é sujo e deve sair, nada deve interferir em seu curso. A gravidez não desejada passa a ser pensada como um resto, um sangue que deve ser eliminado.

A noção do corpo que se abre e fecha é marcante tanto nas falas masculinas quanto femininas. O sangue menstrual é matéria fértil, mas como os órgãos estão expostos deve ser evitado o contato vaginal nos dias intensos do fluxo, permanecendo os períodos imediatamente anteriores e sobretudo os imediatamente posteriores como ideais para a fecundação. A noção de fecundaçāo ocorrendo em contigüidade com a menstruação é fundamental. A abertura, o calor e umidade do corpo, e a necessidade da presença de um fluido condutor dão coerência ao processo reprodutivo nesta representação. Estas representações nos indicam um modelo cultural de corpo que inclui noções de uma dinâmica de abertura e fechamento do corpo, circulação de substâncias condutoras, estados de umidade e calor, implicando na percepção de limites (ou a ausência deles) em relação ao corpo feminino:

\section{"Não se deve ter relaçōes durante a menstruação porque o corpo está todo aberto, saindo aquela sangueira toda." \\ "Três dias antes de ficar menstruada o útero fica aberto e daí qualquer coisinha fica grávida e depois da menstruação, quando o utero ainda näo fechou."}

"Logo depois da menstruação a mulher pode engravidar, porque ela está limpa."

Observe-se que, do ponto de vista feminino, há um procedimento de evitação de relações sexuais nos dias fortes do ciclo menstrual, ou porque "dá em filho" ou porque é inconfortável, "muita sujeira", "nojento". Em relação ao homem, é indicado não uma abstenção da relação sexual, mas uma evitaçâo do contato com o sangue menstrual:

"Quando a mulher está grávida ou menstruada deve-se fazer o sexo anal para não marcar o nenê."

Este depoimento masculino apresenta também uma equivalência lógica entre mens-truação e gravidez.

Em primeiro lugar, a fecundaçāo é percebida como um evento fisicamente íntimo de consubstanciaçāo de sangue e esperma. Segundo, os estados do corpo, tais como temperatura e umidade, são condições de fecundação neste modelo. Terceiro, a necessária circulação de humores corporais é regida pela lógica de um corpo que funciona com um operador binário, que se abre e se fecha. A dinâmica dos fluidos masculinos e femininos é a forma do mundo íntimo e interior, fisiológico, estabelecer relaçōes com o mundo de fora, o mundo social. Além disto, a partir de nossos dados, podemos incluir uma quarta dimensão neste modelo a uma lógica situacional que ć da ordem da aleatoriedade dos fatos. Neste sentido, a relação sexual para ser fecunda podc estar condicionada também a circunstâncias como a intensidade do ato, a qualidade da relaçāo. as condições temporais, espaciais e sociais, tais como: 


\section{"Quando se goza junto pega filho."}

\section{"Quando chove, quando está tudo úmido, eu aprendi isto no curso no hospital."}

\section{"Acho que em maio, que é mês das mães e mês das noivas."}

O número de relatos de pessoas que indicam que durante a menstruação engravidaram ("eu engravidei no intervalo dos comprimidos") ou estando usando D.I.U. é massivo. Estes dados só podem ser entendidos a partir deste referencial, onde carece de significado a administração de contraceptivos orais, entre outra coisas, se é necessário deixar de tomá-los "exatamente" durante o período menstrual. O fato de que a administração de hormônios diminui o fluxo menstrual é também identificado como problemático, porque "retém um sangue que deveria sair", obstrui a circulaçāo dos fluidos. Como não faz muito sentido também a indicação da regularidade de sua administracão, sua má-administração pode ser considerada um fato, o que por sua vez compromete a crença na sua eficácia. $O$ Dispositivo Intra-Uterino (D.I.U.), por causar períodos menstruais longos e sangramentos fora do período, também é visto com desconfiança: como pode evitar gravidez se, de fato, produz mais fluxo. Além de - $\mathrm{e}$ isto é fundamental entender - o fluxo sangüíneo contar com uma evitação masculina, no que se refere a relações vaginais (e neste caso, na insistência em relaçōes não-vaginais, é possível que violência sexual se faça presente), este dado não deve ser subestimado na avaliação das restrições que as mulheres fazem ao uso do D.I.U.

Isto explica, pelo menos em parte, o perfil contraceptivo desta população específica. Os dados referem-se à população feminina em período reprodutivo (quinze a quarenta $\mathrm{e}$ nove anos). Dizem respeito a dois estudos epidemiológicos com seis anos de intervalo, referem-se a 1986, início da implantação do posto de saúde naquela área, e a 1992, estudo epidemiológico de Takeda (1993). Ver tabela na página vinte e três ${ }^{*}$.

A partir dos dados etnográficos, nossa avaliação é de que, apesar dos dados quantitativos indicarem o uso significativo da pílula (39\%), o aborto permanece sendo um grave problema de saúde, dada a sua ilegalidade, de dimensões imensuráveis ${ }^{* *}$. 0 uso de D.I.U. é uma alternativa para apènas $2,9 \%$ das mulheres na vila, e não houve modificação nesta taxa depois de seis anos de presença do posto de saúde. Ambas alternativas - o baixo índice do uso do D.I.U. e a irregularidade do uso da pílula, com sua conseqüente ineficácia - contribuem para uma crescente demanda feminina por esterilização cirúrgica.

* Os dados estatísticos de 1986 são do Diagnóstico de Saúde da População da Área de Abrangência do Posto do Valão, Serviços de Saúde Comunitária, Hospital Conceição, Porto Alegre, 1986. Pesquisa feita pela equipe de epidemiologia, coordenada por César Victora e Fernando Barros. Os dados mais recentes referem-se ao segundo diagnóstico de saúde comunitária. A pesquisa foi coordenada por Silvia Takeda. A reorganização dos dados na forma aqui apresentada são também de Takeda (1993).

** Dados quantitativos sobre aborto não são disponíveis, em nossa própria pesquisa. Dados preliminares indicam a enorme difusão de práticas abortivas. Seguindo a discussão apresentada no $44^{\circ}$ Congresso Brasileiro de Ginecologia e Obstetrícia, Brasilia, novembro de 1991, há uma estimativa de 5 milhỏes de abortos, em contraste com 3,5 milhões de nascimentos no Brasil, para o ano de 1991. Para o mesmo ano, 275 mil mulheres foram hospitalizadas (apenas em hospitais servidos pelo INSS) com complicaçōes pós-abortivas, dados da OMS. Porto Alegre, Correio de Povo, 01.11.92. 
Há um número relativamente alto de ligadura tubária (7\%), sendo o segundo método contraceptivo mais usado ${ }^{*}$. A presença do posto, que tem uma política contrária à ligadura, e que não oferece a esterilização como alternativa contraceptiva, incentivando outros métodos, não foi suficiente para indicar uma diminuição significativa na busca da ligadura tubária, pois o número manteve-se praticamente constante. Os dados etnográficos põem em evidência uma forte demanda (feminina - os homens se manifestam contrários) por esterilização feminina e uma queixa pela impossibilidade ou a grande dificuldade de ter acesso a isto. A ligadura é identificada como o método contraceptivo por excelência, em detrimento de outras alternativas, acionando problemáticas correlatas de aumento de número de partos por cesariana e irreversibilidade do processo ${ }^{* *}$.

A análise antropológica abordando a cstrutura das representações sociais a respeito do corpo e da reprodução, peculiar a este grupo, nos leva a entender melhor os dados estatísticos, que nos indicam também que $29 \%$ das mulheres, embora manifestamente não querendo engravidar, não fazem nenhuma contracepçāo. Este número aparentemente apresentou uma melhora significativa em relaçāo aos dados de 1986 (quase dez pontos percentuais). Considerando que com as aproximações necessárias nos dados de 1986 (para ser possível a comparacão entre as duas tabelas), sejam procedentes, o que nós temos é que houve um aumento de uso de contraceptivo oral. Além disto, de fato, a presença do posto de saúde funcionou, em parte, como um incentivo à reprodução, uma vez que serviços médicos, sobretudo assistência pré-natal $\mathrm{e}$ infanto-materna são eficazmente oferecidos. A taxa de mulheres grávidas e querendo engravidar dobrou (de $3.3 \% \mathrm{~cm} 1986$, para $6,7 \%$ em 1992). Mas como a população total da área diminuiu, de $7.650 \mathrm{em} 1986$, para 6.565 habitantes em 1991, é possível inferir que outras práticas contraceptivas, além das indicadas, tais como o aborto, tenham sido intensificadas.

Indicando certa ambigüidade neste processo, ao mesmo tempo que há a presença dos serviços de saúde, o número de usos de métodos tradicionais tais como chás, chapueradas, gotas, aumentou em dois pontos percentuais. De outro lado, condom passa também a apresentar $2 \%$ de uso manifesto (elnograficamente não encontramos esta indicação do uso do condom como método contraceptivo). Os números relativos a métodos também tradicionais, como abstenção sexual temporária e coito interrompido, também se mantiveram mais ou menos constantes. $O$ dado novo foi detectar um número relativamente alto de mulheres estéreis (ou homens), discriminado da esterilização cirúrgica, mulheres $\mathrm{cm}$ menopausa (antes dos quarenta c nove anos) e mulheres com histerectomia. A questão que permanece é se estes números não espelham também um aumento no número de abortos. auto-infligido ou feito pelas parteiras, distante de condições médicas. Nāo pode

* De outro lado, o número de esterilização feminina é relativamente baixo se comparado com a taxa de $27 \%$ de esterilizaçāo feminina de mulheres entre 15 a 54 anos. média para o Brasil, dados de 1987. PNAD-IBGE. (Dados apresentados no Relatório da Comissão Parlamentar de Inquérito sobre Esterilização Feminina. Porto Alegrc. Jornal Zero Hora. 15.12.92). Conforme PNAD, a taxa de csterilização feminina para o Estado do Río Grande do Sul é de $8 \%$, a menor em relação a outros Estados do Brasil. Neste sentido, a taxa de $7 \%$ para esta população específica, que é de situação econômica bastante precária, favelada, pode ser considerada não tão drástica.

** No Brasil. a esterilização cirúrgica é restrita por lei. devendo haver indicações clínicas específicas. O parto por cesariana tende a acompanhar a esterilizaçāo por motivos práticos e como uma forma de melhor justificar a ligadura. Neste sentido, ver Barros (1991), Osis (1990) e Rios-Neto (1991), entre outros. 
ser esquecido que estes seis últimos anos coincidiram com uma difusão massiva do Cytotec. Neste caso, outras questões a respeito de saúde reprodutiva devem ser abordadas ${ }^{*}$.

Neste trabalho, busquei indicar de que forma se estrutura a coerência da lógica da reproduçāo em uma vila de classes populares no Sul do Brasil. Este repertório cultural específico nos conduz a um melhor entendimento, por um lado, da eficácia limitada do uso de alguns métodos contraceptivos e, por outro, explica, pelo menos em parte, uma demanda feminina por esterilização cirúrgica, não necessariamente atendida. Isto também nos conduz a duas outras sérias questões relacionadas com saúde reprodutiva: o aborto amplamente difundido e praticado em condiçōes extremamente precárias, e a demanda por cesariana, que acompanha a demanda por esterilização cirúrgica. Os dados revelam também uma realidade de práticas e procedimentos contraceptivos tradicionais inseridos e encompassados com um sistema médico moderno em uma sociedade urbana.

\begin{tabular}{lcc}
\hline MULHERES DE 15 A 49 ANOS, VALÃO, P. ALEGRE & 1986 & 1992 \\
\hline Contraceptivo oral & 32,7 & 38,7 \\
Ligadura tubária & 7,8 & 7,1 \\
D.I.U. & 2,9 & 2,9 \\
Coito interrompido & 1,6 & 1,4 \\
Tabela & 2,3 & 1,6 \\
Vasectomia & - & 0,2 \\
Condom & - & 2,5 \\
Outro método/ métodos tradicionais & 1,3 & 3,2 \\
Nenhum método & 48,0 & 29,4 \\
Nenhum método. quer engravidar & 0,7 & 2,6 \\
Nenhum método, grávida & 2,6 & 4,1 \\
Não-classificados (menopausa, esterilidade fem. & & \\
ou masc. e histerectomia) & - & 6,2 \\
\hline
\end{tabular}

* Dado o que indicamos como extremamente disseminado - as práticas abortivas nesta população hipoteticamente deve ser investigada a possibilidade de estas práticas, realizadas em condiçōes de higiene extremamente precárias, não serem também um foco possível de transmissão de doenças sexualmente transmissíveis, sobretudo a AIDS em mulheres. Se năo pelo procedimento abortivo em si, pelo número de lesōes vaginais e uterinas associadas a relaçōes com parceiros de risco. Os dados de AIDS no Rio Grande do Sul indicam um crescimento significativo de casos em mulheres. 



\title{
"MULIER, MULER: SAÚDE, TRABALIIO, COTIDIANO"
}

\author{
Castro, A. L. \\ FARIA, M. M. \\ ADORNO, R.C.F. \\ ZIONI, F.
}

\section{INTRODUCÃO}

Este trabalho busca abordar um problema das sociedades industriais complexas que vem sendo delimitado como uma questão de Saúde Pública e que tem sua origem na forma de organização do trabalho - a lesão por esforço repetitivo - procurando lançar o olhar sobre as particularidades do cotidiano de mulheres lesadas.

Abordando a maneira como a doença interfere no "modo de vida" de mulheres por ela acometidas. alterando a subjetividade, a rede de sociabilidade e a autonomia - capacidade de açăo - dessas mulheres, este trabalho ganha traços de uma abordagcm que se aproxima do escopo da antropologia.

Lesð̃es por esforços repetitivos (L.E.R.) é o termo utilizado hoje no Brasil para definir uma sindrome caracterizada pelo desconforto, incapacidade ou dor persistente em articulaçðes, músculos, tendőes e outros tecidos moles, com ou sem manifestações físicas ou clínicas.

Ao contrário do que esta definição à primeira vista possa sugerir, os fatores envolvidos no desenvolvimento desta síndrome são inúmeros e a repetitividade de movimentos é um deles, identificado nas atividades laborais da maioria da população acometida por esta afecção (Cristensen, 1986; Ohara, 1976; Onishi, 1976). Alguns dos outros fatores concorrentes são a rapidez de movimentos, a carga estática sobre os músculos posturais do pescoço e ombros, sobrecarga de determinados grupos musculares, uso de instrumentos inadequados e muitos outros relacionados com a organização do trabalho, como tarefas empobrecidas e fragmentadas, exigência implitica ou cxplícita de produtividade, duração de jornada prolongada. dificuldade de interrupção do trabalho para necessidades fisiológicas. 
Em 1960, o OIT (Organização Interamericana do Trabalho) reconhoceu esta síndrome como doença ocupacional. A legislação brasileira que a reconhece como do trabalho refere-se à Tenossinovite do Digitador (Portaria MPAS/GM n 4062).

Os sintomas de dor, formigamento e falta de força, em geral, são de aparecimento insidioso. Pouco a pouco passam a fazer parte da vida do trabalhador de forma despercebida pelo mesmo. Após algum tempo, esses sintomas tornam-se mais intensos e passam a incomodá-lo durante o sono, impondo-lhe limitaçes em suas atividades cotidianas. No Brasil, não há uma política institucional que vise à prevenção e o diagnóstico precoce dessas doenças.

Assim sendo, a ñ̃o ser em caso de pessoas alertadas por campanhas, principalmente de sindicatos, somente após uma clara e contínua interferência da afecçăo sobre suas vidas os trabalhadores procuram auxilio médico em serviços conveniados com empresas ligadas à medicina de grupo ou públicos.

Encontram estruturas despreparadas e pouco sensiveis aos sintomas referidos por eles, que por apresentarem ao exame fisico pouco ou nenhum sinal indicativo de alteração e sendo os exames complementares de pouca ajuda, a não ser em casos específicos, enfrentam o descrédito dos médicos. Recebem tratamento fisioterápico e medicamentoso e mantêm suas atividades de trabalho, o que agrava a afecção, trazendo-lhe incapacidade não só para movimentos no trabalho como em casa. Assim, além de năo conseguirem mais trabalhar, passam a depender de terceiros até para algumas atividades de higiene pessoal e, scm dúvida. para as domésticas, como lavar e passar roupa, cuidar dos filthos, lavar louças e outros afazeres desenvolvidos principalmente pelas mulheres.

A simples observação das tarefas delegadas às mulheres em nossa sociedade revela que, dentro da divisåo sexual do trabalho existente, o trabalho feminino é sempre associado a funçð̄es de assistência e cuidados, bem como a tarefas que exigem habilidades manuais e coordenaçăo motora fina. Contrariamente, ao homem são delegadas atividades que exigem maior esforço fisico: nas linhas de montagem das indústrias compete ao homem o exercício de atividades ligadas a máquinas mais pesadas.

Esta condição parece ser comprovada através da análise da demanda de dois Programas de Saúde do Trabalhador (PST), a partir de dados constantes das Comunicaços de Acidentes de Trabalho (CAT). Esta análise revelou que os homens estäo mais expostos a eventos "agudos" ou a acidentes de trabalho propriamente ditos, uma vez que $78,37 \%$ desses episódios ocorrem com o sexo masculino.

Por outro lado, dos 632 casos de L.E.R. apresentados, no período de 1987 a 1991, ao Programa de Saúde do Trabalhador do Mandaqui, a grande maioria (84\%) é do sexo feminino. Deste, $46 \%$ constituem-se de mulheres inseridas em atividades do setor industrial e $27 \%$ săo trabalhadoras do setor financeiro (bancos, financiadoras, administradoras de cartăo de crédito).

Ao desmembrarmos esse período, observamos que nos anos de 1990 e 1991, dos 376 pacientes avaliados com diagnóstico de L.E.R., 74,5\% tinham até 35 anos de idade, $85,9 \%$ eram mulheres, e havia diversidade entre os ramos de atividades, com predominância do metalúrgico $(38,3 \%)$ e financeiro $(31,1 \%)$.

Também, nas estatisticas do Núcleo de Saúde dos Trabalhadores (NUSAT) de Bclo Horizonte, em publicaçăo de Normas Técnicas para Avaliaçăo da Incapacidade do Minis- 
tério do Trabalho e Previdência Social (MTPS, 1986), observamos que, tanto em 1987 como em 1989, a população diagnosticada com L.E.R. foi predominantemente feminina (71\% e 76\%, respectivamente). Quanto aos ramos de atividades, embora em 1990 fosse identificado um crescimento de demanda de trabalhadores de linhas de montagem, a predominância foi de digitadores.

A literatura, no entanto, indica que a L.E.R. é uma síndrome que atinge as mais diversas categorias profissionais, as quais apresentam fatores propícios já citados anteriormente para a sua manifestação (Cristensen, 1986; Linton, 1989; Maeda, 1975-1977; Ohara, 1976; Onishi, 1976).

A experiência realizada pelo Programa de Saúde do Trabalhador (PST-ZN) - de acompanhamento de pacientes com L.E.R. desde 1987 - aponta para a percepção da dimensão social do problema pois trata-se de uma doença crônica. dolorosa incapacitante, de regressão lenta. mesmo após meses e anos do afastamento dos pacientes dos estímulos, - que traz em si uma grande sensação de angústia, tanto aos acometidos como aos profissionais de saúde que os acompanham.

Quanto ao sexo, a L.E.R.. assim como as doenças músculo-esqueléticas em geral, parece, segundo a hipótese de alguns pesquisadores, atingir mais frequientemente as mulheres. Segundo Barnard (1982) "os músculos das mulheres não possuem o mesmo potencial de desenvolvimento que o músculo dos homens. Ela possui menor número de fibras musculares e menor capacidade de armazenar e converter o glicogênio em energia útil. Seus ossos também tendem a ser mais leves e mais curtos, com áreas de junção mais reduzidas" (Barnard, 1982).

Ainda segundo o autor, outros fatores parecem influenciar essa predominância entre as mulheres, como: uso de anticoncepcionais: trabalhos domésticos após a jornada profissional; realização de inúmeras funçðes industriais repetitivas devido à sua habilidade.

Buscaremos aprecnder, neste trabalho, como a L.E.R. interfere no espaço social feminino, uma vez que a construção da identidade feminina na nossa sociedade, ainda hegemônica, passa pela responsabilidade de garantir a organização do lar, através da administração e cxecução do trabalho doméstico e cuidado dos filhos, atividades estas que requerem. em sua majoria, o trabalho manual. Convém ressaltar que optamos por trabalhar com pacientes do sexo feminino devido à sua predominância nas CATS dos dois programas referidos, não pretendendo com esse corte desprezar o trabalho masculino no lar - que também exige habilidades manuais, como pequenos consertos, por exemplo - nem tampouco minimizar as possíveis angústias geradas pelo impedimento de continuar sendo ele o provedor da familia.

Encontrar-se em uma situação de "imobilidade física" - tal como a que provoca a doença - pode estar associado, ainda, à desestabilização de sua relação afetiva com seu parceiro, scja cle namorado, marido ou companheiro.

Estar impossibilitada total ou parcialmente de exccutar essas atividades - o que significa não estar correspondendo a uma expectativa sua e de seus familiares, quanto ao que é ser mulher - estaria concorrendo para a vivência de sofrimento e, mais, para a necessidade de lidar com a internupção, ainda que não definitiva de um projeto de vida pessoal, familiar, afetivo e profissional, cujos padrões têm sustentação social. 
Diante da situagato exposta acima, optamos por tentar identificar, a partir da visăo das mulheres portadoras de L.E.R., a interferéncia dessa lesão no seu cotidiano, nos âmbitos da vida doméstica, afetiva e profissional.

\section{METODOLOGIA}

Foram realizados cinco entrevistas grupais, não diretivas, com usuárias do Programa de Saúde do Trabalhador (PST/ZN), em sessöes sistemáticas que exploraram o cotidiano dessas mulheres com relação à doença. Estas foram gravadas, transcritas e codificadas de acordo com temas levantados após a escuta das mesmas, conduzindo para uma análise temática.

O grupo era composto por mulheres lesionadas, com uma média entre 30 e 40 anos, profissionais da linha de produção. secretárias, costureiras industriais, digitadoras, laboratoristas e empacotadoras industriais. O número de participantes foi de 12 a 15 por reunião.

Optamos por trabalhar com dinâmica de grupo como fonte de dados, pois esta, além de fornecer elementos para análise das relaçð̃es familiares, dos processos de mudança e redefiniçăo de identidades, e das resistências que vêm da existência de leis sociais e culturais, contribui simultaneamente para o alivio das preocupaçes de ordem prática das pessoas que estão em situaçào problemática.

Autores como Kurt Lewin e Barbier (1985) desenvolveram urna discussão metodológica a partir de experiências de pesquisas com grupos.

Avançando no sentido da vinculação entre teoria e empiria, Barbier (1985) propðe a utilização da noção de "clínica" em ciências humanas, definindo o método clínico. Este serve-se da abordagem qualitativa monográfica e é aplicado de preferência no preparo do terreno da investigação. A intenção é explorar o comportamento e as representą̧ð̃es de um sujeito ou de um grupo de sujeitos diante de uma situação concreta para compreender-lhe 0 sentido.

Bachelard, citado por Barbier, refere que "as regiōes parceladas do saber se ressecam como palha de sol: o homem voltando a ser natural compreende que a natureza é cultural e que a cultura não pode ser separada da natureza". Diz ainda: "é preciso que haja homens conectores que possam representar a totalidade representada pelo real e pelas diferentes regioes do saber, como entre o pensamento e o real, cujo único denominador comum é a práxis social e histórica. Fora a práxis, não há conhecimento possivel" (Barbier, 1985:167).

Assim, o pesquisador clínico refere-se geralmente a abordagens qualitativas, registrando as particularidades individuais. Limita-se a uma ética do conhecimento, escrevendo sobre uma determinada vivência.

A experiência por nós desenvolvida neste trabalho, de avaliação do conteúdo da dinâmica de grupo de aconselhamento para mulheres portadoras de L.E.R., foi muito oportuna, uma vez que estas se identificam com as outras integrantes, reforçando o sentimento de pertencimento a um grupo. Também foi interessante no sentido de que as mulheres portadoras de L.E.R., com sua auto-estima prejudicada, tiveram a oportunidade 
de perceber que os problemas por elas vivenciados não sł̆o só seus, compartilhando vivências, experiências e até saidas alternativas para situą̧̋es concretas colocadas no cotidiano. Neste sentido, o grupo, além de ser objeto deste estudo, fornecendo dados que permitem conhecer um pouco da realidade destas pacientes, também possibilitou às participantes um olhar diferenciado sobre a situação, levando à redefinição do problema, de suas identidades, e à busca de alternativas de mobilização politica para a mudança de suas condiçðes.

\section{RESULTADOS}

A análise do matcrial de entrevista permitiu-nos a identificação de três eixos temáticos: a questão profíssional, rclaçð̃es sociais/afetivas e atividades da vida diária.

\section{Vida Profissional}

Dentro da questão profissional. foi possivel percebermos duas situaçőes distintas: a de demitidas e a de afastadas.

No primeiro grupo, a grande problemática apontada foi a dificuldade de reinserção no mercado de trabalho, pois essas trabalhadoras necessitam ser readaptadas cm funçăo diferente da que exerciam c na qual, geralmente, năo têm nenhuma cxperiência c necessitam recomeçar da "estaca zero".

"... eu trabalho desde os 17 anos, estou com 37 e estou há dois anos vivendo esse pesadelo, são os piores de minha vida... me sinto muito mal porque ndo sei o que vai ser. Acordo e ndo tenho o que fazer, é muito duro ficar à toa".

É importante frisarmos que a doença aparece na metade da vida útil. quando o recomeço é mais difícil, pois o peso do processo de envelhecimento começa a ser percebido.

A sensaçào de perda também foi muito referida durante as entrevistas, sensação essa que contribui para a depreciação da auto-estima, aguçando os conflitos, tanto no âmbito profissional como no familiar e doméstico.

"... O médico disse: você não pode mais fazè o mesmo sen'iço. Eu fiquei desesperada, estava aleijada, sei lá... eu me descabelei, fiquei doente da mđo e da cabeça. Eu alhava prá pessoas e chorava... depois a gente vai se apercebendo da doença, vai entendendo, conhecendo melhor os limites..."

Dificuldades geradas pela "canteira suja" também foram apontadas, pois consta demissão, e são constantemente intcrrogadas sobre o motivo. Foram relatados casos em que providenciou-se nova carteira, mas apareceram dificuldades $\mathrm{cm}$ se passar nos testes, uma vez que os empregadones exigem que se faça movimentos com as mãos, já suspeitando do fato de a candidata à vaga ser lesionada. 
Percebemos ainda, neste gnupo de demitidas, um sentimento de revolta com relação à empresa, devido à "ingratidão" após tantos anos de dedicação.

"... na empresa eles estao preocupados com a produçđo, näo com a gente. Quem nao produz mais vai embora..."

Convém lembrar que, segundo a legislacão, nenhuma dessas mulheres poderia ser demitida, porém, ao freqüentarem os médicos - tanto da empresa em que trabalhavam, quanto da rede pública - elas não obtiveram o diagnóstico médico de doença ocupacional, e com a produção cada vez mais baixa tiveram como destino a demissão. Algumas estão recorrendo à Justiça para serem indenizadas pela empresa responsável por suas lesőes irreparáveis, mas é sabido que o processo é moroso, levando no mínimo cinco anos, o que ñ̃o resolve scus problemas imediatos.

Quanto ao grupo das mulhercs que se encontram em situação de afastamento, a principal dificuldade apontada diz respeito, como no grupo de demitidas, ao recomeço em novas tarefas, para os casos que se encontram em realocaç̃o.

Næo obstante. também experimentam discriminaçð̌s no ambiente de trabalho, tanto de colegas como da chefia, que passam a vê-las como funcionárias acostumadas a "encostar", face às constantes consultas médicas e retomos freqüentes, necessários até o diagnóstico defínitivo da doença.

A freqüência das consultas médicas também acaba por constituir-se em um problema, pelo fato de fazer emergir conflitos entre a empresa contratante, os convênios existentes e a instituição especializada em diagnóstico de doença ocupacional, que muitas vezes se recusa a entender o problema como de doença do trabalho, gerando desgastes entre a paciente e a cmpresa, fazendo-a retornar inúmcras vezes, insinuando que o problema năo foi adquirido no ambiente de trabalho, interrogando sobre outras atividades corriqueiras, etc.

"... eu tinha muita dor, eu tinha dormência há uns três anos, muita dor na coluna cervical, o médico de lá falava que era problema de postura, de colchäo... um belo dia eu disse: tenho que tomar uma decisão, inclusive porque estava afetando minha produção. Al eu fui procurar o médico da empresa, que me mandou para o convêncio, então eu recebi o diagnóstico de sindrome... fiquei imobilizada uma semana com Voltaren, ai ele disse para voltar a trabalhar novamente."

"... Até a gente passar pelo perito do INPS... primeiro a gente passa pelo convênio, depois marca consulta na pericia - eu nunca vi, passa prá lá, passa prá cá, passa pela assistente social, passa no médico... entzo é preferivel segurar esse negócio na companhia do que levar pro INPS, porque quando chega lá eles näo quer acreditar na gente, acha que a gente tó inventando a doença."

"... a gente passa por tanto médico, é o ortopedista, é o reumatologista..." 
Esse conflito é gerado pela dificuldade de precisão no diagnóstico - devido, em boa parte, à "invisibilidade" da doença; além disso, existc uma divergência entre a classe médica com relação ao problema - que ć novo - e um despreparo destes profissionais para diagnosticar doenças ocupacionais. Atestou-sc divergência entre os profissionais médicos também em relação à condula para o tratamento.

"... passei dois a três meses com o braço enfaixado, porque eu tinha muita dor, então eu ia até a enfermaria e eles passavam uma pomada, enfaixavam e mandavam de volta para o tratamento.

"... Passei no clinico geral, ele me enfaixou o pulso, disse que era tendinite e me mandou de volta para o trabalho, depois continuou a dor e eu fui para o ortopedista, que mandou me engessar. Depois tirei o gesso e fui trabalhando até nõo poder mais, continuei de médico em médico, até achar um que sabia o que estava fazendo..."

O médico referido no relato acina. além de diagnosticar tendinite. recomenda a volta ao trabalho. Vale frisar que a entrevistada trabalha como laboratorista. isto ć. com o manuscio de pequenos tubos e conta-gotas, atividade que requer o esforço continuo e repetitivo das mãos.

\section{Relaçðes sociais / afetivas}

A demora do diagnóstico acima referido é aliada à dificuldade da paciente em perceber o processo do adoecer. retardando o início do tratamento e das medidas nccessárias para amenização do problema; essa dificuldade emergiu na fala de todas as integrantes do grupo, como na que segue:

"... eu não conseguia segurar um copinho de papel, digitar nem se fale, e era obrigada a trabalhar porque não tinha ringuém para pôr no meu lugar, mas a gente nessa fase ainda noo acordou e nem passa pela mente o que está acontecendo e as consequèncias. A gente está sentindo mas não está a par da gravidade daquilo, quando alguém vem e fala, parece que desaba aquilo na sua cabeça pra você acordar..."

Esse processo de aceitaçào da doença e da dor mostra-se longo $c$ angustiante. Uma vez aceita a doença, as mulheres vêcm-se diante da impossibilidade de cumprir scu papel de mulher, esposa e måe, devido às limitaçőes que a doença gera, implicando, mais uma vez, depreciação da auto-estima:

"... Até a gente sabè o que tem, já sofreu muita humilhação e muita d6."

Durante as sessões de entrevista, foram muito freqücntes as queixas relativas à incompreensão do marido/companheiro. Mais uma vez, o fato de a doença năo apresentar 
nenhum sintoma aparente contribui para a emergência de conflitos, desta vez, na esfera doméstica.

"... Meu marido ds vezes reclama de ter que me ajudar, acho que ele pensa que estou preguicosa, indolente. Castuma dizer que a gente do norte ndo gosta do batente. Acho que se a coisa piora, ele acaba me largando..."

Os conflitos relativos à divisłà do trabalho doméstico são extrapolados para a esfera da sexualidade e do desejo, que passa a ficar comprometida. De um lado, um marido cansado e sobrecarregado, $\mathrm{e}$ de outro uma mulher magoada com o parceiro e com sua auto-estima ferida.

A relaçăo com os filhos também é sensivelmente alterada. Com a mãe lesionada, passam a ter que colaborar nas tarefas domésticas $\mathrm{c}$ a estarem mais presentes nos afazeres cotidianos.

"... na minha casa é uma luta, eu tenho dois filhos que me ajuda um pouco, eu näo lavo, ndo passo. O dia que eu preciso e nđo tem jeito eu faço, mas a dor é insuportóvel."

É interessantc percebermos. através dos relatos, que para as crianças essa condiçăo não vem constituir-sc num problema, pois atć gostam, sentem-se importantes e participativos.

"Meu filho gosta de me ajudar. Quando eu desço do ônibus ele já vem correndo pró me ajudar a carregar a bolsa."

Contudo, para a mãe a situação é muito desconfortável. Em geral sente-se mal, exploradora, acreditando estar sacrificando a infância do filho ou "falhando" como mäe.

"Como dar colo? Mas sem dar colo eu ndo estaria falhando como mde?"

As discussōes do grupo com relaçăo a essa questão foram muito dificeis e conduziram para alguns pontos que podem aclarar a problemática, na medida em que apontaram para a grande cobrança que as próprias mulheres se impðem no seu papel de mäe, que implica onipotência e oniprescnça.

"... A gente tem uma tendencia a abarcar o mundo com as mãos. Porque a màe tem que estar sempre pronta, d disposiçdo?"

Ser mä̌e é ser "supermake", estar presente e disponivel em todos os momentos, e o não cumprimento desse papel - o caso de quase todas, pois trabalhavam - gera sentimentos de muita culpa, que se agravam ainda mais ao deixarem as atividades profissionais e "sacrificar" o filho. Portanto, a impossibilidade de cumprir este papel contribui também para a alteracto da auto-estima. 


\section{Atividades da vida diária}

Atividades exercidas independentemente da familia e do trabalho, como fazer compras. higiene pessoal, dirigir, atividades domésticas, são aqui entendidas como "atividades de vida diária."

Estas atividades também sấo comprometidas pela dor e pela perda de movimento e do tato.

"... eu estava comentando outro dia que levei horas para escolher feijoo, quando acabei minha mäo formigava demais. Tomo Voltaren e anestésico todo dia. Tenho uma pessoa que me ajuda de 15 em 15 dias, mas as coisas são banais demais e eu nao consigo mas fazé.

Pequenas coisas do dia-a-dia. realizadas quase que automaticamente, como se fossem increntes à natureza humana. e não processos aprendidos e construidos, são impossiveis de serem exccutadas, como, por exemplo, locomover-se.

"... Teln umas fases que ndo dá para guiar. Quando é uma reta é mais tranquilo, mas é dificil segurar nas cunvas, e para estacionar entżo é um transtorno..."

"... Eu ndo consigo segurar no banco do ônibus e do metrô, dói muito, a gente tem que escolher entre cair ou sentir dor..."

Tanto pegar ônibus quanto dirigir são atividades muito dificcis para o lesionado.

Há ainda o caso das mulheres de classe média, também acomctidas pela L.E.R., onde os projetos de vida. significado do trabalho $\mathrm{c}$ formas de relacionamento familiar $\mathrm{e}$ afetivo sð̃o distintos da mulher opcrária. porém para essas mulheres verificou-se que a lesão significa a perda de uma possivel autonomia financcira e do engajamento no mercado de trabalho, o que lhes impossibilita o acesso a um circulo social cxtrafamiliar, à informação, ao consumo, dentre outras coisas.

Em suma, estar lesionada significa sof rer perdas fisicas, sociais, afelivas, familiares, onde os projetos de vida sāo interrompidos. Significa ainda a perda de uma autonomia conquistada através de sua inserção no mercado de trabalho formal.

Como último aspecto identificamos, nas mulheres portadoras de L.E.R. atendidas no PST-ZN, uma indefinição com relação ao futuro próximo, gerando angústia e sofrimento psiquico.

"... Qual a soluçao para esse problema? Até agora ninguém falow nada, parece que ndo há perspectiva do futuro. Os médicas dizem que vocé tem que aprender a conviver con isso, mas a gente ndo sabe o que vem por at..." 


\section{CONCLUSÕES}

O discurso das mulheres revelou, conforme já descrito na literatura mencionada, que os sintomas aparecem de forma gradativa, se inıcgrando no seu cotidiano, que só se apercebem da gravidade quando a doença se instalou de forma crônica, muitas vezes irreversivel. A dificuldade de diagnóstico, associada ao despreparo dos profissionais para estabelecer o nexo de causalidade entre os sintomas e a atividade profissional do paciente, leva a um percurso longo e doloroso pelos ambulatórios médicos, acompanhados de sentimentos de impotência, desordens mentais e insônias, até o conhecimento da doença.

A falta de informação dos trabalhadores sobre os riscos advindos da execução de tarcfas repetítivas diárias, năo acompanhadas do devido descanso, bem como a falta de informação das chefias sobre os limites do trabalho e sobre a importância do descanso $\mathrm{e}$ da realocação para outra atividade quando do aparecimento de sinais de fadiga muscular vem gerando uma tendência de crescimento progressivo da doença ocupacional tratada neste estudo.

Observa-se a necessidade de informar os trabalhadores sobre os riscos de sua atividade profissional através de campanhas a serem veiculadas pelos sindicatos. deslocando o interesse desscs para a saúde de scus sindicalizados. Desta forma. a discussão sindical ultrapassaria os limites das campanhas salariais, necessárias mas não suficientes.

Trabalhos de prevenção c promoção de saúde nos Centros de Referência de Saúde do Trabalhador cvitariam o aumento do número de trabalhadoras com esse tipo de lesão.

\section{SUGESTÕES}

A identificação da Lesão por Esforço Repetitivo - L.E.R. - está relacionada com o nivel de conscientização dos profissionais para a relação trabalho/docnça, com a eficiência dos serviços médicos de empresas privadas $\mathbf{c}$ governamentais, com a conscientização do trabalhador e dos seus órgãos de classe. alćm da existência de legislação adequada.

Os meios auviliares de diagnósticos não são específicos. A abordagem da L.E.R. exige cuidados e anamnese que contemple a histónia profissionl, histórico clínico e exame fisico detalhado e cuidadoso.

A evolução da doença pode levar a alterações neuro-músculo-tendinosas irrevesriveis, com a conseqüente impotência funcional. Seu tratamento envolve aspectos médicos e, em um grande número de casos, readaplação funcional.

Nas sociedades altamente industrializadas, como o Japão, por excmplo, ondc existe uma diversificada oferta de funçőes. e onde a massa de trabalhadores apresenta maior qualificaço profissional, o problema da L.E.R., apesar de sua freqücincia, apresenta maior resolutividade.

No Brasil. com limitadas possibilidades na oferta de trabalho, baixa qualificação profissional, ausência de legislaçăo adequada, inopcráncia das instituiçőes oficiais para o estudo e equacionamento das doenças ocupacionais, a situaçăo tende a se agudizar, levando ao aparecimento de uma grande população de incapacitados parcial ou totalmente, com 
violação do próprio direito da cidadania plena, gerando graves problemas de ordem sociocconômica.

Há uma necessidade premente de se montar estudos de revisão dos processos de trabalho, intcrferindo em sua dinâmica e reduzindo os fatores que levam ao aparecimento da doença. No desenvolvimento dessa conduta devem estar presentes os sindicatos, os médicos de empresa e os do serviço público, para em conjunto desenvolverem ações que possam alterar a sombria perspectiva que se apresenta, transformando o trabalho em fator de promoção do homem e não o motivo de sua degradação. 


\section{REFERÊNCIAS BIBLIOGRÁFICAS}

BARDIN, L. (1988). Análise de Conteudo. Lisboa, Ediçðes 70.

BARBIER, R. (1985). A Pesquisa-Ação na Instituição Educativa. Rio de Janeiro, Jorge Zahar Editor.

BARNARD, C. et al. (1982). A Máquina IJumana. Editora J.B.

CRISTENSEN, H. (1986). Muscle Activity and Fatigue in Shoulder Muscles of Assembly Plant Employees. Scan J. Work Environ Healt, 12:582-87.

KROEMER, K. H. E. (1989). Cumulative Trauma Disorders: Their recognition and Ergonomic Measurres to avoid them. Applied Eryonomics, 20:(4), 274-280.

LESÕES POR ESFORÇO DE REPETIÇ̃̃O (L.E.R.). (1991). Nonnas túxnicas para avaliação da incapacidade. Publicado peio Ministério do Trabalho e Previdência Social, Instituto Nacional do Seguro Social, Coordenação Geral de Serviços Previdenciários, Divisão de Rendas Médicas.

LINTON, S. J. \& KAMWENDS K. (1989). Risk Factor in Psychossocial Work Environment for Neck and Shoulder Pain in Secretaries. Joumal of Occupational Medicine, 31(7), p. 609-61 3.

MAEDA,K.(1975). Occupational Cervicobrachial Disorder in Assembly Plant. The Kunumo Medical Joumal, 22(4), p. 231-39.

- (1977). Occupational Cervicobrachial Disorders and Its Causative Factors. J. Human Ergol, 6:193-202.

OHARA, H. et al. (1976). Occupational Jlealth Hazards Resultung From Elevated Work Rate Situations. J. Human Ergol, 5:173-186.

ONISHI, N. et al. (1976). Shoulder Muscle Tenderness and Physical Features of Female Industrial Workers. J. Human Ergol, 5:87-102. 


\section{FARMACÊUTICOS E MÉDICOS: Um Enfoque Antropológico Sobre o Campo de Prestação de Serviços de Saúde em Paulínea}

MARCOS S. QLiERO\%

\section{INTRODUÇÃO}

O contexto mais amplo do presente estudo relaciona-se com o processo de municipalização dos serviços de saúde, presentemente sendo implantado pelo Ministério da Saúde, governos estaduais e prefeituras, através do Sistema Único de Saúde (SUS), e que se encontra num estágio relativamente avançado no Estado de São Paulo. É objetivo relevante deste artigo focalizar as dificuldades que surgem neste processo, principalmente pelo fato de se impor um sistema de saúde desconsiderando os níveis sociais e culturais não só da população envolvida como dos agentes profissionais encarregados de lidar com ela. Neste contexto, o artigo analisa os farmacêuticos, os médicos (da rede pública e privada), ou seja, os principais agentes que constituem o campo oficial de oferta de serviços de saúde em Paulínea, a partir de dados coletados entre 1989 e $1990^{1}$.

Paulínea, situada a 14 quilômetros de Campinas, tem hoje cerca de 40 mil habitantes, tendo sofrido uma intensa transformação socioeconômica a partir da década de 70 , com a instalação de muitas indústrias de grande porte em torno da refinaria da Petrobrás. Hoje, com a grande maioria da população constituída de migrantes, $46 \%$ da populaçāo economicamente ativa do município é empregada no setor industrial e apenas $12 \%$ no setor agrícola.

A riqueza proporcionada pelas suas várias indústrias tem propiciado um nível relativamente alto de investimento do poder público na área social, produzindo um bom

1 Para uma visão mais abrangente do problema, no qual se insere a questāo da estratégia de consumo em saúde, ver Queiroz. M. S. Representações Sobre Saúde e Doença-Agentes de Cura e Pacientes no Contexto do SUDS. Campinas, Ed. Unicamp, 1992. 
nível de prestações de serviços. No que diz respeito à saúde, tendo como referência a média do País, a cidade é particularmente bem-dotada, sendo que praticamente toda a sua população conta com a disponibilidade de serviços médicos gratuitos.

De acordo com a Fundação Seade, a mortalidade infantil (um índice importante para medir o nível de saúde de uma populaçāo) $\mathrm{cm}$ Paulínca era, em 1970, de 114,9/1000. Em apenas dez anos, este índice extremamente elevado despenca abruptamente para 38,9/1000 c continua caindo até atingir 30,3/1000 em 1983, número este que tem sido mantido até 1992. Estes números expressam dramaticamente o impacto no nível de saúde da população produzido por fatores tais como a criação de uma infra-estrutura urbana e de saneamento básico, a formação de uma rede de serviços públicos de saúde e o aumento de poder aquisitivo proporcionado pelas grandes indústrias às massas trabalhadoras.

A metodologia de pesquisa scguiu o parâmetro antropológico que privilegia o aspecto qualitativo e enfatiza a profundidade das informações em detrimento da sua extensão. As entrevistas, com um roteiro aberto, permitindo ao entrevistado expressar-se de um modo pouco dirigido sobre os mais diferentes tópicos de suas atividades profissionais, constituíram a matéria-prima básica para o trabalho de análise. Foram entrevistados, $\mathrm{cm}$ alguns casos mais de uma vez, 14 médicos da rede pública e privada, 14 farmacêuticos ou práticos de farmácia, 4 enfermeiras e 3 atendentes de enfermagem durante $o$ ano de 1990. Além disso, enquanto parte de um projeto maior de pesquisa, 40 famílias de dois bairros de camadas trabalhadoras de Paulínea foram acompanhadas e observadas durante um ano, no que diz respeito às suas representações e práticas referentes à saúde $\mathrm{e}$ à doença. Este acompanhamento, realizado imediatamente antes de iniciar as entrevistas com os agentes institucionais, possibilitou estabelecer uma base sólida sobre os principais problemas do relacionamento desses agentes entre si e entre eles e a população consumidora de seus serviços. O cruzamento das várias entrevistas permitiu distinguir a representação meramente subjetiva daquela que realmente tocava aspectos mais estruturados e objetivos da realidade estudada.

Tcoricamente, esta pesquisa assume que o nível das representaçōes dos profissionais pesquisados são consideradas não como um aspecto secundário da superestrutura social mas, enquanto componente cultural, um aspecto indissociável da infra-estrutura de produção e, portanto, crucial para o rumo e o desenvolvimento futuro de um sistema de saúde a ser implantado no Brasil.

\section{OS FARMACÊUTICOS}

Paulínea conta com 13 farmácias funcionando (sem considerar a do Centro de Saúde que fornece aos clientes alguns medicamentos gratuitos), um número significativo para o tamanho da cidade. Até 1980, havia somente cinco farmácias; as outras oito foram abertas nos últimos dez anos.

Tendo perdido algumas de suas antigas atribuições em função da maior disponibilidade de médicos na cidade, o farmacêutico (encarregado de atender à população nas farmácias) ainda mantém uma importância considerável como agente de saúde, exercendo 
forte influência nas estratégias da população no que diz respeito à saúde e à doença. Além de vender medicamentos, eles oferecem serviços de consulta para diagnóstico e tratamento de doenças, embora não tenham qualquer formação médica ou mesmo farmacêutica. Apesar de reconhecerem que se trata de uma atividade ilegal, nenhum deles demonstrou qualquer receio ou constrangimento em revelá-la e assumi-la de um modo surpreendentemente franco.

Todas as farmácias vendem medicamentos industrializados da medicina alopática, sendo que apenas duas comercializam também medicamentos homeopáticos, porém como uma proporção insignificante de seus negócios. De um modo geral, o farmacêutico se posiciona socialmente como de camada média-alta, frequientemente com elevado prestígio social e político. Os empregados com experiência em diagnóstico e tratamento de doenças são disputados pelo mercado e chegam a ganhar mais de dez salários mínimos por mês.

Por muito tempo, o farmacêutico foi o único agente que intermediava o conhecimento científico oficial com os problemas de doenças da população, uma vez que a presença de médicos era rara e esporádica na cidade. $O$ mais antigo e conhecido deles começou sua carreira em 1945, trabalhando como auxiliar na farmácia de um parente seu. Fez um curso prático de farmácia e atualmente é muito bem-sucedido na profissão.

Por um tempo considerável foi ele a única pessoa com experiência em medicina a estar disponível para cuidar da população. Até recentemente, os médicos vinham de Campinas no máximo duas vezes por semana, faziam as consultas e deixavam-lhe as recomendações para que acompanhasse os casos. Os mais simples, ele mesmo atendia e tratava sem esperar pelos médicos. Desse modo, chegava a consultar uns 60 ou mais pacientes por dia, adquirindo, assim, experiência e se legitimando diante da população. Em nenhuma ocasiāo entrou em conflito com os médicos. Atualmente, Sr. N. reduziu muito suas atividades, embora continue clinicando. A sua farmácia, assim como a de seu filho e sobrinho, as quais contribuiu para estabelecer, atendem uma média de 20 a 25 pacientes por dia cada uma. Apenas duas outras chegam a atender tantos pacientes, uma delas especializada em doenças de crianças e a outra em doenças venéreas masculinas.

Um elemento a unir todos os farmacêuticos num coro comum é a atitude francamente desfavorável, ou mesmo hostil, com relação aos profissionais dos Postos e Centros de Saúde da cidade. Alega-se que esses profissionais esperam demais para efetuar o tratamento, deixando o paciente muito tempo em observação sem medicamento, permitindo, assim, o risco de o caso se agravar. Opondo-se a esta prática, os farmacêuticos procuram satisfazer o cliente examinando minuciosamente o corpo e receitando um número maior de medicamentos, entre estes as vitaminas e outros remédios "populares" repudiados pelos médicos do serviço público.

Investir na confiança do cliente em sua pessoa e em sua prática é uma preocupação constante dos farmacêuticos. Sem essa confiança, não se acredita que haja clima para diagnosticar e tratar qualquer doença. Estar bem relacionado socialmente e conquistar prestígio profissional e social são estratégias que se combinam com esta preocupação. Os farmacêuticos mais tradicionais chegam a alimentar a crença de que são de fato médicos ou quase médicos. A entrevista abaixo ilustra bem a oposiçāo dirigida aos médicos dos Postos e do Centro de Saúde: 
"Estes médicos são incompetentes porque só receitam um tipo de antibiótico (Benzetacil) e AAS para todos os casos. Eles não indicam vitaminas em nenhuma circunstância, o que é errado porque elas ativam ofigado, engrossam o sangue e o indivíduo reage melhor às infecçōes ou à fadiga. As pessoas quando vêm à farmácia reclamam muito dessa situação, principalmente as mäes com crianças doentes. Ninguém gosta de ir ao médico e voltar para casa com o filho doente e uma receita de AAS no bolso. O problema é que eles são quase todos estudantes da Unicamp, mocinhos muito jovens, sem experiência alguma."

"Faço consulta para cerca de $80 \%$ das pessoas que entram na farmácia. Uma boa parte delas é de gente insatisfeita com $o$ atendimento do Posto de Saúde. Muitos clientes já vieram me pedir para dar queixa ao prefeito. mandar esses médicos embora, mas não posso fazer nada sozinho. É por causa disso que Paulínea tem 13 farmácias e o movimento delas, mesmo com essa crise econômica, só vem aumentando."

"Eu não dou palpite com os remédios receitados pelo Posto, mas se o cliente quiser que eu consulte, rasgo a receita e faço nova consulta. Também não influencio o paciente na sua decisão de adquirir os medicamentos receitados pelos médicos. Para isso, tenho um grande estoque de AAS, porque é só isso que eles sabem receitar. Se um paciente estiver muito mal. eu o mando para o Posto porque não quero assumir responsabilidade. Muitas vezes, este paciente volta indignado com a receita de AAS que lhe passaram. Dai eu tenho que atendê-lo de qualquer jeito."

Com relação aos médicos particulares da cidade, os farmacêuticos em geral mostraram uma atitude favorável, principalmente com o Dr. R. (ver entrevista na próxima seção), que é considerado um excelente médico. Já o relacionamento dos farmacêuticos com os colegas de profissão mostra uma intensa rivalidade e competição pelo prestígio da clientela. A suspeita sobre a honestidade do trabalho dos demais ocorre freqüentemente, no que se refere à prática de empurrar para o paciente o maior número possível de remédios, principalmente aqueles mais lucrativos provenientes de laboratórios menos conhecidos. Quase todos os farmacêuticos se acusam mutuamente de recorrer a este expediente inescrupuloso. Ao mesmo tempo, eles consideram a sua prática como honesta e séria, uma exceção num ambiente perverso onde o lucro se realiza às custas da saúde da população. A entrevista abaixo é reveladora dessa prática:

"Eu não tenho vantagem nenhuma de trabalhar honestamente, pelo menos, até agora não tive. Sei de muitos balconistas que substituem os remédios de laboratório confiável receitados pelo médico por um similar com nome parecido. 
Por exemplo, Bactrim se transforma em Bacectrim, e para cada Bacectrim comprado pela farmácia, o farmacêutico ganha outro grátis do laboratório farmacêutico. É comum os donos da farmácia pagarem $20 \%$ do preço do remédio para o balconista que consegue empurrar tal medicamento. Uma pessoa instruída pode não cair neste conto, mas a população mais pobre é lograda com facilidade. Quase todos os farmacêuticos em Paulínea usam essa prática. Seria bom se os médicos dos Postos pudessem prevenir a população a respeito dessa situação e colaborassem escrevendo as receitas com letra mais legivel para dificultar o logro."

De um modo geral, o declínio da profissão de farmacêutico, enquanto consultor sobre tratamento de saúde, tende a ocorrer em todo lugar onde se verifica a presença de médicos e de um sistema organizado e eficiente de saúde. A industrialização cada vez mais intensa dos medicamentos significa um fator adicional a restringir o papel do farmacêutico ao de um mero vendedor de remédios, ou um homem de negócios, ao invés de um agente de tratamento e cura de doenças legitimamente reconhecido como tal.

A partir dessa constatação, é de se supor que as modificações sociais e econômicas em curso em Paulínea apenas iniciaram as transformações que levariam o farmacêutico a ser privado de seu papel tradicional de agente de cura. É, nesse sentido, tentador explicar a persistência desse papel com o fato de que os profissionais mais conhecidos e procurados exercem a sua atividade por muito tempo na cidade, tendo adquirido grande respeito e consideração por parte da população. Nesse contexto, o seu papel seria mantido como sobrevivência de uma manifestação tradicional que tenderia a se extinguir naturalmente quando os farmacêuticos mais conceituados se aposentarem. Ou ainda, quando novos hábitos, relacionados com a verificação de que médicos são mais competentes para lidar com problemas relacionados com saúde e doença, se fortaleçam entre a populaçāo. Segundo essa hipótese, não haveria como uma prática tradicional, contrária à moderna organização do serviço médico, que efetivamente ocorre na região, possa conseguir sobreviver.

No entanto, temos razões para pensar que a situação apontada acima é insuficiente para explicar o que de fato ocorre com os farmacêuticos em Paulínea. Nada indica, por exemplo, que a população deixará de recorrer a eles quando aqueles mais tradicionais se aposentarem. Pelo contrário, alguns dos mais novos já são procurados pela populaçāo, sugerindo que efetivamente ocorre um processo de treinamento e substituição dos mais antigos.

\section{OS MÉDICOS}

Como vimos, até recentemente, médicos particulares vinham esporadicamente uma ou duas vezes por semana para atender à população, sempre em sintonia e em aliança com os farmacêuticos da cidade. Já os médicos da rede pública se introduziram no município a 
partir de 1973, quando o Centro de Saúde foi fundado, mas só tiveram uma presença mais ampliada a partir de 1983, quando a rede passou a funcionar com a sua estrutura atual.

Antes desse período, tentativas de alguns médicos liberais de se estabelecerem definitivamente na cidade ocorreram, mas em geral sem sucesso. $O$ fato de Paulínea estar tão próxima de Campinas, um centro urbano regional importante em grande expansão, inclusive com uma medicina adiantada em muitos aspectos, inibia o estabelecimento de médicos na cidade, o que só veio a ocorrer a partir do desenvolvimento industrial experimentado pelo município.

\section{OS MÉDICOS PARTICULARES}

Paulínea conta atualmente com nove médicos particulares exercendo medicina liberal ou autônoma, sendo que apenas um é plenamente estabelecido em tempo integral. Este último, Dr. R., clinicando na cidade desde 1978, usufrui grande prestígio diante da população e domina a medicina privada no município, na medida em que emprega em seu hospital quatro outros médicos em período parcial. $\mathrm{O}$ time comandado por ele responde por aproximadamente $80 \%$ do total das consultas oferecidas pela rede privada. $O$ início da sua carreira coincidiu com o acelerado desenvolvimento econômico e social experimentado pelo município, que produziu uma classe operária e uma classe média consumidora de bens e serviços médicos.

O hospital do Dr. R é mantido principalmente por convênios com várias indústrias de Paulínea, compreendendo cerca de 1.600 funcionários mais os dependentes, o que perfaz aproximadamente seis mil clientes potenciais, fora as consultas particulares que, no entanto, nāo são muito significativas. Abaixo, trechos de sua entrevista mostram a sua maneira de encarar o seu papel, assim como a visão que tem dos problemas da populą̧ão e do município.

"A minha prática segue uma tendência completamente diferente daquela do serviço público. Eu medico logo o paciente para ele ficar tranqüilo, ao invés de esperar uma reação ou uma melhora, como costumam fazer os médicos do setor público. Qualquer pessoa se sentiria muito melhor sabendo que, por exemplo, seu filho já está medicado e que a cura é só uma questão de tempo. Um outro ponto importante é a questão das vitaminas. Os médicos dos Postos de Saúde em hipótese alguma receitam tal medicamento e eu discordo dessa postura. Algumas pessoas, em alguns momentos da vida, por motivos vários, precisam de um reforço vitamínico. Muitos pacientes saem dos Postinhos insatisfeitos, passam na farmácia para se consultar com o farmacêutico e pegar uns remédios adicionais. Outros preferem pagar uma consulta comigo e ficar tranqüilos de que estão medicados. De qualquer modo, estes médicos não constituem concorrência 
para o meu serviço, uma vez que eu não teria como atender um número maior de pacientes.

"Um outro motivo que faz com que muitas pessoas me procurem é o fato das minhas consultas serem bem familiares $e$ informais. No Centro e Postos de Saúde, os médicos sempre mudam e o paciente acaba não sendo conhecido. No entanto, eu, que já vivo em Paulínea há mais de dez anos, conheço todo mundo, sei dos problemas das pessoas e da comunidade. Os pacientes acham muito importante uma atenção simpática, o que eu sempre procuro fazer. Se um médico souber conversar e ouvir o que ele tem a dizer, ganha imediatamente a sua confiança. Os pacientes sentem muita falta de um contato mais direto e pessoal, além de fazerem questão de um exame minucioso do corpo. Mesmo sabendo de antemāo o problema, examino tudo: olho, ouvido, garganta, pressão e peito. $\mathrm{Na}$ maioria das vezes, trata-se apenas de um teatro para ganhar a confiança do paciente e conseguir que ele se tranqüilize. Às vezes, os pacientes insistem em fazer exames desnecessários $e$, se eles estão dispostos a pagar, eu os faço porque, para o tratamento ser bem-sucedido, $e$ importante o paciente ter confiança no médico.

"Quanto aos farmacêuticos, mantenho com eles um relacionamento baseado no respeito. Há uns anos, eles desempenhavam o papel de médico. Hoje, eles vão até um certo ponto $e$ depois mandam os pacientes para o médico, geralmente para mim. As pessoas me contam que vão à farmácia se consultar e eu acho normal, desde que ofarmacêutico seja responsável. Eles também não chegam a constituir concorrência ao meu serviço porque eu não teria como dar assistência a todos os que os procuram diretamente.

"Ao contrário dos médicos da rede pública, eu não costumo falar mal de ninguém, um fato que geralmente meus pacientes admiram. Muitos deles, quando são obrigados a usar o serviço público por qualquer motivo, me contam que os médicos de lá só sabem me criticar. Às vezes, gastam toda a consulta falando mal de mim. Considero isso falta de ética profissional. $O$ sistema de saúde deve ser composto de instituiçōes públicas e particulares e umas e outras não têm que ficar se criticando." 


\section{OS MÉDICOS DO SETOR PÚBLICO}

Paulínea conta com um hospital, um Centro de Saúde e três Postos de Saúde. O Centro de Saúde, que começou a funcionar em 1973, apresenta um serviço de maior complexidade, tanto em nível das relações de trabalho internas como no de aparelhos diagnósticos. Nos Postos, os únicos aparelhos mais complexos que podem ser encontrados são os odontológicos.

O hospital, fundado em 1983, passou a fazer parte da rede pública administrada pela prefeitura e pela Unicamp, com a função de trabalhar na retaguarda dos Postos e Centro de Saúde. Segundo a avaliação dos médicos do setor público, o hospital é hiper-sofisticado, com 100 leitos, um exagero para uma cidade do porte de Paulínea.

Em princípio, todos devem fazer suas consultas no próprio bairro de residência ou no Centro de Saúde se nele for cadastrado e, depois, caso necessário, devem ser encaminha-dos para o hospital. Dentro dessa perspectiva, o Pronto-Socorro só serviria para casos de urgência. No entanto, sabe-se que esta é uma situação apenas ideal, sendo que na prática o Pronto Socorro atende diretamente todos aqueles que o procuram. Calcula-se que cerca de $40 \%$ deste atendimento são de pessoas de fora da cidade que não contam com serviços adequados em seu local de origem. Embora insatisfatória, não tem sido possível encontrar uma solução prática alternativa a esta situação.

Em média, o hospital apresenta 250 internações e o Pronto-Socorro atende 5.000 casos por mês. $O$ gasto aproximado, segundo o diretor técnico-administrativo do Hospital Municipal, é de 100 mil dólares mensais. Este mesmo diretor revela também que o hospital não dispōe de uma planilha que demonstre tanto os gastos como os recursos financeiros que entram pelos convênios (através de empresas várias, prefeitura e Ministério da Saúde), o que demonstra uma prática gerencial empírica e um estado grave de desorganização administrativa. A consciência da necessidade de um sistema gerencial está presente, no entanto, em iniciativas recentes, visando a um convênio com a Faculdade de Medicina da Unicamp.

Para se entender as representações e as práticas dos médicos do setor público de Paulínea com respeito ao serviço e à clientela, transcreveremos abaixo trechos de entrevistas realizadas com três médicos, uma enfermeira e uma atendente de enfermagem. A primeira entrevista é com Dr. A., talvez o único que possa chegar perto em popularidade do Dr. R., o médico particular entrevistado anteriormente. Dr. A., 30 anos, atende na clínica médica do Centro de Saúde há sete meses, depois de ter passado cinco anos prestanto serviços num dos Postos de Saúde. Trabalha só de manhã em Paulínea, e à tarde, em suas palavras, "ganha a vida" trabalhando em outros locais, em alusão ao baixo salário que recebe no setor público. Em suas palavras,

"O atendimento da rede pública de serviços de saúde em Paulínea é considerado modelo. Muitos profissionais de fora vêm nos visitar para ver como funciona e fazem muitos elogios. Apesar de algumas falhas, realmente há um bom atendimento, mas só para aqueles pacientes que se encaixam dentro do aparato técnico com o qual o médico está acostumado a lidar. Os que não se encaixam dentro das "doenças 
tradicionais", a maior parte dos casos, são mal atendidos. A maioria dos pacientes têm o que denomino "sindrome do migrante", ou seja, dor no peito, enxaqueca, problemas estomacais, tudo isso fruto de somatização de problemas de origem social. Para tratá-los seria necessário muito "batepapo" e compreensão. Infelizmente, a maioria dos médicos têm formação técnica na área biologica e pouquíssima base em psicanálise e assuntos sociais.

"Os migrantes, que constituem a grande maioria dos clientes, têm uma histbria que não pode ser esquecida quando entram num consultorio médico. Tanto essa história como a situação que estão passando no presente se refletem em seus quadros clínicos. É esse aspecto que sempre tentei introduzir na minha prática médica. No entanto, infelizmente, a estrutura do atendimento não dá condições para esse tipo de proposta, o que causa muitos conflitos com a populaçâo."

A nossa concepção de saúde e doença, que se relaciona com a questão socioeconômica maior, não pode ser inculcada nas mentes dos pacientes do dia para a noite. Se o médico diz que o paciente nāo tem nada, quando diz sentir dor no peito ou qualquer outro sintoma, ele vai procurar um médico particular ou um farmacêutico, que estão sempre dispostos a concordar com ele e a lhe dar "soluçōes" para o problema. Às vezes, o médico nem diz que o paciente nāo tem nada e, pelo contrário, tenta explicar que é uma somatização ou que é um distúrbio comum, contra o qual o próprio organismo se defende, sem necessidade de remédios. Mas não é ouvindo isso que o paciente vai se conformar e jogar fora um modo de pensar tão enraizado. Isso só pode ser mudado através de um longo processo de educação.

"Eu discuto muito com meus colegas essas questões, mas a maioria fica irritada quando um paciente traz uma receita do Dr. R. e pergunta se "está certa". ou quando alguém já passou pelas mãos de um farmacêutico e se medicou de maneira inapropriada. Apesar de entender a atitude dos colegas, não vejo sentido em se irritar com o paciente. No fim, nós acabamos virando os vilões da história.

"Hoje em dia, eu faço algumas concessões à população como, por exemplo, receitar algumas vitaminas quando o paciente pede. Eu receito por umas duas semanas $e$ mando parar depois dizendo que elas podem intoxicar. Nas primeiras vezes que fiz isso me senti muito mal, não consegui nem mesmo dormir à noite porque sabia que estava reforçando uma situação ou um hábito que contraria o bem-estar da populaçāo. Hoje, eu acho isso natural, uma vez que dá confiança ao paciente. Trata-se de uma concessão muito pequena que 
me ajuda a manter o tratamento sob controle. Porém, meus colegas me criticam muito por isso.

"Não posso negar que essa minha atitude acabou criando um lado negativo, uma vez que muita gente passou a me procurar so para conversar porque estava deprimido, porque não dormiu à noite ou porque brigou com o vizinho. Muitos criaram dependência em relação a mim e foi por isso que saí do Posto de Saúde e mudei para o Centro de Saúde.

"Quanto ao Dr. R., o médico particular da cidade, apesar do seu prestígio, o considero muito pouco sério porque, diante da pressão dos clientes, costuma utilizar um excesso de medicamentos fortes $e$ desnecessários, o que pode trazer muitos problemas à saúde."

A segunda entrevista foi realizada conjuntamente com a médica Dra. M. e com a enfermeira, Sra. S., ambas de um dos Postos de Saúde do município. Selecionamos os trechos de suas entrevistas que melhor refletem as representaçōes da grande maioria dos médicos da rede pública de Paulínea.

"O nosso procedimento de evitar um excesso de medicação faz parte de uma visāo de medicina preventiva e de saúde pública influenciada pela Faculdade de Medicina, que gerencia a rede básica de serviços de saúde de Paulínea. Sabemos que muitos clientes voltam para casa insatisfeitos com esse procedimento e se medicam por conta propria. Não é fácil para o Posto conseguir sozinho mudar a mentalidade das pessoas, tão manipuladas pela força da indústria farmacêutica. Nas consultas, essas coisas não são explicadas pelo médico, o que talvez seja um erro, mas provavelmente esse tipo de explicação não adiantaria muito.

"O relacionamento com os farmacêuticos, apesar de ter melhorado muito, ainda é tenso. Eles se sentiram ameaçados com a chegada de tantos médicos da rede pública. Como estes receitavam poucos remédios, eles passaram a se sentir boicotados. Houve, há um tempo atras, uma briga feia entre um deles e uma das enfermeiras aqui do Posto, que criticou abertamente o tratamento inadequado de um farmacêutico. Sabendo do ocorrido, este entrou no Postinho aos gritos, xingando a enfermeira no meio de todos. Infelizmente, ela acabou sendo demitida por causa disso.

"O relacionamento com os médicos da rede privada, quer dizer, com o Dr. R., é ainda mais tenso e conflituoso. Enquanto os médicos da rede preocupam-se em não medicar desnecessariamente, este médico é especialista em receitar 
antibióticos e remédios fortíssimos para casos muito simples. No entanto, nada se pode fazer contra ele.

"Os casos de doenças mais freqüentes encontrados no Posto sāo as varias doenças infantis corriqueiras e os reflexos da pobreza, da preocupação com a falta de dinheiro, com $o$ marido desempregado ou com o filho que anda com más companhias. Essas últimas condições manifestam-se através de vários sintomas, tais como dores e mal-estares em geral. $E$ incrível o número de pessoas com pontadas no peito, sintoma comum de angústia, que pedem para fazer exames de coraçāo. É comum também um tipo de paciente crônico que não sai do Posto. Geralmente são mulheres que vêm por causa de dores "misteriosas" ou mäes desesperadas porque o filho amanheceu com febre, dor-de-barriga ou qualquer outro motivo sem importância. As pessoas que têm alguma doença "de verdade" ficam satisfeitas com o nosso serviço."

A terceira entrevista é com o Dr. D., do Centro de Saúde, que abordou de um modo ainda mais crítico o relacionamento dos médicos da rede pública com a comunidade.

"Uma coisa que eu faço absoluta questão é que o paciente siga o tratamento de um modo consistente com um mesmo agente por um certo período de tempo, seja ele farmacêutico, curandeiro, médico da rede pública ou privada. No entanto, a maioria dos pacientes recorrem a vários tipos de agentes de diferentes tipos ao mesmo tempo e acabam não seguindo direito nenhum tratamento. Isso é um transtorno antiprodutivo e antieconômico.

"É comum pacientes virem ao Posto dizendo que estavam tomando um comprimido colorido e um xarope branco amargo receitados pelo Dr. $R$. ou por um farmacêutico. Em outros casos, mães ansiosas correm com os filhos para um farmacêutico depois de serem atendidas no Posto e voltam para casa com outros remédios, misturando tudo. Não é raro encontrar d tarde, esperando atendimento no Pronto-Socorro, alguém que já atendi de manhā.

"Nós não temos como lidar com esse tipo de problema porque não há qualquer possibilidade no momento de implantar um sistema de controle que credencie o paciente a utilizar com exclusividade um determinado Posto de Saúde. Com isso, perde-se completamente o significado do tratamento, tornando impossível reconstituir qualquer uma das etapas do desenvolvimento da saúde e da doença. 
"Quando se começa a trabalhar num emprego como esse, é lógico que existe um ideal, uma vontade de desenvolver um trabalho de educação na comunidade. Mas se acontecer de você mandar um paciente para casa com um AAS e ele tiver um enfarte e morrer naquele dia, a comunidade inteira irá responsabilizá-lo. Se eu chegar atrasado amanhä por qualquer motivo, o bairro inteiro fica sabendo uma hora depois. Tem periodos em que a gente está todo animado, mas tem hora em que nāo quero nem olhar para a cara de um colega ou de um paciente, nem quero ouvir falar de Posto."

A quarta entrevista é com a Sra. V., atendente de enfermagem, 50 anos, primário incompleto, uma das pioneiras que contribuíram para a implantação dos Postos de Saúde em Paulínea que, com desenvoltura, fala sobre os vários problemas da rede no seu convívio com a comunidade.

"Não concordo com a forma como os médicos tratam os pacientes. Como a maioria deles é pobre, se alimenta mal e tem um nivel de vida baixo, não custa nada ser um pouco mais atencioso. Essas pessoas adoram exames e näo custa pedir um exame de fezes ou de sangue. Sempre se descobre algo e o paciente vai para casa feliz, sem ouvir aquele "vocênão tem nada". Existem várias coisinhas pequenas que podem ser feitas para contornar situaçōes dificeis. Nâo sei dizer quantas vezes já dei água-com-açúcar ou com algumas gotos de uma substância colorida para pacientes, só para acalmá-los. Mas os médicos não sabem fazer isso. Muitas pessoas fazem consulta e saem inconformadas com a atitude do médico. Ficam desconsoladas, nervosas, vão para a rua e, dali a pouco, procuram o farmacêutico para uma outra consulta.

"Um outro ponto é que a maioria dos médicos é jovem e não usa roupa branca. Os pacientes acham estranho ser atendido por uma moça de minissaia ou um moço barbudo de camiseta. Eu cheguei a fazer essa observação numa reunião no Centro de Saúde porque muitas pessoas do bairro já tinham comentado comigo. A minha proposta foi votada mas perdeu com muitos votos de diferença.

"Também estou de acordo com as críticas aos residentes da Unicamp. Acho que as coisas acontecem de um modo que provoca a insegurança do doente. $O$ residente examina, diz qual é o problema e chama o docente. $O$ docente ouve, concorda ou discorda e vai embora. Se o médico olhasse o doente, juntamente com o estudante, desse orientação e depois saísse, não haveria tanta desconfiança. Além disso, a 
rotatividade dos residentes é muito alta. As pessoas não têm tempo de se acostumar com eles.

\begin{abstract}
"Acho que os médicos e enfermeiras mais novos deveriam dar ouvidos a pessoas experientes como eu que, apesar de näo terem muito estudo, têm contato direto com a população que utiliza o serviço. Infelizmente não posso dizer o que penso porque sou só uma atendente. Eles acham que estâo certos agindo como agem e depois ficam se pergurtando porque $o$ povo vem se afastando do serviço".
\end{abstract}

\title{
DISCUSSĀO
}

No interior do contexto da política de municipalızaçăo dos serviços de saúde, o presente estudo focaliza uma situação que é considerada bem-sucedida no Estado de São Paulo. No entanto, observa-se que as reformas administrativas implementadas não foram acompanhadas de um método de avaliação e controle do sistema de saúde que possa auxiliar a administração do sistema a lidar com seus muitos problemas. OSUS necessita estabelecer políticas especificas para o desenvolvimento de novas práticas gerenciais que, por sua vez, devem considerar os aspectos socioculturais relativos à comunidade e às profissões da saúde. Ao trazer alguma luz sobre as representações, o papel social, as ideologias e práticas dos principais produtores oficiais de saúde em Paulínea, os médicos e os farmacêuticos, este estudo espera poder contribuir para a geração de conhecimentos que certamente poderão influenciar positivamente a política de saúde e o gerenciamento do sistema.

O conjunto das farmácias apresenta várias analogias com a medicina particular em Paulínea. Ambas se encontram sintonizadas com os interesses mais imediatos da poderosa indústria médico-farmacêutica e se organizam segundo os moldes capitalistas, no qual o lucro é um fator fundamental. Ambas estão também envolvidas na tentativa de cativar o paciente através do uso de símbolos sociais relevantes e prover uma abertura emocional para suas ansiedades e demandas, ponto esse a que a medicina do setor público tem se mostrado insensível. Enquanto os médicos da rede privada e os farmacêuticos tendem a aceitar plenamente a condição auto-imposta de doente por parte do paciente, medicando mesmo quando sabem que ele nāo apresenta morbidade alguma, os médicos do serviço público tendem a não medicar quando percebem que a solução do caso não depende de medicamentos.

A rede pública municipalizada de serviços de saúde em Paulínea e as especificidades de sua prática médica (em vários aspectos, afastada do centro de influência da medicina capitalista dominante no Paf́s) sāo fenômenos relativamente novos no contexto brasileiro que contrariam as seguintes dimensões: a cultura da excelência tecnológica de medicamentos industrializados no tratamento de doenças, cultura esta profundamente arraigada na população através da propaganda; a prática dos médicos particulares que têm interesse em difundir esta cultura; $e$, principalmente, o interesse dos farmacêuticos em vender medicamentos. Nesse contexto, os médicos do setor público deixaram de representar uma 
versão médica funcional a vários interesses do sistema socioeconômico dominante. Portanto, temos em Paulínea uma situação em que aspectos tradicionais representados pelo papel desempenhado pelo farmacêutico se adaptam no sentido não só de servir como expressar a medicina capitalista dominante.

De acordo com a visão de mundo dos médicos da rede pública, três grandes obstáculos dificultam o seu desempenho profissional. Primeiro, está a medicina organizada em moldes considerados inescrupulosamente capitalistas, que concorre e compete com os serviços públicos; segundo, a incapacidade do setor público de controlar a clientela com referência a um Posto ou Centro de Saúde exclusivo; terceiro. a falta de educação, ou educação inadequada da grande maioria da população que, movida pela propaganda, revela um comportamento fortemente inclinado em direção a uma medicina baseada em soluções tecnológicas complexas e a uma supermedicalização.

Com respeito ao caráter capitalista da medicina, os médicos do Centro e dos Postos de Saúde pouco podem fazer, a não ser procurar desenvolver uma atitude didática no sentido de "politizá-la", como mencionam alguns, ou "conscientizá-la", como preferem outros. "É preciso ensinar esta população a se defender, inclusive, da própria medicina", como diz um dos médicos do Centro de Saúde ao ser entrevistado. Evidentemente esse ideal educativo não se faz sem se defrontar com vários problemas.

O problema maior resume-se no fato de que, segundo a própria estimativa dos médicos da rede pública, cerca de $80 \%$ dos casos clínicos que chegam até eles são problemas de ordem social que são somatizados em dores ou indisposições não-passíveis de serem tratadas via medicamentos ou cirurgias. Este problema parece ser universal e não restrito a Paulínea. Na Inglaterra, por exemplo, há estudos indicando que aproximadamente $60 \%$ dos casos que aparecem para os médicos não podem ser tratados adequadamente por serem problemas de ordem psicológica ou social que extrapolam a competência do serviço ${ }^{2}$.

Não deixa de ser um paradoxo o fato de os médicos da rede pública, que consideram como extremamente importantes aspectos sociais e econômicos na origem e na manifestação de doenças, não utilizarem esse mesmo parâmetro no tratamento e na cura. A nãomedicação, o não-uso de roupas brancas e o não-emprego de símbolos socialmente significativos como, por exemplo, a exibição de aparelhos complicados tecnologicamente são aspectos dessa atitude que desconsidera o lado simbólico como parte importante no processo da cura.

Ao manter essa atitude insensível à cultura da comunidade, os médicos da rede pública de saúde correm o risco de serem considerados incompetentes para diagnosticar e tratar doenças. Ao ceder a esse tipo de tentação, por outro lado, eles correm o risco de se compromissarem com interesses alheios a uma prática baseada numa ciência imparcial. Assim, esses médicos devem muito provavelmente continuar a conviver com este dilema ainda por um bom tempo. 


\title{
TERAPEUTAS CORPORAIS NO RIO DE JANEIRO: Relaçōes entre Trajetória Social e Ideário Terapêutico
}

\author{
JNE A. RLSSO
}

Este trabalho é parte de uma pesquisa mais ampla acerca do surgimento e florescimento das terapias corporais na cidade do Rio de Janeiro, movimento que ocorre a partir do final dos anos 70 e durante os anos 80 , e que se situa no bojo da difusão de uma "cultura psicológica" entre as camadas médias urbanas da população. O início dessa difusão é marcado pelo boom psicanalítico dos anos' 70 .

Inicialmente é necessário esclarecer que as "terapias corporais" fazem parte do campo das terapias "psi". Sua característica básica é a crença de que queixas e mal-estares normalmente classificados como "psicológicos" localizam-se no corpo e devem ser tratados a partir de exercícios e atividades corporais. Ou seja, partem do princípio de que o psicológico é corporal.

Originam-se, em maior ou menor grau, da teoria de Wilhelm Reich, psicanalista expulso da Associaçāo Psicanalítica de Berlim, em 1934, devido às suas desavenças com a doutrina oficial. Compreendem desde as terapias efetivamente criadas por Reich (vegetoterapia caracteranalítica e orgonoterapia) até as chamadas práticas ou terapias neo-reichianas, como a bioenergética, a biossíntese, a massagem biodinâmica, etc ${ }^{*}$.

Ligam-se, especialmente em seus primórdios, a um movimento mais amplo de crítica e desafio aos costumes e comportamentos ditos tradicionais - a contracultura dos anos 60 . Surgem, entāo, temas que se revelarão centrais no posterior desenvolvimento do ideário das terapias corporais: a liberação do corpo e da sexualidade, a crítica à sociedade "repressora", a busca de autenticidade e espontaneidade, etc. No campo "psi", afirmam-se como alternativas às práticas já consagradas e aceitas como "oficiais" (sobretudo a psicanálise), criticando seu "intelectualismo", "elitismo" e "conservadorismo"** .

* E importante frisar que, embora as terapias criadas por Reich sejam cronologicamente anteriores, o movimento das terapias corporais que surge nos anos 70 é sobretudo neo-reichiano (ou pos-reichiano), havendo, a partir das novas terapias, uma redescoberta de Reich e das técnicas por ele criadas.

* Segundo Robert Castel, as terapias corporais e demais terapias alternativas surgem, na verdade, a partir do sucesso e da difusāo da psicanálise, isto é, sāo parte dessa difusăo, retendo, inclusive, parte da mensagem psicanalítica (Castel, 1987). 
Vou tratar aqui do surgimento de uma ocupação ou de um grupo ocupacional - os terapeutas corporais - dentro do campo das profissões "psi". Meu objetivo é estabelecer relações entre o surgimento ou a criaçāo dessa nova atividade "psi" e a história de vida (e, portanto, a trajetoria social) dos sujeitos responsáveis por esse surgimento. Para tanto, procuro demonstrar a afinidade existente entre o ideário das terapias corporais e a trajetória desses sujeitos*.

Antes de passar à discussão propriamente dita, porém, gostaria de me deter um pouco na relação entre trajetória social ascendente em camadas médias e a questão do florescimento de uma "cultura psicológica" "*

"Subir na vida" está longe de significar apenas sucesso material ou financeiro. $\mathrm{O}$ distanciamento físico, geográfico do meio de origem é inevitavelmente acompanhado por um distanciamento simbolico, isto é. pelo abandono de determinados paradigmas e orientações por outros. A mobilidade ascendente é uma situação de ruptura com um universo de valores tradicional, no qual se enfatiza a repetição, a permanência, o lugar pré-determinado do sujeito no grupo, a manutenção dos códigos hierárquicos desse grupo etc. Ascender socialmente, portanto, envolve, para além do aspecto puramente financeiro, uma mudança de mundos. Mais do que isso, muitas vezes a "mudança de mundos" é tão crucial que acaba sendo vivida como o próprio objetivo da mobilidade. A trajetória ascendente (o "subir na vida") dentro desse quadro, torna-se, para o sujeito, algo que é fruto de seu desejo de mudança. Mudança que, por isso, passa de externa para interna, passando a significar uma transformação radical do próprio sujeito. As teorias e práticas "psi" fornecem a essas pessoas obrigadas a "mudar de mundos" o sentido e a direçāo de uma tal "mobilidade interior"

\section{OS TERAPEUTAS CORPORAIS}

A característica mais marcante da história de vida dos sujeitos entrevistados é a mobilidade geográíca e sociał com relação à família de origem. A mobilidade ascendente era buscada através do diploma universitário. Com apenas duas exceçōes, nenhum dos sujeitos pesquisados tinha pai ou mãe com diploma superior. Tratava-se, portanto, de buscar alguma coisa que faltava à família de origem e, com isso, mudar seu próprio destino social. Por outro lado, estudar significava, na maior parte dos casos, distanciar-se fisicamente do universo de origem. Dos vinte terapeutas pesquisados, apenas seis são naturais do Rio. Alguns vêm de pequenas cidades do interior, outros de cidades localizadas na periferia do Rio de Janeiro.

* Procurei entrevistar todos os responsáveis pela introdução das terapias corporais no cenário "psi" carioca. Dos prováveis 17 pioneiros entrevistei 12. Entrevistei ainda oito terapeutas que, embora não fazendo parte do grupo pioneiro, foram responsáveis pela criaçâo de instituiçôes de formaçăo em terapia corporal.

* Lembramos a associação frequente entre o boom psicanalítico dos anos $70 \mathrm{e}$ o "milagre econômico". A discussão que se segue é grandemente inspirada nos trabalhos de Gilberto Velho (Velho, 1975, 1981 e 1986) e de outros autores que trabalharam com camadas médias, em especial Tania Salem (ver sobretudo Salem, 1987).

Para uma discussão mais detalhada desse argumento, ver Russo, 1992:52-60. 
Mesmo para aqueles vindos de outra grande cidade, permanece a idéia de um "descentramento": dois dos pioneiros vindos de São Paulo são filhos de estrangeiros que deixaram seus parses de origem para escapar de conflitos armados.

Mais do que um movimento de baixo para cima. a mobilidade dos sujeitos me pareceu consistir num deslocamento da margem (periferia) para o centro. Margem geográfica e social. Todos os sujeitos pertencentes ao núcleo pioneiro vêm de famílias com poucos recursos financeiros. Os pais são pequenos comerciantes, funcionários públicos, havendo mesmo um pequeno lavrador e um motorista de praça, todos com primeiro ou segundo grau. A crença da escolaridade como forma de ascensão social aparece nesse universo de camadas médias inferiores como o que propulsiona a mudança, sendo acalentada e incentivada pela família de origem. Neste sentido, os sujeitos, ao se distanciarem e mesmo romper com o universo de origem, seguem uma espécie de inclinação familiar. A intenção de "progredir" estava em sintonia com o projeto dos pais. Ao mesmo tempo, esse impulso de mudar, ir embora, deixar a periferia pelo centro, galgar posições na escala social, alia-se a uma razoável dose de indeterminaçāo.

Se os sujeitos se viam de alguma forma empurrados para longe do universo de origem, a inclinação que os empurrava nada mais era do que isso: uma inclinação. As indicações do que fazer para "chegar lá" - e até mesmo onde era o "lá" - eram vagas e pouco precisas. A expectativa de que os fithos seguissem um curso superior, por exemplo, era genérica e pouco clara quanto à carreira a ser seguida. Pode-se dizer que a mensagem básica da família de origem era tão somente: "sejam diferentes de nos", como se ser diferente fosse algo a ser decidido (ou construído) pelos próprios sujeitos.

É evidente, entretanto, que a indeterminação não é total. Muitas alternativas de carreira estavam desde o início excluídas das possibilidades do grupo. Sabemos que a escolaridade não funciona automaticamente como mecanismo promotor de ascensão social, devendo se combinar com um certo grau de capital cultural de origem e/ou capital social ${ }^{*}$. Isto é, o sucesso através da escola nem sempre depende do que se aprende nela, mas exatamente daquilo que ela não fornece ${ }^{* *}$. É isto, este "algo mais" que não se encontra na escola, que o grupo em questão teve que compensar.

Uma das formas de driblar uma possível exclusão foi deixar-se atrair por profissões cuja indeterminação não implicasse em qualquer exclusão a priori, como a psicologia. No caso da medicina, explorar exatamente seus pontos de indeterminação, voltando-se para as chamadas "medicinas alternativas" ou para, no interior da psiquiatria, práticas psicoterápicas novas e pouco estabelecidas - campos que, por estarem em expansão e serem relativamente marginais, tendem mais a incluir recém-chegados do que a excluir.

* Uso aqui as definições de Pierre Bourdieus tais como aparecern em La Distinction.

* Sobre isso vale a pena citar Bourdieu: " Eximindo-se de oferecer a todos explicitamente o que exige de todos implicitamente, quer exigir de todos uniformemente que tenham o que não lhes foi dado, a saber, sobretudo a competência lingüística e cultural e a relação de intimidade com a cultura e com a linguagem, instrumentos que somente a educaçāo familiar pode produzir quando transmite a cultura dominante." (Bourdieu, 1974:306-307). 
A psicologia e as especialidades "psi", de um modo geral, parecem possuir uma grande afinidade com a indeterminação estrutural presente na história de vida dessas pessoas".

A partir da escolha de uma área de razoável indeterminação e baixa taxa de exclusão, o grupo inventa uma ocupação. Uma ocupação cuja ligação com um diploma superior é tênue e pouco definida e cujas exigências paralelas à formação escolar também são pouco claras ou inexistentes. Trata-se de inventar uma ocupação no sentido de inventar as regras de acesso à mesma, bem como os critérios de avaliação dos que a praticam.

Os sujeitos pesquisados, entretanto, não inventam apenas uma profissão. Todos "se fazem" através de muita batalha, praticamente sem ajuda da família. Mais do que uma profissão, são pessoas que inventaram a si mesmas: o processo de construção de uma nova profissão (de terapeuta corporal) se entrelaça a uma espécie de processo de autoconstrução. Lembro aqui que estamos lidando com sujeitos que tinham como destino o afastamento do seu universo de origem, com tudo que este representava de orientação no mundo e de atribuição de significado a este mundo - isto é, cujo destino era tornarem-se diferentes do que deveriam ser. Este afastamento do universo de origem ocorre exatamente através da escolha profissional. É devido à ida dos sujeitos para a universidade que o afastamento se torna ao mesmo tempo necessário e inevitável. A escolha profissional tem, deste modo, o duplo caráter de ser ao mesmo tempo indeterminada e crucial. É através dela que os sujeitos vão "subir na vida" e, ao mesmo tempo, adquirir uma identidade (já que a identidade que poderia ser proporcionada pelo universo de origem é necessariamente abandonada no caminho). E possível então afirmar que a autodefinição profissional contamina a vida toda. A "invenção" de uma ocupação coincide com a "invenção" de si mesmo. Isso é ainda mais verdadeiro no caso da invenção de uma profissão "psi". Esta propicia tanto a possibilidade de uma ocupação rentável (capaz de distanciar os sujeitos de sua origem social) quanto a possibilidade de um encontro consigo mesmo através dessa ocupação rentável.

Ao mesmo tempo, a verdade é que os sujeitos escolhem, dentro das possibilidades oferecidas pelo campo "psi", uma via razoavelmente marginal: uma ocupaçāo que nem nome tinha, cuja implementação e difusão ocorriam nas margens das práticas mais "oficiais" ou institucionalizadas e cuja ideologia contesta fortemente as formas habituais de vida e comportamento. É importante ressaltar, porém, que o sucesso dessas práticas vem justamente de seu caráter marginal e contestatório. Ou seja, são práticas que tiram seu valor exatamente da oposição ao mundo "psi" oficial. Do mesmo modo, é através delas e de seu ideário que os sujeitos pesquisados vão poder transformar sua própria marginalidade de defeito em virtude.

* A psicologia é uma profissão recente, que tem atribuiçôes amplas e genéricas. O psicólogo não tem uma área de atuação definida, nem atribuiçōes precisas. podendo atuar nos mais diversos setores da vida social (escolas, empresas, hospitais, prisões, orfanatos, hospícios, instituições de reabilitação, times de futebol, junto ao poder judiciário e, até mesmo, na "comunidade"). Suas atribuiçōes em cada um desses locais pode variar bastante. Na clínica particular há um sem número de orientaçòes e práticas a serem adotadas. Trata-se, portanto, de uma ocupação com um alto grau de indeterminação. 


\section{O IDEÁRIO DAS TERAPIAS CORPORAIS}

É possível dizer que o ideário das terapias corporais se constrói em torno de três oposições básicas que se recobrem e se interpenetram.

A primeira delas 6 entre indivíduo e sociedade. A sociedade impede o desenvolvimento natural do indivíduo, isto é, ao impedir que ele siga seus impulsos naturais acaba por torná-lo doente. Transformando um pouco o mote rousseauista poderíamos dizer que o indivíduo nasce são, a sociedade é que o corrompe. Numa preleção contra a idéia de "pulsão de morte" em Freud, Reich afirma que "as tendências anti-sociais do insconsciente sāo os produtos de nossa civilização, que reprime as emoções bio-energéticas dadas pela natureza (...) desde o seu nascimento as crianças são condicionadas e adaptadas a uma civilização fundada sobre a repressão das pulsōes secundárias." (Reich, citado em Higgins \& Raphael, 1972:78-79)

Já está colocada aí uma segunda oposição natural/social que reduplica e recobre a primeira. O que a sociedade reprime no indivíduo é seu "cerne biológico", onde se localiza seu desenvolvimento natural. A saúde é o retorno ao que o "homem é naturalmente".

$\mathrm{Na}$ verdade, $\mathrm{o}$ individual parece se confundir com o natural. Tanto a natureza quanto o indivíduo são anteriores à sociedade. A repressão social sobre o indivíduo incide sobre seus impulsos biológicos naturais. A sociedade, aparentemente, não tem qualquer papel positivo na produção desse indivíduo que, deste modo, se constitui basicamente como um ser pré-social, isto é, natural. A concepçāo de indivíduo e de natureza, nesse sentido, se recobrem, e ambas se sustentam numa concep̧̧āo negativa de sociedade.

Outra dualidade que sustenta o ideário das terapias corporais é a que opōe corpo e mente.

Já vimos que o homem nasce na natureza. Esta, enquanto concepção abrangente, engloba o ser humano no reino animal e no cosmos como um todo. Pode-se falar de um nivelamento absoluto entre os diferentes níveis que compõem o universo. Deste ponto de vista, o que distingue o ser humano deixa de ter valor, passando-se a valorizar o que o aproxima de qualquer outro animal. A fala, por exemplo, passa a ser uma característica irrelevante do homem. A mente (ou a razão) não é necessariamente contrária à natureza, mas é englobada pelo binômio natural/biológico. Ao mesmo tempo, o corpo é a sede dos processos naturais - sede das paixões, dos apetites, das sensações e dos afetos, em especial do apetite maior: o sexual. O corpo é, neste sentido, inerentemente biológico/natural.

Os pares de oposição expostos poderiam ser organizados em duas colunas que resumiriam o dualismo presente no ideário das terapias corporais:

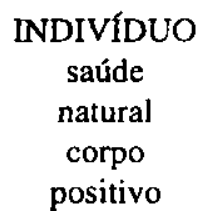

SOCIEDADE
doença
artificial
mente
negativo


Um último aspecto do ideário das terapias corporais a ser examinado não se coloca sob a forma de um dualismo, mas de uma espécie de combinação de contrários que se expressaria, por um lado, num "misticismo fisicalista" e, por outro, num "moralismo sexualista".

A teoria reichiana tem uma concepção inteiramente funcionalista e mecanicista do ser humano. $O$ bom funcionamento do organismo depende de um mecanismo de carga e descarga de energia de origem sexual. O funcionalismo mecanicista do modelo tensão/carga/descarga alia-se ao papel central da sexualidade (genital). Nos dois casos fica patente a concretude do pensamento reichiano. A libido freudiana, por exemplo, transformou-se numa energia mensurável, visível e praticamente palpável (a energia orgônica)".

Ao mesmo tempo é possível observar que esta concretude fisicalista convive com uma boa dose de esoterismo. A concepção de uma energia cósmica, que une todos os seres e coisas do universo - por mais palpável que ela possa ser, não deixa de ter um cunho quase místico, para não dizer religioso. Em seus últimos escritos, Reich fala de uma Energia Vital Cósmica (que corresponderia ao que os homens chamam habitualmente "Deus") e afirmou ter sido capaz de descobrir a origem da vida através dos experimentos realizados em seu laboratório.

Por outro lado, Reich também "concretizou" a concepção fluida e sutil de sexualidade tal como concebida por Freud. Se para este o sexual não se restringia à sexualidade física, para os reichianos sexo é sexo mesmo.

O modo concreto e fisicalista de conceber a sexualidade levou Reich e seus seguidores à idéia de que só é possível curar neuroses (e outros mal-estares) através da liberação sexual de fato. Mais do que isso, a concepção de que a sociedade bloqueia e desvirtua os impulsos naturais levou naturalmente à afirmação da possibilidade de prevenção de neuroses e da infelicidade de um modo geral.

Do mesmo modo que a energia orgônica substitui Deus ${ }^{* *}$, a moralidade tradicional deve ser abandonada em favor de uma moralidade racional e cientificamente determinada. Uma moral determinada pela ciência orgonômica ou, como quer Reich, pela "representação puramente médica das exigências biológicas". Uma espécie de moralidade natural, ditada pela necessidade de carga e descarga dos organismos vivos que, abandonada há tanto tempo, deve ser redescoberta pelos seres humanos.

Neste sentido, os reichianos, com sua curiosa combinação de misticismo e cientificismo mecanicista, apontam para uma utopia: uma sociedade na qual a sexualidade natural (genital) não seria reprimida, as crianças seriam educadas segundo o princípio natural da auto-regulação, e imperaria a democracia do trabalho.

\footnotetext{
* "Energia" é uma noção central que atravessa não somente as terapias corporais, mas as terapias e práticas alternativas como um todo. Luiz Eduardo Soares a designa cono a "moeda cultural do mundo alternativo" (Soares, 1989:129). Trata-se de uma energia cósmica que, complementando a concepção englobante de "natureza", une concretamente os diferentes níveis e fenômenos que compōem o universo. Isto é, aquilo que os homens chamam "Deus" é, na verdade, sua percepção da Energia Vital Cósmica.
} 


\section{TRAJETÓRIA E IDEÁRIO}

É possível ver uma sintonia entre o ideário das terapias corporais e a trajetoria pessoal e profissional do grupo estudado.

Em primeiro lugar, a idéia de que se trata de pessoas que "inventaram a si mesmas", isto $\hat{e}$, pessoas que "se fizeram" contra as possibilidades restritas de sua origem social e também contra as restrições e os obstáculos encontrados em seu caminho: as "cartas marcadas" do meio escolar, as dificuldades de ingressar numa profissão respeitável, a falta de capital cultural e social de origem. $O$ ideário que sustenta sua prática profissional dá sentido a esta trajetória.

Lembremo-nos do que foi exposto no item anterior: o indivíduo existe em oposição à sociedade "repressora" e "limitadora". A possibilidade de "libertação" desses constrangimentos sociais, por outro lado, se dá através do corpo. Através de exercícios, de práticas expressivas, o sujeito constrói um outro corpo para si mesmo. Um corpo que perderá as marcas não só de sua origem de classe, como de pertencimento a qualquer grupo social, na medida em que é o corpo natural reencontrado. Ao se fazerem profissionalmente, portanto, os sujeitos se "refazem" como pessoas e, no mesmo movimento, negam a sociedade que quer relegá-los a uma existência marginal.

A adoção do corpo como instrumento básico de mudança e de "autoconstrução" também significa uma oposição à palavra - o instrumento, por excelência, da racionalidade e da lógica escolar. O fato de o corpo sobrepujar a palavra de novo nos remete à idéia de uma exterioridade social, de um "fazer-se" pelas margens das instâncias tradicionais de consagração escolar, isto é, de consagração pela palavra (ou pelo domínio de um código lingüistico específico).

A combinação entre utopia e pragmatismo, por sua vez. dá sentido à inclinação inscrita na trajetória dos sujeitos.

Dá sentido, inicialmente, à própria "mudança de mundos" operada pelos sujeitos no seu inevitável abandono do universo de origem através da idéia de que "mudar de mundos" nāo apenas é possível, mas necessário e algo intrinsecamente positivo e bom.

Em segundo lugar, fornece parâmetros a sujeitos que têm como indicação somente o "ser diferente". $O$ alto grau de indeterminação implicado nesse tipo de trajetória encontra sua contrapartida no determinismo absoluto de uma moral "natural" que nāo se ancora em qualquer contingência social, sempre passível de relativização.

A trajetória trilhada perde, deste modo, seu caráter de pura possibilidade, sua aleatoriedade, para transformar-se no caminho certeiro que leva o ser humano ao encontro de sua própria essência. A falta de parâmetros é suprida, não com a adoção de parâmetros quaisquer, mas dos parâmetros corretos, imutáveis, porque ancorados numa natureza que nada quer saber de origens ou destinos sociais. 


\section{REFERÊNCIAS BIBLIOGRÁFICAS}

BOURDIEU, P. (1974). "O mercado dos bens simbólicos" em A economia das trocas simb6licas. São Paulo: Perspectiva.

(1979). La Disctinction. Paris: Minuit.

CASTEL, R. (1987). A gestão dos riscos. Rio de Janeiro: Francisco Alves.

HIGGINS, M. \& RAPHAEL C. (Orgs.) (1972). Reich parle de Freud. Paris: Payot.

RUSSO, J. A. (1992). O corpo contra a palavra. Rio de Janeiro, Editora UFRJ.

SALEM, T. (1987). Sobre o casal grávido: incursão em um universo ético. Tese de doutorado, Museu Nacional/UFRJ, Rio de Janeiro.

SOARES, L. E. (1989). "Religioso por natureza: cultura alternativa e misticismo ecológico no Brasil" em Landin, L. (Org.) Tradições religiosas no Brasil. Rio de Janeiro: ISER.

VEL.HO, G. (1975). Nobres e anjos: um estudo de tóxicos e hierarquia. Tese de doutorado, Faculdade de Filosofia, Letras e Ciências Humanas, USP. (1981). Individualismo e Cuitura. Rio de Janeiro: Zahar.

(1986). Subjetividade e Sociedade: uma experiência de geração. Rio de Janeiro: Jorge Zahar Editor. 


\author{
Formato: $16 \times 23 \mathrm{~cm}$ \\ Papel: Pólen Bold $70 \mathrm{~g} / \mathrm{m}^{2}$ (miolo) \\ Cartão Supremo $250 \mathrm{~g} / \mathrm{m}^{2}$ (capa) \\ Fotolitos: Laser vegetal (miolo) \\ Graftipo Gráfica e Editora Ltda. (capa) \\ Reimpressão e acabamento: Imprinta Express Gráfica e Editora Ltda. \\ Rio de Janeiro, junho de 2008 \\ Não encontrando nossos títulos em livrarias, \\ contactar a EDITORA FIOCRUZ: \\ Av. Brasil, 4036 - Térreo-sala 112 - Manguinhos \\ 21040-361 - Rio de Janeiro - RJ \\ Tel.: (21) 3882-9039 e 3882-9007 \\ Telefax: (21) 3882-9006 \\ e-mail: editora@fiocruz.br \\ http://www.fiocruz.br/editora
}

